
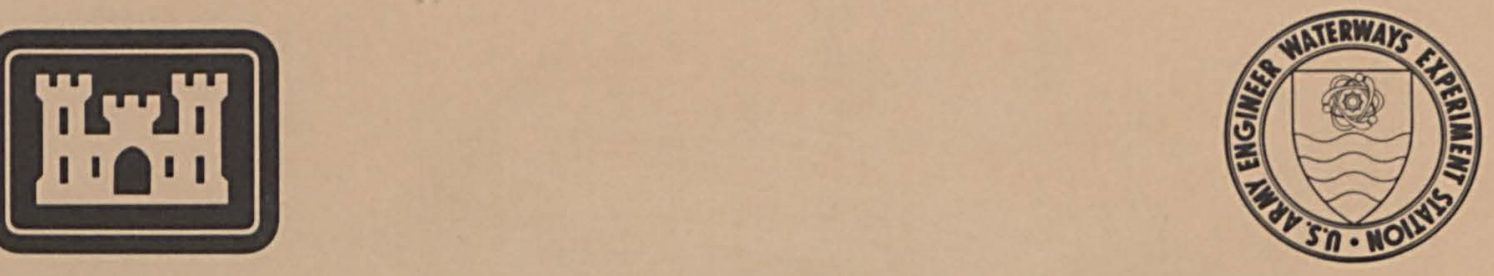

MISCELLANEOUS PAPER SL-82-3

\title{
CONDITION SURVEY OF DEPERE LOCK AND DAM LOWER FOX RIVER, WISCONSIN
}

by

Richard L. Stowe, Joyce C. Ahlvin

Structures Laboratory

U. S. Army Engineer Waterways Experiment Station

P. O. Box 631, Vicksburg, Miss. 39180

June 1982

Final Report

Approved For Public Release; Distribution Unlimited

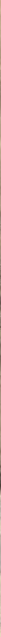

Prepared for U. S. Army Engineer District, Chicago

Chicago, III. 60604 
SECURITY CLASSIFICATION OF THIS PAGE (Thon Dete Entored)

\begin{tabular}{|c|c|}
\hline REPORT DOCUMENTATION PAGE & $\begin{array}{c}\text { READ INSTRUCTIONS } \\
\text { BEFORE COMPLETING FORM }\end{array}$ \\
\hline \begin{tabular}{l|l|} 
1. REPORT NUMBER & 2. GOVT ACCESSION NO. \\
Miscellaneous Paper SL-82-3 &
\end{tabular} & 3. RECIPIENT'S CATALOG NUMBER \\
\hline \multirow{2}{*}{$\begin{array}{l}\text { 4. TITLE (and Subtitı) } \\
\text { CONDITION SURVEY OF DEPERE LOCK AND DAM, } \\
\text { LOWER FOX RIVER, WISCONSIN }\end{array}$} & $\begin{array}{l}\text { 3. TYPE OF REPORT * PERIOD COVERED } \\
\text { FInal report }\end{array}$ \\
\hline & 6. PERFORMING ORG. REPORT NUMBER \\
\hline $\begin{array}{l}\text { 7. AUTHOR(0) } \\
\text { Richard L. Stowe } \\
\text { Joyce C. Ahlvin }\end{array}$ & 8. CONTRACT OR GRANT NUMBER(0) \\
\hline $\begin{array}{l}\text { 9. PERFORMING ORGANIZATION NAME AND ADDRESS } \\
\text { U. S. Army Engineer Waterways Experiment Station } \\
\text { Structures Laboratory } \\
\text { P. O. Box } 631 \text {, Vicksburg, Miss. } 39180\end{array}$ & $\begin{array}{l}\text { 10. PROGAAMELEMENT'PROJECT, TASK } \\
\text { AREA \& WORK UNIT NUMEERS }\end{array}$ \\
\hline \multirow{2}{*}{$\begin{array}{l}\text { 11. CONTROLLING OFFICE NAME AND ADDRESS } \\
\text { U. S. Army Engineer District, Chicago } \\
\text { Chicago, I11. } 60604\end{array}$} & $\begin{array}{l}\text { 12. REPORT DATE } \\
\text { June } 1982\end{array}$ \\
\hline & $\begin{array}{l}\text { 13. NUMBER OF PAGES } \\
122\end{array}$ \\
\hline \multirow[t]{2}{*}{ 14. MONITORING AGENCY NAME a ADDRESS(II dillorent from Controllthe Ollice) } & $\begin{array}{l}\text { 15. SECURITY CLASS. (ol thlo roport) } \\
\text { Unclassifled }\end{array}$ \\
\hline & $\begin{array}{l}\text { 15.. DECLASSIFICATIONTOOWNGRADING } \\
\text { SCHEOULE }\end{array}$ \\
\hline \multicolumn{2}{|l|}{$\begin{array}{l}\text { 16. DISTRIBUTION STATEMENT (ol thle Roport) } \\
\text { Approved for public release; distribution unlimited. }\end{array}$} \\
\hline \multicolumn{2}{|l|}{ 17. DISTRIBUTION STATEMENT (of the obettact entored In Block 20. If difterent from Roport) } \\
\hline \multicolumn{2}{|c|}{$\begin{array}{l}\text { 18. SUPPLEMENTARY NOTES } \\
\text { Available from National Technical Information Service, } 5285 \text { Port Royal Road, } \\
\text { Springfield, Va. } 22151 \text {. } \\
\text { This is CTIAC Report No. } 51 .\end{array}$} \\
\hline \multicolumn{2}{|l|}{$\begin{array}{l}\text { 19. KEY wORDS (Continue on reverce olde Il neceneary end ldontlly by block number) } \\
\text { Concrete dams } \\
\text { Dams--Inspection } \\
\text { DePere Jock and Dam (Wis.) } \\
\text { Lower Fox River (Wis.) }\end{array}$} \\
\hline \multicolumn{2}{|c|}{ 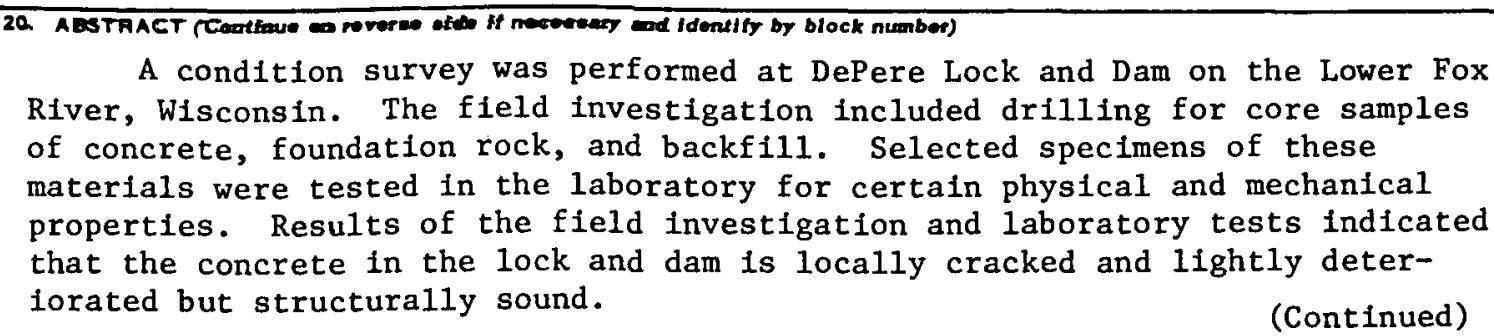 } \\
\hline
\end{tabular}


20. ABSTRACT (Continued)

Cycles of freezing and thawing have caused the concrete deterioration. The lock and dam is founded on competent bedrock. No soft or otherwise weak zones were detected in the bedrock. Soundings should be made to detect any scouring behind the dam. It is suggested that the reinforcing steel in the tainter gate piers, adjacent to the hinge pins, be examined for corrosion. 
The investigation described herein was performed for the U. S. Army Engineer District, Chicago, by the U. S. Army Engineer Waterways Experiment Station (WES). The work was authorized by DA Form 2544, No. NCC-IA-80-58, dated 19 March 1980.

The testing program was accomplished under the direction of Mr. Bryant Mather, Chief of the Structures Laboratory (SL), WES, and Mr. John M. Scanlon, Jr., Chief of the Concrete Technology Division (CTD), SL. The core drilling was conducted by the Geotechnical Laboratory (GL), WES, under the direction of Mr. Mark A. Vispi. Laboratory work in the CTD was done with the assistance of Mr. F. S. Stewart and Mrs. Joyce C. Ahlvin. Mr. R. L. Stowe was Project Leader for the investigation. Mr. Stowe and Mrs. Ahlvin prepared the report.

Funds for publication of the report were provided from those made available for operation of the Concrete Technology Information Analysis Center (CTIAC). This is CTIAC Report No. 51.

Commanders and Directors of WES during the conduct of the investigation and the publication of this report were COL N. P. Conover, CE, and COL T. C. Creel, CE. Technical Director was Mr. F. R. Brown. 
PREFACE

CONVERSION FACTORS, INCH-POUND TO METRIC (SI)

UNITS OF MEASUREMENT. . . . . . . . . . . . . . . . . . . . . 3

PART I: INTRODUCTION . . . . . . . . . . . . . . . . 4

Project Description .. . . . . . . . . . . . . . . . 4

Location of Study Area. . . . . . . . . . . . . . . . 5

Background. . . . . . . . . . . . . . . . . . . 5

Objective . . . . . . . . . . . . . . . . . . 6

Scope . . . . . . . . . . . . . . . . . . . 6

PART II: PRELIMINARY STUDY . . . . . . . . . . . . . . . 7

Review of Records and Drawings. . . . . . . . . . . . 7

Inspection of Lock and Dam. . . . . . . . . . . . . . . . 7

PART III: FOUNDATION EXPLORATION . . . . . . . . . . . . 11

Previous Exploration. . . . . . . . . . . . . . . . . . 11

Current Drilling. . . . . . . . . . . . . . . . . . . 11

Scour Detection... . . . . . . . . . . . . . . . 13

PART IV: GEOLOGICAL CHARACTERISTICS. • . . . . . . . . . . . 14

Geomorphology . . . . . . . . . . . . . . . . . . . 14

Backfilì. . . . . . . . . . . . . . . . . . . . 15

Bedrock Stratigraphy. . . . . . . . . . . . . . . 15

Geologic Cross Section. . . . . . . . . . . . . . . . 16

Structure . . . . . . . . . . . . . . . . . . . 16

PART V: TESTS, TEST RESULTS, AND DISCUSSION. . . . . . . . . . 18

Test Specimens and Test Procedures . . . . . . . . . . 18

Soil Properties... . . . . . . . . . . . . . . . . . . 21

Concrete Test Results and Discussion. . . . . . . . . . . . . 21

Rock Test Results and Discussion. . . . . . . . . . . . . 22

Recommended Design Values for Rock. . . . . . . . . . . . 27

Conclusion and Recommendations. . . . . . . . . . . . . . 28

REFERENCES. . . . . . . . . . . . . . . . . . . . . 29

TABLES $1-6$

PLATES 1-26

APPENDIX A: PHOTOGRAPHS OF LOCK AND DAM

APPENDIX B: DRILLING LOGS 
Inch-pound units of measurement used in this report can be converted to metric (SI) units as follows:

Multiply

feet

feet per second

inches

miles (U. S. statute)

pounds (force) per square inch

pounds (mass) per cubic foot

tons (force) per square foot
By

0.3048

0.3048

0.0254

1.609347

0.006894757

16.01846

0.09576052
To Obtain

metres

metres per second

metres

kilometres

megapascals

kilograms per cubic metre megapascals 


\section{CONDITION SURVEY OF DEPERE LOCK AND DAM}

LOWER FOX RIVER, WISCONSIN

\section{PART I: INTRODUCTION}

\section{Project Description}

1. The following general description of the DePere Lock and Dam is taken from Reference 1.

"The headwaters of the Fox River rise in Columbia County, Wisconsin, and flow in a Northeasterly direction for about 176 miles into Green Bay. The section of the river from Lake Winnebago to Green Bay is generally referred to as the Lower Fox River and is 39 miles long. It has a change in gradient of about 168 feet; channel widths are generally 500 to 1000 feet and minimum channel depths are 9.6 feet below Depere Lock and 6 feet below Menasha Lock. Upper pool El. 586.7 and lower pool El. 576.8 are referred to mean water level at Fathers Point, Quebec I.G.L.D. (1955) (International Great Lakes Datum)."*

The DePere lock is constructed of concrete and was founded directly on dolomite. The lock has a usable lock chamber of 36 by $146 \mathrm{ft}$; ** the lift is $9.9 \mathrm{ft}$ at normal river stage.

3. The DePere dam is of concrete gravity wall design and is keyed into the foundation. The dam consists of a 296.5-ft-long spillway on the right side of the dam and 335-ft-long spillway on the left side of the dam. The mid-portion of the dam is a 355-ft-long sluiceway containing 14 tainter gates. Connected to the left abutment of the U. S. dam is a privately owned overflow spillway about $350 \mathrm{ft}$ long. It is owned and maintained by the Nicolet Paper Corporation. The crest elevation of the spillway section is 587.66 above I.G.L.D. Flashboard construction, approved in 1896, raises the effective crest elevation of the dam from

* All elevations (el) cited herein are in feet referred to I.G.L.D. 1955 (International Great Lakes Datum).

** A table of factors for converting inch-pound units of measurement to metric (SI) units is presented on page 3 . 
586.66 to 587.66 above I.G.L.D. For prior datum planes (Mean Tide New York Datum, 1935), add $1.7 \mathrm{ft}$ to the elevations shown. Typical lock and dam sections are given in Plate 1, which is duplicated from Reference 1.

\section{Location of Study Area}

3. DePere Lock and Dam is located adjacent to the town of DePere, Wisconsin, approximately 7.2 miles from the mouth of the Fox River at Green Bay. A general plan view of the lock and dam is presented in Plate 1.

\section{Background}

4. In March of 1980 the Waterways Experiment Station (WES) was requested by the U. S. Army Engineer District, Chicago (NCC, North Central Division, Chicago), to review a number of documents, References 1 , 2, and 3, and submit a proposal for a condition survey of DePere Lock and Dam. Reference 3 cites a preliminary exploration and testing program which was used as guidance in developing the WES proposal. This is the same exploration and testing program that was used to develop a proposal for the Condition Survey work at Cedars Lock and Dam. The amount of exploration and testing that could be accomplished was governed by available funding.

5. After the proposed work was funded and prior to initiation of the work, District technical staff increased the number of borings. The added borings were drilled and some of the funding allocated for laboratory testing and reporting was diverted to cover the increased drilling cost. The reasons for increasing the number of borings was twofold; first, additional foundation information would be obtained for developing geologic profiles. Secondly, by drilling additional borings with the on-site marine floating plant, crane, etc., cost of mobilization and demobilization would not be incurred for a second drilling effort. Some of the bedrock core from these added borings is preserved at the WES in case further testing is required. 
6. Work on this project was initiated by the Chicago District prior to the 1980 realignment of North Central Division. Work continued under the direction of the Chicago District although the Detroit District is now responsible for the geographical area that includes the Lower Fox River.

\section{Objective}

7. The objectives of this study were to evaluate subsurface conditions, to assess the in-place concrete conditions, to ascertain selected physical properties of concrete and rock, and to evaluate this information in order that design parameters be presented as guidance for a structural stability analysis. In addition, selected physical properties of backfill materials were to be determined. The Detroit District is scheduled to perform the stability analysis.

\section{Scope}

8. The report discusses the drilling effort involved in obtaining samples of soil, concrete, and rock. The physical condition of the inplace exposed concrete is described using a limited amount of information. Selected physical properties of the core samples were determined using standard Corps of Engineers test methods. A limited number of borings were drilled behind the sluiceway dam section for purposes of detecting possible covered scouring. A study was made to consolidate and evaluate engineering information, geologic and boring data, and laboratory test data as they relate to the foundation condition. Available construction and engineering data records were reviewed. 


\section{Review of Records and Drawings}

9. The author made a visit to the Kaukauna Project office to review available engineering and construction drawings in the hope of finding foundation information. Very little information was available. Construction drawings, records, and photographs do not provide much information about the foundation condition. The drawings indicated that the lock and dam was founded on "nearly horizontal limestone rock." The construction photographs verify that nearly horizontal bedrock exists at the site.

10. Right-of-way fly-over photographs of the Lower Fox River were studied for indications of geologic structures such as joint systems and faults. The photographs were helpful in showing the plate-like bedding near the lock and dam. No indications of faulting were detected in the photographs or on topographic maps of the area. NW-NE jointing is visible in the air photographs. To the Kaukauna Project Engineer's knowledge, scour profiles had not been taken at DePere Lock and Dam; in addition, scour holes behind the dam had not been detected nor filled.

\section{Inspection of Lock and Dam}

11. The author and Mr. Steve Running of the Kaukauna Project Office made an inspection of the DePere Lock and Dam site. The main purpose of the inspection was to determine if macroscopic misalignment, settlement, expansion, or contraction of the concrete structures could be detected. Some settlement of masonry bank protection is evident. The settlement occurs upstream of the lock, but in no way affects the operation of the lock. The lock backfill was observed for settlement. The surface condition of the concrete was observed and boring locations assigned. Appendix A presents photographs showing typical conditions of some of the exposed parts of the dam. 
Lock chamber walls

12. No misalignment, settlement, or contraction of the concrete walls was detected. Spalling of the concrete has occurred near the top of several construction joints on both walls; see photo No. 3 , Appendix A, for the worst example. This spalling is not viewed as a problem and could be repaired during routine maintenance. Three vertical cracks in the left wall and one in the right wall extend from the top of the wall to low pool elevation. The cracks probably extend to the base of the wall. The cracks are generally tight, but where open are open from $1 / 8 \mathrm{in.}$ to $1 / 4 \mathrm{in.}$ They appear to pose no problems in terms of the stability of the walls. The tops of the lock walls and the vertical surfaces of the chamber walls are in good condition. (See Photos 1 through 7 in Appendix A.)

Lock embankment

13. The grassed embankment adjacent to both lock walls appears in good condition with local areas showing a little differential settlement in the order of 5 to $9 \mathrm{in}$. The side slopes are about 1 vertical to 2 horizontal. There is no evidence of seepage. (See Photos 8 and 9 (Appendix A).)

Dam, right abutment pier

14. There is no detectable misalignment, settlement, or contraction in the dam structures. Slight expansion of local areas exists in the concrete where freezing and thawing action has occurred. The upper section of the downstream portion of the abutment pier is in good condition. The lower section contains horizontal and vertical cracks outlined with exudation. Some frost damage is evident. As seen in Photo 11 , Appendix A, ground water is seeping along horizontal construction joints resulting in dark stains being deposited on the exposed surface. Spalling of the concrete can be expected with time due to freezing and thawing action along the existing cracks. Until sufficient spalling occurs, repair of the concrete is considered unnecessary.

15. The upstream portion of the abutment pier is in good condition except for an approximate 10-ft-long by 2-ft-deep wedge of concrete at the top of the pier. (See Photos 10 and 12, Appendix A.) A wide 
crack ( $>2 \mathrm{~mm}, 0.08 \mathrm{in.}$ ) can be seen on the top and dam side of the pier. Photo 12 (Appendix A) shows relative movement along the crack. There is no concern about the stability of the pier due to this crack. However, the crack should be measured periodically; if large movement occurs, remedial measures can be taken.

Dam, right spillway

16. The concrete in the foot bridge piers is in generally good condition. Local cracking and exudation is present on the downstream portions of the piers. Light erosion of the downstream face and corners of the piers at the waterline has occurred. The damaged concrete in the piers could be repaired during routine maintenance.

Dam, sluiceway

17. The condition of the concrete in the sluiceway piers is generally good (see Photos 15 through 18, Appendix A). Damage due to freezing and thawing is confined to local areas; the presence of cracks and exudation is evidence of the damage. Small areas of concrete in the piers at and near low pool elevation have been eroded by water and ice action. A few piers have cracks through the piers near the gate hinge pins. Cracks are similarly located in the piers of Cedars Dam on the Lower Fox River. The Chicago District conducted a stability analysis of the cracked concrete piers at Cedars Dam and determined that reinforcement within the piers was effective for gate loads; see Reference 1, Appendix $B$, page B-4. The analysis made for the piers at cedars is applicable for the piers at DePere; they have the same dimensions and reinforcement.

18. It is suggested that a study be made to determine if the reinforcing steel in the sluiceway piers is rusted. Infiltrating water along the cracks could have caused reinforcement to rust. The concrete from around the downstream side of the gate hinge pin could be excavated to examine the reinforcing steel. The damaged concrete in the sluiceway piers appears to pose no problems at this time. Repair of damaged concrete could be handled during routine maintenance. 
Dam, left spillway

19. The concrete in the foot bridge piers is in generally good condition. Local cracking and exudation is present. See Photos 19 through 21, Appendix A. Light erosion is present near the waterline of the piers; see Photo 22, Appendix A. Concrete repair on the noses of several piers is in good condition. Repair of the damaged concrete could be done during routine maintenance.

Dam, left abutment pier

20. The concrete in the middle and the upstream portions of the left abutment pier is in good condition; a few cracks, some exudation, and light erosion is present. The uppermost downstream portion of the pier (see Photo 23, Appendix A) is heavily deteriorated. This portion of the pier is partly submerged and has sustained more freezing and thawing damage than the remaining concrete in the pier because it is critically saturated. Erosion (by water and ice) has also caused some of the damage. Reinforcing steel is exposed at the downstream face of the pier but only at the waterline.

21. It would be wise to check the integrity of the internal concrete in this section of the pier. If the internal concrete is sound, then repair to the external concrete can be made during routine maintenance. Nondestructive tests, such as ultrasonic velocity measurements, could be made to check the soundness of the internal concrete; core borings could likewise be used. 


\section{PART III: FOUNDATION EXPLORATION}

\section{Previous Exploration}

22. Presumab1y borings were taken prior to construction which begun in 1936. However, no information derived from such borings was available for review.

\section{Current Drilling}

23. Drilling equipment consisted of an Acker Toredo Mark II and a Sprage and Henwood skid-mounted rotary drill rig. A Diamond Core Drill Manufacturers Association standard 4-in. by 5-1/2-in. double tube swivel tube core barrel was used with diamond bits to obtain the concrete and bedrock core. Access to the drill holes was by a marine floating plant and for holes on top of structures by crane. Floating plant was supplied by the Kaukauna Project Office. Continuous samples were obtained in all borings. Appropriate size casing was set in the bedrock when necessary to keep a boring open. A Concord portable drill rig was used in drilling horizontal cores.

24. The boring location plan is presented in Plate 2. A summary of boring information is given in Table 1; presented is the type boring, the location by structure, the elevation of the top of boring, the elevation top of rock, the elevation bottom of rock, and the date when the boring was started. The number of borings and boring locations were determined through mutual agreement by the Chicago District and the WES technical staff. Specific boring locations at the lock and dam were assigned by the WES technical staff. The additional borings requested by the District (see explanation, paragraph 5) are presented in the following tabulation: 
No. of

Borings

Location

Direction

2 Dam at either end of spillway, $20 \mathrm{ft}$ into rock

Vertical

1 Backfill through overburden only

1 Lock wall, $20 \mathrm{ft}$ into rock

1 No. 7 sluiceway, pier, $3 \mathrm{ft}$

1 Lock wall, $3 \mathrm{ft}$

1 Right dam abutment, $3 \mathrm{ft}$

Vertical

Vertical

Horizontal

Horizontal

Horizontal

25. Two borings were put through the backfill and into bedrock; one boring was drilled on either side of the lock walls. Bedrock was sampled to a depth of $3.1 \mathrm{ft}$ in the landside boring and to a depth of $30.7 \mathrm{ft}$ in the riverside boring. A piezometer was installed in the riverside boring (D WES E-1-80).* It was set at el 569.8 (piezometer tip). Pertinent piezometer data were presented in Plate 3. Piezometer readings were not taken by the WES drill crew. The deeper borings into bedrock were carried from 21 to $25 \mathrm{ft}$ deep. The shorter scour borings were taken about $5 \mathrm{ft}$ into rock.

26. Boring D WES D $-80^{*}$ was left open while the drill crew remained on site. Water level readings were taken by the lockmaster for a short period of time after the boring was completed. The water level readings are presented in Table 2; the record of water gages is presented in Table 3 .

27. Total footage drilled was $27.9,80.10$, and $181.77 \mathrm{ft}$, respectively, for soil, concrete, and bedrock. All soil, concrete, and bedrock was preserved for possible laboratory testing, the exception being the highly fractured, broken samples. Procedures for preserving and handling the samples are presented in References 4 and 5. Field drilling logs are presented in Appendix B.

28. Core recovery was good in all borings indicating the general good condition of the materials drilled at the lock and dam sites; core recovery averaged 99.5 percent. Drilling water loss was small and restricted to several locations. In boring $\mathrm{Ll}^{*}$ at el 571.9 to 566 , and at

D, DePere; WES, Waterways Experiment Station; E, embankment; D, dam; L, lock; first number represents boring number; 80, year boring made. 
el 562.2, water loss occurred. The zone from el 571.9 to 566.0 contained shale-filled bedding surfaces. Some surfaces were open ( $<2 \mathrm{~mm}, 0.08 \mathrm{in}$.) and stained black. The stained surfaces showed evidence of water solutioning. Slight water loss was detected in boring E1 at el 582.1 .

\section{Scour Detection}

29. It was intended to drill three scour borings behind the sluiceway section of the dam. It was believed that this section of the dam would likely contain several scour areas if any exist. Water passing through the sluice gates could cause scouring of the bedrock downstream of the concrete apron. Two of these borings were completed; one through the concrete apron just upstream of the downstream vertical apron face and one downstream of gate 13. The drilling barge could not be positioned close up behind the right side of the sluiceway or the right spillway; therefore, the third scour boring was placed behind the left spillway. Low water and rocks prevented access close-in-behind the right side of the sluiceway and right spillway. The three borings behind the dam did not reveal any covered scour areas; no evidence of displaced or recently (postdam construction) disoriented rock blocks were detected.

30. Because of the limited number of borings drilled behind the dam and the fact that scour profiles have not been taken, scouring of the bedrock behind the dam could exist. It is suggested that scour profiles, by sounding, be made. Undercutting of the toe of the dam should likewise be studied. 


\section{PART IV: GEOLOGICAL CHARACTERISTICS}

\section{Geomorphology}

31. DePere Lock and Dam is located in Brown County, Wisconsin, in the lowland between Green Bay and Lake Winnebago. This geographic province of Wisconsin is termed the Eastern Ridges and Lowlands and covers an area of 21,000 square miles, including the 7,500 square miles under Green Bay and Lake Michigan. It is bounded on the east by the lowland of Devonian shale now submerged beneath Lake Michigan and on the north by Green Bay. The western border is found along the contact of the Cambrian sandstone with the Lower Magnesian limestone from the Menominee River (Marinette County) to the Wisconsin River (Sauk and Columbia Counties). On the south the region is delineated by the terminal moraine at the edge of the most recent drift sheet and the Rock River below Jonesville.

32. Once much smaller than at present, the Lower Fox River valley was carved to its present size by the glacier. The immense ice sheet advanced southward cutting out the valley of Lake Michigan, while a tongue cut Green Bay Valley to its present dimensions. A medial moraine, the Kettle Range, was formed on the peninsula between Green Bay and Lake Michigan.

33. The retreat of the glacier, coupled with its cutting action, created a depression at Green Bay. The valley floor rises steeply with Lake Winnebago being $166.7 \mathrm{ft}$ above Green Bay. This caused the Wolf and Upper Fox Rivers to change course and flow into the newly formed valley. Evidence of this can be seen in studies of the ancient shore of Lake Michigan by tracing red clay deposits. Lake Winnebago formed more recently by the deposition of glacial drift in the valley.

34. The western slope of the Upper Fox River valley is gentle, while the eastern slope is quite steep. Cliffs on the east are cut through the Cincinnati shales and Niagara dolomite and extend from Green Bay south past Lake Winnebago. The bedrock at the dam is the 
Galena-Platteville dolomite of Ordovician age. The bedrock was assigned to the Galena-Platteville formation, based in part, on information from waterwell logs obtained from the University of Wisconsin Geological and Natural History Survey. All field boring logs identify bedrock as limestone; subsequent petrographic examination shows the bedrock to be dolomite.

\section{Backfil1}

35. The backfill on either side of the lock is considered as construction fill. Profiles of borings E1 and E2 are presented in Plate 4. The backfill consists of a small smount of inorganic clays, gravelly clays, and sandy clays. Beneath the soils is a layer of dolomite cobbles and boulders mixed with clay. The dolomite bedrock underlays the fill. The rock symbols used in the profiles in Plate 4 are for limestone; the symbols should be for dolomite.

\section{Bedrock Stratigraphy}

36. The bedrock beneath DePere Lock and Dam is of the GalenaPlatteville formation of the Champlainian series of the Ordovician system. This formation is between 50 and $150 \mathrm{ft}$ thick in this area, as reported on waterwell logs obtained from the Wisconsin Geological and Natural History Survey.

37. The dolomite is gray to light gray, fine to medium grained, dense, moderately hard to hard, shaley, and fossiliferous in places. A few vugs are present. Bedding is massive. Thin shale beds, laminae, and stringers are part of the rock fabric. The shale is gray-green and quite hard. The shale features range in thickness from $0.01 \mathrm{ft}$ to $0.08 \mathrm{ft}$ and occur continuously to a maximum of $0.5-\mathrm{ft}$ separation. The shale occurs along bedding surfaces.

38. There appear to be two types of bedding surfaces in the core; they are designated Types $A$ and $B$. Type $A$ is irregular with semirounded peaks and valleys. Peak to valley distances range from $1 / 4$ to $3 / 8 \mathrm{in.}$; 
periods are about 2 in. Type A surfaces are tightly interlocked and are the predominant type of bedding surface. Type $B$ is almost planar, yet gently undulating with a few short asperities and steps; Type B bedding surfaces are interlocked. The thin hard shale is found on both types of surfaces. A few stylolites exist in the core. Core breaks occur along the shale features. No soft, weak seams of shale or clay were detected in the core samples.

39. The dolomite contained solution cavities (termed voids on the geologic cross sections) up to $1 / 2 \mathrm{in.}$ in diameter. The cavities were generally filled with calcite crystals. One band of cavities occurred between el 565 and 570 and appeared to be continuous under the lock and the dam.

\section{Geologic Cross Sections}

40. Three geologic cross sections were drawn; sections $A-A^{\prime}, B-B^{\prime}$, and $C_{-} C^{\prime}$ (see Plate 2 for cross section locations). Section $A-A^{\prime}$ (see Plate 5) was drawn perpendicular to the lock axis and includes borings $\mathrm{El}$, E2, and L1. Section B-B' (see Plates 6, 7, and 8) was drawn paralle1 to the dam axis, and section $C_{-} C^{\prime}$ (see Plate 9) was drawn perpendicular to the dam at about its midlength. Section B-B' contains borings D1, D5, D6, D7, and D8, and section $C-C^{\prime}$ contains borings D1, D2, D3, and D4.

\section{Structure}

41. The main structural feature in the bedrock is the nearly horizontal bedding. Hard shale beds, laminae, and stringers occur throughout the bedrock. However, the shale features are intact and intimately joined to the dolomite. The shale features are considered a part of the rock fabric and are not considered individual troublesome units. There is no distinct geologic feature within the bedrock that can be traced between borings. A band of calcite-filled cavities appears to be traceable beneath the lock and dam. 
42. The contact between the concrete and the bedrock core is well bonded in two out of four cases. A loose contact exists in core D7. Shale pieces are embedded in the concrete to a depth of $0.5 \mathrm{ft}$. During construction, a small amount of bedrock was probably left during cleanup prior to placing concrete. Dark staining and solution activity on four bedding surfaces (D2, el 572.2; D3, el 558.4; D7, el 566.3; and L1, el 566.8) indicate movement of water along bedding. Due to the infrequent evidence of solution activity in the bedrock, solutioning of the bedrock is not considered to be a problem at this time due mainly to its apparent limited extent.

43. The extent of jointing in the bedrock could not be determined with the limited work done during this study. A total of six high angle fractures (joints) were observed in the core. The fractures were dipping from 42 to $70 \mathrm{deg}$; in general, the fractures were smooth. Several low angle fractures, $<15 \mathrm{deg}$, were observed. Jointing appears not to be a problem at the lock and dam in terms of stability of the two structures. 
PART V: TESTS, TEST RESULTS, AND DISCUSSION

Test Specimens and Test Procedures

\section{Cores received}

44. Disturbed and undisturbed soil samples were recovered from the two backfill borings. The undisturbed samples were obtained in steel tubes, then pushed into cardboard tubes; 10 cardboard tubes were used. The disturbed samples consist of 11 jars. Core boxes contained the rock core samples recovered from these two borings. Table 4 describes the drill hole number, sample number, type sample, sample depth, and the material description of the soil samples received at the WES.

45. In addition to the soil samples, concrete and rock samples from 12 borings were received at the WES. Shipment of the materials was by government motor freight. All samples were received in good condition, and no sample breakage was detected. Pertinent information concerning the concrete and rock samples is presented in Table 5.

Selection of test specimens

46. Disturbed and undisturbed samples from borings E1-80 and E2-80 were examined and representative samples were chosen for general engineering type testing.

47. A detailed visual examination of core was made in the laboratory to supplement the field boring logs and to assist in the selection of representative test specimens. Concrete specimens were selected for testing based upon physical condition and depth; representative properties throughout the structure could thus be obtained.

48. Three concrete specimens were selected from boring D1; one at the top, middle, and bottom of the boring. These three specimens were deemed representative of the concrete core recovered at the site. Test specimen depths shown in the tables of test results represent the midsection of the test specimen; e.g., el 593.47 is the midpoint of a piece of core with top el being 593.97 and the bottom el being 592.97. Both 6-in. and 4-in.-diameter concrete cores. and 4-in.-diameter rock cores were tested. 
49. An attempt was made to select test specimens to be representative of the bedrock in close proximity to the base of the structure. The test assignment locations can be obtained from appropriate tables of test results as well as from appropriate geologic cross sections.

50. Test specimens were selected for testing concurrent with the detailed logging of core; the logging began one week after core arrived at the laboratory. The test specimens were rewrapped and stored in a moist curing room until time for testing; the moist room is maintained at $73.4 \pm 3 \mathrm{~F}(23 \pm 1.7 \mathrm{C})$.

Laboratory testing program

51. Soil samples. The testing of the soil samples consisted of the following.
a. Gradation Curve.
b. Atterberg Limits Testing.
c. Triaxial, $\overrightarrow{\mathrm{R}}$.

52. Concrete cores. The testing program of the concrete cores consisted of the following tests on representative selected cores.

a. Unft Weight, $\gamma$.

b. Compressive Strength.

c. Water Content, w .

d. Elastic Moduli, E .

e. Poisson's Ratio, $v$.

53. Rock cores. The testing of the bedrock cores consisted of the following tests on representative selected cores. The tests are grouped under either characterization tests or engineering design tests.

a. Characterization tests.

(1) Effective (As Received) and Dry Unit Weight, $\gamma_{m}$ and $\gamma_{d}$.

(2) Water Content, w.

(3) Compressive Strength, $q_{u}$.

b. Engineering design tests.

(1) Elastic Moduli, E.

(2) Poisson's Ratio, $v$.

(3) Triaxial Strength. 
(4) Direct Shear Strength.

(a) Concrete on rock, precut (residual).

(b) Intact (maximum).

(c) Rock on rock, precut (residual).

(d) Cross bed (maximum).

\section{Test procedures}

54. The soil testing was accomplished according to EM 1110-2-1906, Laboratory Soils Testing Manual. The characterization properties tests and the engineering design properties tests were conducted in accordance with the appropriate test method tabulated below:

\begin{tabular}{|c|c|}
\hline Property & Test Method \\
\hline \multicolumn{2}{|l|}{ Characterization } \\
\hline $\begin{array}{l}\text { Effective Unit Weight (As Received), } \gamma_{\mathrm{m}} \\
\text { Dry Unit Weight, } \gamma_{\mathrm{d}} \\
\text { Water Content, w } \\
\text { Compressive Strength, } \mathrm{q}_{\mathrm{u}}\end{array}$ & $\begin{array}{ll}\text { RTM } 109-77 \text { (5) } \\
\text { RTM } 109-77 \\
\text { RTM } 106-77 \\
\text { RTM } 111-77 \text { (ASTM D 2938) }\end{array}$ \\
\hline Engineering Design & \\
\hline $\begin{array}{l}\text { Elastic Modulus, } E \\
\text { Direct Shear Strength } \\
\text { Poisson's Ratio, } v \\
\text { Triaxial Strength }\end{array}$ & $\begin{array}{lll}\text { RTM } & 201-77 \text { (ASTM D 2148) } \\
\text { RTM } & 203-77 \\
\text { RTM } & 201-77 \\
\text { RTM } & 202-77\end{array}$ \\
\hline
\end{tabular}

55. For the compression and triaxial compression test, the specimens were cut with a diamond-blade saw and the cut surfaces were ground flat to 0.001 in.; specimens were checked for parallel ends and the perpendicularity of ends to the axis of the specimen. Electrical resistance strain-gages were used for strain measurements. Two each were used in the axial and horizontal directions. The modulus of elasticity and Poisson's ratio were computed from the strain measurements. Axial specimen load was applied with a 440,000-1bf capacity universal testing machine. Confining pressure during the triaxial tests was applied using an electro-hydraulic pump. 


\section{Soil Properties}

56. All of the laboratory test data from soil samples are presented in Plates 10 through 18 . The data consist of the following:

a. Boring E1-80.

(1) Three Atterburg Limits, classification (sieve analysis).

(2) One $\overline{\mathrm{R}}$ triaxial test.

b. Boring E2-80.

Two $\bar{R}$ triaxial test.

This report does not present an interpretation or recommended design parameters for the materials in the backfill because of various unknowns. We don't know what type of slope stability analysis will be used by the district, where the failure plane will be assumed within the backfill, and whether the bedrock will be incorporated in the analysis.

\section{Concrete Test Results and Discussion}

57. The following comments pertain to the condition of the concrete in the dam. These comments are the results of examination of the core recovered at the dam. The condition of the exposed concrete is discussed in Part II of this report. The concrete characterization and engineering design test results are presented in Table 6.

58. The concrete recovered from borings is nonair-entrained. It is light gray-brown, hard, dense, contains crushed and natural carbonate aggregate $1 \mathrm{in}$, in maximum size. Large aggregate is rounded to angular. The concrete contains occasional entrapped air voids about $1 / 4 \mathrm{in}$. in size and is well consolidated. A few honeycombed areas occur, but they do not affect the structural integrity of the concrete. Minor amounts of white reaction products were found throughout the concrete. The white reaction material probably resulted from alkali-silica reaction and is an alkali carbonate. At this time the concrete is not adversely affected by the process producing the white reaction product, nor will it be in the near future. The concrete in the dam is structurally sound and should serve its intended purpose; the exceptions are those local 
exterior areas where frost-damaged concrete exist. The author believes that there is no reason to immediately repair the cracked or frostdamaged concrete in the dam. Repair of these damaged areas could be performed during regular maintenance periods.

59. The average physical properties of the concrete are tabulated below with the standard deviation. Stress versus strain curves are presented in Plate 19 for the three concrete specimens tested:

\begin{tabular}{|c|c|c|c|}
\hline Test & $\begin{array}{c}\text { Average } \\
\text { Value }\end{array}$ & $\begin{array}{l}\text { Standard } \\
\text { Deviation }\end{array}$ & $\begin{array}{c}\text { No. } \\
\text { Specimens }\end{array}$ \\
\hline $\begin{array}{l}\text { Wet Unit Weight, pcf } \\
\text { Water Content, } \% \\
\text { Compressive Strength, psi } \\
\text { Modulus of Elasticity, x } 10^{6} \text { psi } \\
\text { Poisson's ratio }\end{array}$ & $\begin{array}{c}152.7 \\
4.6 \\
8540 \\
6.92 \\
0.20\end{array}$ & $\begin{array}{l}0.98 \\
0.15 \\
1260 \\
0.7 \\
0.08\end{array}$ & $\begin{array}{l}3 \\
3 \\
3 \\
3 \\
3\end{array}$ \\
\hline
\end{tabular}

60. The physical properties of the concrete are characteristic of good quality concrete. The standard deviations are considered small and indicative of uniform concrete properties for the small number of specimens tested.

Rock Test Results and Discussion

61. The results of the characterization properties tests are presented in Table 6 for the bedrock. Stress versus strain curves are presented in P1ates 20 and 21 . The following tabulation presents a summary of the average characterization properties and selected statistics for the bedrock.

\section{Test}

Effective Unit Weight, pcf

Dry Unit Weight, pcf

Water Content, \%

Compressive Strength, psi

Modulus of Elasticity, x $10^{6}$ psi

Poisson's Ratio

Shear Modulus, $x 10^{6} \mathrm{psi}^{*}$
Average

Value

170.3

169.1

0.7

21,070

8.22

0.23

3.34
Standard

Deviation

2.93

3.14

0.37

7590

1.73

0.05
No. Specimens

6

6

6

6

6

6

6 
62. The tabulated rock properties are reasonable for the high quality bedrock beneath the DePere Lock and Dam. The relatively low standard deviations for the different tests indicate consistency of the samples tested with the exception of the compressive strengths. The standard deviation is indicative of a wide range in strength; the low strength is 14,260 psi and the high strength 30,640 psi.

Maximum and residual

shear stress criteria

63. The following discussion of shear stress criteria is taken from Zeiglar (6) and is followed in this report.

64. Designers are commonly interested in the maximum available shear strength. The maximum shear stress points are identified as $\tau_{\max }$ in Figure 1. The maximum shear stress usually corresponds to the peak of the shear stress versus displacement plot (curve a of Figure 1); however, some confusion may arise where strain-hardening is encountered. When strain-hardening occurs, an initial peak usually occurs at a relatively small displacement, followed by an increase in shear stress to a value greater than the initial peak. When this happens, the first peak is termed the maximum shear stress corresponding to initial failure and the latter is the ultimate shear stress.

65. If the residual shear strength is to be determined from the intact specimens, then displacement is continued until the shear stress approaches the horizontal asymtotic value of residual shear stress $\tau_{R}$ (curve a of Figure 1). When the zone tested exhibits only a residual shear strength, curve $b$ of Figure 1 may be obtained. In such cases, the maximum shear stress attained is the residual shear strength; precut specimens exhibit this type of curve. The shear strength obtained from precut specimens approaches the residual shear strength.

Maximum and residual shear strengths

66. Two types of direct shear tests were conducted to determine maximum strength of intact specimens and sliding friction properties of discontinuous specimens. Maximum strength was measured for intact dolomite parallel to and across bedding planes. Sliding friction properties were measured for specimens along precut surfaces, including concrete on 


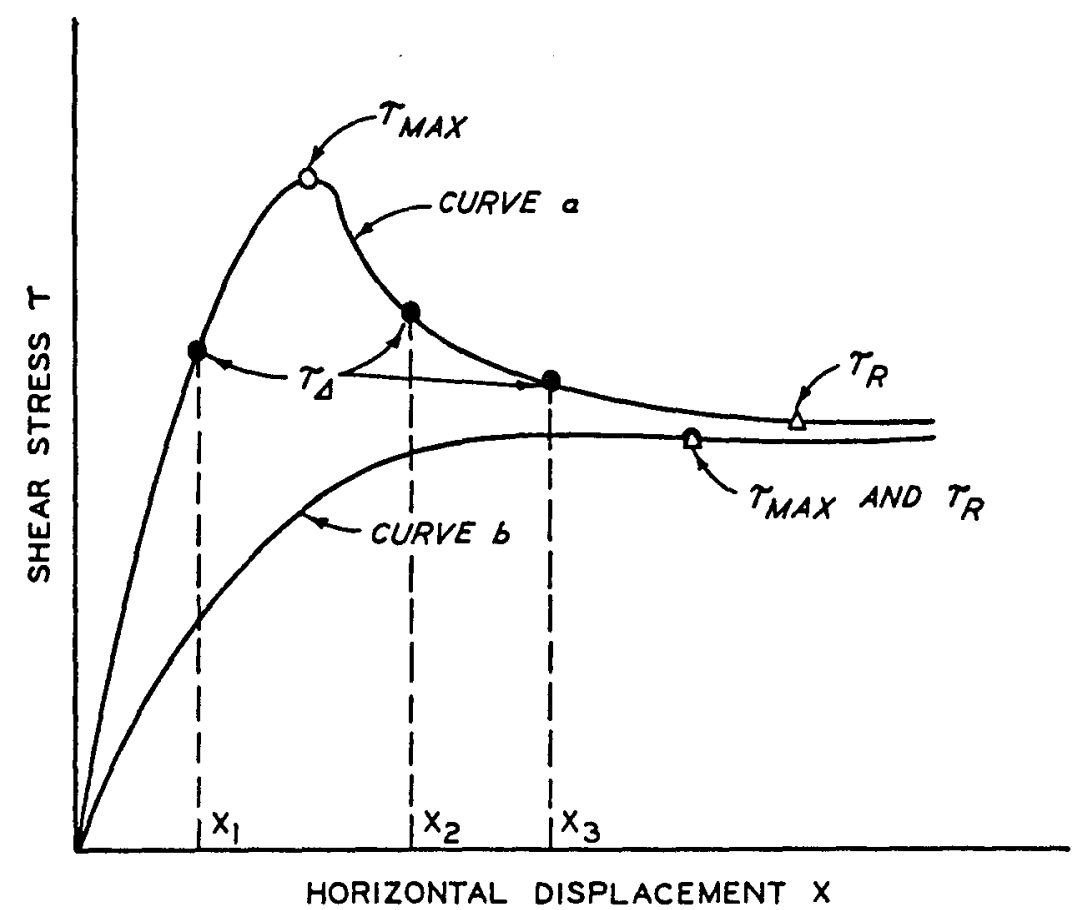

Figure 1. Maximum and residual shear stress and displacement failure criteria, after Zeiglar. 6

rock and rock on rock. The direct shear test results of intact specimens are presented in Plates 22 and 23; shear stress values, load-deformation curves, and typical normal versus shear deformation curves are presented. The direct shear test results from the discontinuous specimens tested as precut specimens are presented in Plates 24 and 25. Maximum and residual strength failure envelopes for the intact and discontinuous specimens are presented in Figure 2 .

67. The foundation rock at the DePere Lock and Dam is the same as the foundation rock at the Cedars Lock and Dam; ${ }^{7}$ within the same geologic formation downsection by about $100 \mathrm{ft}$; the lithology, texture, bedding planes, density, and average compressive strength are considered the same. The foundation core at both sites did not contain any potential weak zones (soft weak clay or shale seams) as mentioned previously. For these reasons, plus the reduced funding for laboratory testing (see para 5), the intact direct shear tests on the Type B bedding surfaces were not performed. The direct shear test results, from the Cedars Lock 


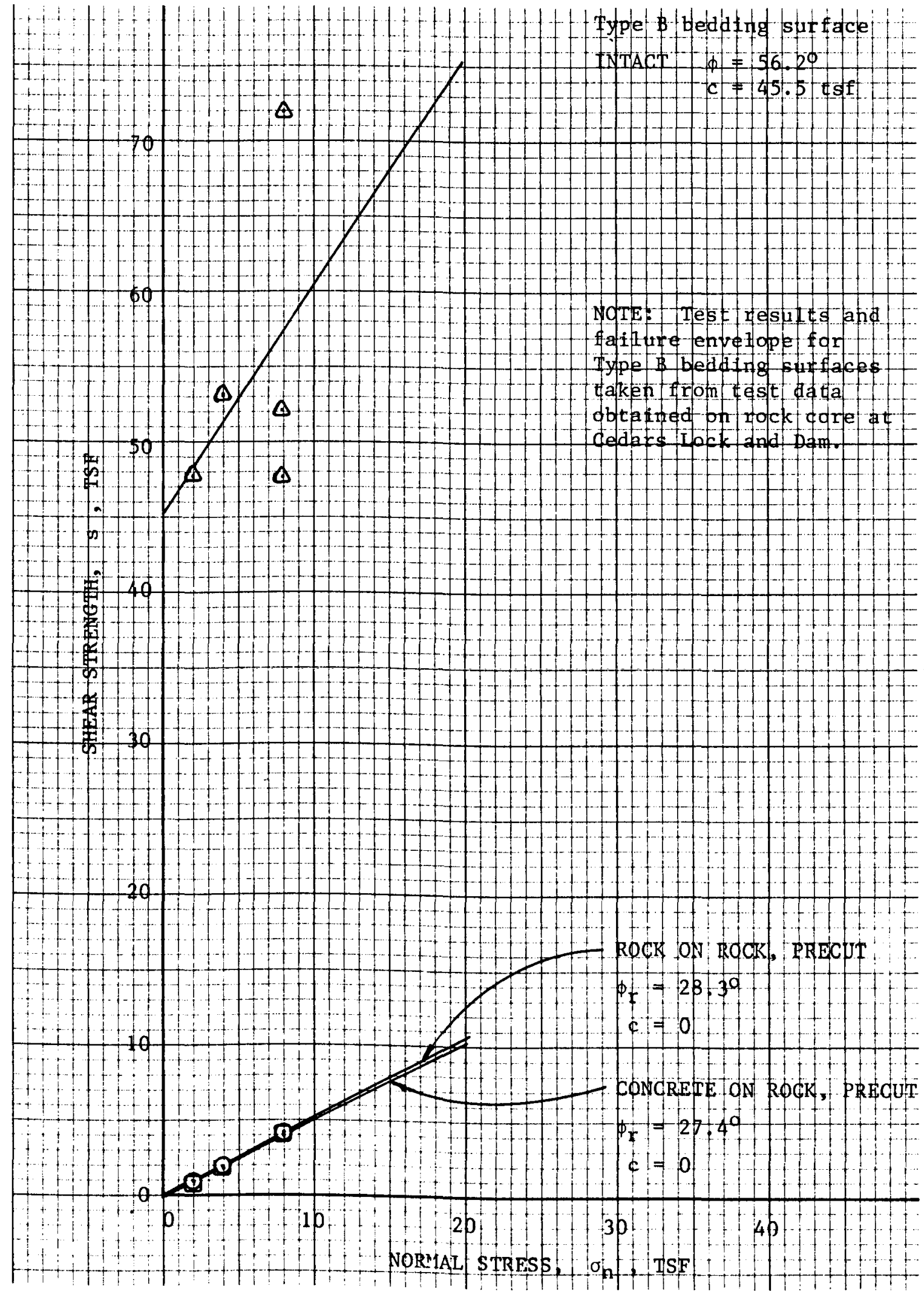

Figure 2. Direct shear test results, maximum and residual shear strength failure envelopes. 
and Dam core, that contained the Type $B$ bedding, are presented in this report (see Plate 26). The intact shear strength values from the Cedars' core can reasonably be used for the Type $B$ bedding surfaces found in the foundation rock at DePere Lock and Dam.

68. The shear strength parameters for the Type A bedding surfaces obtained on the DePere core are $\phi=78.5^{\circ}$ and $c=70 \mathrm{tsf}$. The phi value compares well with the phi measured from the Cedars' core, which is $81 \mathrm{deg}$. The shear strength parameters for the Type B surfaces are $\phi=56.2 \mathrm{deg}$ and $\mathrm{c}=45.6 \mathrm{tsf}$. Specimens with both types of bedding surfaces had good shear breaks. The shear gap between the shear blocks was $1 / 16 \mathrm{in}$. The specimens sheared within this gap or within $\pm 3 / 16 \mathrm{in}$. of the gap.

69. Almost all shear failures of the intact specimens tested parallel to bedding were by breaking through the hard, thin shale features. Only a few asperities on the Type A surfaces sheared at the base. None of the asperities on the Type $B$ bedding surfaces were sheared. As shear deformation occurred, dilation began and one-half of the specimen rode up over the other. Attempts were not made to determine residual frictIon from the intact specimens. Precut rock specimens were used to determine the residual strength values. The sliding friction values for precut dolomite are $\phi=28.3 \mathrm{deg}$ and $\mathrm{c}=0$.

70. The interlocked bedding plane asperities and the inability to trace continuous bedding plane discontinuities across the site imply that any large-scale failure would involve substantial shearing of intact rock. Therefore, the residual value is not expected to control sliding beneath the lock or dam.

71. After considering (a) the interlocking nature of the bedding surfaces, (b) the intimate and intact shale-dolomite rock fabric, and (c) because previously failed seams or indications of past horizontal movement in the bedrock were not observed, it is thought that peak shearing resistances of the shale features associated with the most nearly planar bedding surfaces (Type B) would control sliding. These peak shear strengths are recommended for computing stability, i.e., $\phi=$ $56 \mathrm{deg}$ and $\mathrm{c}=45.6 \mathrm{tsf}$. 
72. Cross-bed shear tests were conducted (see Plate 23). The test results indicate a high phi and cohesion; $\phi=72 \mathrm{deg}$ and $c=$ 63 tsf, which is close to the shear strengths obtained on the intact Type A bedding surfaces ( $\phi=78.5 \mathrm{deg}$ and $c=70 \mathrm{tsf}$ ). To be conservative, it is suggested that the intact shear strengths measured for the Type $B$ bedding surfaces, $\phi=56.2 \mathrm{deg}$ and $c=45.6 \mathrm{tsf}$, be used for cross-bed shear computations. Stagg and Zienkiewic ${ }^{8}$ state that:

\footnotetext{
"When the directions of loading are such that the potential failure surfaces must cut across the structural features, the shear strength will approach that of the intact rock material."
}

Structural feastures, as mentioned in the quote from Stagg and Zienkiewicz, typically include joints, shear zones, and faults. At this site, the ubiquity of tightly interlocked asperities on the bedding. planes justifies their inclusion in the class of "structural features" across which shear must occur.

\section{Recommended Design Values}

73. Design should consider the rock and the bedrock structural characteristics described herein. Guidance is presented in the following tabulation as to proper choice of design parameters:

\section{Rock Property}

Effective Unit Weight, $1 \mathrm{~b} / \mathrm{ft}^{3}$

Dry Unit Weight, $1 \mathrm{~b} / \mathrm{ft}^{3}$

Compressive Strength, psi

Shear Strength

Intact, Type $B$ bedding

Precut, rock on rock

Precut, concrete on rock

Cross bedded

Modulus of Elasticity, $\times 10^{6}$ psi

Poisson's Ratio

Shear Modulus, $x 10^{6}$ psi

\section{Do1omite}

170.3

169.1

21,070

$\phi=56.2^{\circ}$

$c=45.6 \mathrm{tsf}$

$\phi_{\mathrm{r}}=28.3^{\circ}$

$\mathrm{c}=0$

$\phi_{\mathrm{r}}=27.4^{\circ}$

$\mathrm{c}=0$

$\phi=56.2^{\circ}$

$c=45.6 \mathrm{tsf}$

8.22

0.23

3.34 
Conclusions and Recommendations

74. Based upon a visual inspection of the lock and dam, core samples, and laboratory test results, the following conclusions seem warranted:

a. The concrete in the lock appears sound and has held up well in the severe winter conditions considering it is nonair entrained; it should continue to serve its original intended purpose.

b. The concrete in the lock and dam is locally cracked and lightly deteriorated. The deterioration is due to cycles of freezing and thawing. Several tainter gate piers have cracks adjacent to the hinge pins that go through the piers. The cause of these cracks is not postulated. The concrete in the dam is structurally sound and should continue to serve its originally intended purpose.

c. The lock and dam is founded on competent bedrock which contains a minimal number of discontinuities. Jointing is minimal. Shale features occur along interlocked bedding planes; they are thin and considered as part of the rock fabric. No soft or otherwise weak zones were detected in the bedrock.

d. It is our opinion that no significant scour has occurred behind the dam. Sounding behind the dam should be made to establish a scouring datum base.

e. We suggest that a study be conducted to ascertain if the reinforcing steel in the downstream portion of the tainter gate piers is badly corroded. An area around one of the hinge pins could be excavated for this purpose. Cracks in the piers near the hinge pins could be sealed to stop water from entering the concrete and possible corroding the reinforcing steel. 


\section{REFERENCES}

1. U. S. Army Engineer District, Chicago, "Periodic Inspection Report No. 1," DePere Lock and Dam, Lower Fox River, Wisconsin, Nov 1976.

2. Letter, NCCED-DC, dated 26 Dec 1979, subject "Periodic Inspection and Continuing Evaluation of Completed Civil Works Structures - Lower Fox River, Wisconsin, Appleton Locks and Dams;" attached to this letter is NCDED-T (26 Dec 79) 1st Ind, subject as above, and NCCED-DC (26 Dec 79) 2d Ind, subject as above.

3. Letter, NCCED-DC, dated 29 Nov 1976, subject "Periodic Inspection and Continuing Evaluation of Completed Civil Works Structures - Lower Fox River, Wisconsin, Appleton and DePere Locks and Dams;" attached to this letter is NCDED-T (29 Nov 76) 1st Ind, subject as above.

4. U. S. Army, Office, Chief of Engineers, "Engineering and Design: Soil Sampling," EM 1110-2-1907, 31 Mar 72, U. S. Government Printing Office, Washington, D. C.

5. U. S. Army Engineer Waterways Experiment Station, CE, "Rock Testing Handbook," Test Standards - 1980, Vicksburg, Miss., Aug 1980.

6. Zeigler, T. W., "In Situ Tests for the Determination of Rock Mass Shear Strength," TR No. S-72-12, Nov 1972, U. S. Army Engineer Waterways Experiment Station, CE, Vicksburg, Miss. (AD 752 422)

7. Letter Report, subject, "Condition Survey of Cedars Lock and Dam, Lower Fox Kiver, Wisconsin, "Apr 1981, sent to U. S. Army Engineer District, Chicago.

8. Stagg, K. G. and Zienkiewicz, 0. C., Rock Mechanics in Engineering Practice, John Wiley and Sons, London, 1968, p 46. 
Table 1

Borings, Locations, Elevations, and Starting Date of Borings

DePere Lock and Dam, Lower Fox River

\begin{tabular}{|c|c|c|c|c|c|c|c|}
\hline Boring No. & $\begin{array}{l}\text { Type of } \\
\text { Boring }\end{array}$ & Location & $\begin{array}{c}\text { E1 Top } \\
\text { of Boring } \\
\mathrm{ft}\end{array}$ & $\begin{array}{l}\text { E1 Top } \\
\text { of Rock } \\
\mathrm{ft} \\
\end{array}$ & $\begin{array}{l}\text { E1 Bottom } \\
\text { of Boring } \\
\mathrm{ft}\end{array}$ & $\begin{array}{l}\text { Horizontal } \\
\text { Boring, Depth } \\
\mathrm{ft}\end{array}$ & Start Date \\
\hline D WES Ll-80 & & Right Lock Wall & 591.80 & 571.20 & 550.70 & & 21 July 1980 \\
\hline D WES L2-80 & & Right Lock Wall & 587.80 & - & 587.80 & 3.15 & 24 July 1980 \\
\hline D WES E $1-80$ & & Backfil1, LLW & 591.80 & 578.00 & 547.30 & & 1 July 1980 \\
\hline D WES E2-80 & & Backfill, RLW & 590.40 & 576.30 & 573.20 & & 25 Ju1y 1980 \\
\hline D WES D1-80 & & Sluiceway Pier 7 & 593.97 & 574.92 & 552.97 & & 11 July 1980 \\
\hline D WES D2-80 & & US of Sluiceway Pier 7 & 577.47 & 577.47 & 556.57 & & 7 July 1980 \\
\hline D WES D3-80 & 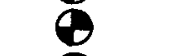 & DS of Sluiceway Pier 7 & 575.23 & 575.23 & 553.83 & & 4 July 1980 \\
\hline D WES D4-80 & & $\begin{array}{l}\text { US of DS Face, Next to } \\
\text { Pier } 7\end{array}$ & 576.50 & 575.30 & 571.33 & & 10 July 1980 \\
\hline D WES D5-80 & $\theta$ & DS of Sluiceway Gate 13 & 572.80 & 572.80 & 567.34 & & 9 July 1980 \\
\hline D WES D6-80 & & $\begin{array}{l}\text { DS, Left Spillway, between } \\
\text { Piers } 9 \text { and } 10\end{array}$ & 576.30 & 576.30 & 570.81 & & 9 July 1980 \\
\hline D WES D7-80 & $\theta$ & Right Spillway Pier 1 & 591.80 & 576.60 & 551.80 & & 16 July 1980 \\
\hline D WES D8-80 & & Left Spillway Pier 10 & 591.80 & 576.70 & 553.20 & & 18 July 1980 \\
\hline D WES D9-80 & & Sluiceway Pier 7 & 584.13 & - & 584.13 & 2.85 & 23 July 1980 \\
\hline D WES D10-80 & & Right Abutment Pier & 584.30 & -- & 584.30 & 2.95 & 23 July 1980 \\
\hline
\end{tabular}

8 Vertical 4-in. core hole.

Horizontal 4-in. core hole.

Combined drive sample and core.

Combined drive sample and core with piezometer installed.

LLW, Landside lock wall.

RLW, Riverside lock wall.

US Upstream.

DS Downstream. 
Table 2

Water Level Readings in Boring No. DWES D1-80

at DePere Dam, Sluiceway Pier \#7

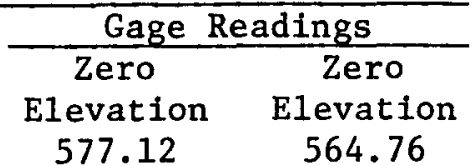

\begin{tabular}{|c|c|c|c|c|c|}
\hline Date & Time & Reading & Elevation* & Upper Pool & Lower Pool \\
\hline $8-19-80$ & 11:00 a.m. & 13.59 & 580.38 & 10.4 & 15.1 \\
\hline $8-20-80$ & $8: 00 \mathrm{a} \cdot \mathrm{m}$. & 13.63 & 580.34 & 10.4 & 15.4 \\
\hline $8-21-80$ & $8: 00$ a.m. & 13.53 & 580.44 & 10.4 & 15.4 \\
\hline $8-22-80$ & $8: 00$ a.m. & 13.66 & 580.31 & 10.4 & 15.5 \\
\hline $8-23-80$ & $8: 00$ a.m. & 13.35 & 580.62 & 10.3 & 15.5 \\
\hline $8-24-80$ & $8: 00$ a.m. & 13.22 & 580.75 & 10.5 & 15.8 \\
\hline $8-25-80$ & $8: 00$ a.m. & 13.12 & 580.85 & 10.5 & 15.9 \\
\hline $8-26-80$ & $8: 00$ a.m. & 13.25 & 580.72 & 10.6 & 15.7 \\
\hline
\end{tabular}

* Elevation of water in boring hole measured from top of boring hole with elevation of 593.97 I.G.L.D. 
Table 3

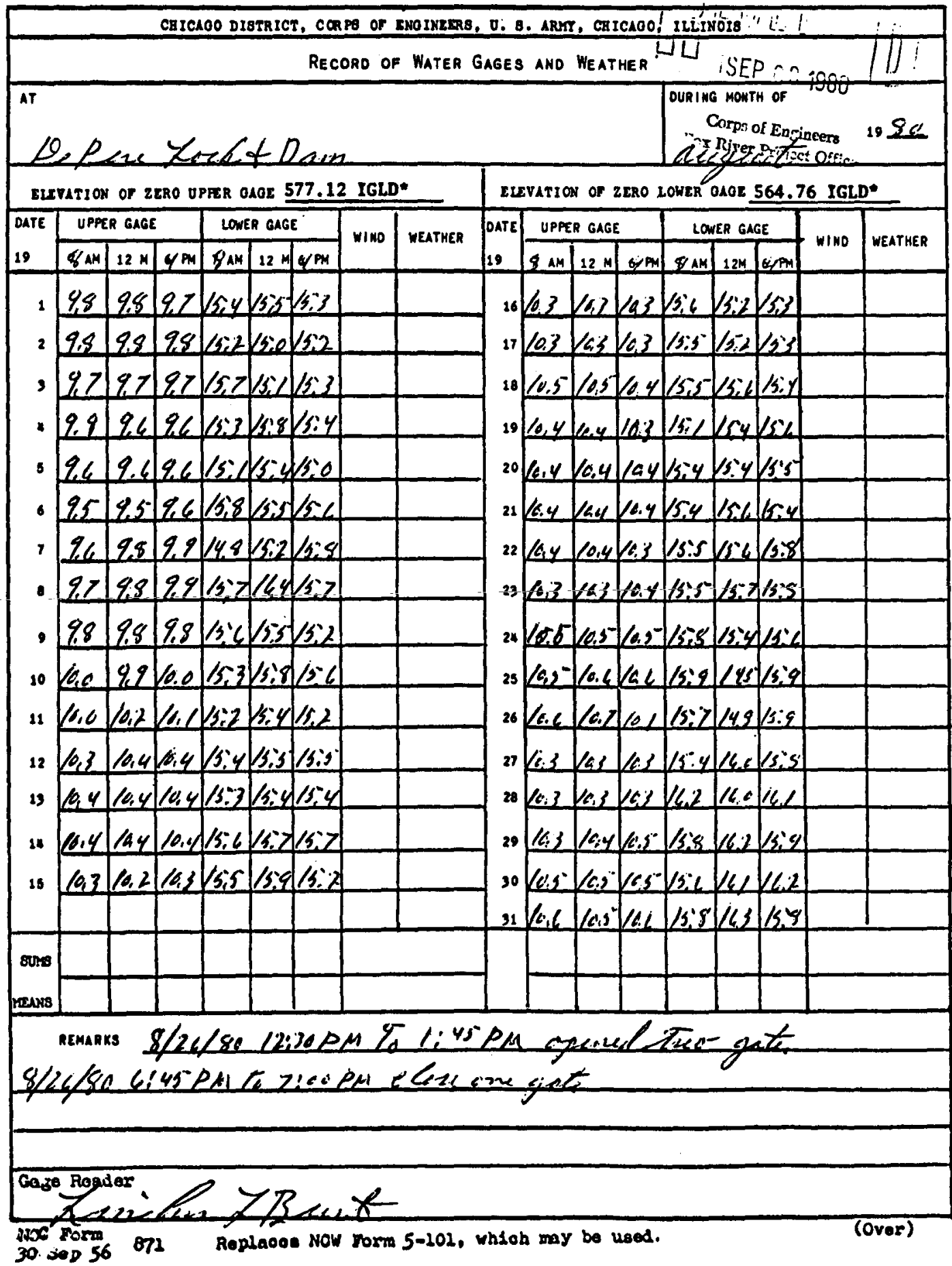


Table 4

So11 Samples Received, DePere Lock and Dam, Lower Fox River

\begin{tabular}{|c|c|c|c|c|c|c|}
\hline $\begin{array}{c}\text { Date } \\
\text { Received }\end{array}$ & Boring No. & $\begin{array}{l}\text { Sample } \\
\text { No. } \\
\end{array}$ & Type Sample & & $\begin{array}{c}\text { Sample } \\
\text { Depth, ft }\end{array}$ & Field Nomenclature \\
\hline $\begin{array}{l}15 \text { Sep } 80 \\
15 \text { Sep } 80 \\
15 \text { Sep } 80 \\
15 \text { Sep } 80 \\
15 \text { Sep } 80 \\
15 \text { Sep } 80 \\
15 \text { Sep } 80 \\
15 \text { Sep } 80 \\
15 \text { Sep } 80 \\
15 \text { Sep } 80 \\
15 \text { Sep } 80 \\
15 \text { Sep } 80 \\
15 \text { Sep } 80 \\
15 \text { Sep } 80 \\
15 \text { Sep } 80 \\
15 \text { Sep } 80 \\
15 \text { Sep } 80 \\
15 \text { Sep } 80 \\
15 \text { Sep } 80 \\
15 \text { Sep } 80 \\
15 \text { Sep } 80 \\
15 \text { Sep } 80 \\
15 \text { Sep } 80 \\
15 \text { Sep } 80 \\
15 \text { Sep } 80 \\
15 \text { Sep } 80 \\
15 \text { Sep } 80\end{array}$ & 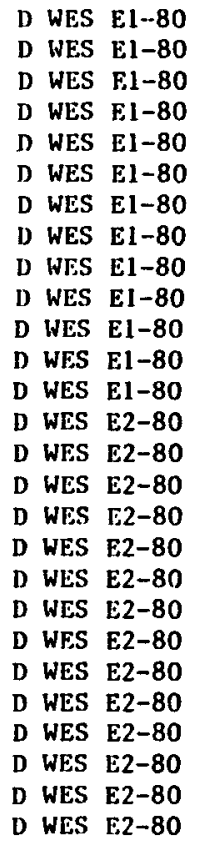 & $\begin{array}{l}1 \mathrm{~A} \\
1 \\
2 \mathrm{~A} \\
2 \\
3 \mathrm{~A} \\
3 \\
4 \mathrm{~A} \\
4 \\
5 \mathrm{~A} \\
5 \\
6 \mathrm{~A} \\
7 \\
8 \\
1 \mathrm{~A} \\
1 \mathrm{~B} \\
2 \mathrm{~A} \\
2 \mathrm{~B} \\
3 \mathrm{~A} \\
3 \mathrm{~B} \\
4 \mathrm{~A} \\
4 \mathrm{~B} \\
5 \mathrm{~B} \\
5 \mathrm{C} \\
6 \\
6 \\
7 \mathrm{~A} \\
7 \mathrm{~B}\end{array}$ & 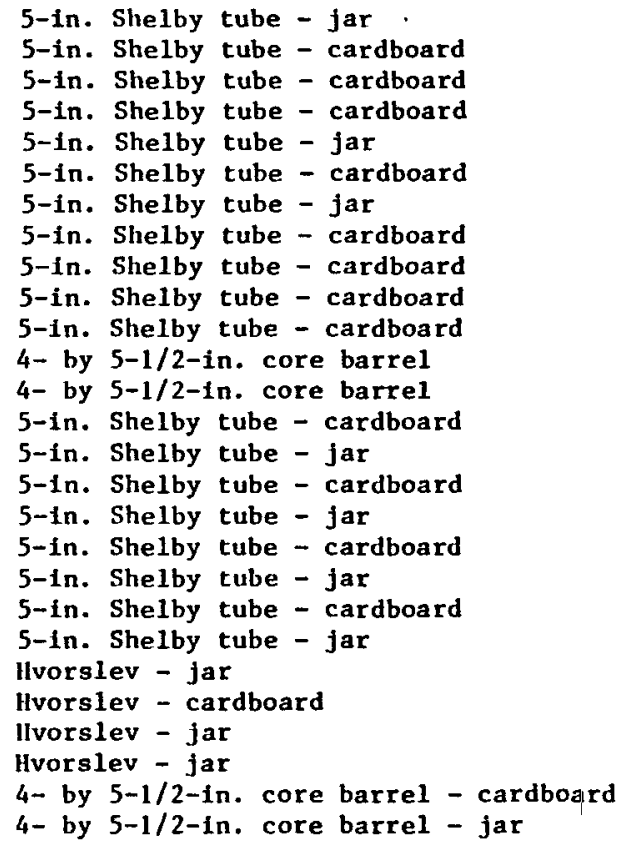 & 10 & $\begin{array}{l}0.0-0.3 \\
0.3-0.85 \\
0.85-1.2 \\
1.2-2.1 \\
3.0-3.2 \\
3.2-4.0 \\
5.0-5.1 \\
5.1-5.9 \\
5.9-6.0 \\
6.9-6.75 \\
7.5-7.7 \\
8.1-8.7 \\
12.6-13.8 \\
0.0-0.85 \\
0.85-0.9 \\
0.9-1.85 \\
1.85-1.9 \\
0.0-0.45 \\
0.45-0.59 \\
0.5-1.55 \\
1.50-1.55 \\
2.5-2.7 \\
2.7-4.0 \\
4.0-4.2 \\
4.5-4.85 \\
4.85-6.9 \\
5.85-6.9\end{array}$ & $\begin{array}{l}\text { Silty clay (CL), brown, Tr rt } \\
\text { Silty clay (CL), brown, w/Tr rt } \\
\text { Silty clay (CL), brown, w/Tr rt } \\
\text { Silty clay (CL), brown, w/Tr rt } \\
\text { Silty clay (CL), brown, w/1/2-in. gravel } \\
\text { Silty clay (CL), brown, w/1/2-1n. gravel } \\
\text { Clay (CL) w/gravel, brown, w/1/2-1n. grave1 } \\
\text { Clay (CL) w/gravel, brown, w/1/2-In. grave } \\
\text { Clay (CL) w/gravel, brown, w/1-1n. gravel } \\
\text { Clay (CL) w/Tr F SS, reddish brown } \\
\text { Dolomite w/clay, gray brown } \\
\text { Dolomite - gravel w/clay binder - boulder } \\
\text { Dolomfte - gravel w/clay, gray } \\
\text { Organic and clay } \\
\text { Clay, brown } \\
\text { Clay goft } \\
\text { Clay soft } \\
\text { Organic and clay. Hole offset } 1 \text { ft. } \\
\text { Clay, brown } \\
\text { Clay, brown } \\
\text { Clay, brown } \\
\text { Clay, brown Tr medlum gravel } \\
\text { Clay, brown Tr medium gravel } \\
\text { Clay, brown Tr medium gravel } \\
\text { G clay } \\
\text { G clay } \\
\text { G clay }\end{array}$ \\
\hline
\end{tabular}


Table 5

Concrete and Rock Samples Recelved at WES, DePere Lock and Dam, Lower Fox River

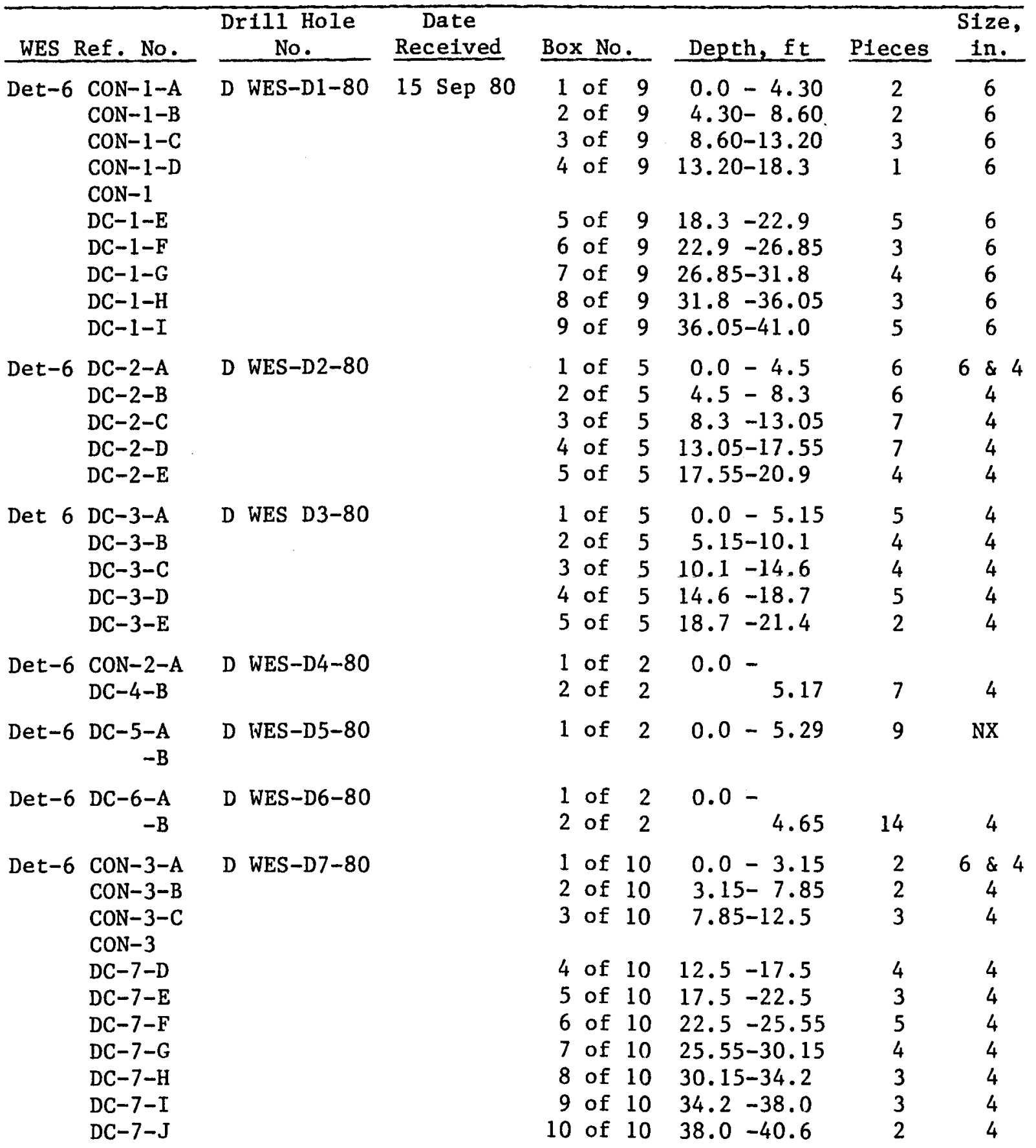


Table 5 (Concluded)

\begin{tabular}{|c|c|c|c|c|c|c|c|c|}
\hline WES & Ref. No. & $\begin{array}{c}\text { Drill Hole } \\
\text { No. } \\
\end{array}$ & $\begin{array}{c}\text { Date } \\
\text { Received }\end{array}$ & Box No & & Depth, ft & Pieces & $\begin{array}{c}\text { Size, } \\
\text { in. }\end{array}$ \\
\hline Det -6 & $\begin{array}{l}\text { CON-4-A } \\
\text { CON-4-B } \\
\text { CON-4-C } \\
\text { CON-4-D } \\
\text { CON-4 } \\
\text { DC-8-E } \\
\text { DC-8-F } \\
\text { DC-8-G } \\
\text { DC-8-H } \\
\text { DC-8-I }\end{array}$ & D WES-D8-80 & 15 Sep 80 & $\begin{array}{l}5 \text { of } \\
6 \text { of } \\
7 \text { of } \\
8 \text { of } \\
9 \text { of }\end{array}$ & $\begin{array}{l}9 \\
9 \\
9 \\
9 \\
9\end{array}$ & $\begin{array}{c}0.0-1.49 \\
1.49-6.45 \\
6.45-11.25 \\
11.25-16.25 \\
\\
16.25-21.15 \\
21.15-25.0 \\
25.0-29.15 \\
29.15-33.90 \\
33.90-38.65\end{array}$ & 2 & $\begin{array}{c}6 \& 4 \\
4 \\
4 \\
4\end{array}$ \\
\hline Det -6 & $\mathrm{CON}-5-\mathrm{A}$ & D WES-D9-80 & & 1 of & 1 & $0.0-2.85$ & 2 & 6 \\
\hline Det -6 & $\mathrm{CON}-6-\mathrm{A}$ & D WES-D 10-80 & & 1 of & 1 & $0.0-2.95$ & 3 & 6 \\
\hline Det-6 & $\begin{array}{l}\text { DC-9-A } \\
\text { DC-9-B } \\
\text { DC-9-C } \\
\text { DC-9-D } \\
\text { DC-9-E } \\
\text { DC-9-F } \\
\text { DC-9-G }\end{array}$ & D WES-E1-80 & & $\begin{array}{l}1 \text { of } \\
2 \text { of } \\
3 \text { of } \\
4 \text { of } \\
5 \text { of } \\
6 \text { of } \\
7 \text { of }\end{array}$ & $\begin{array}{l}7 \\
7 \\
7 \\
7 \\
7 \\
7 \\
7\end{array}$ & $\begin{array}{l}13.8-18.25 \\
18.25-22.65 \\
22.65-27.5 \\
27.5-31.8 \\
31.8-35.7 \\
35.7-40.0 \\
40.0-44.5\end{array}$ & $\begin{array}{l}8 \\
6 \\
7 \\
4 \\
4 \\
3 \\
3\end{array}$ & $\begin{array}{l}4 \\
4 \\
4 \\
4 \\
4 \\
4 \\
4\end{array}$ \\
\hline $\begin{array}{l}\text { Det }-6 \\
\text { Det }-6\end{array}$ & $\begin{array}{l}\mathrm{CON}-7 \\
\mathrm{DC}-10-\mathrm{A}\end{array}$ & D WES-E2-80 & & 1 of & 1 & $\begin{array}{ll}14.1 & -17.5 \\
17.5 & -18.1\end{array}$ & $\begin{array}{l}2 \\
3\end{array}$ & 4 \\
\hline Det-6 & $\begin{array}{l}\text { CON-8-A } \\
\text { CON-8-B } \\
\text { CON-8-C } \\
\text { CON-8-D } \\
\text { CON-8 } \\
\text { DC-11-E } \\
\text { DC-11-F } \\
\text { DC-11-G } \\
\text { DC-11-H } \\
\text { DC-11-I }\end{array}$ & D WES-L1-80 & & 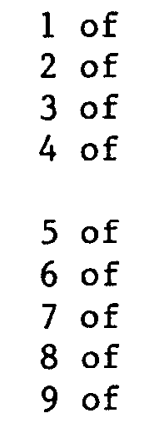 & $\begin{array}{l}9 \\
9 \\
9 \\
9 \\
9\end{array}$ & $\begin{array}{c}0.0-4.6 \\
4.6-8.6 \\
8.6-11.8 \\
11.8-16.3 \\
16.3-21.1 \\
21.1-25.8 \\
25.8-31.15 \\
31.15-35.5 \\
35.5-41.1\end{array}$ & $\begin{array}{l}2 \\
3 \\
2 \\
1 \\
\\
2 \\
5 \\
7 \\
3 \\
5\end{array}$ & $\begin{array}{c}6 \& 4 \\
4 \\
4 \\
4\end{array}$ \\
\hline Det-6 & CON-9-A & D WES-L2-80 & & 1 of & 1 & $0.0-3.15$ & 1 & 6 \\
\hline
\end{tabular}


Table 6

Concrete and Rock Core Test Results, DePere Lock and Dam

\begin{tabular}{|c|c|c|c|c|c|c|c|}
\hline $\begin{array}{c}\text { Drill Hole } \\
\text { No. } \\
\end{array}$ & $\begin{array}{c}\begin{array}{c}\text { Elevation } \\
\mathrm{ft}\end{array} \\
\end{array}$ & $\begin{array}{c}\text { Wet Unit } \\
\text { Weight } \\
\gamma_{\mathrm{m}}\left(1 \mathrm{~b} / \mathrm{ft}^{3}\right) \\
\end{array}$ & $\begin{array}{c}\text { Dry Unit } \\
\text { Weight } \\
\gamma_{\mathrm{d}}\left(1 \mathrm{~b} / \mathrm{ft}^{3}\right) \\
\end{array}$ & 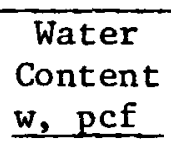 & $\begin{array}{c}\text { Compressive } \\
\text { Strength } \\
\text { qu, psi }\end{array}$ & 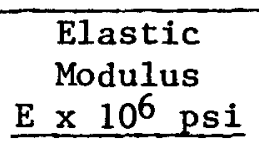 & $\begin{array}{c}\text { Poisson's } \\
\text { Ratio } \\
\end{array}$ \\
\hline \multicolumn{8}{|l|}{ Concrete } \\
\hline $\begin{array}{l}D-1-80 \\
D-1-80 \\
D-1-80\end{array}$ & $\begin{array}{l}593.47 \\
584.47 \\
575.57\end{array}$ & $\begin{array}{l}152.4 \\
153.8 \\
151.9 \\
\end{array}$ & $\begin{array}{l}145.4 \\
146.4 \\
145.2 \\
\end{array}$ & $\begin{array}{l}4.8 \\
4.5 \\
4.6 \\
\end{array}$ & $\begin{array}{l}8,810 \\
7,160 \\
9,640 \\
\end{array}$ & $\begin{array}{l}7.25 \\
7.39 \\
6.12 \\
\end{array}$ & $\begin{array}{l}0.26 \\
0.23 \\
0.11 \\
\end{array}$ \\
\hline \multicolumn{2}{|c|}{$\begin{array}{r}\text { Avg } \\
S\end{array}$} & $\begin{array}{r}152.7 \\
0.98\end{array}$ & $\begin{array}{r}145.7 \\
0.64\end{array}$ & $\begin{array}{l}4.6 \\
0.15\end{array}$ & $\begin{array}{l}8,540 \\
1,260\end{array}$ & $\begin{array}{l}6.92 \\
0.70\end{array}$ & $\begin{array}{l}0.20 \\
0.08\end{array}$ \\
\hline \multicolumn{8}{|l|}{ Rock } \\
\hline $\begin{array}{l}D-1-80 \\
D-1-80 \\
D-7-80 \\
D-7-80 \\
D-8-80 \\
D-8-80\end{array}$ & $\begin{array}{l}568.77 \\
566.77 \\
574.97 \\
572.47 \\
571.40 \\
569.60 \\
\end{array}$ & $\begin{array}{l}171.2 \\
173.6 \\
164.9 \\
169.8 \\
170.6 \\
171.6 \\
\end{array}$ & $\begin{array}{l}169.5 \\
172.2 \\
163.4 \\
168.1 \\
169.9 \\
171.4 \\
\end{array}$ & $\begin{array}{l}1.0 \\
0.8 \\
0.9 \\
1.0 \\
0.4 \\
0.1 \\
\end{array}$ & $\begin{array}{l}14,260 \\
15,260 \\
16,150 \\
19,520 \\
30,640 \\
30,560 \\
\end{array}$ & $\begin{array}{r}8.00 \\
8.00 \\
5.31 \\
10.00 \\
8.00 \\
10.00 \\
\end{array}$ & $\begin{array}{l}0.14 \\
0.21 \\
0.22 \\
0.24 \\
0.24 \\
0.30 \\
\end{array}$ \\
\hline \multicolumn{2}{|c|}{$\begin{array}{r}\text { Avg } \\
S\end{array}$} & $\begin{array}{r}170.3 \\
2.93\end{array}$ & $\begin{array}{r}169.1 \\
3.14\end{array}$ & $\begin{array}{l}0.7 \\
0.37\end{array}$ & $\begin{array}{r}21,070 \\
7,590\end{array}$ & $\begin{array}{l}8.22 \\
1.73\end{array}$ & $\begin{array}{l}0.23 \\
0.05\end{array}$ \\
\hline
\end{tabular}

Avg, average

$s$, standard deviation 


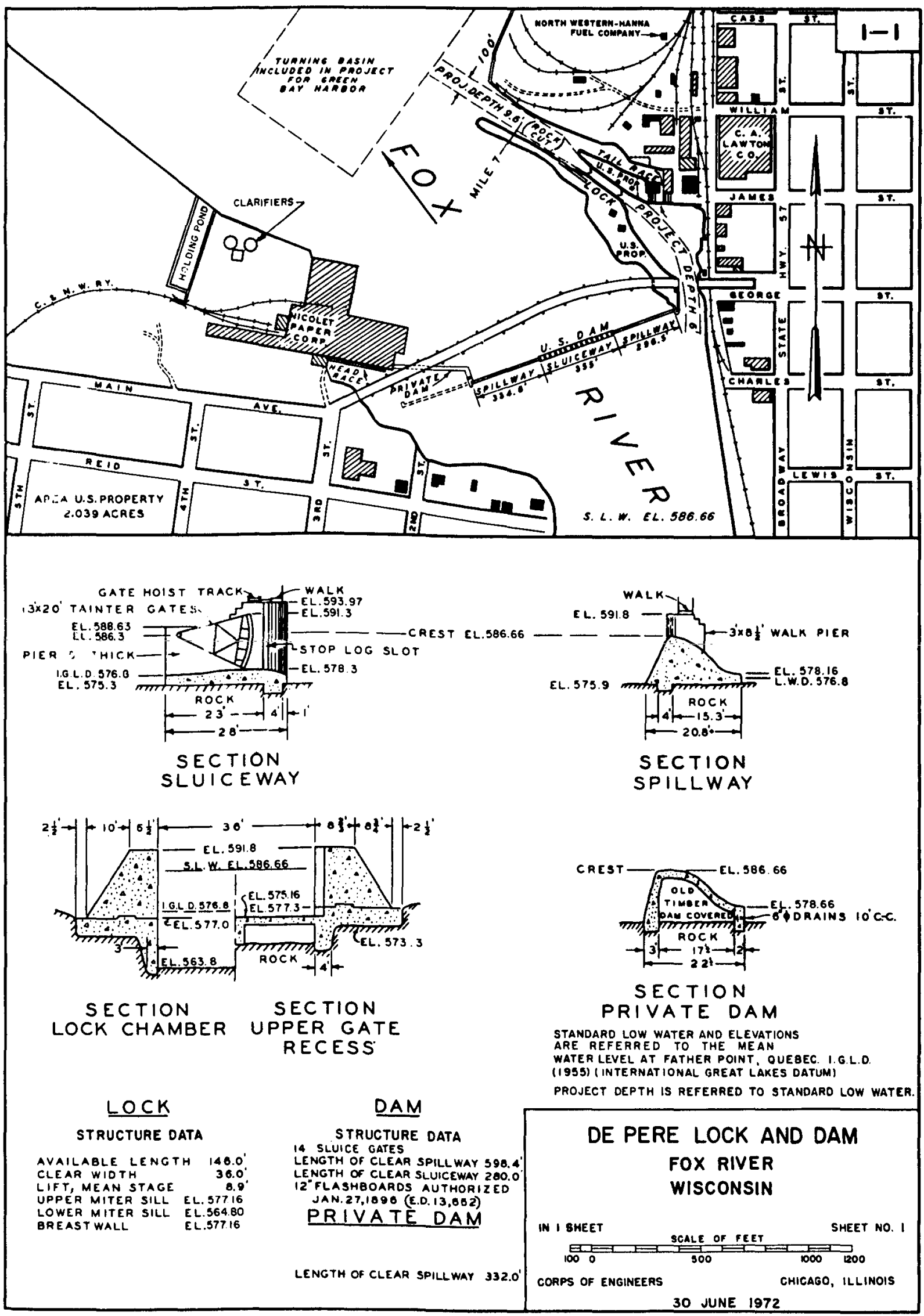




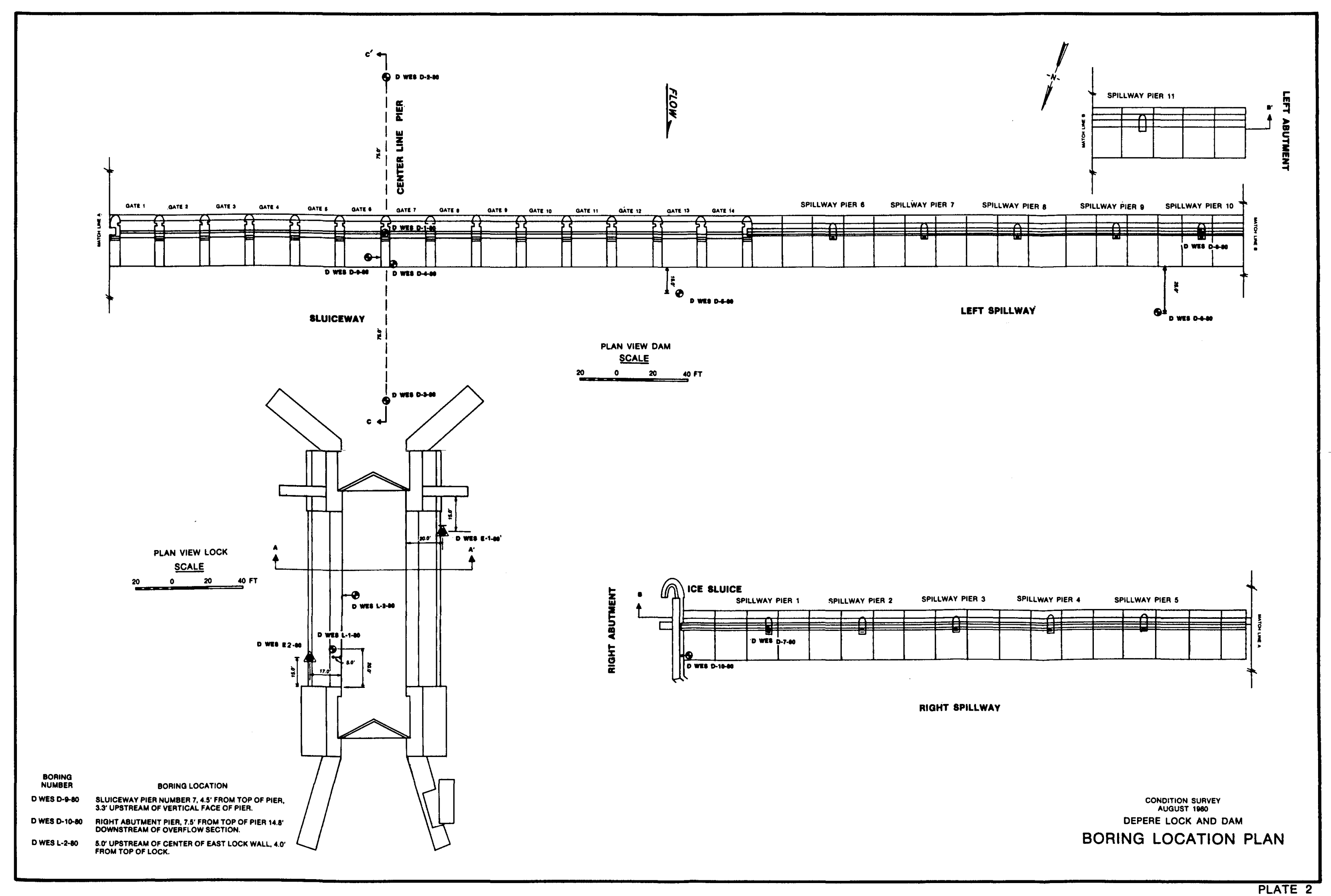




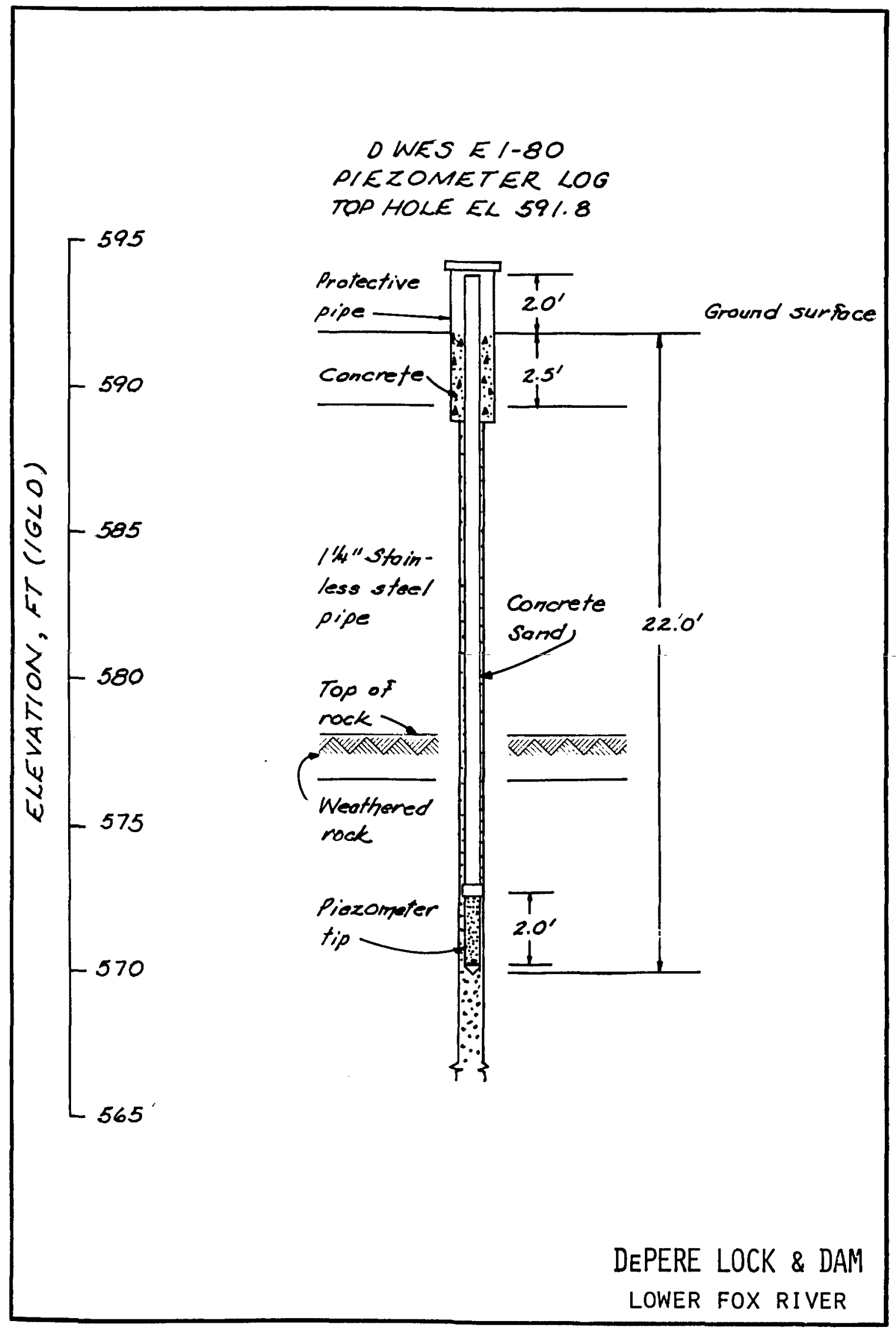




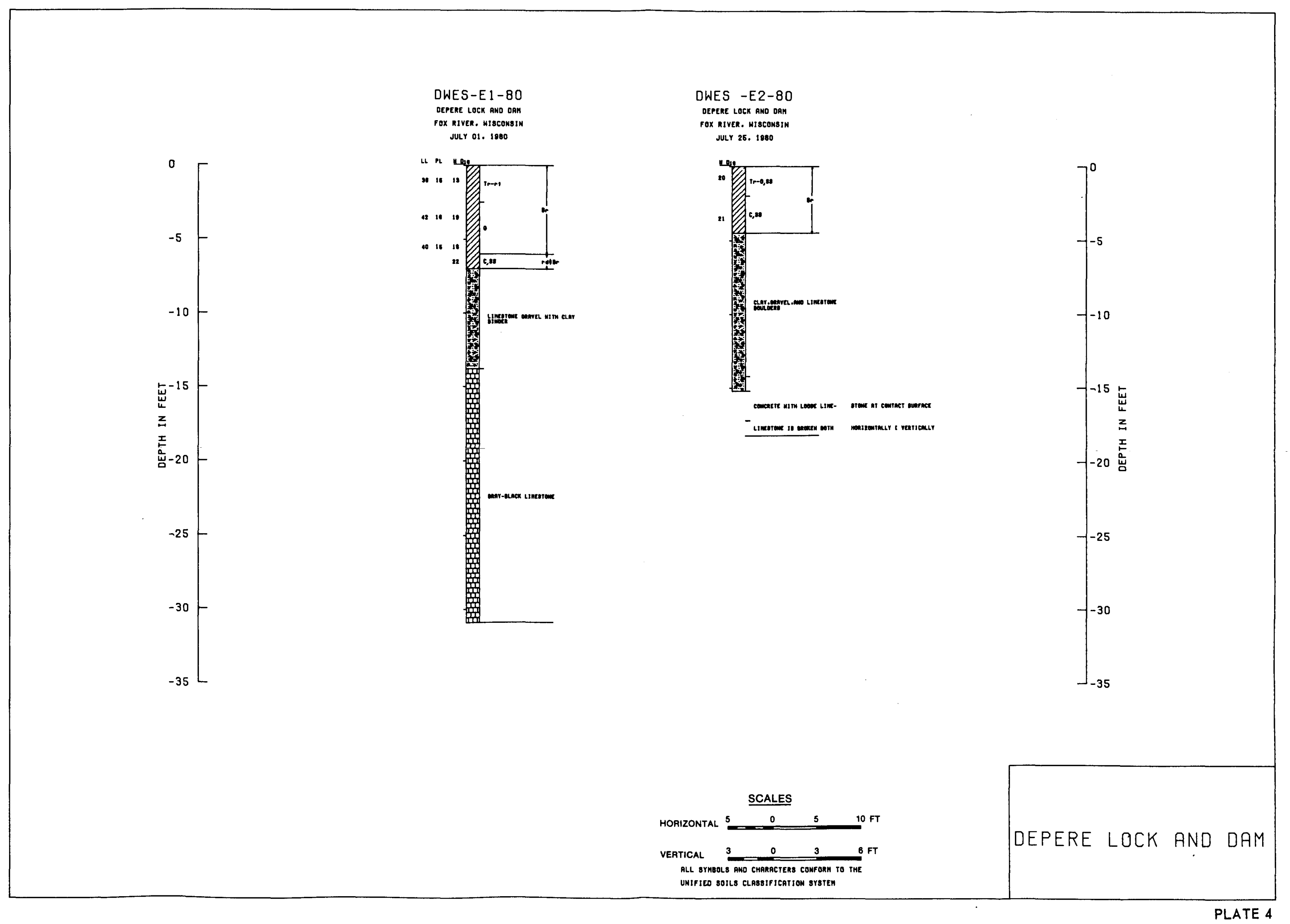



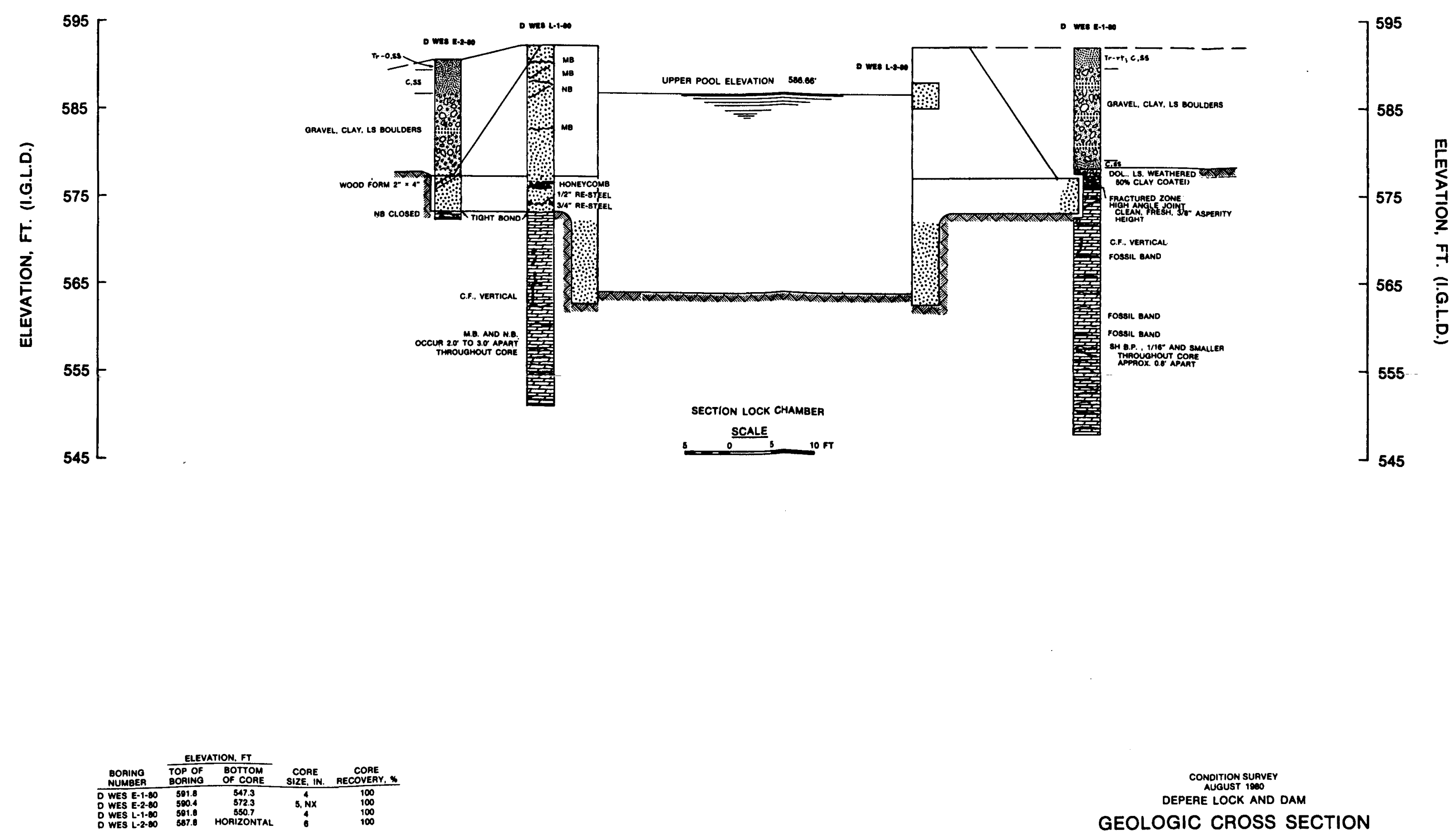


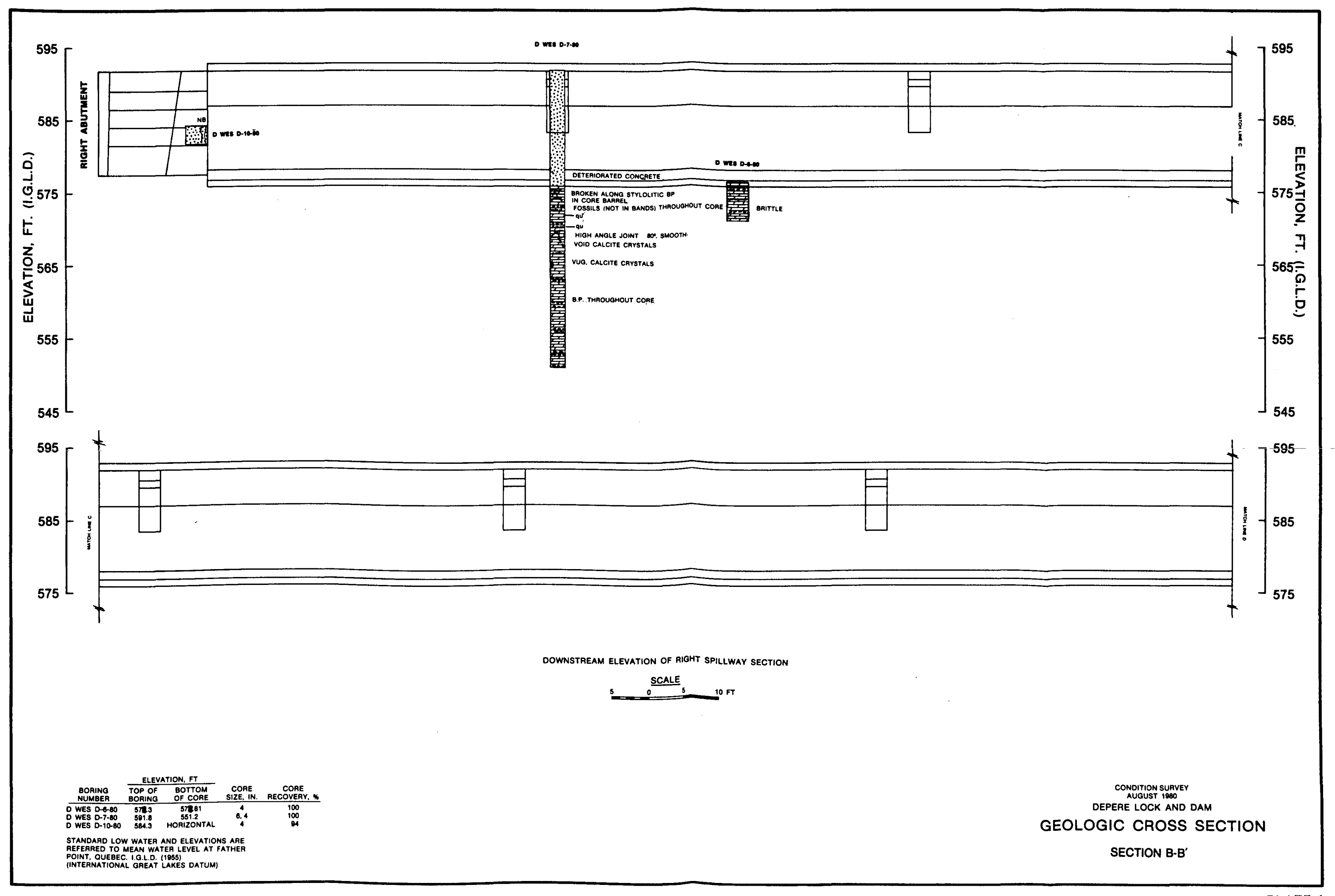

PLATE 6 


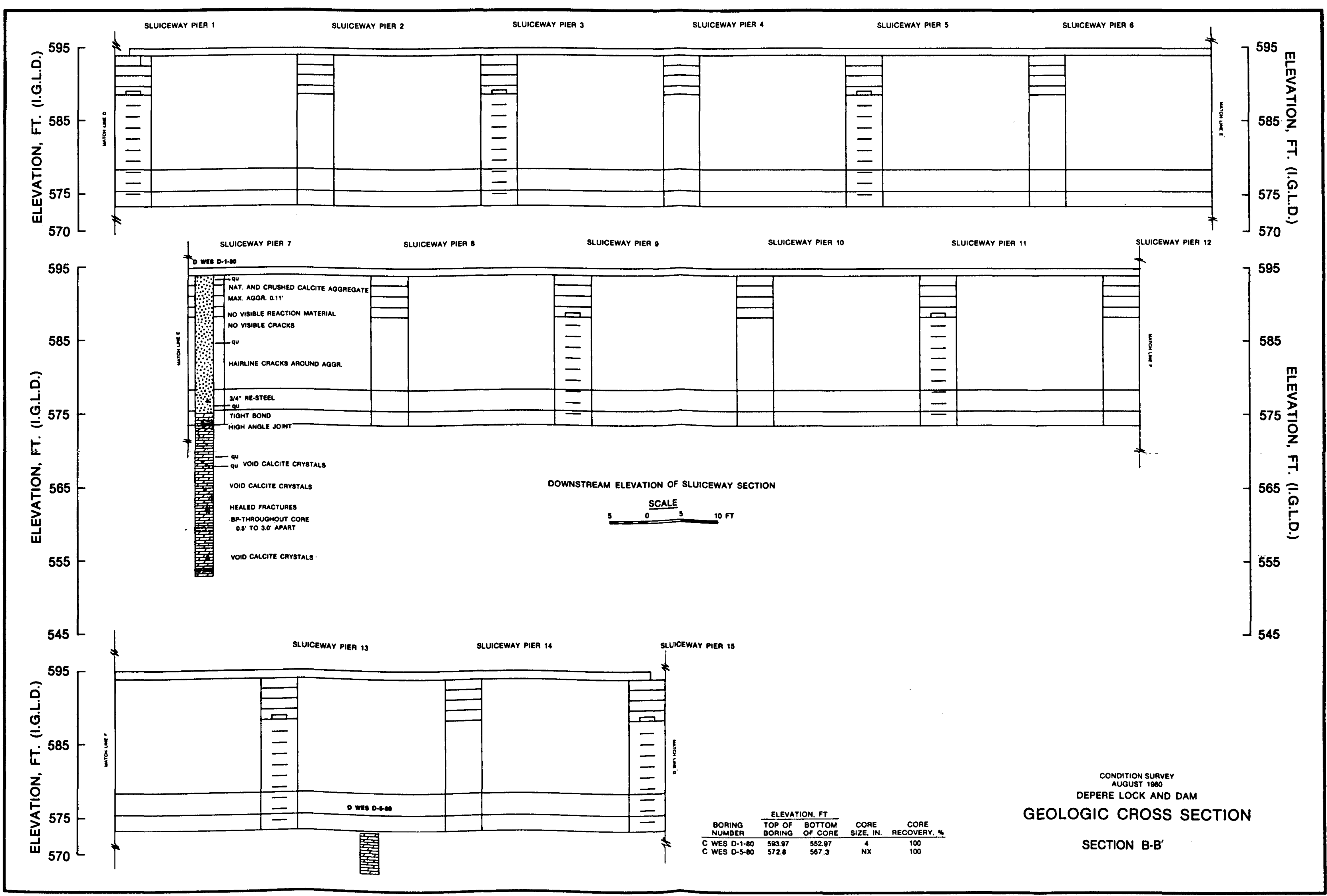




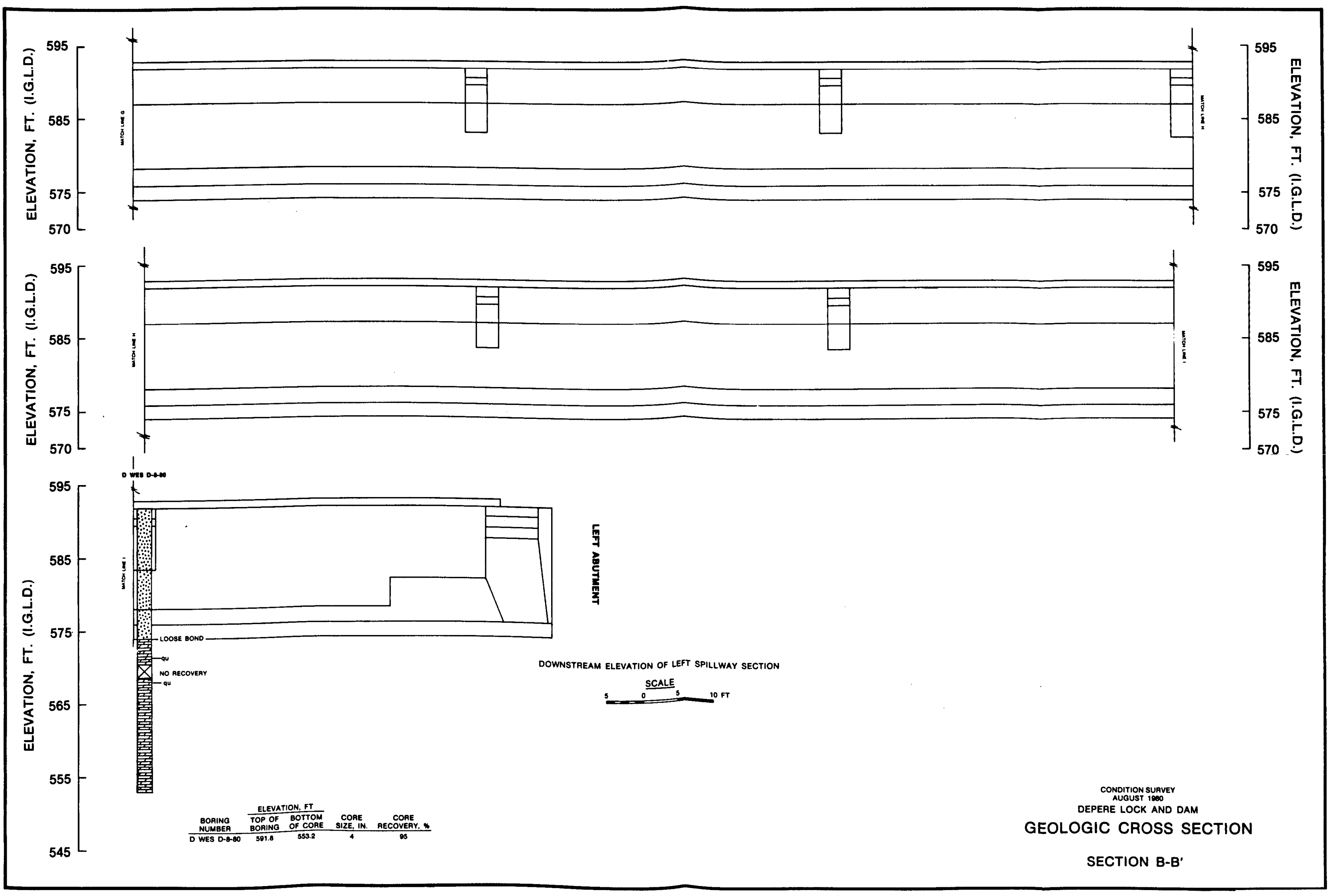




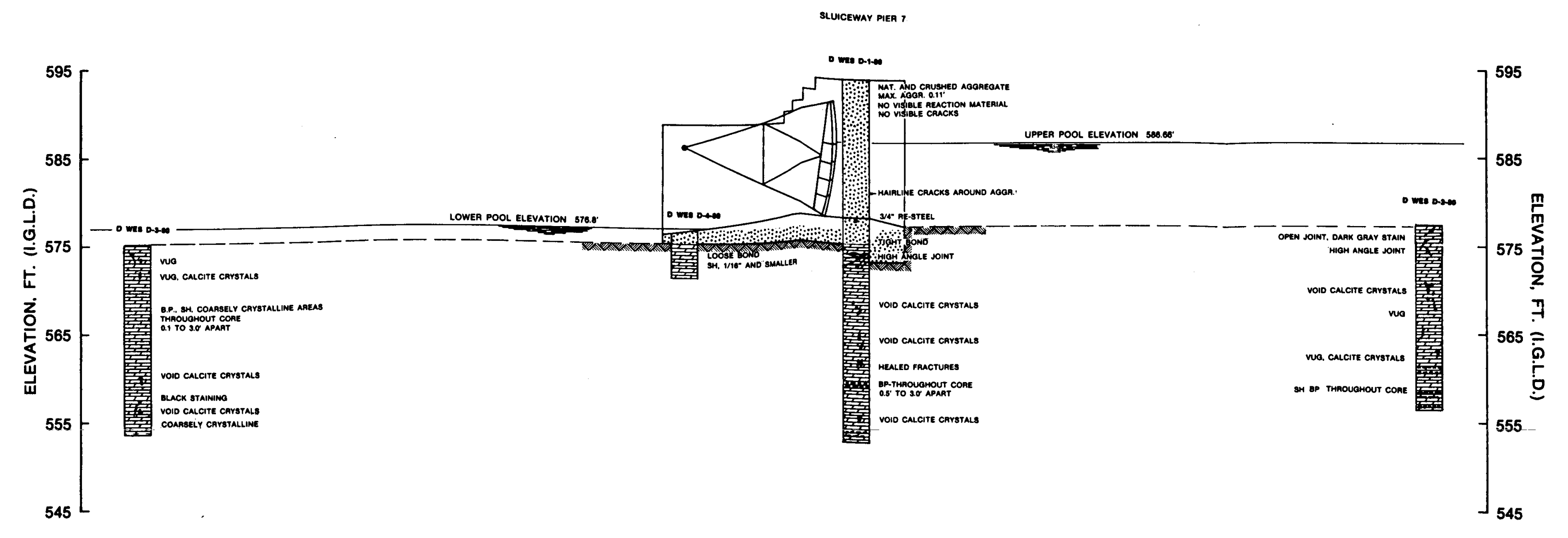

SECTION OF TAINTER GATE PIER

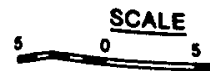

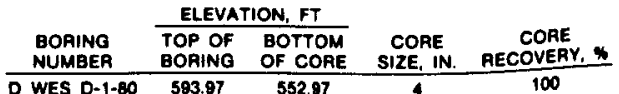

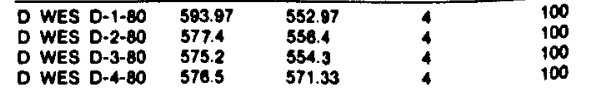

SECTION C.C 


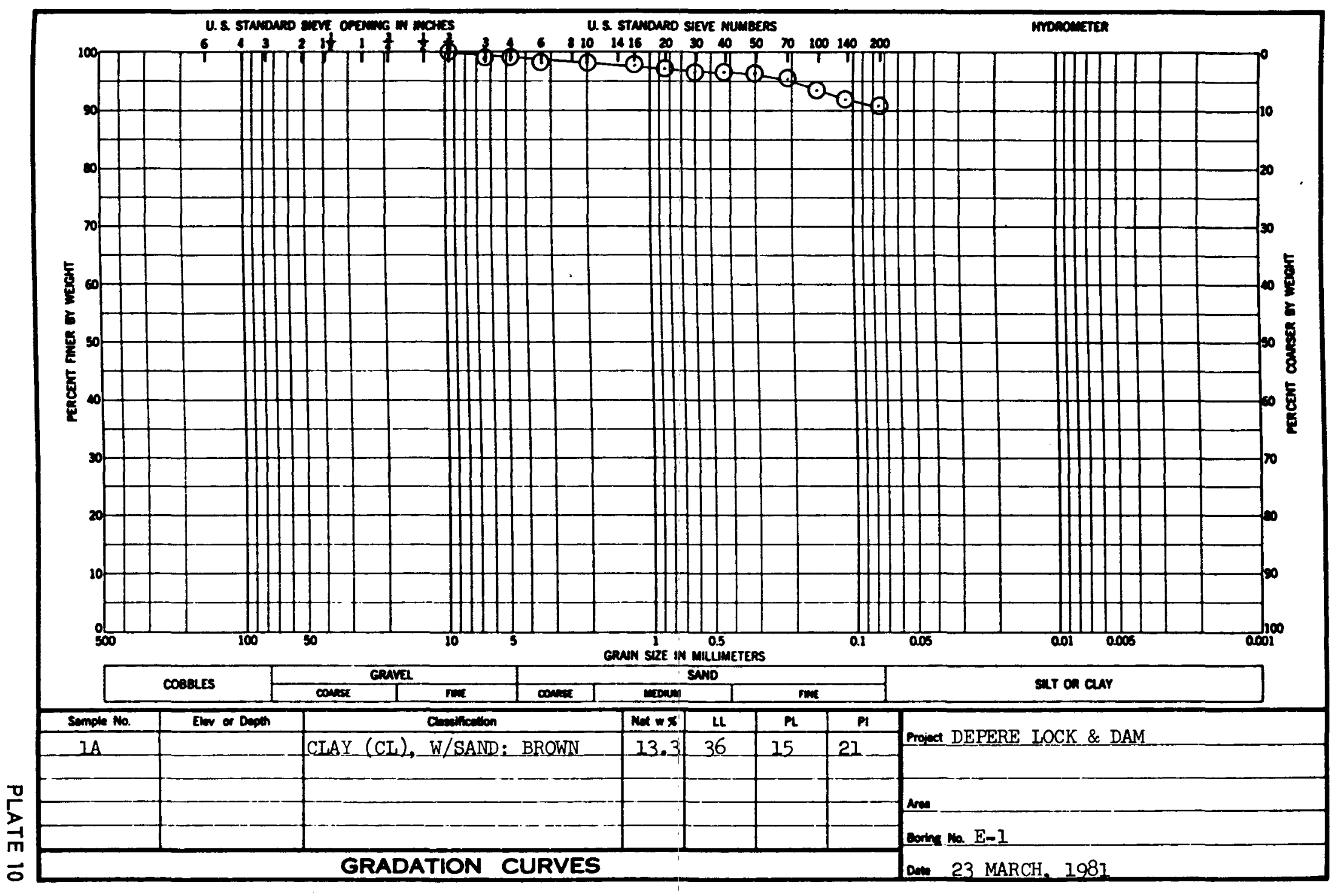

ENG, mank 2087 


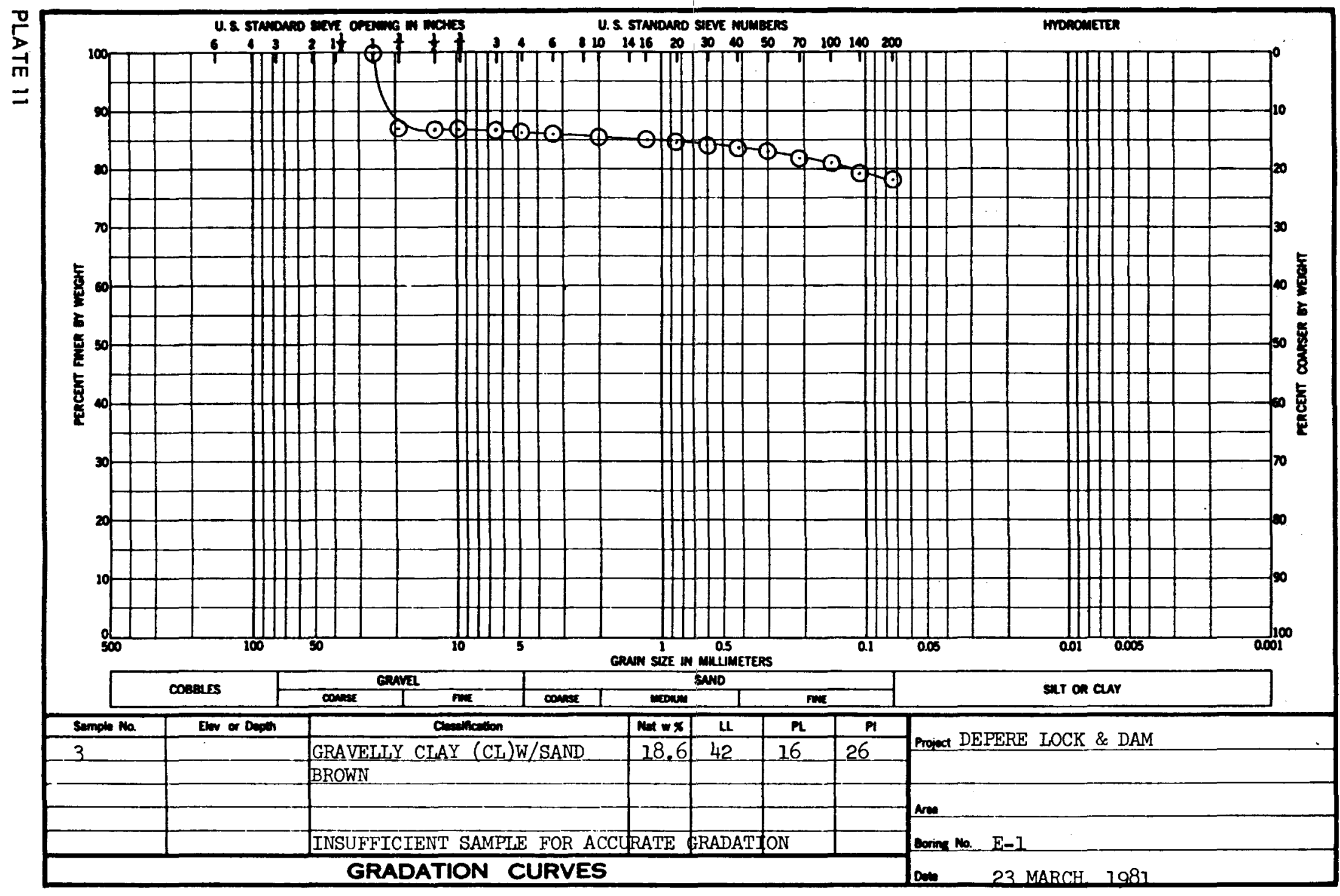

ENG , ronar 2087 


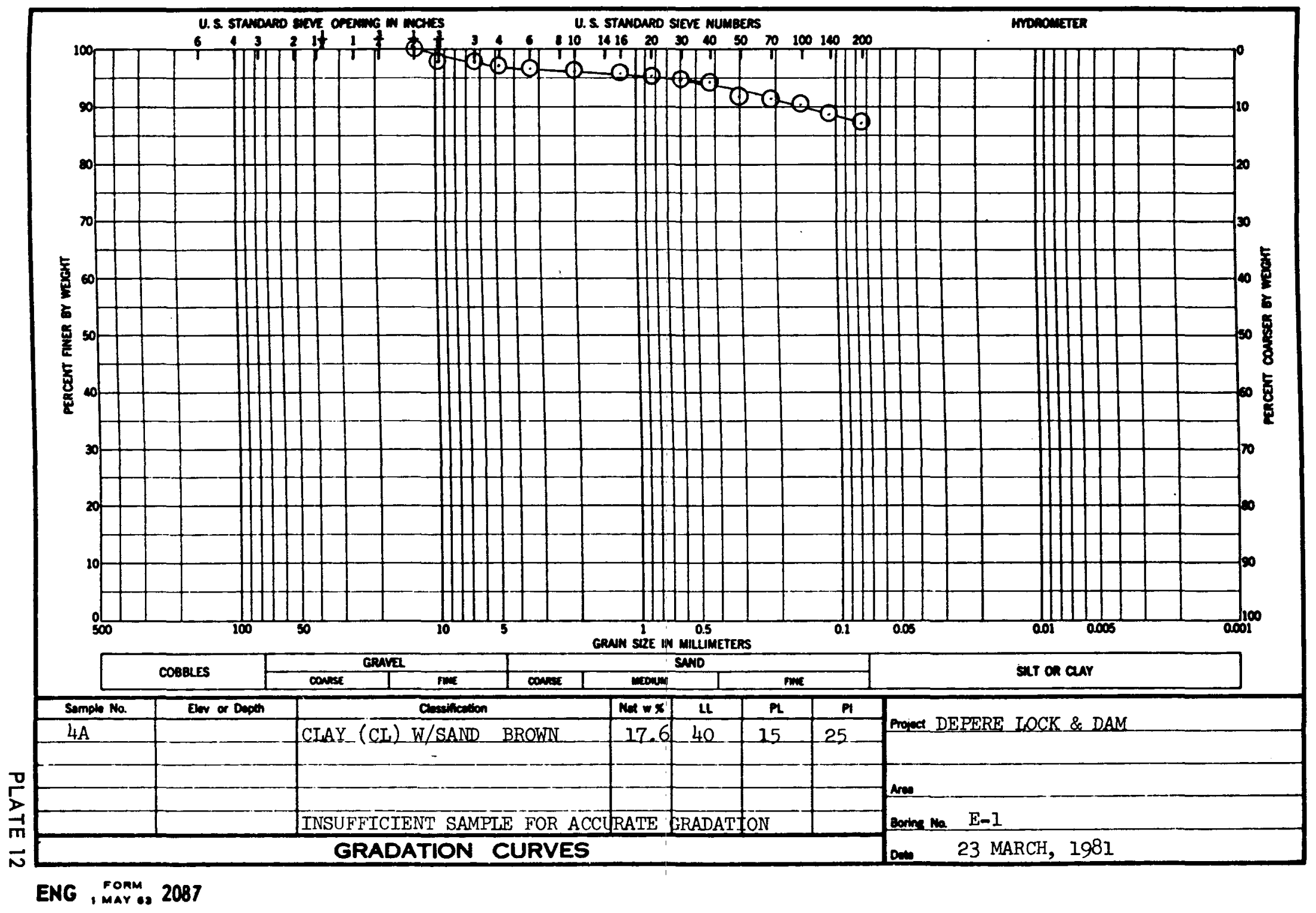




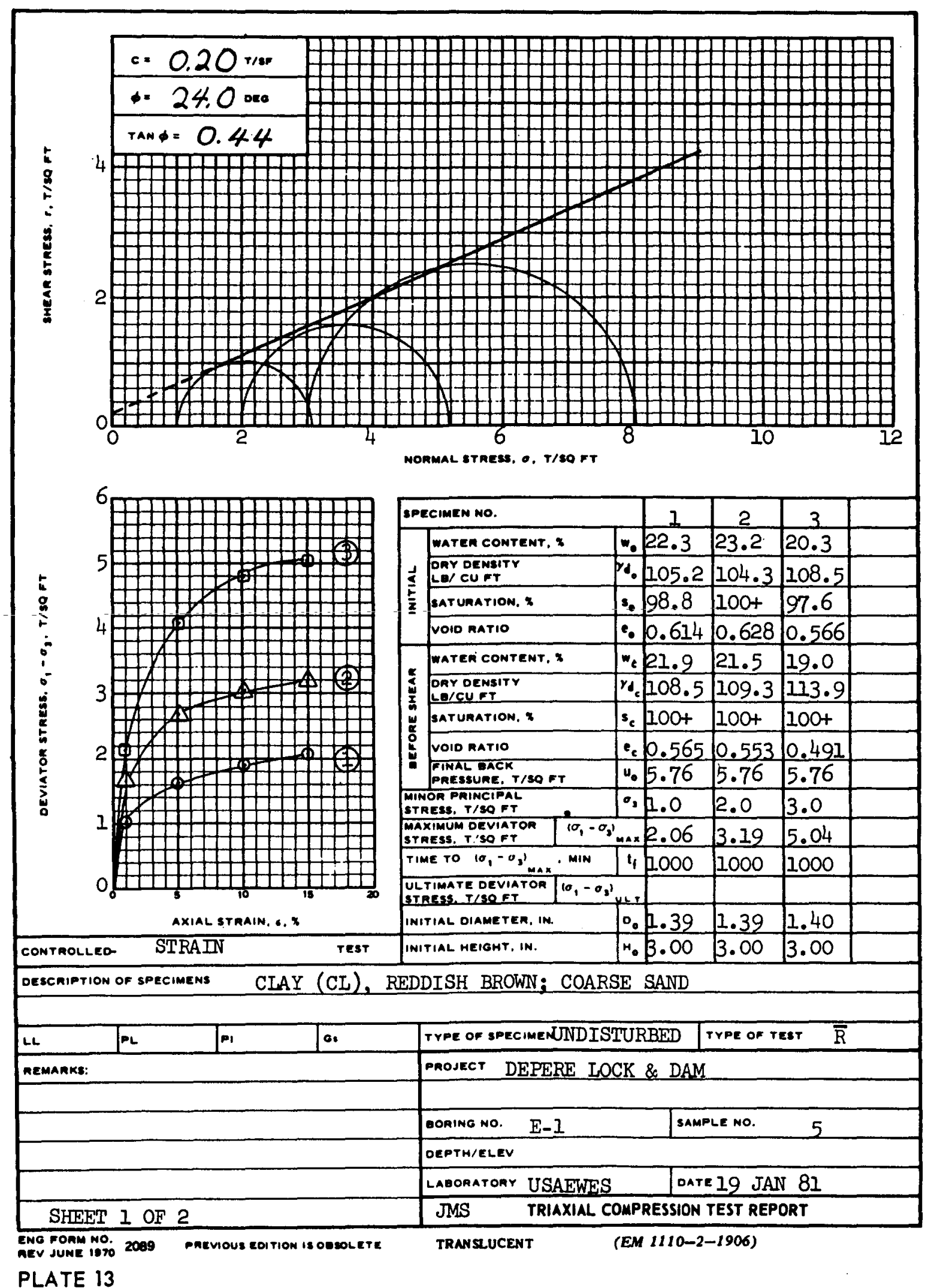




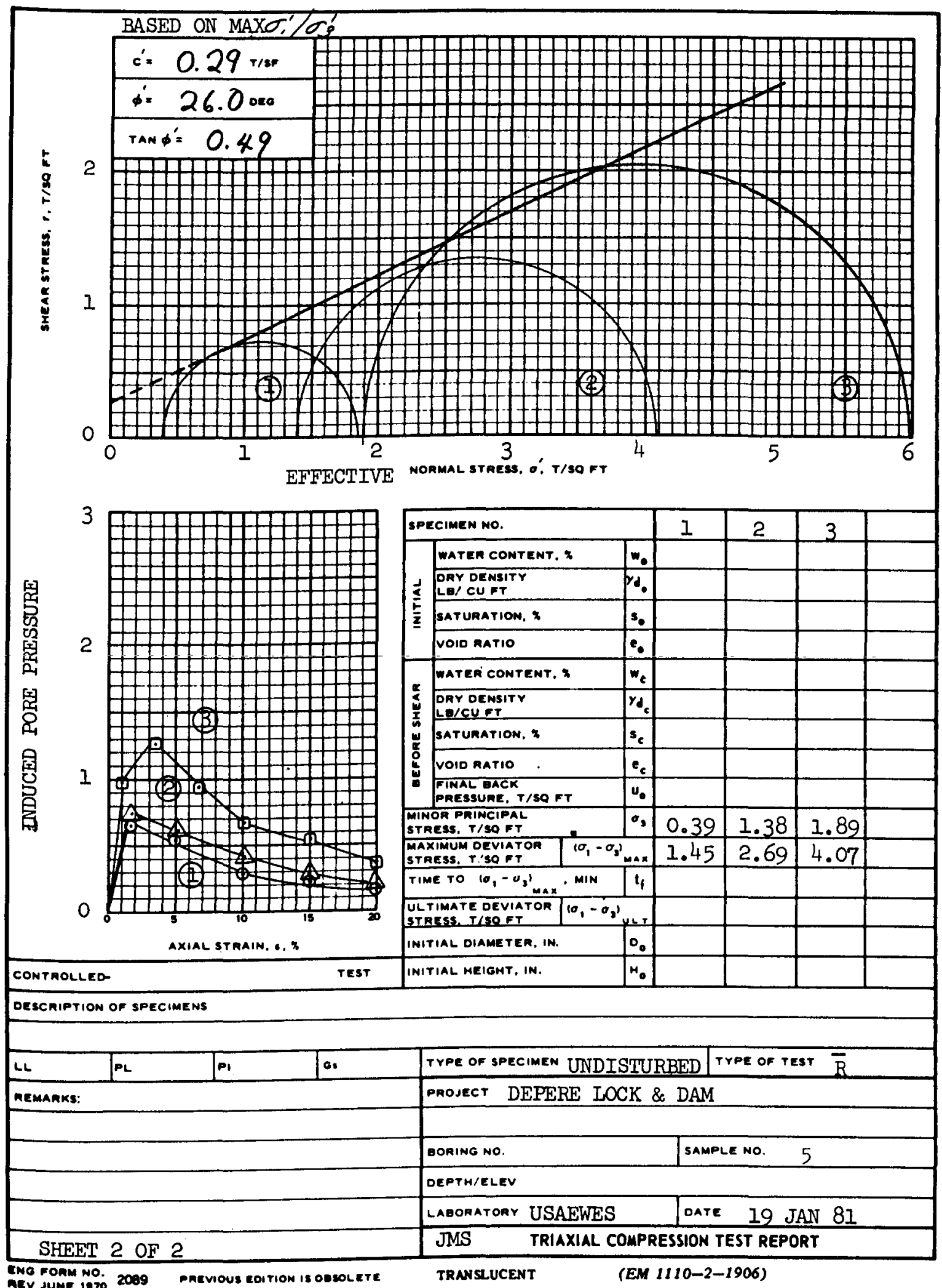

PLATE 14 


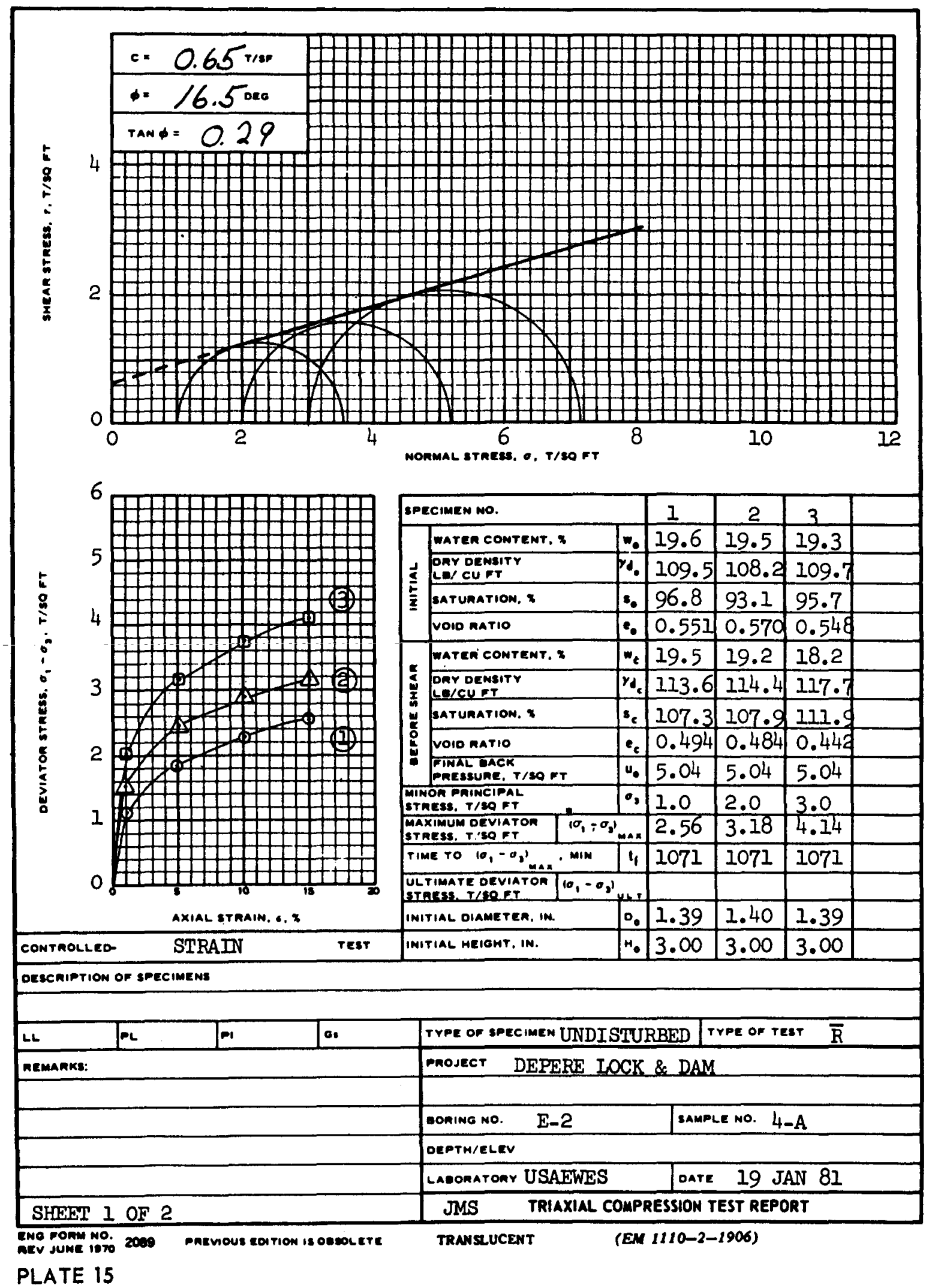



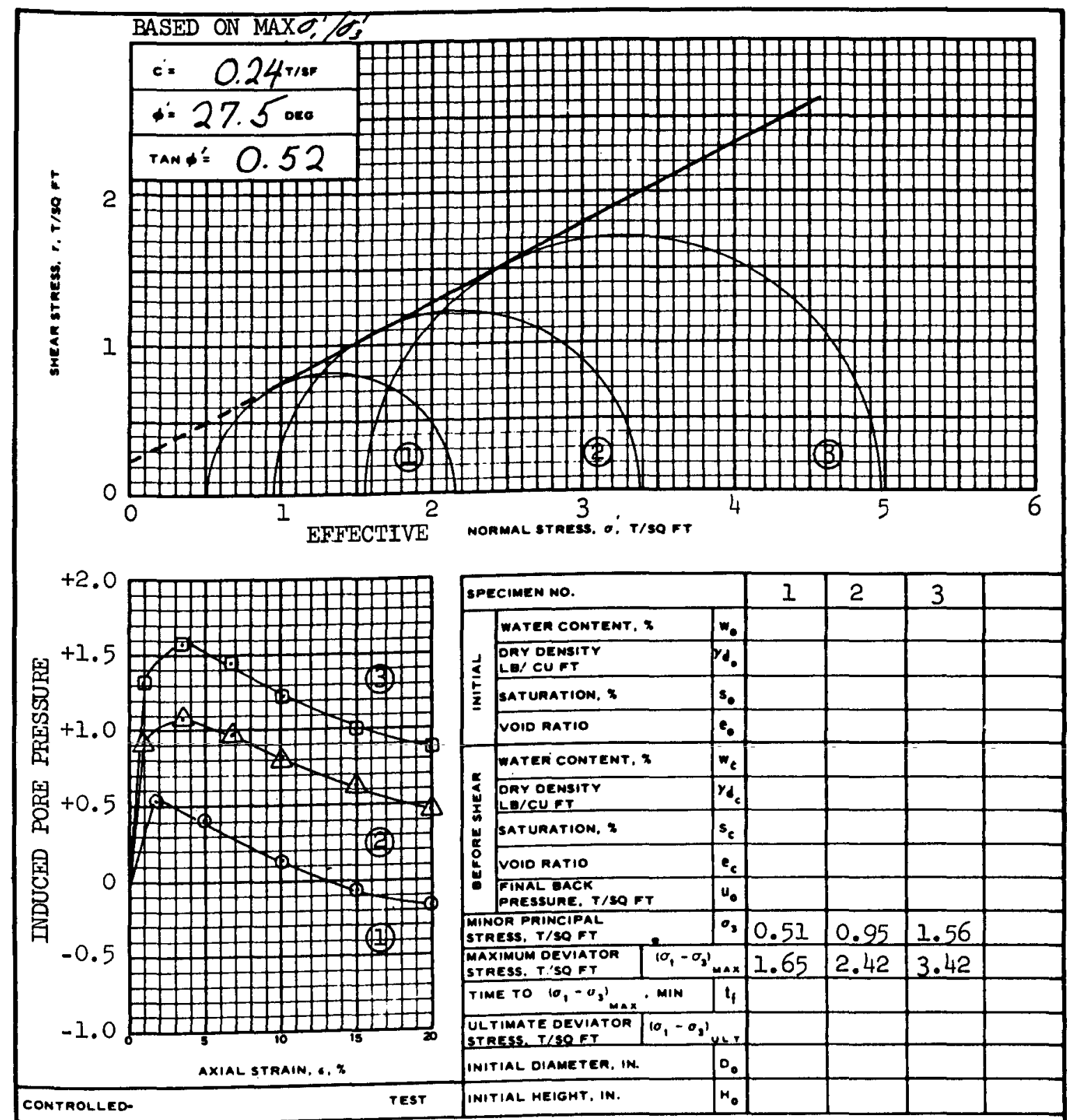

\begin{tabular}{|c|c|c|c|}
\hline CONTROLLEO & TEST & INITIAL HEIGHT, IN. & $\mathrm{mo}_{0}$ \\
\hline DESCRIPTION OF SPECIMENS & CLAY (CL), & ROWN; COARSE & \\
\hline
\end{tabular}

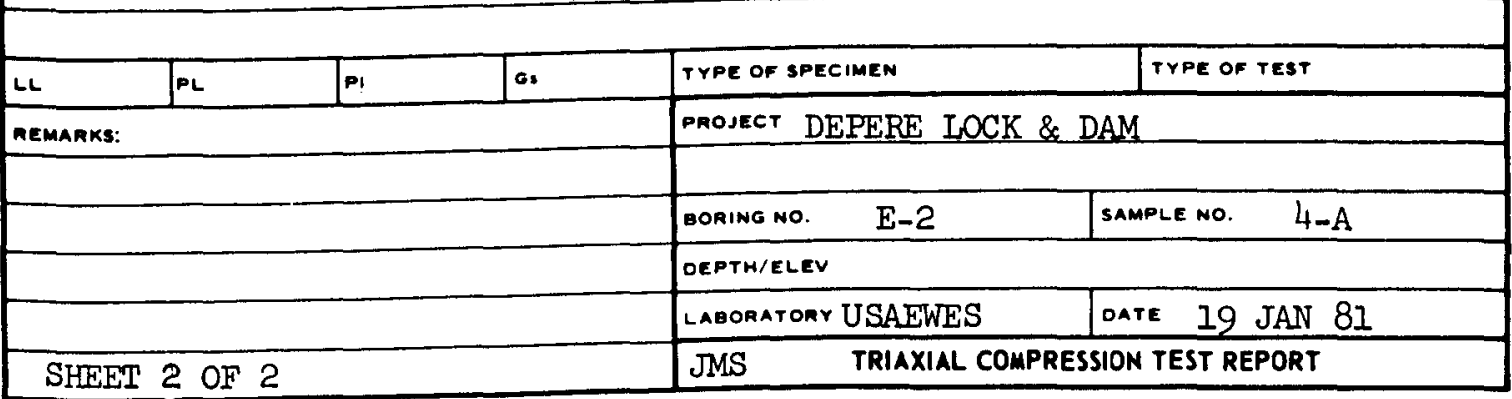




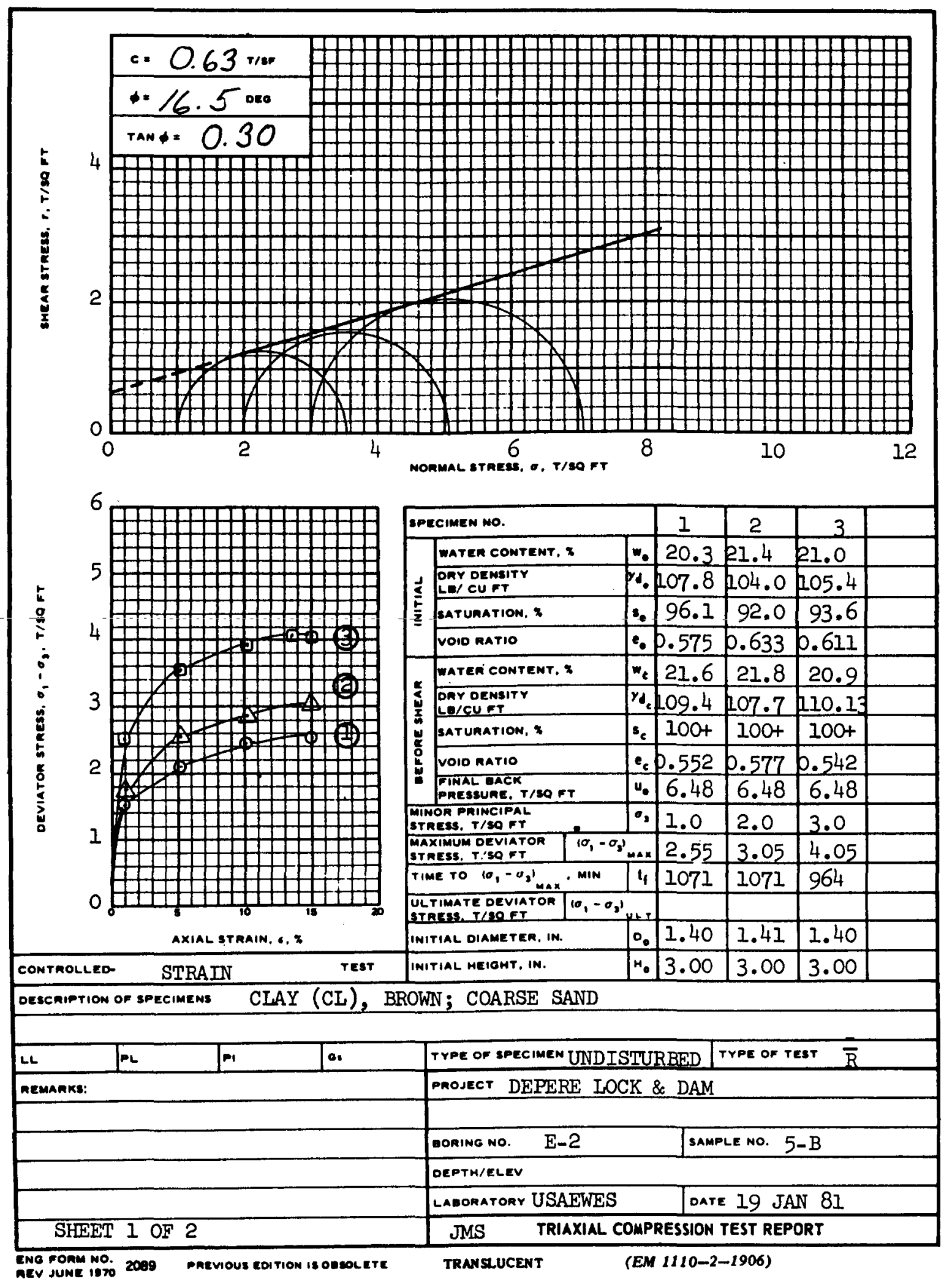

PLATE 17 


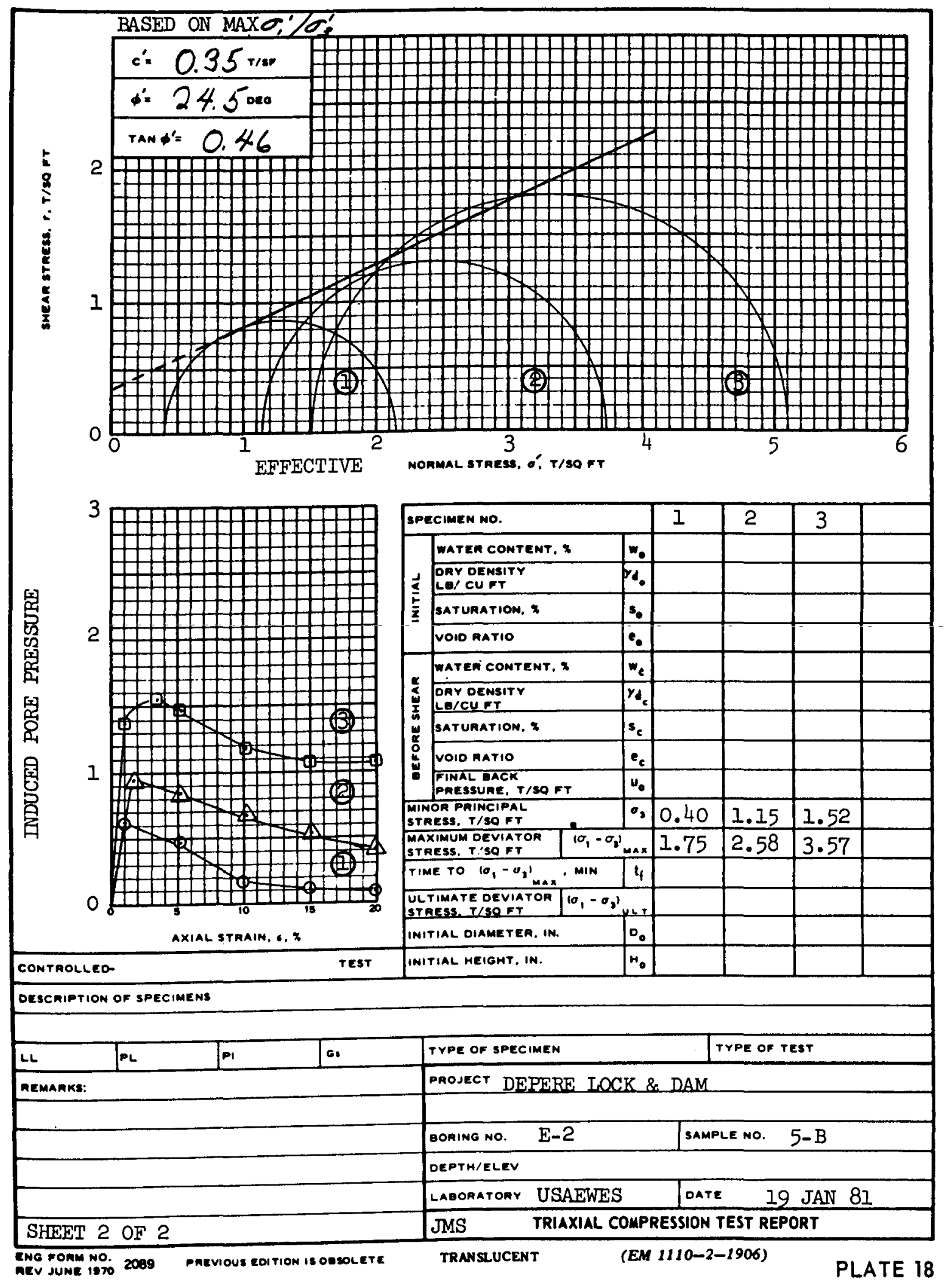




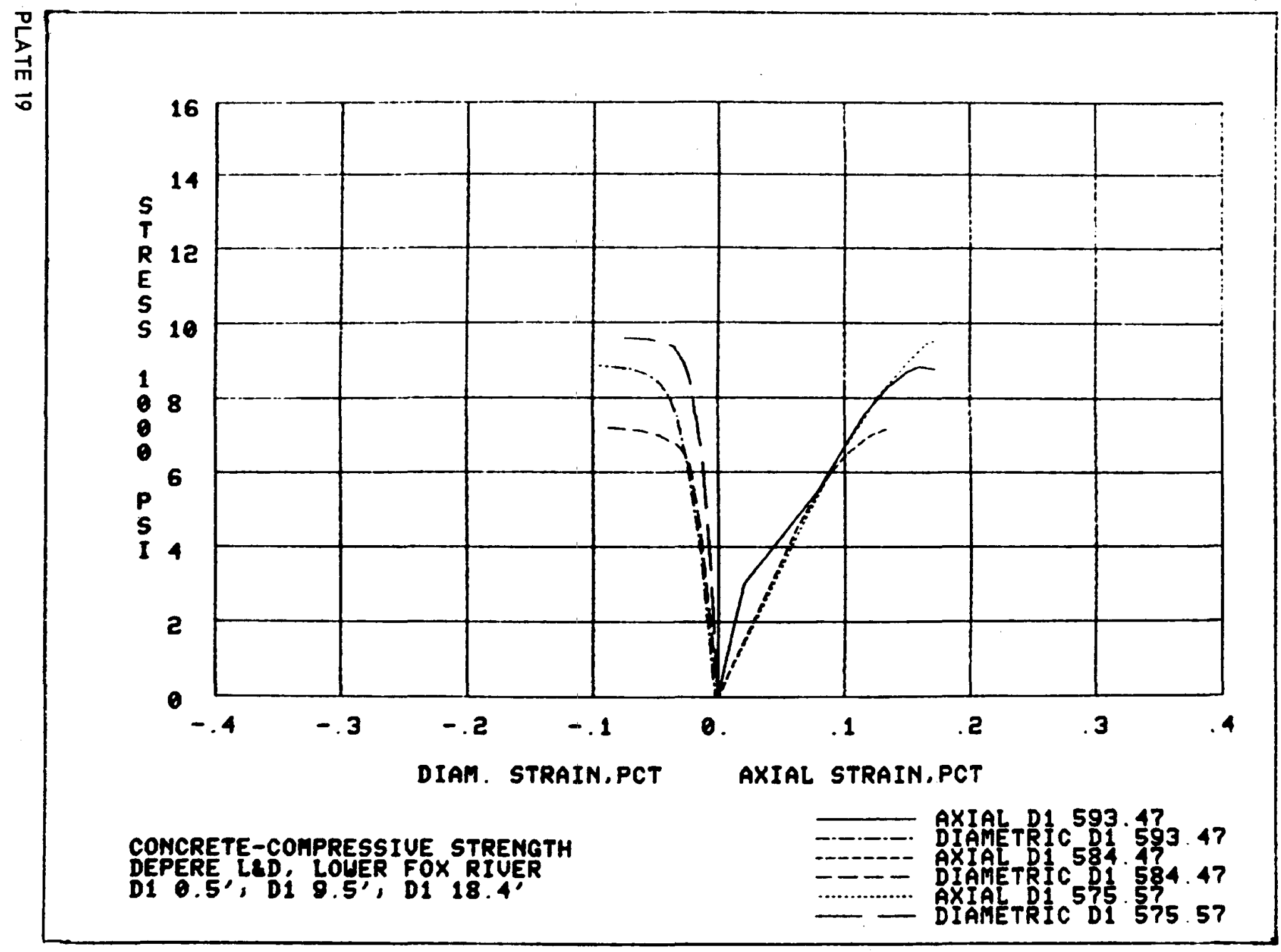




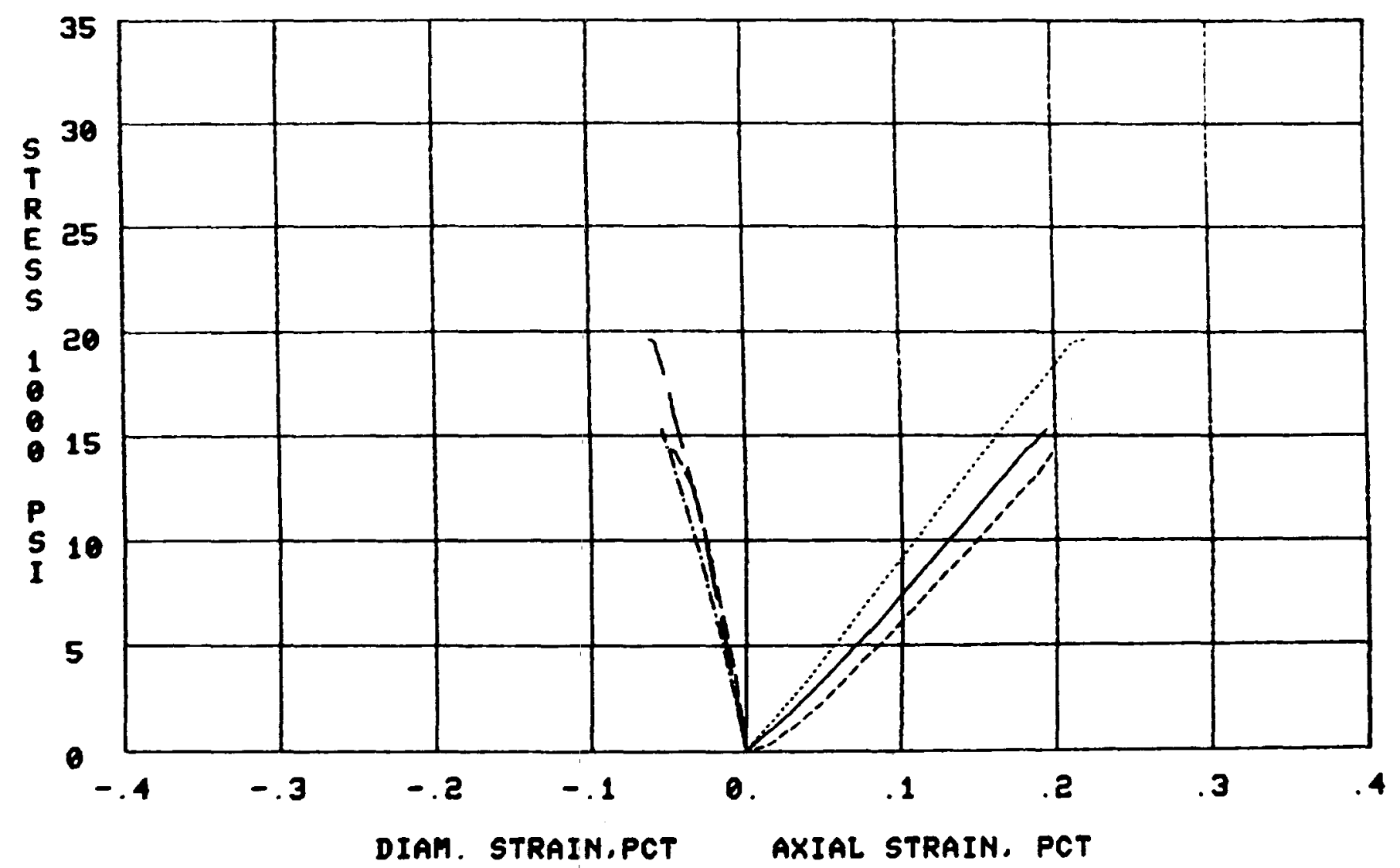

- AXIALCD1 566.736 .77 ROCK-COMPRESSIUE STRENGTH
5
$\frac{5}{4}$
DEPERE LRD LOUER, FOX FIUER
D1 $27.2 \%, D_{1} 25.2,$, D7 19.33 , ROCK-COMPRESSIUE STRENGTH
5
$\frac{1}{1}$
DEPERE LED LOUER, FOX FIUER
D1 $27.2^{\prime}, D_{1} 25.2,$, D7 19.33 , -..-- AXIAL D1 568. 35.77 - - DIANETRE C DI 568.77 ……- DIAMETRIC D 572.47 


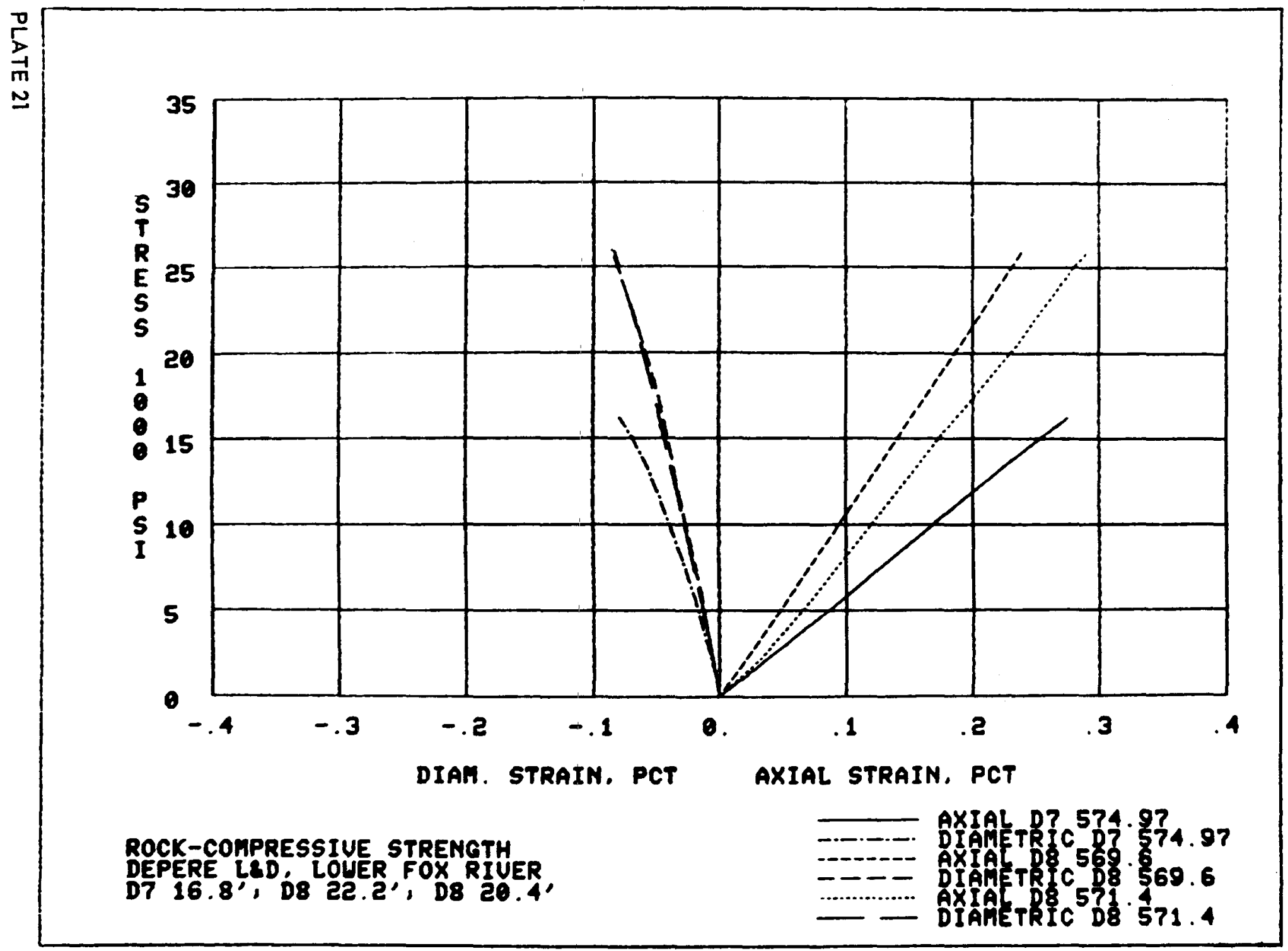




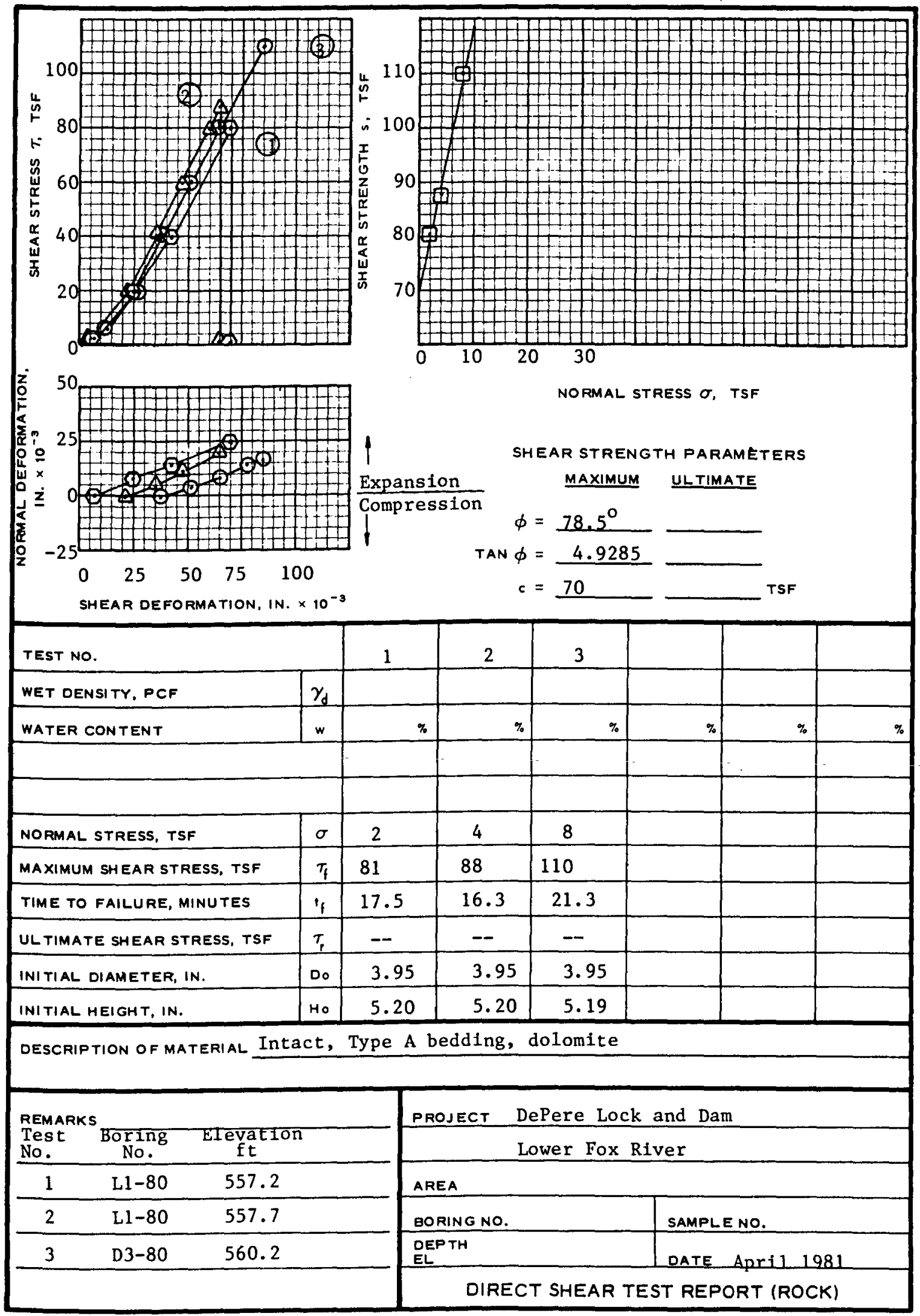

WES FORM 1490 EDITION OF JUN 65 IS OBSOLETE

PLATE 22 

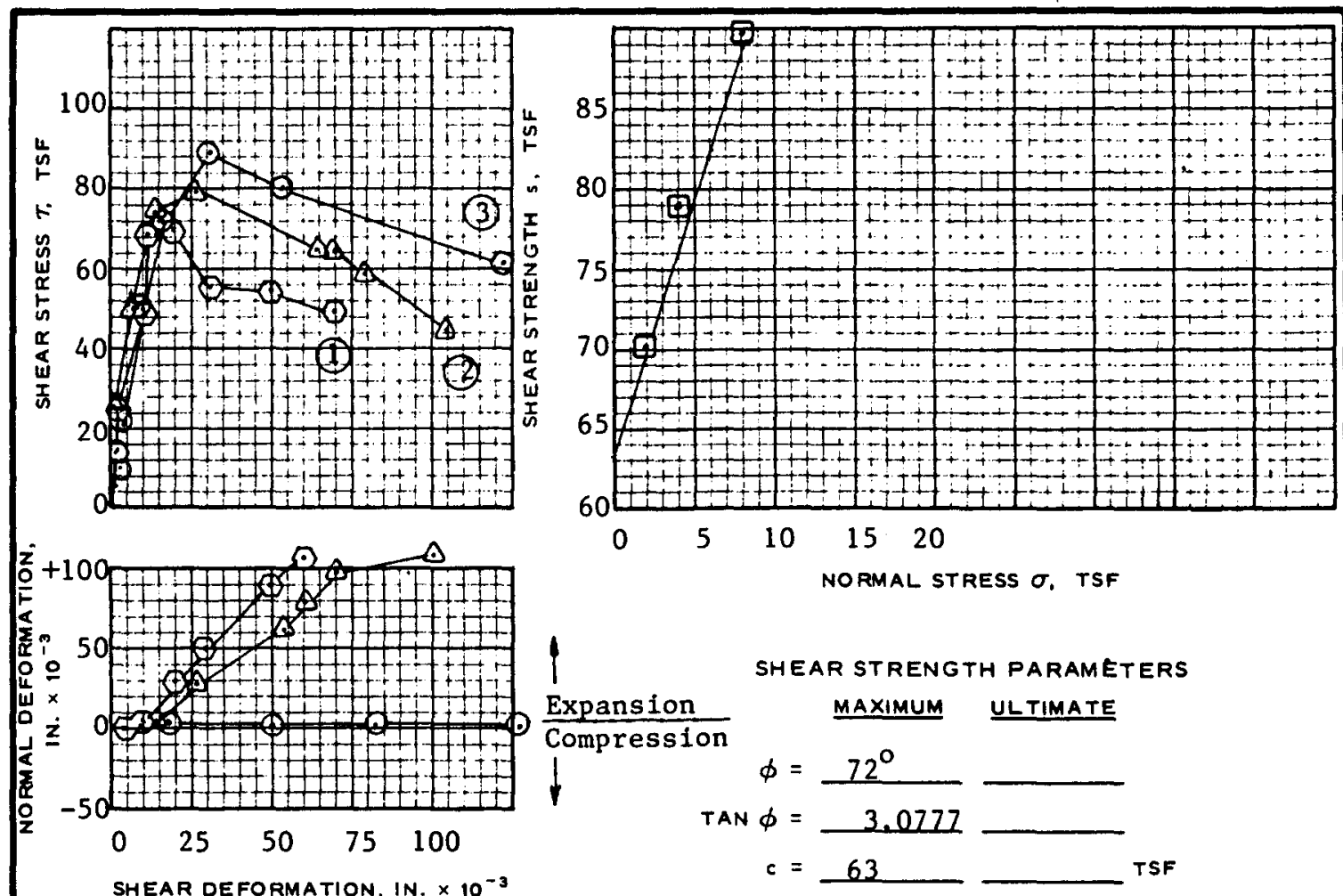

\section{ETERS}

Expansion

$$
\begin{aligned}
\phi & =\frac{72^{\circ}}{3.0777} \\
\phi & =63
\end{aligned}
$$

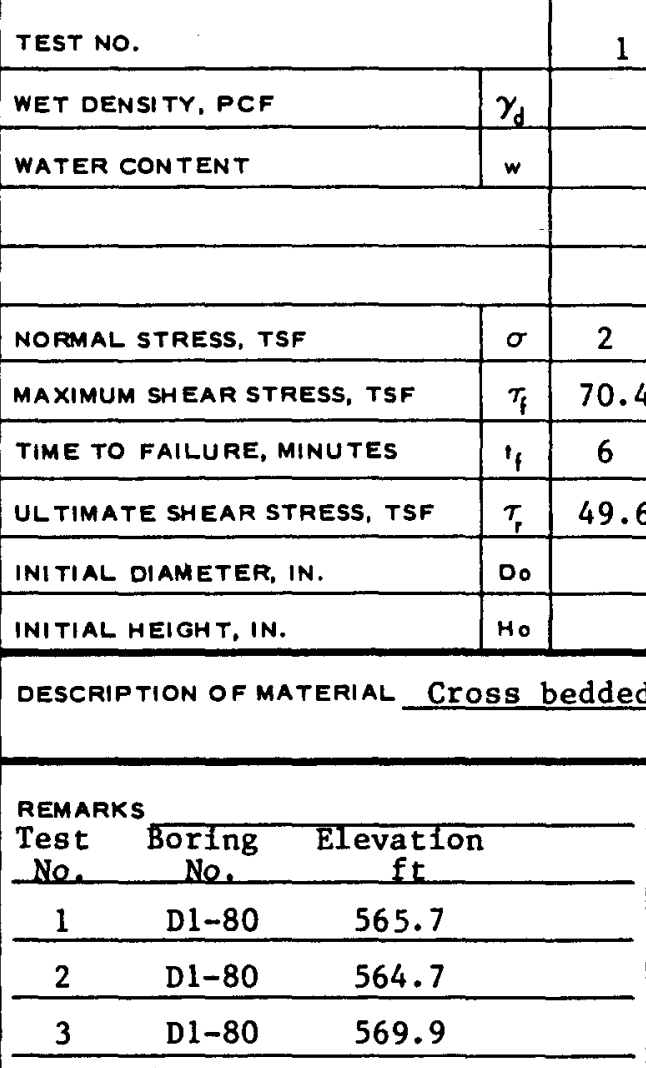

PROJECT DePere Lock and Dam

\begin{tabular}{|c|c|}
\hline BORING NO. & SAMPLE NO. \\
\hline $\begin{array}{l}\text { DEP TH } \\
\text { EL }\end{array}$ & OATE April 1981 \\
\hline
\end{tabular}
Lower Fox River 

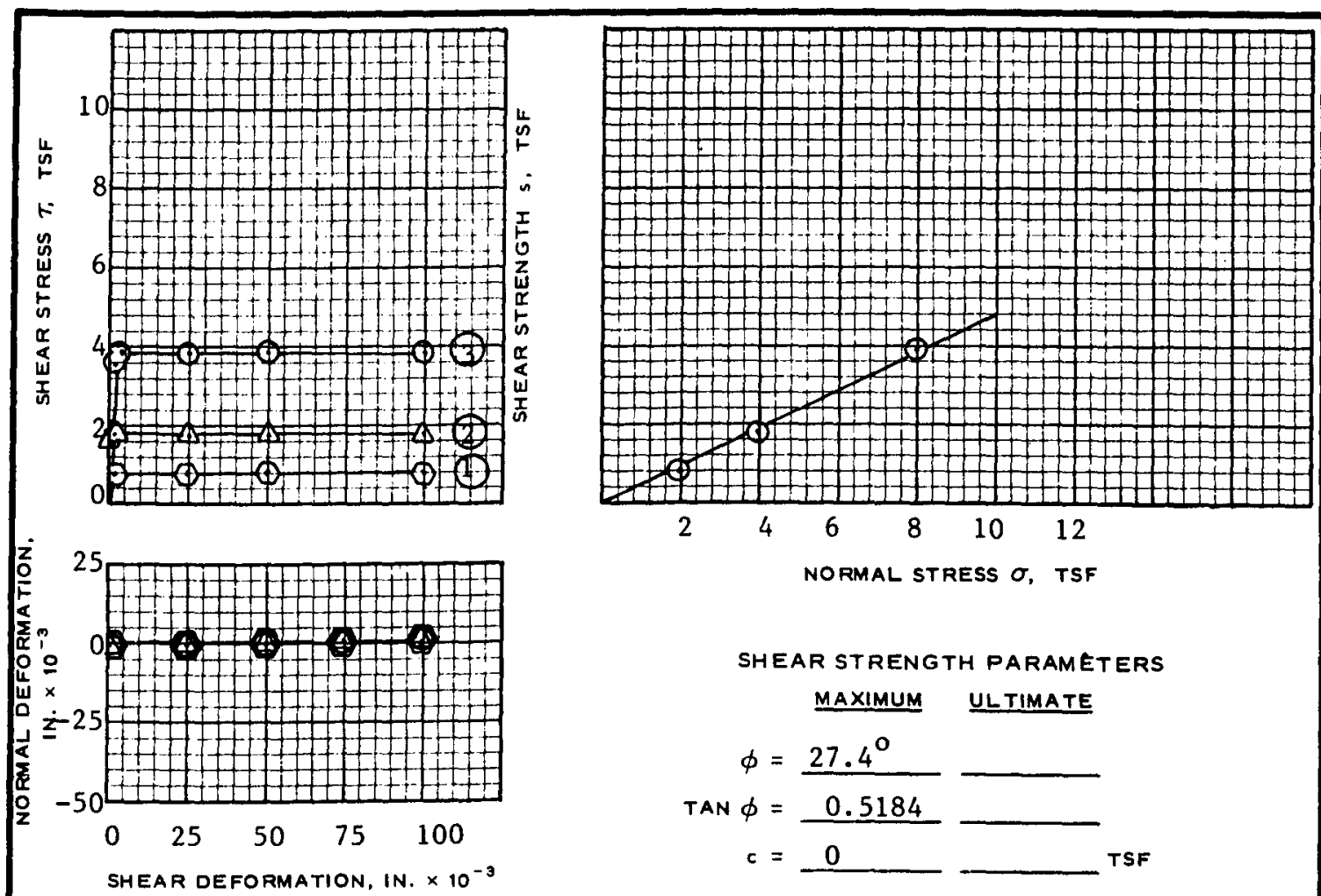

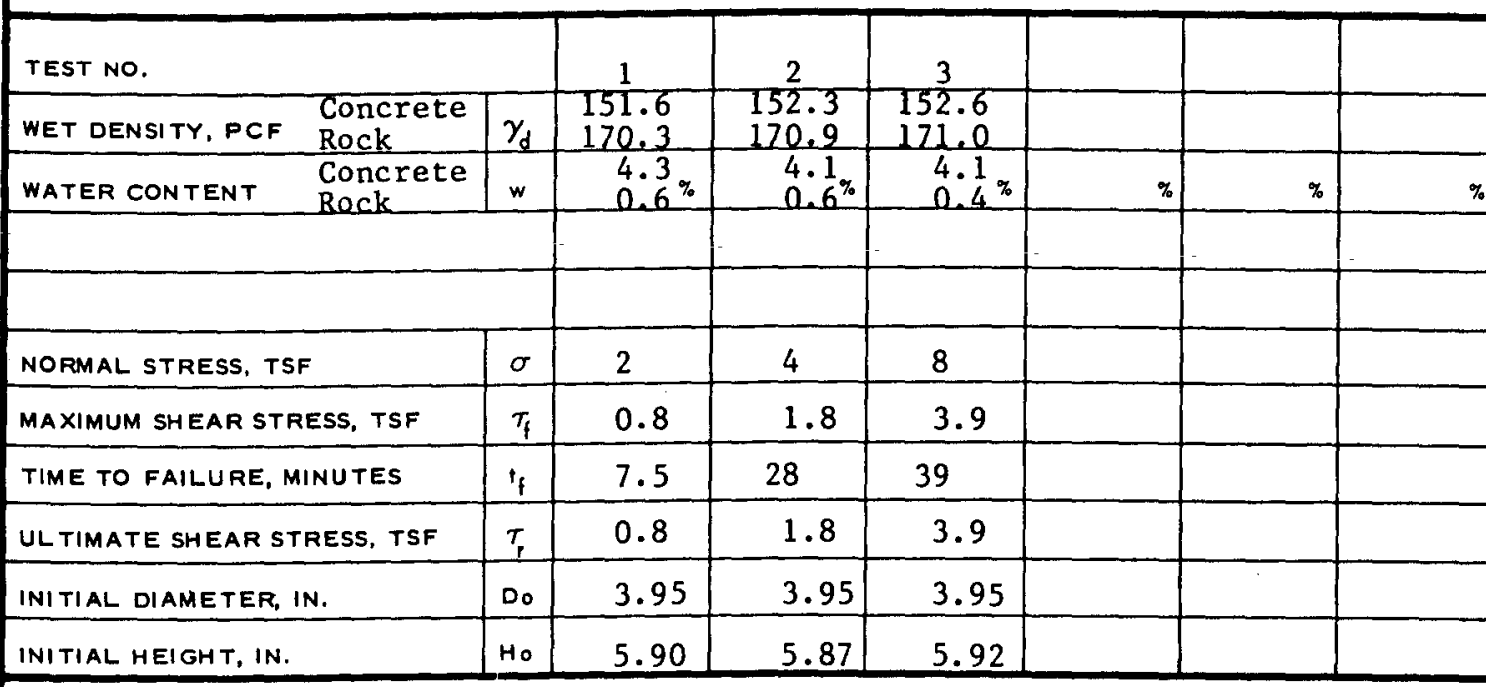

DESCRIPTION OF MATERIAL Concrete on rock (dolomite), precut

\begin{tabular}{|c|c|c|c|}
\hline $\begin{array}{l}\text { Test } \\
\text { No. }\end{array}$ & $\begin{array}{l}\text { Boring } \\
\text { No. }\end{array}$ & $\begin{array}{l}\text { Elevat } \\
\text { Concrete }\end{array}$ & $\begin{array}{l}\text { on, ft } \\
\text { Rock }\end{array}$ \\
\hline 1 & D8 80 & 577.2 & 575.5 \\
\hline 2 & D8-80 & 577.4 & 575.2 \\
\hline 3 & D8 $8-80$ & 577.6 & 575.0 \\
\hline
\end{tabular}

PROJECT DePere Lock and Dam Lower Fox River

Rate of strain $=0.004 \mathrm{in} . / \mathrm{min}$ 

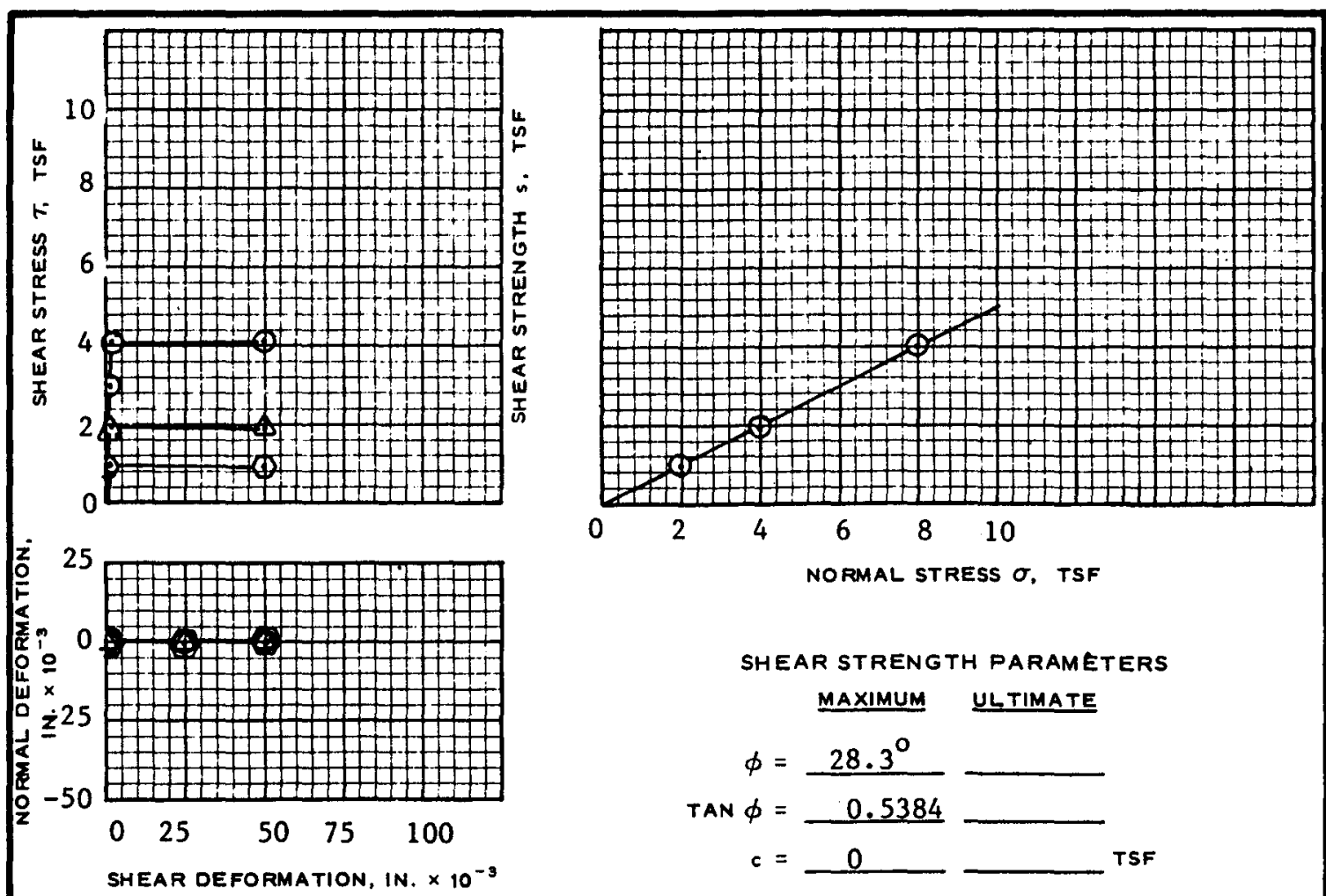

\begin{tabular}{|l|c|c|c|c|c|c|c|}
\hline \multicolumn{2}{|l|}{ TEST NO. } & 1 & 2 & 3 & & & \\
\hline WET DENSI TY, PCF & $\gamma_{d}$ & 170.9 & 170.1 & 170.6 & & & \\
\hline WATER CONTENT & $w$ & $0.6 \%$ & $0.5 \%$ & $0.6 \%$ & $\%$ & $\%$ & $\%$ \\
\hline & & & & & & & \\
\hline & & & & & & & \\
\hline NORAMAL STRESS, TSF & $\sigma$ & 2 & 4 & 8 & & & \\
\hline MAXIMUM SHEAR STRESS, TSF & $\tau_{f}$ & 0.99 & 1.98 & 4.20 & & & \\
\hline TIME TO FAILURE, MINUTES & if & 10 & 23 & 31 & & & \\
\hline UL TIMATE SHEAR STRESS, TSF & $\tau_{f}$ & 0.99 & 1.98 & 4.20 & & & \\
\hline INITIAL DIAMETER, IN. & Do & 3.95 & 3.95 & 3.95 & & & \\
\hline INITIAL HEIGHT, IN. & Ho & 5.55 & 5.53 & 5.53 & & & \\
\hline
\end{tabular}

DESCRIPTION OF MATERIAL Rock on rock (dolomite), precut

\begin{tabular}{|c|c|c|}
\hline $\begin{array}{l}\text { REM } \\
\text { Test } \\
\text { No. }\end{array}$ & $\begin{array}{l}\text { Boring } \\
\text { No. }\end{array}$ & $\begin{array}{c}\text { Elevation } \\
\mathrm{ft}\end{array}$ \\
\hline 1 & D8 -80 & 567.1 \\
\hline 2 & D8-80 & 568.4 \\
\hline 3 & D7 -80 & 569.2 \\
\hline
\end{tabular}

PROJECT DePere Lock and Dam

Lower Fox River

AREA

\begin{tabular}{|l|l} 
BORING NO. & SAMPLE NO. \\
\hline
\end{tabular}

\begin{tabular}{l|l} 
DEPTH & DATE APRII 1981 \\
\hline
\end{tabular}

DIRECT SHEAR TEST REPORT (ROCK)

WES FORM 1490 EOITION OF JUN 65 IS OBSOLETE

PLATE 25 


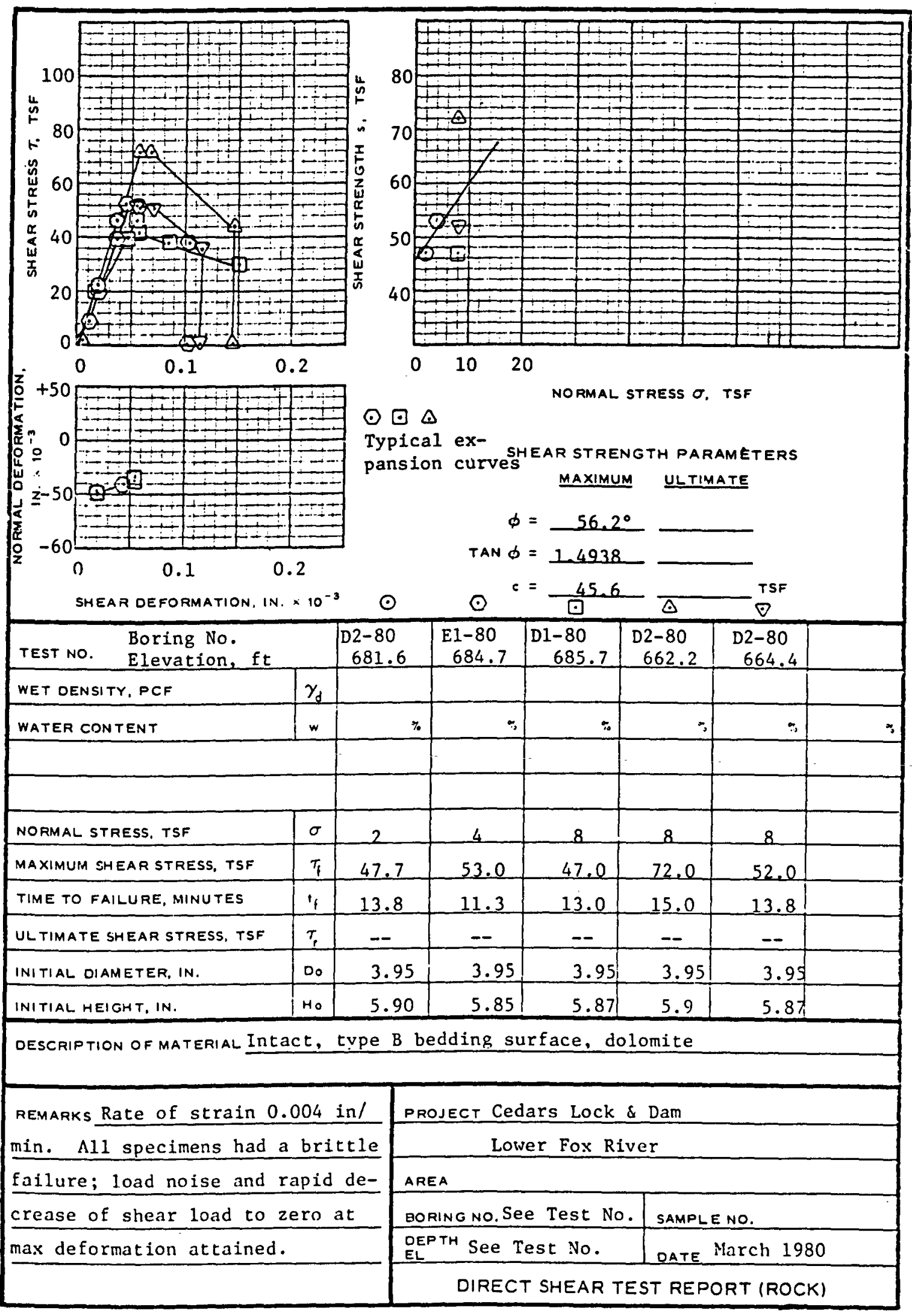

WES FORM 1490 EOITION OF JUN 65 IS OBSOLETE 
APPENDIX A

PHOTOGRAPHS OF LOCK AND DAM 


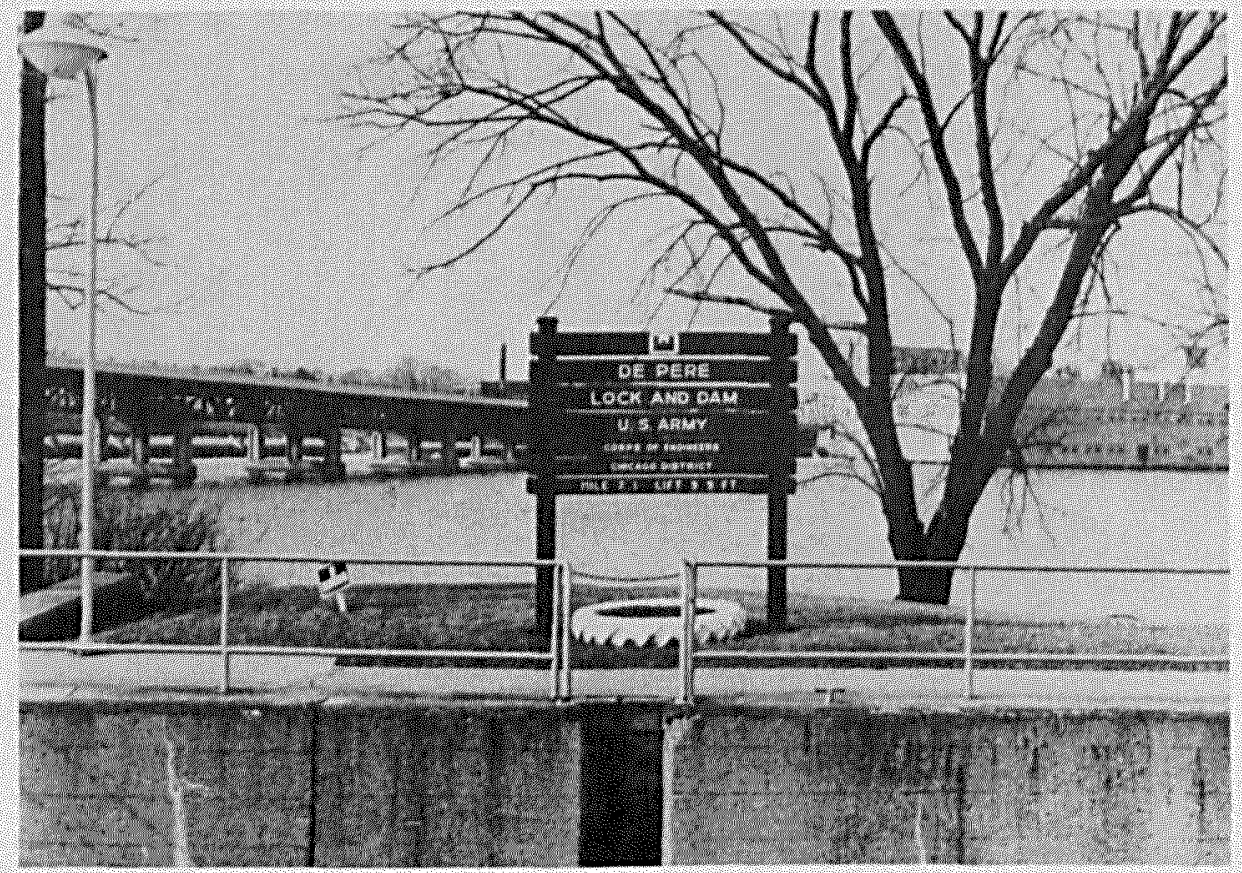

Photo 1. Project sign adjacent to upstream gate of 1 ock.

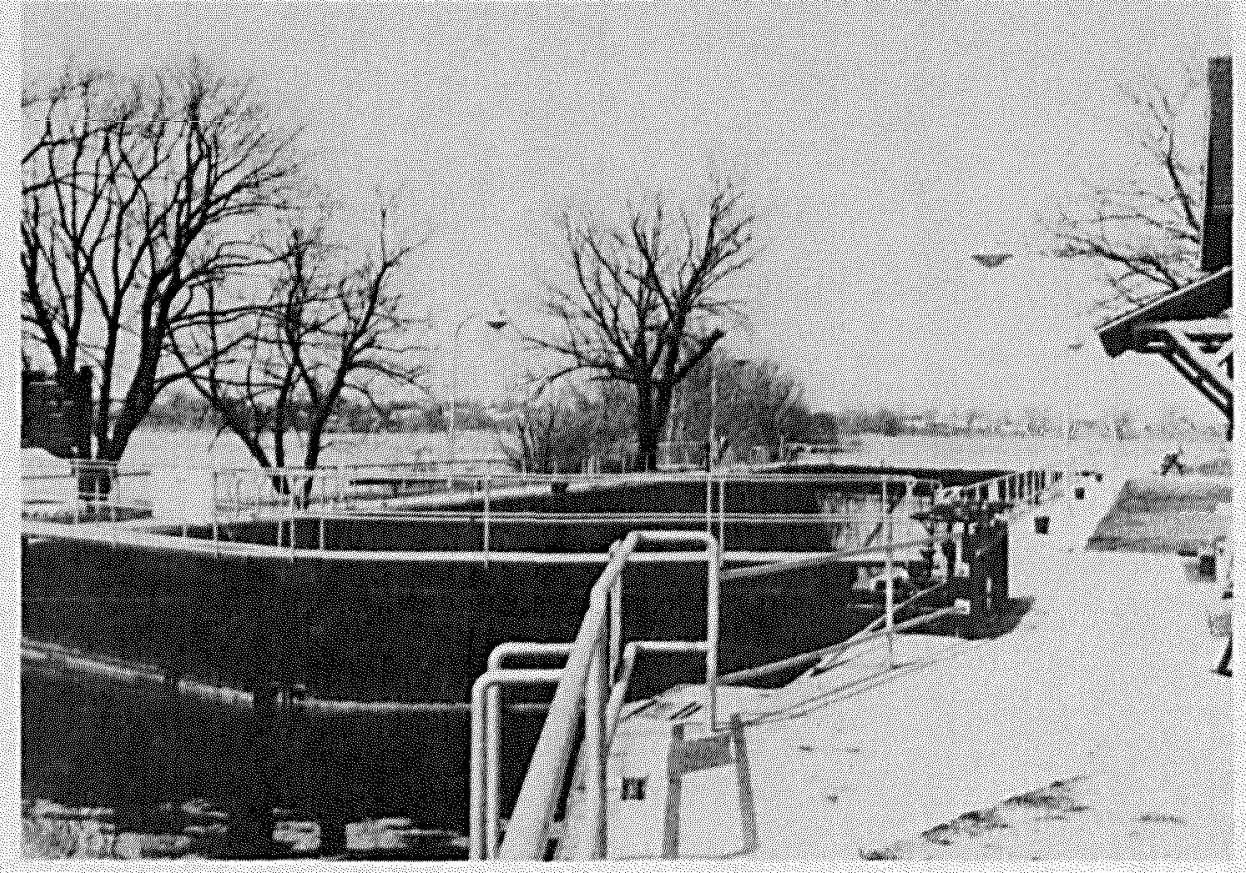

Photo 2. Taken from upstream right approach wa11 looking downstream at 1 ock. 


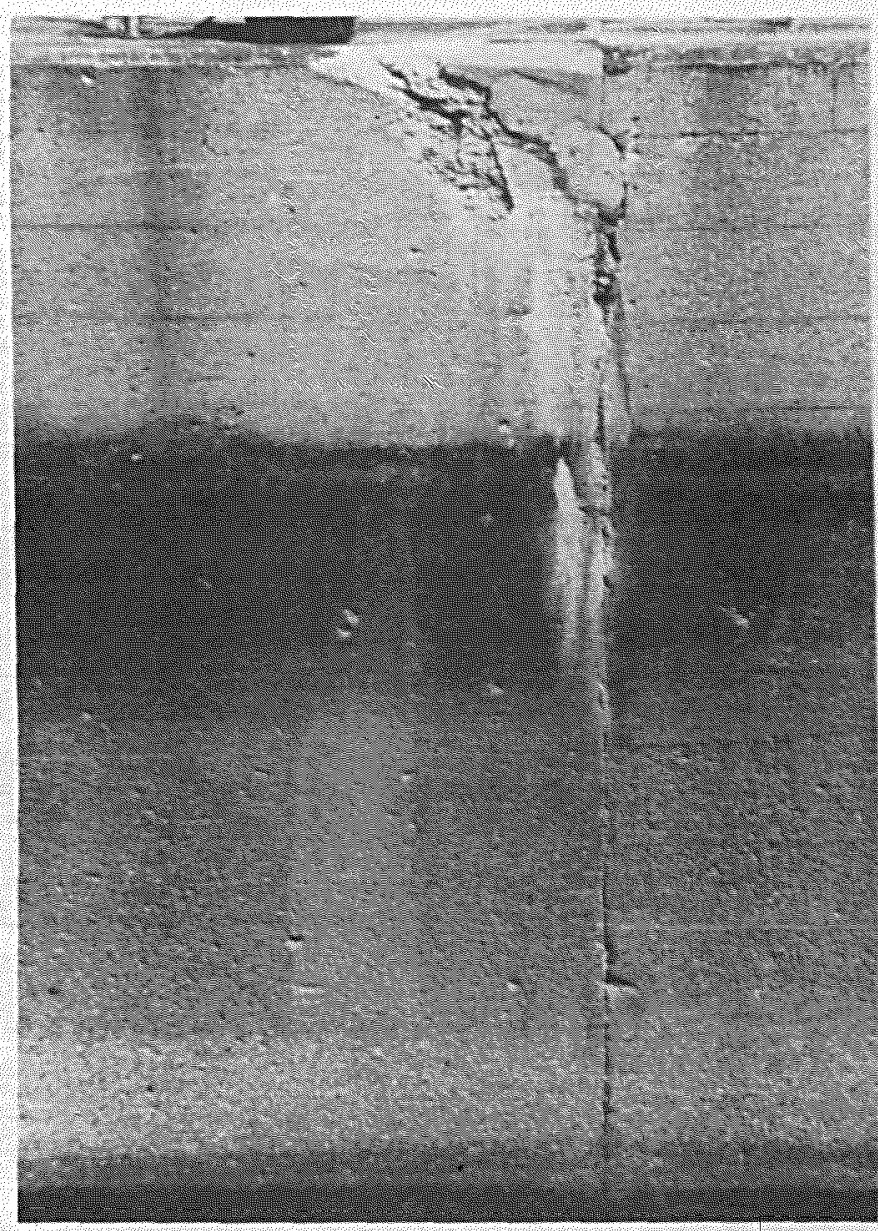

Photo 3. Taken from left 1 ock wall looking at right lock wal1. Spalling at vertical construction joint. Note pop-outs.

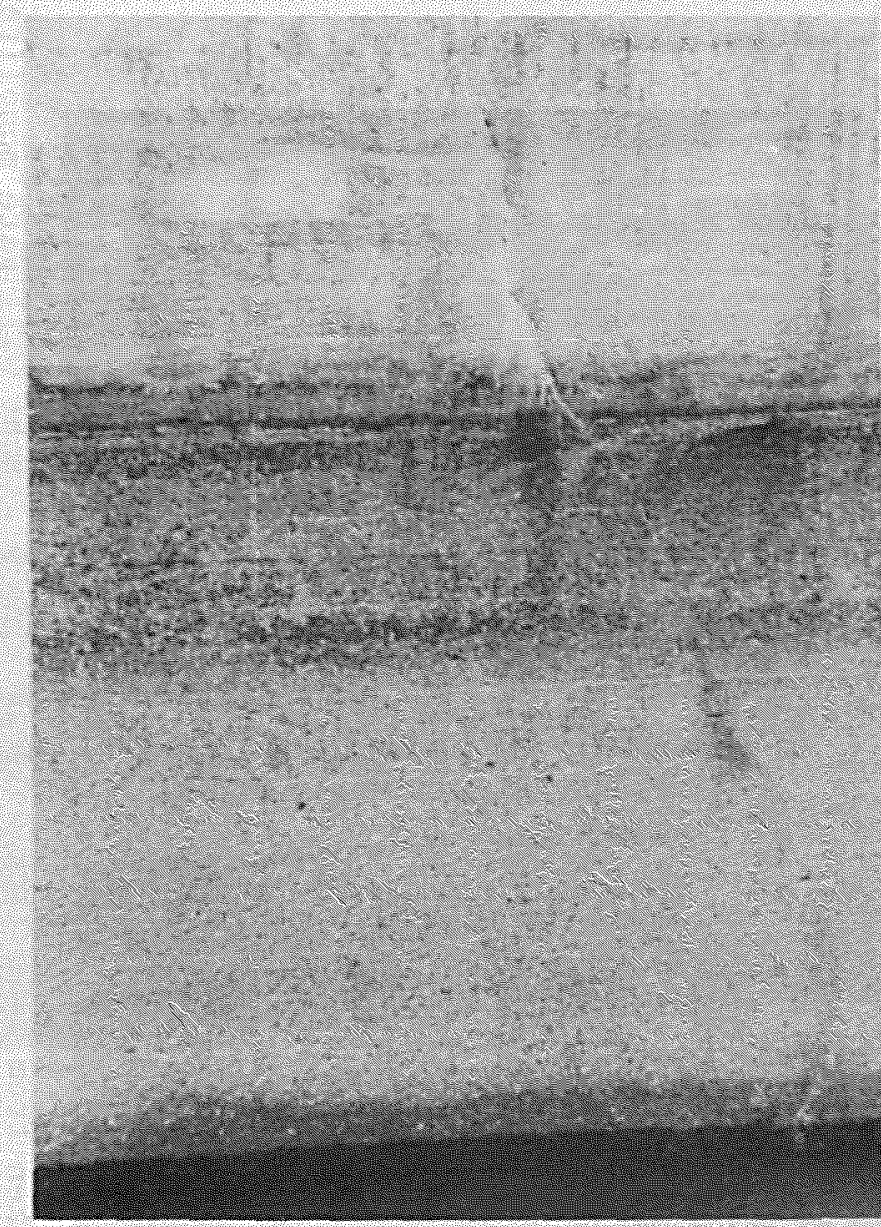

Photo 4. Taken from right 1 ock wall looking at left lock wal1. Note vertical crack and good condition of concrete surface. 


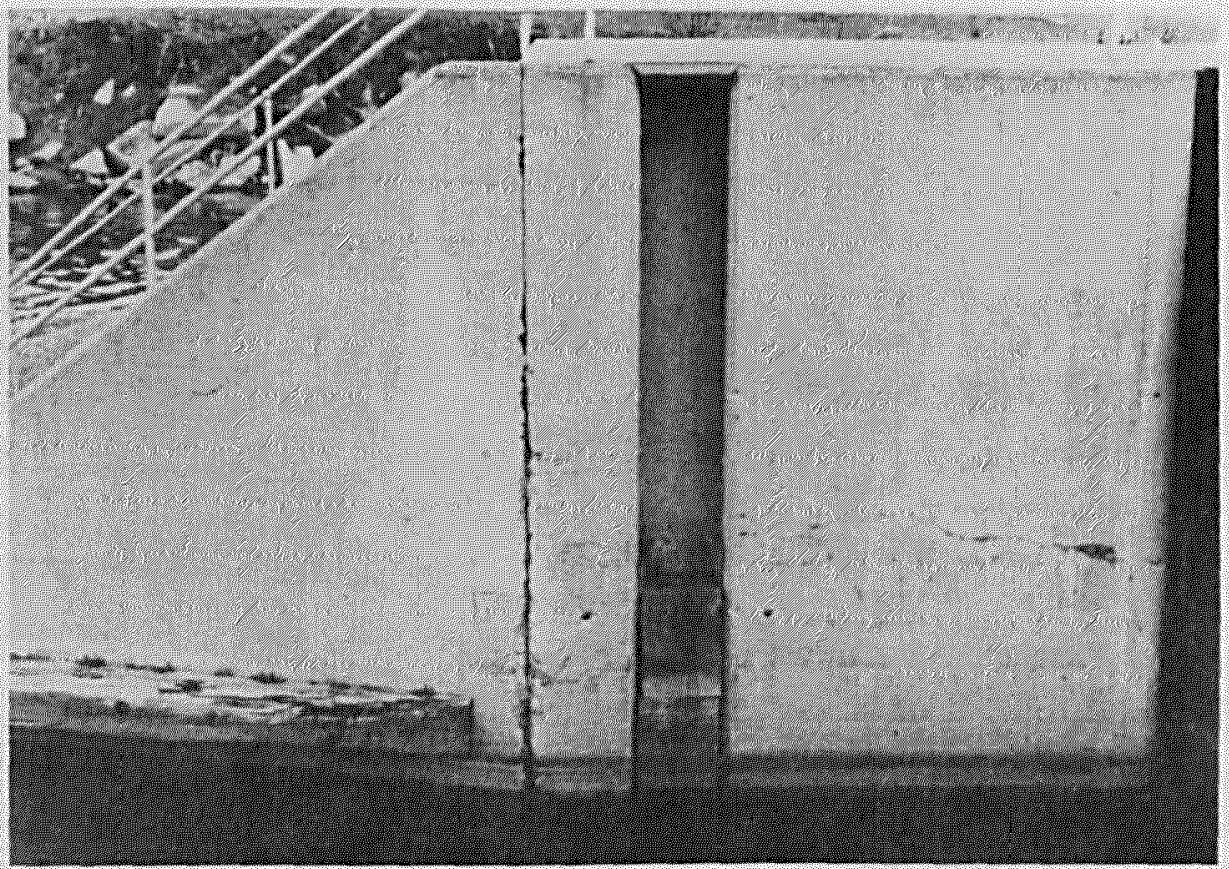

Photo 5. Taken from left lock wall looking at right wall gate monolith just downstream of gate.

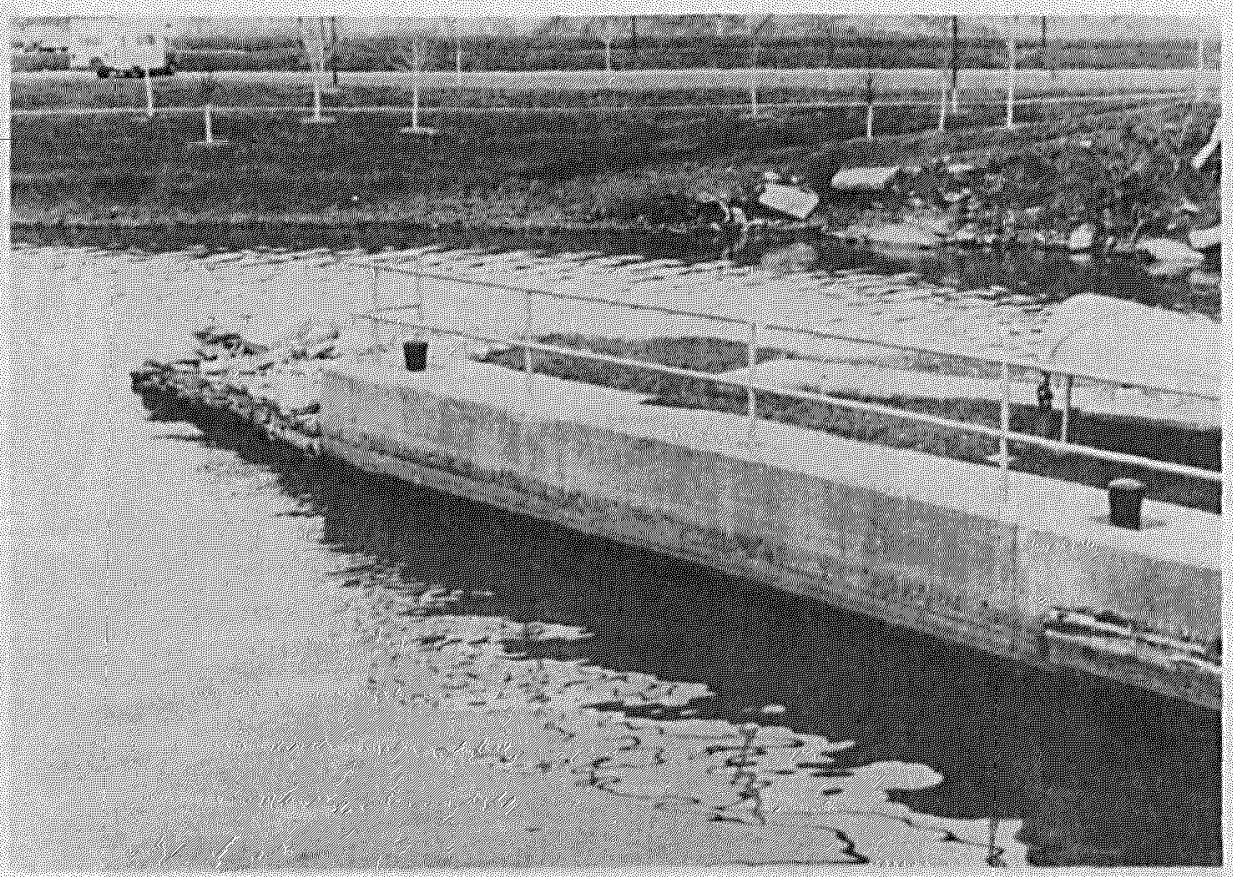

Photo 6. Taken from left lock wall looking downstream at right approach wall. Canal from a mill in background. 


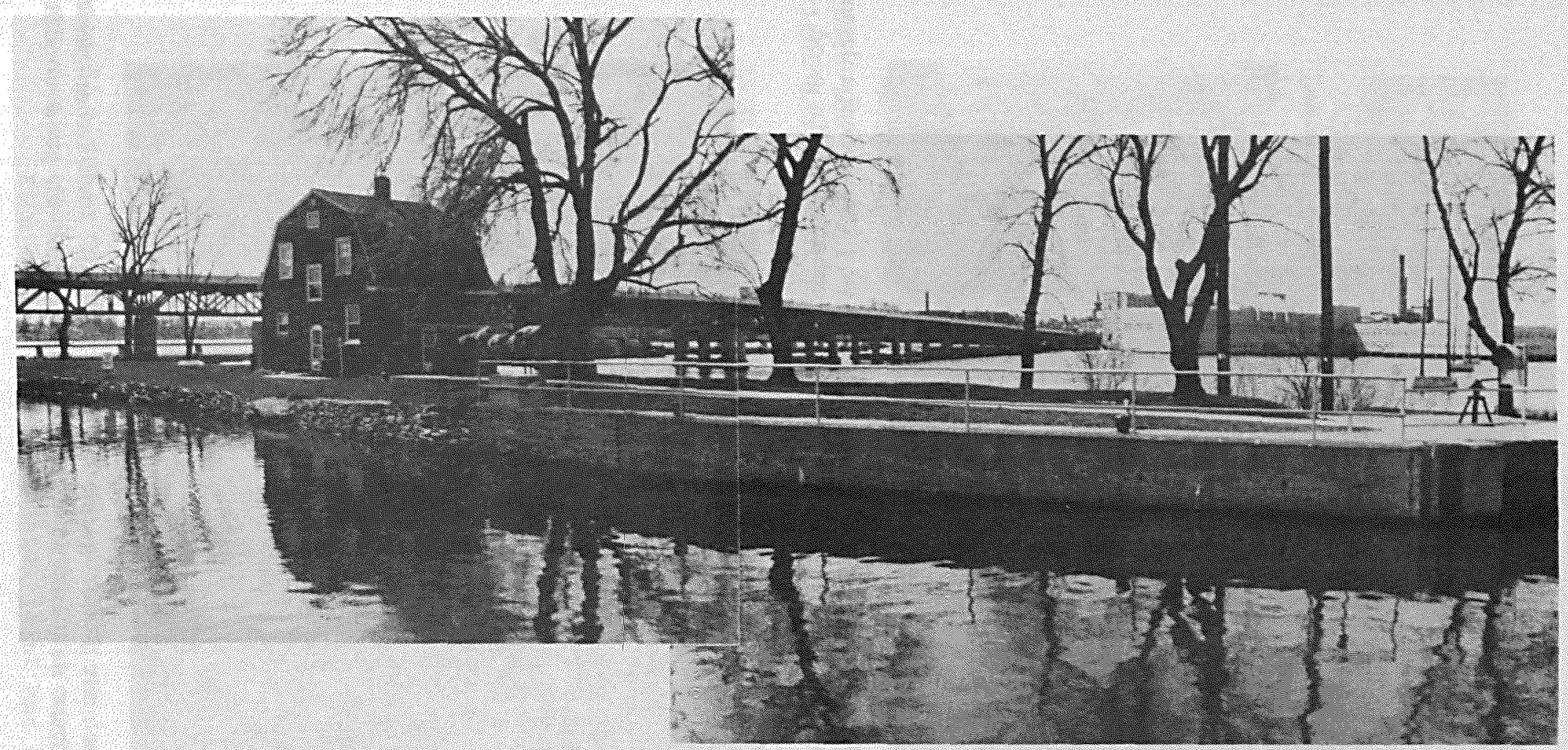

Photo 7. Taken from upstream right approach wall looking at left approach wal1. Hand crank for upstream gage visable to right of photograph. Lockmaster living quarters visable. Nicolet Paper Corporation plant can be seen across the river. 


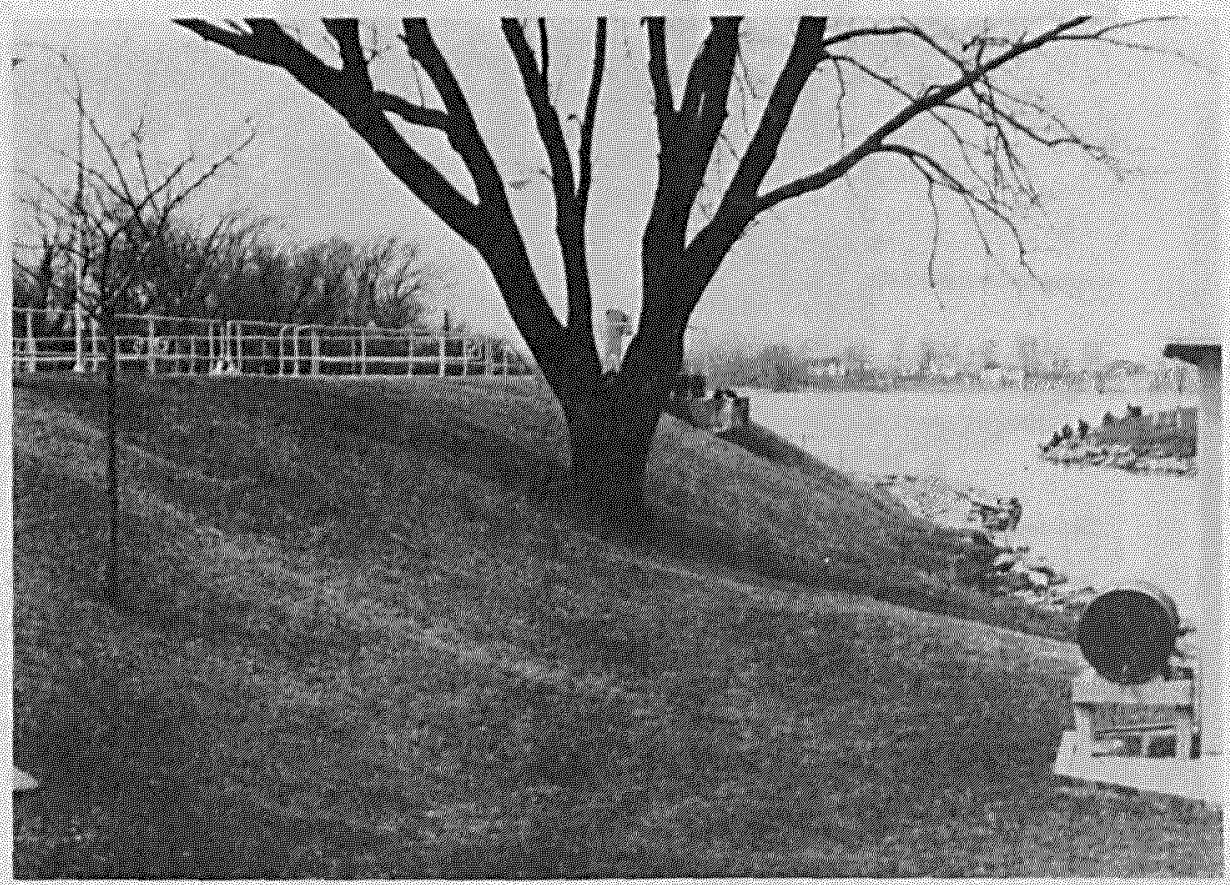

Photo 8. Taken from near upper gates on right side of lock embankment, looking downstream, minor settlement evident but embankment in good condition.

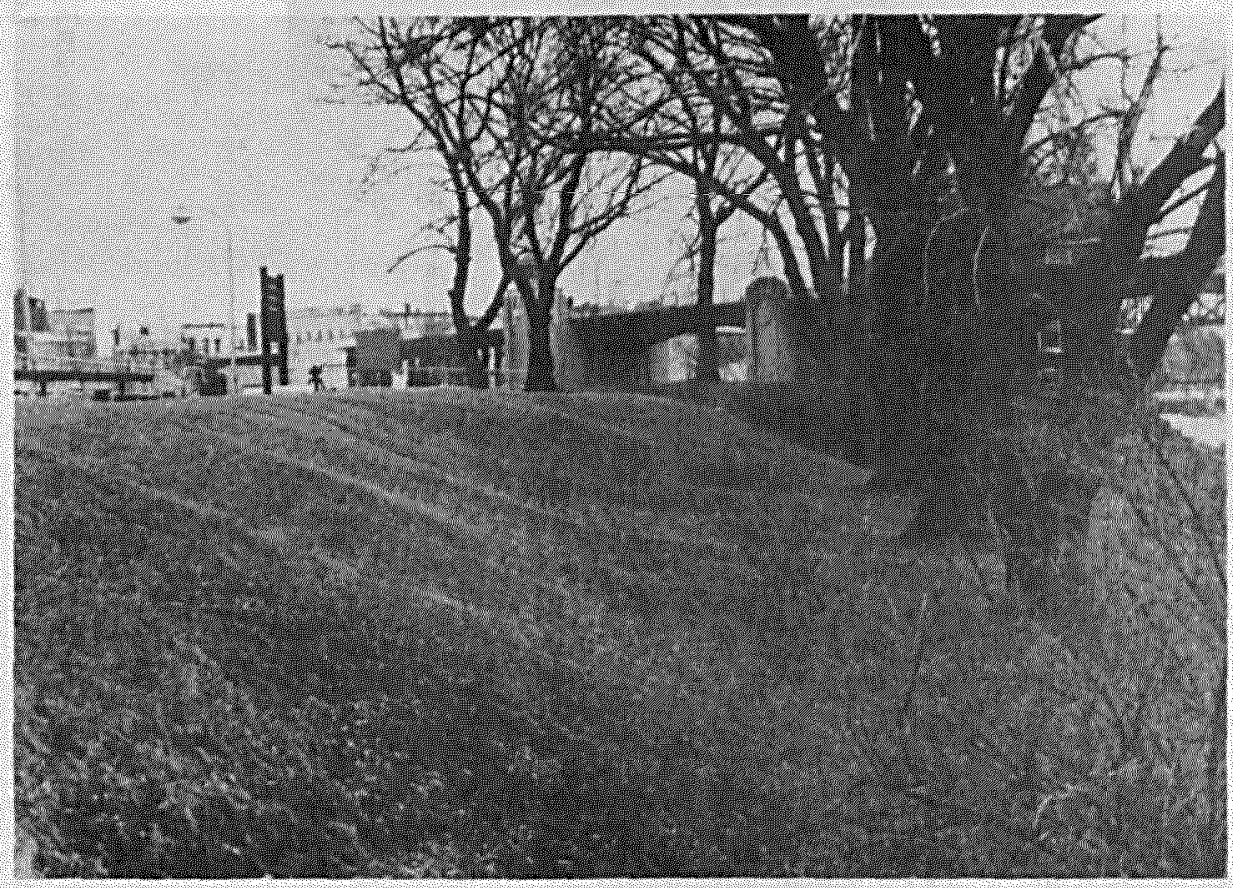

Photo 9. Taken from near lower gates on left side of lock embankment, looking upstream, minor settlement evident, embankment in good condition. 


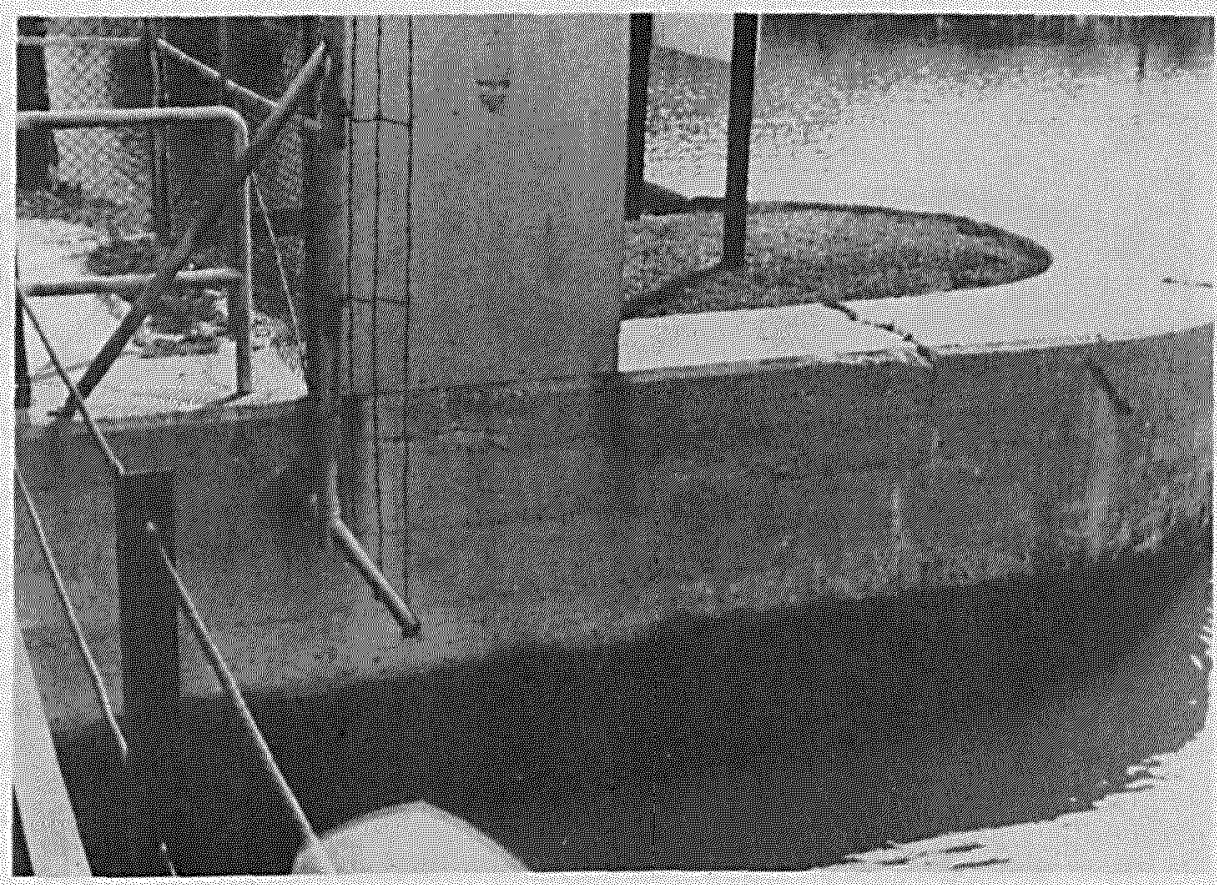

Photo 10. Taken from right spillway, looking at upstream portion of right dam abutment pier. Crack evident, concrete in good condition.

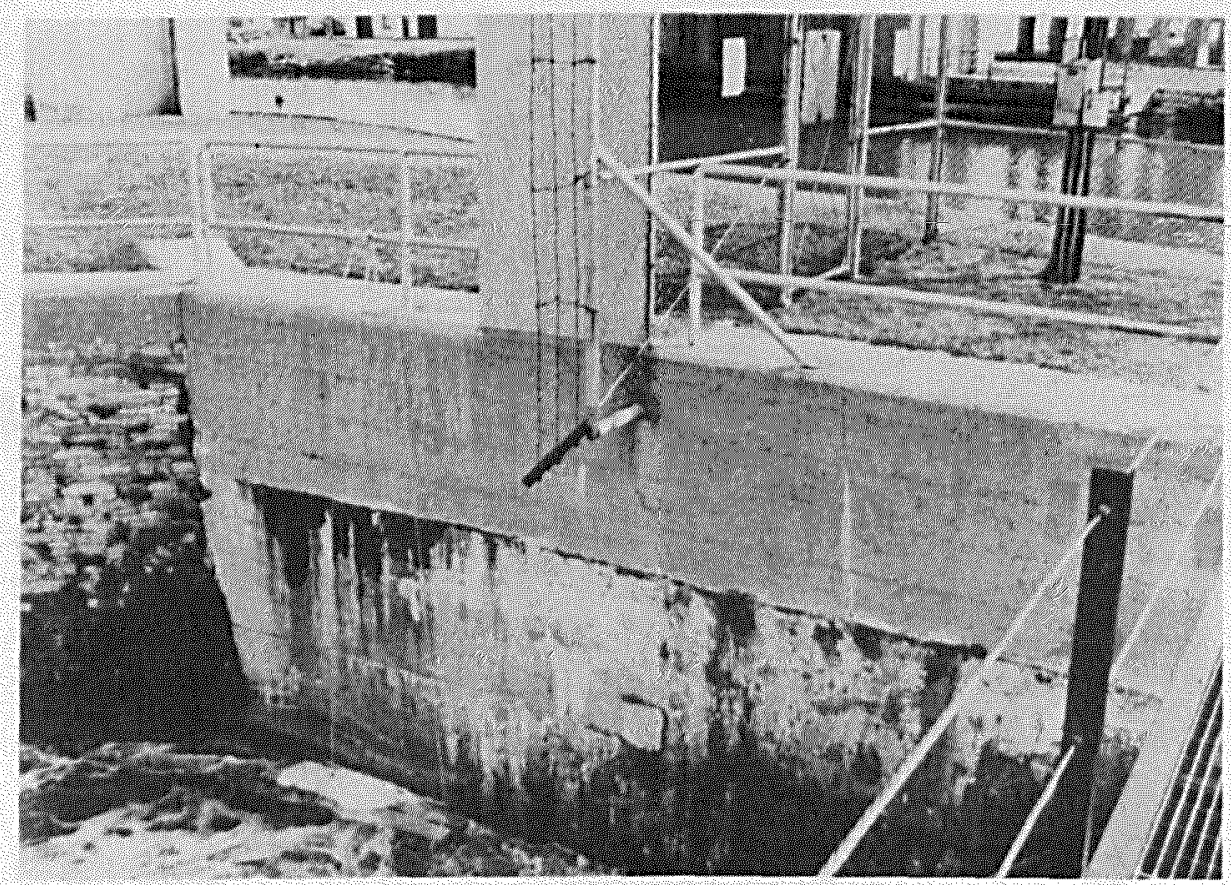

Photo 11. Taken from right spillway, looking at downstream portion of right dam abutment pier. Top concrete in good condition. White exudation coming from horizontal joint and cracks. 


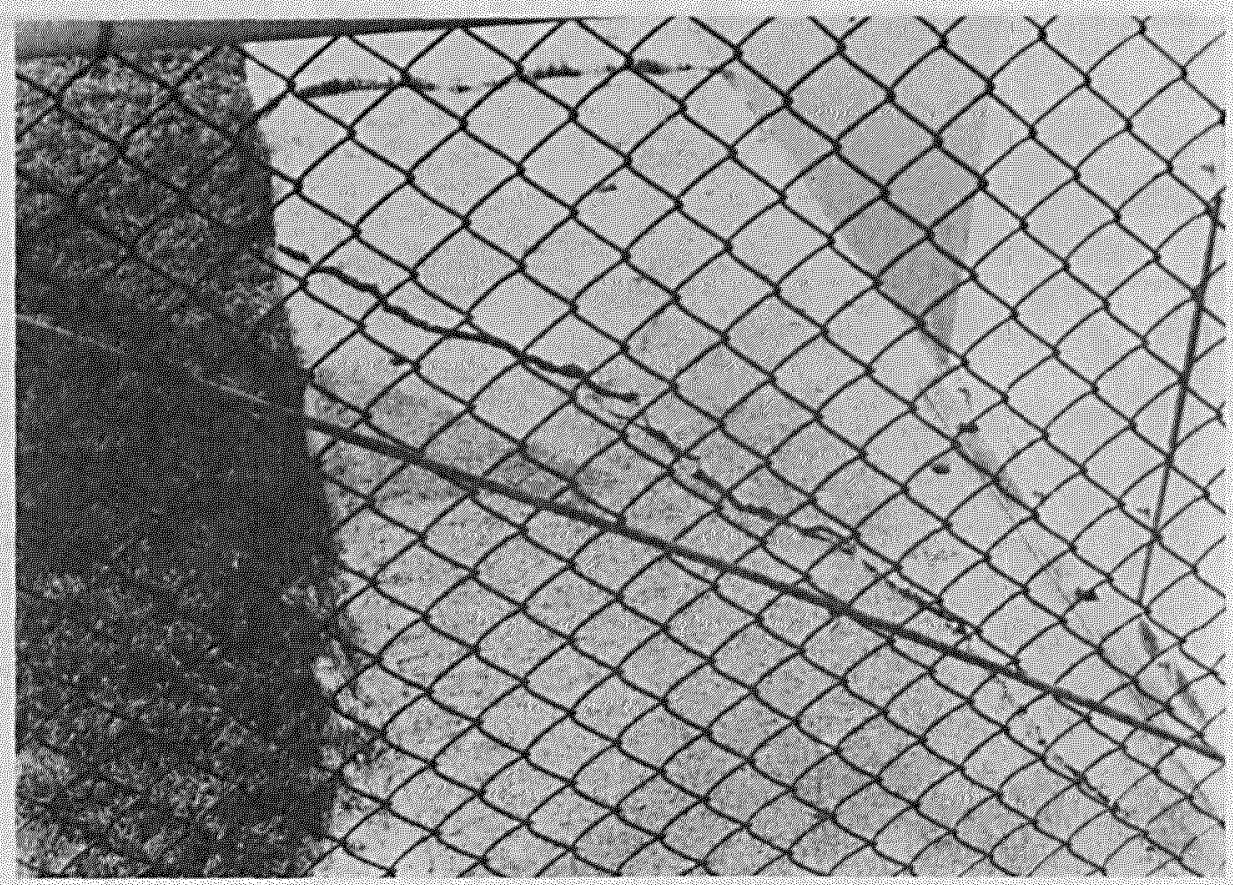

Photo 12. Taken from right abutment, looking upstream at wide crack on top of abutment pier. Cracked section of concrete appears raised.

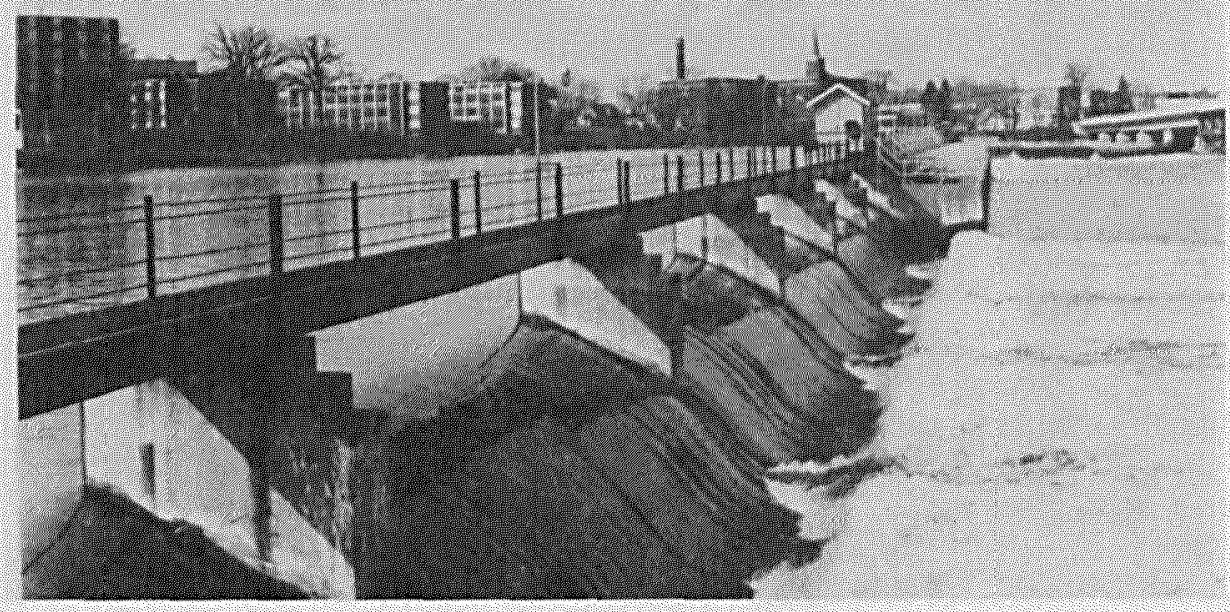

Photo 13. Taken from right dam abutment, looking across right spillway. Minor amount of white exudation and cracking; spillway pier No. 1. 


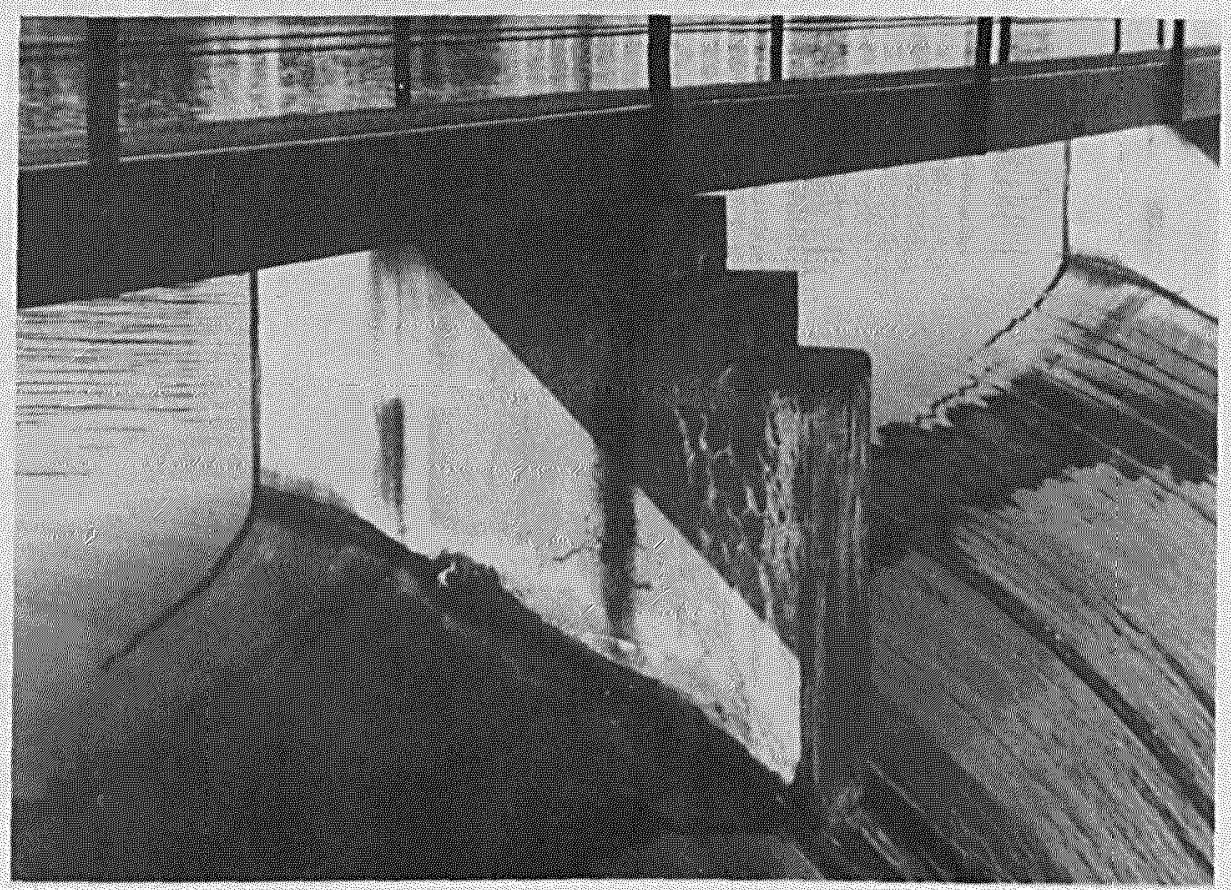

Photo 14. Taken from same location as Photo 12. Close-up of spillway pier No. 1. Boring D WES D7-80 was drilled through pier.

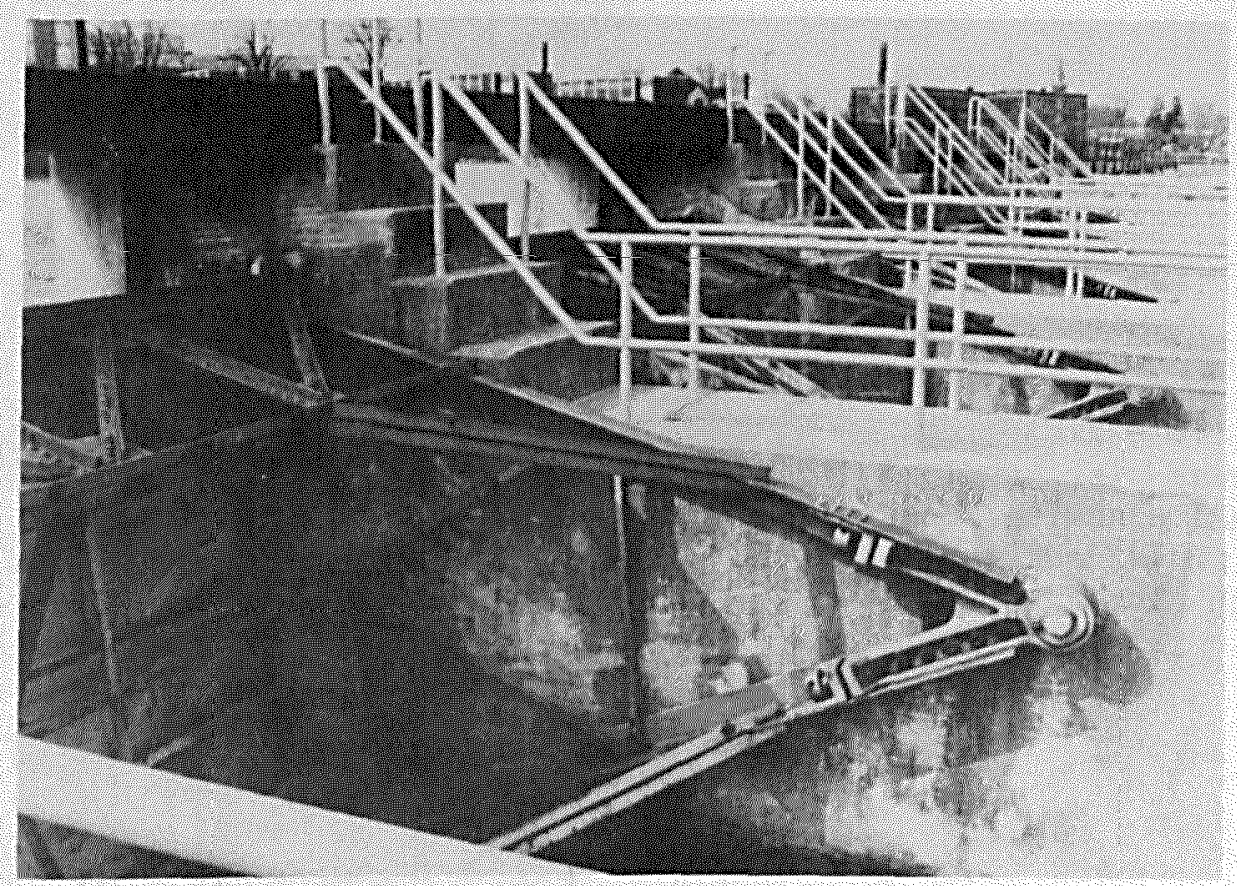

Photo 15. Taken from sluiceway pier No. 10, looking upstream. Except for local cracking and exudation, concrete is in generally good condition. 


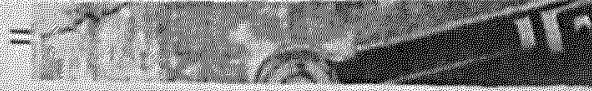

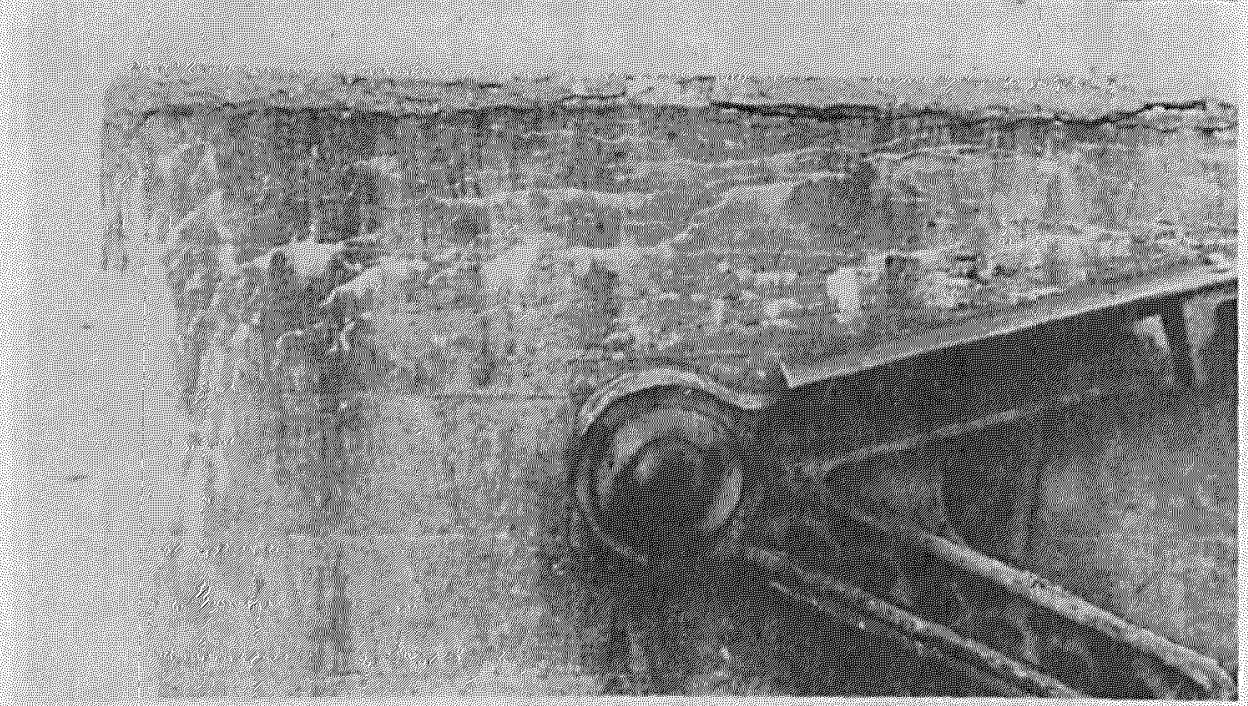

Photo 16. Taken from sluiceway pier, cracking is typical of freeze-thaw action; white exudation present at cracks.

photo 17. Taken from sluiceway pier, typical diagonal cracking from hinge pin, cracks go through piers.

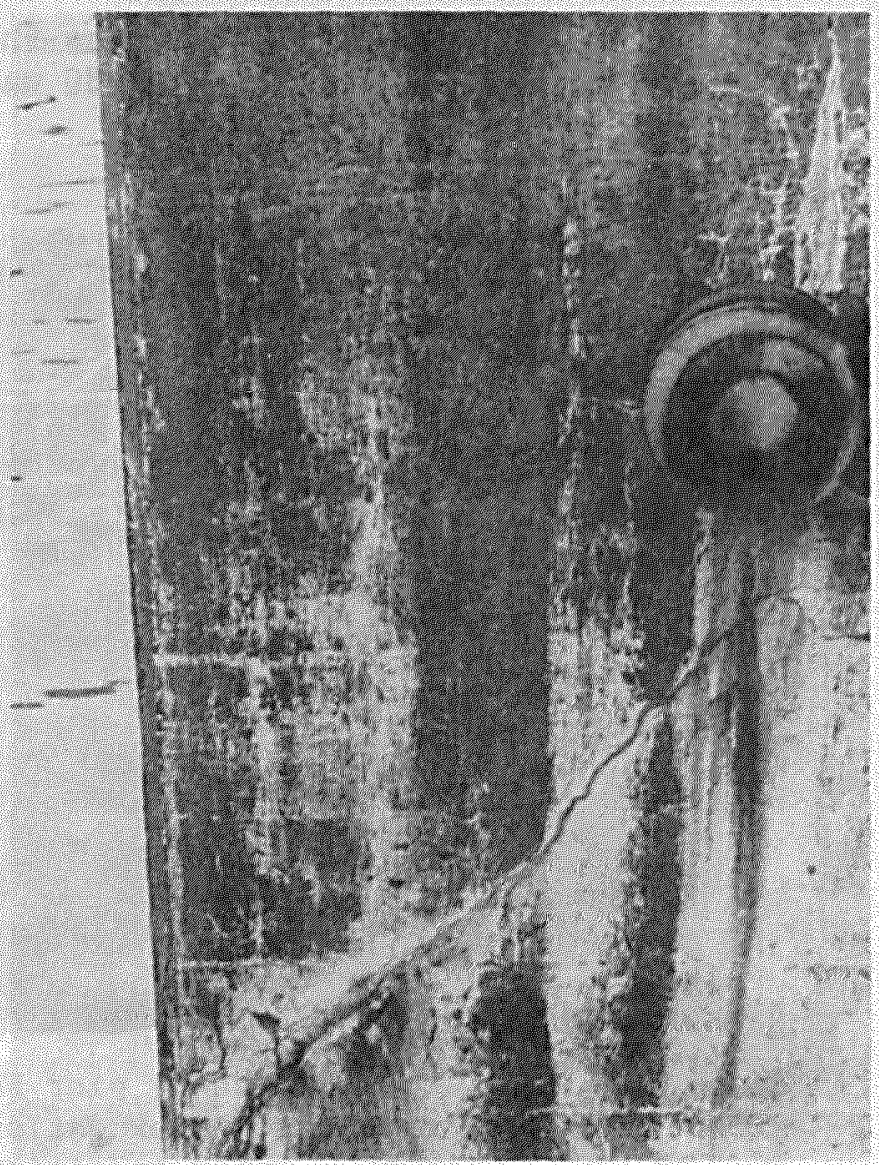




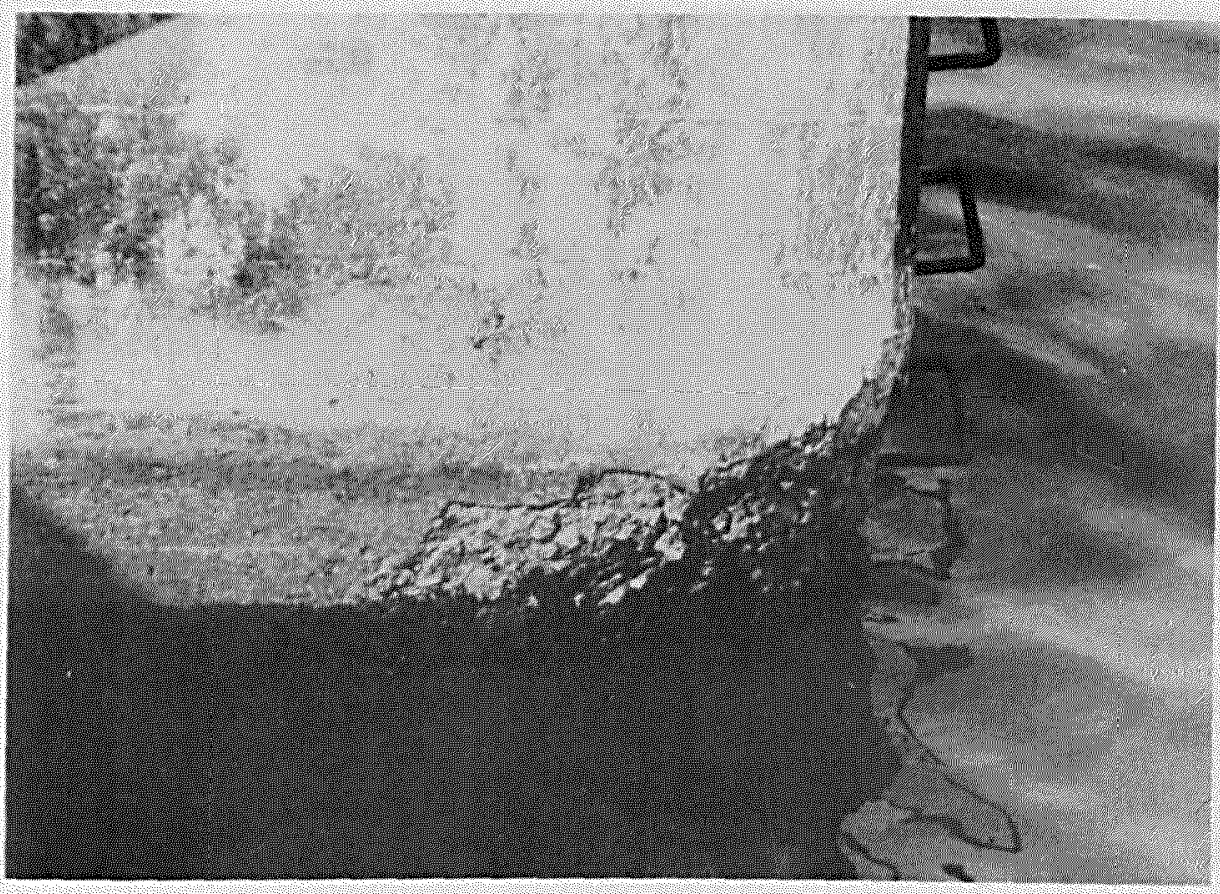

Photo 18. Taken from sluiceway pier, looking downstream, erosion of concrete near low pool elevation.

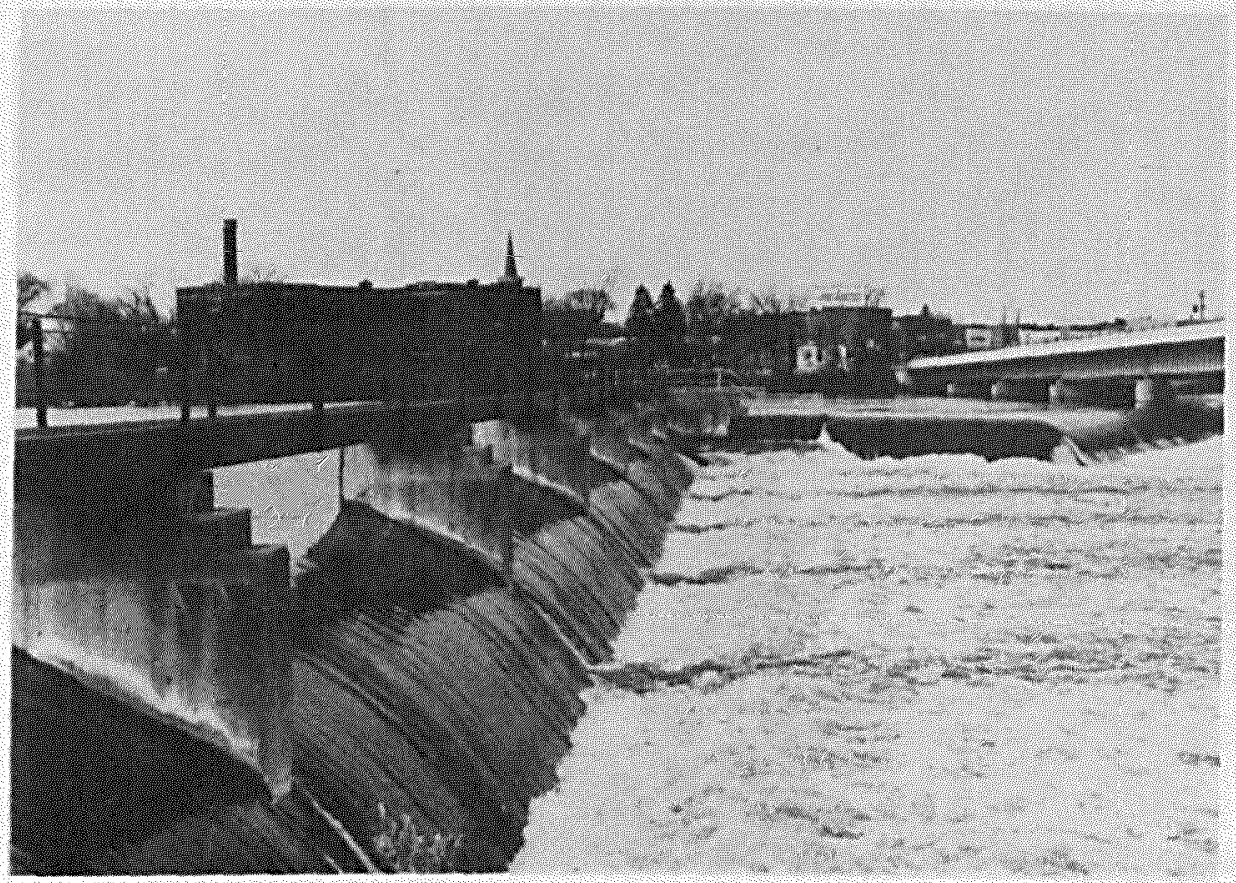

Photo 19. Taken from sluiceway pier No. 15, 1ooking across left spillway, concrete in pier in good condition. Private dam seen just downstream of left abutment. 


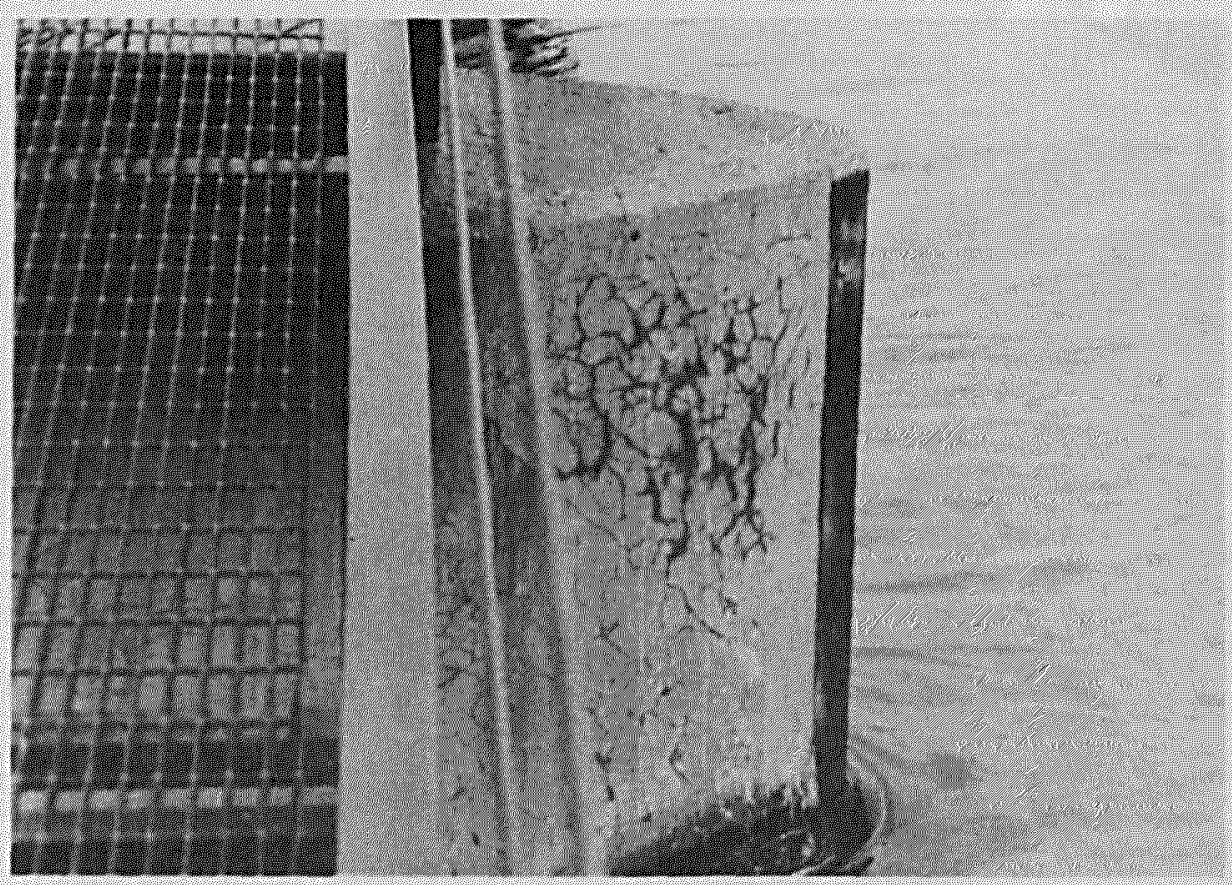

Photo 20. Taken from left spil1way, looking upstream at nose of pier, pattern cracking with water seeping from cracks causing the cracks to appear dark brown.

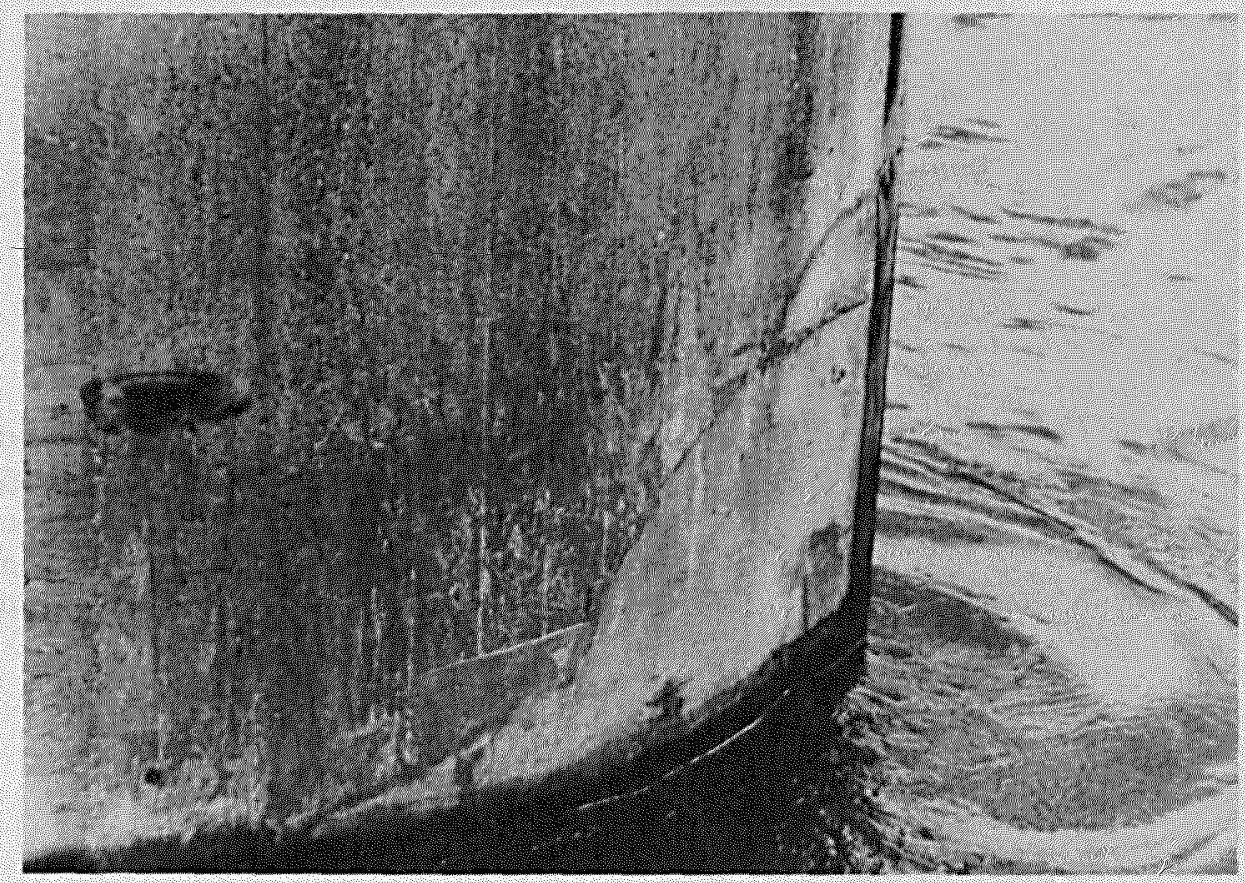

Photo 21. Taken from left spillway, 1ooking upstream at walkway pier, patched concrete in good condition. 


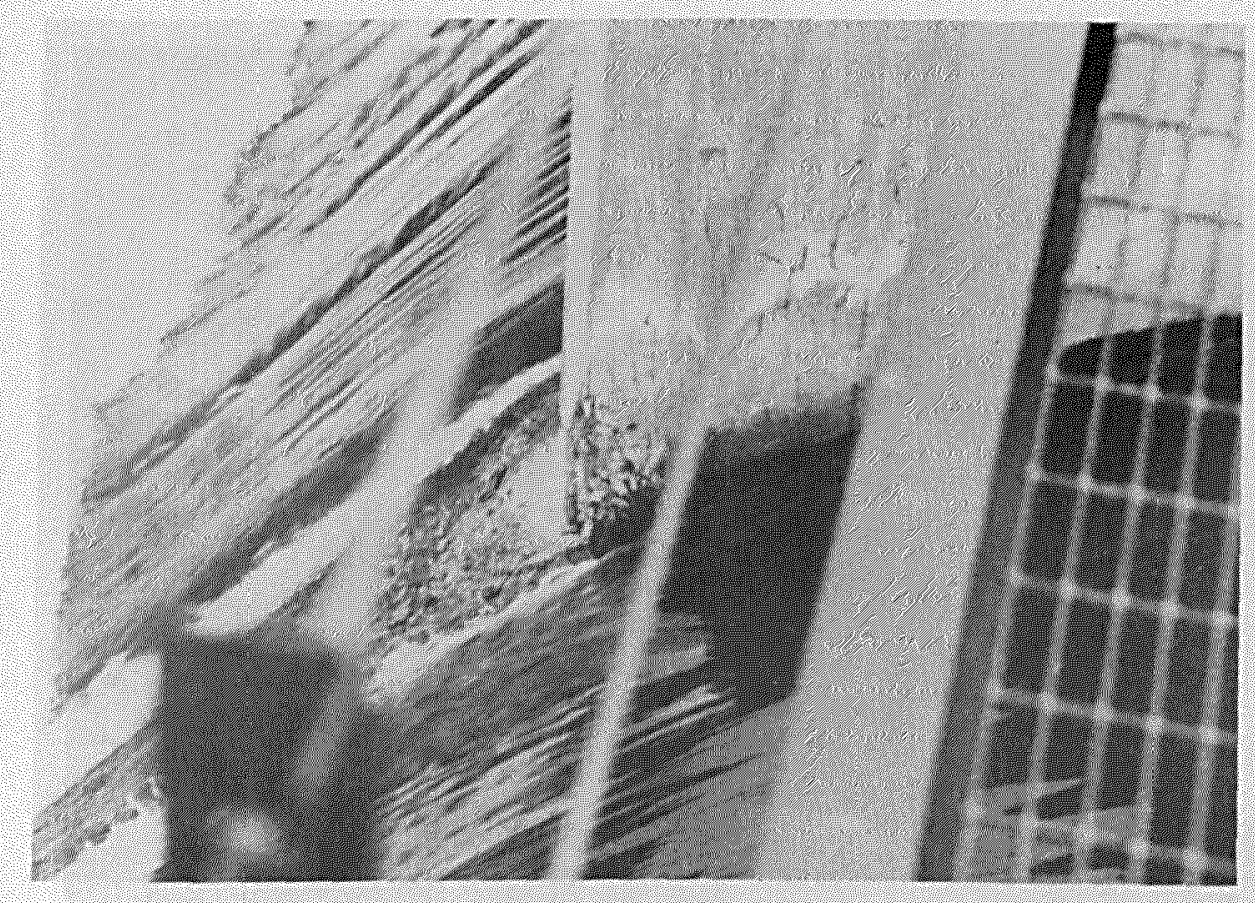

Photo 22. Taken from left spillway, looking at downstream portion of walkway pier, light erosion at waterline.

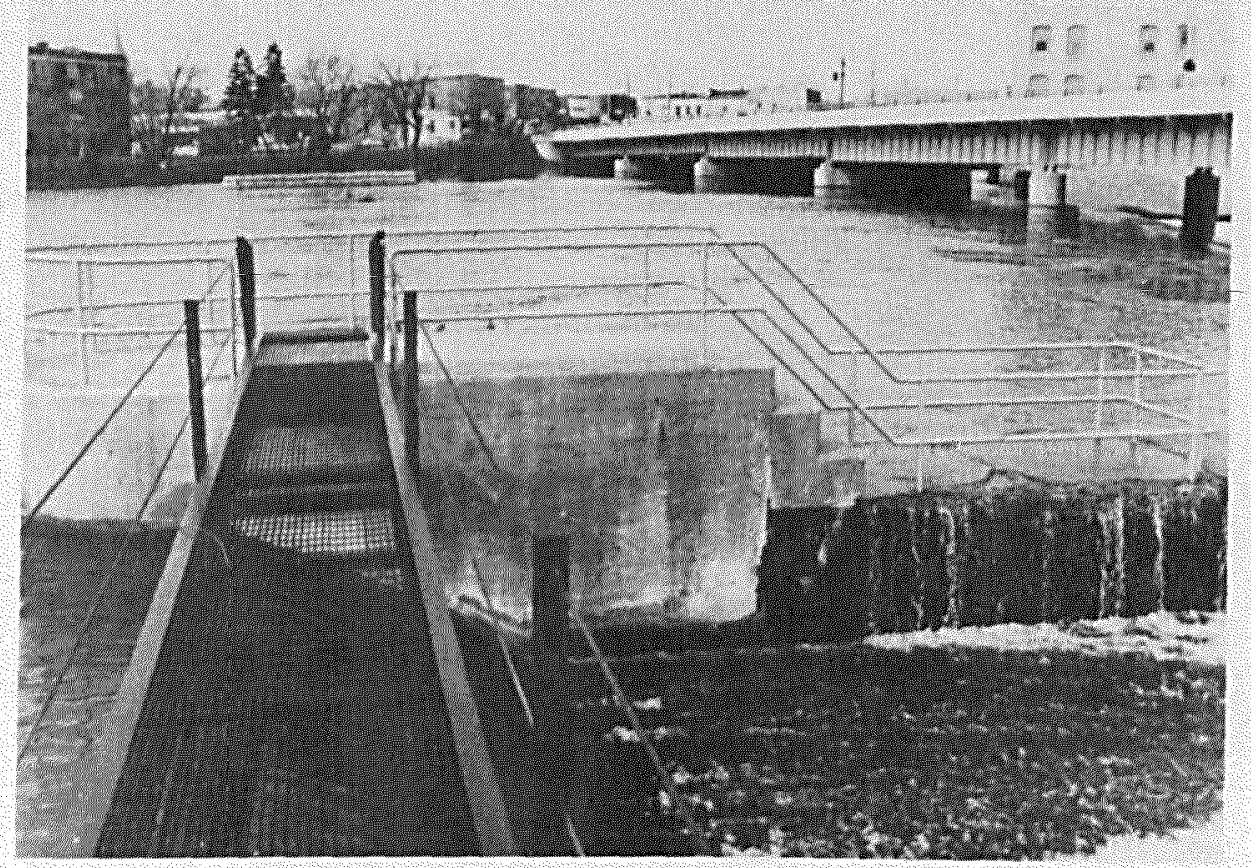

Photo 23. Taken from left spillway, looking at left dam abutment pier. 


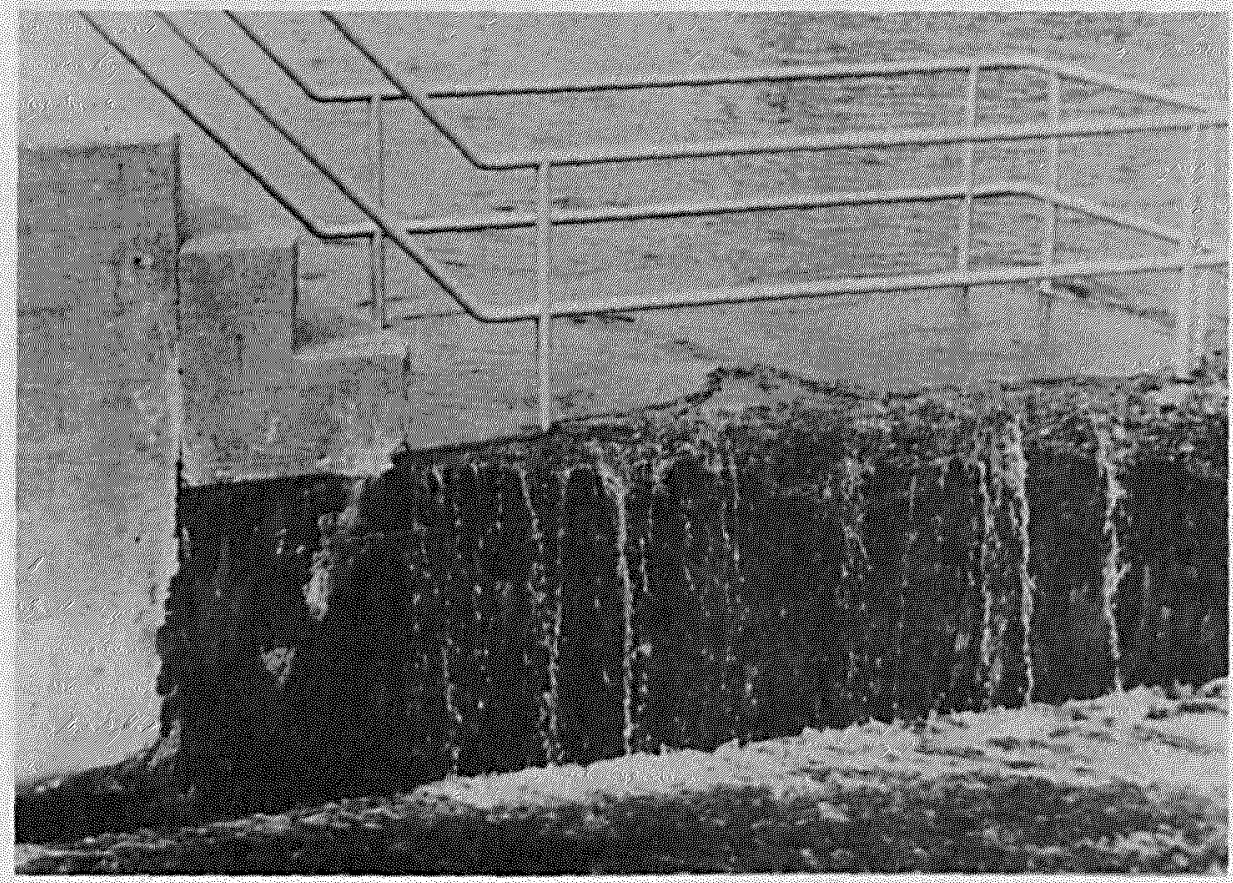

Photo 24. Close-up of downstream end of left abutment pier. 
APPENDIX B

DRILLING LOGS

NOTE: Field boring logs identify bedrock as limestone; subsequent petrographic examination showed the bedrock to be dolomite. 
Hele No. DWES-LI EC

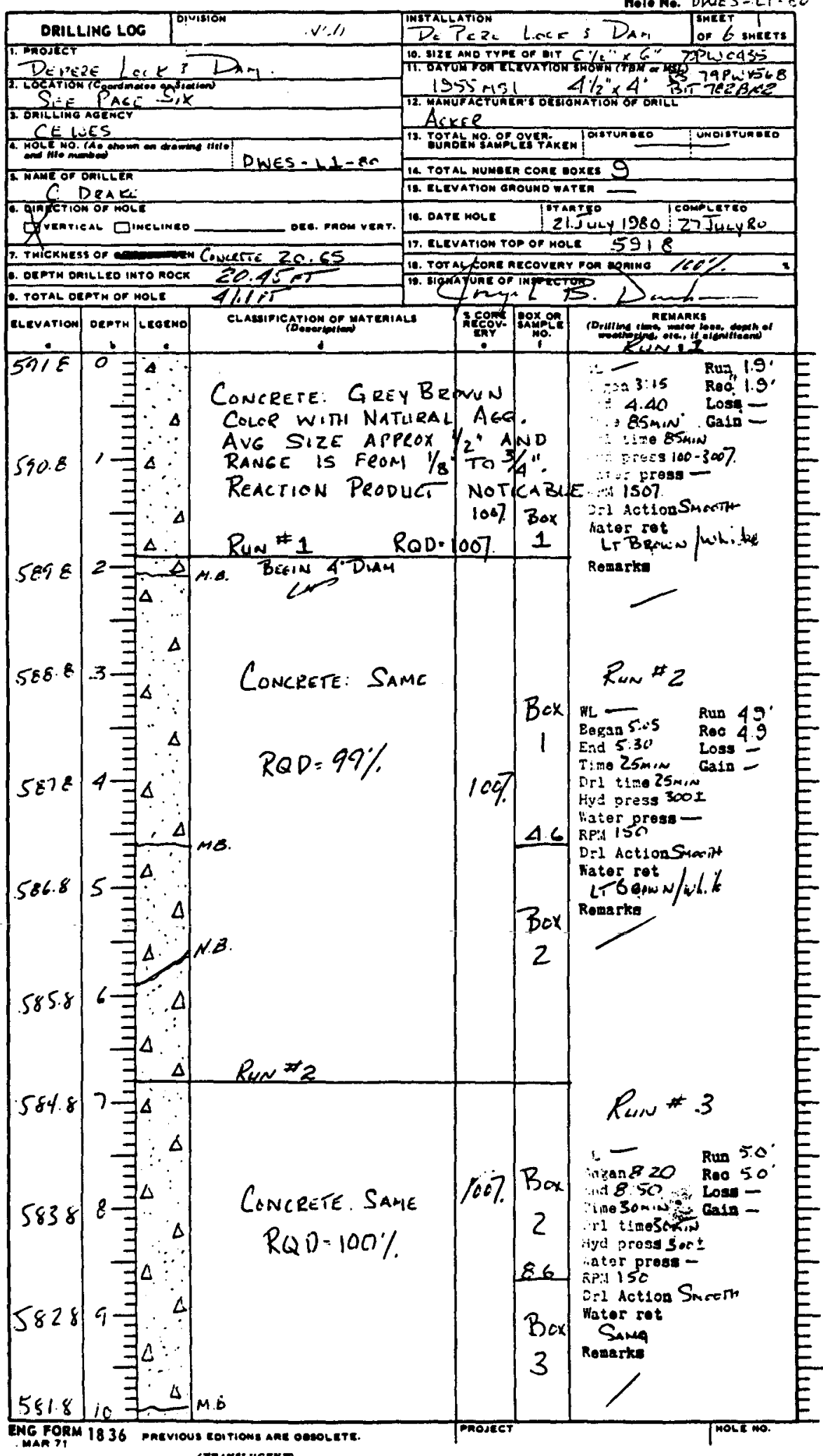


Hole Ne. $1-j-8 C$

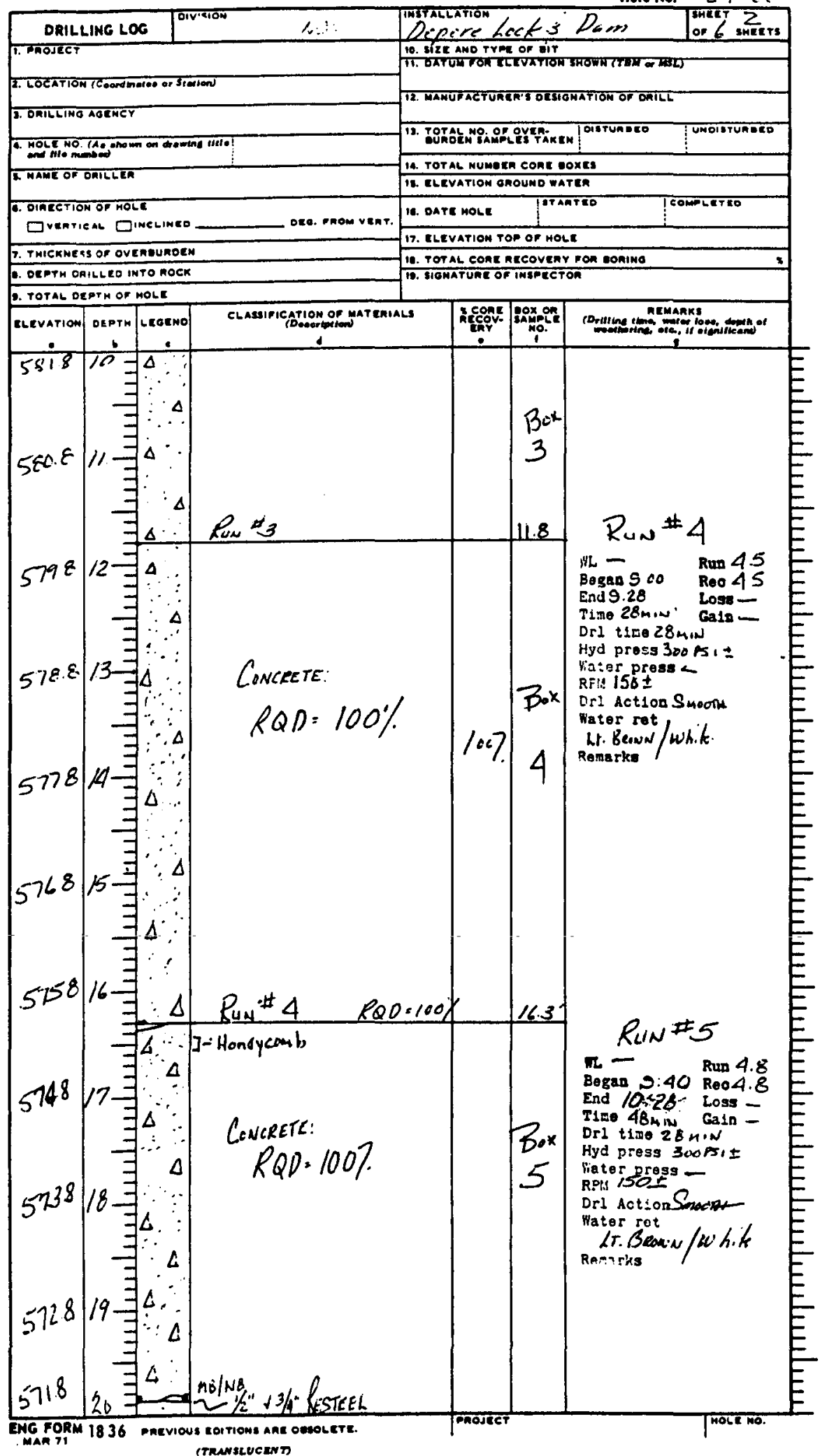




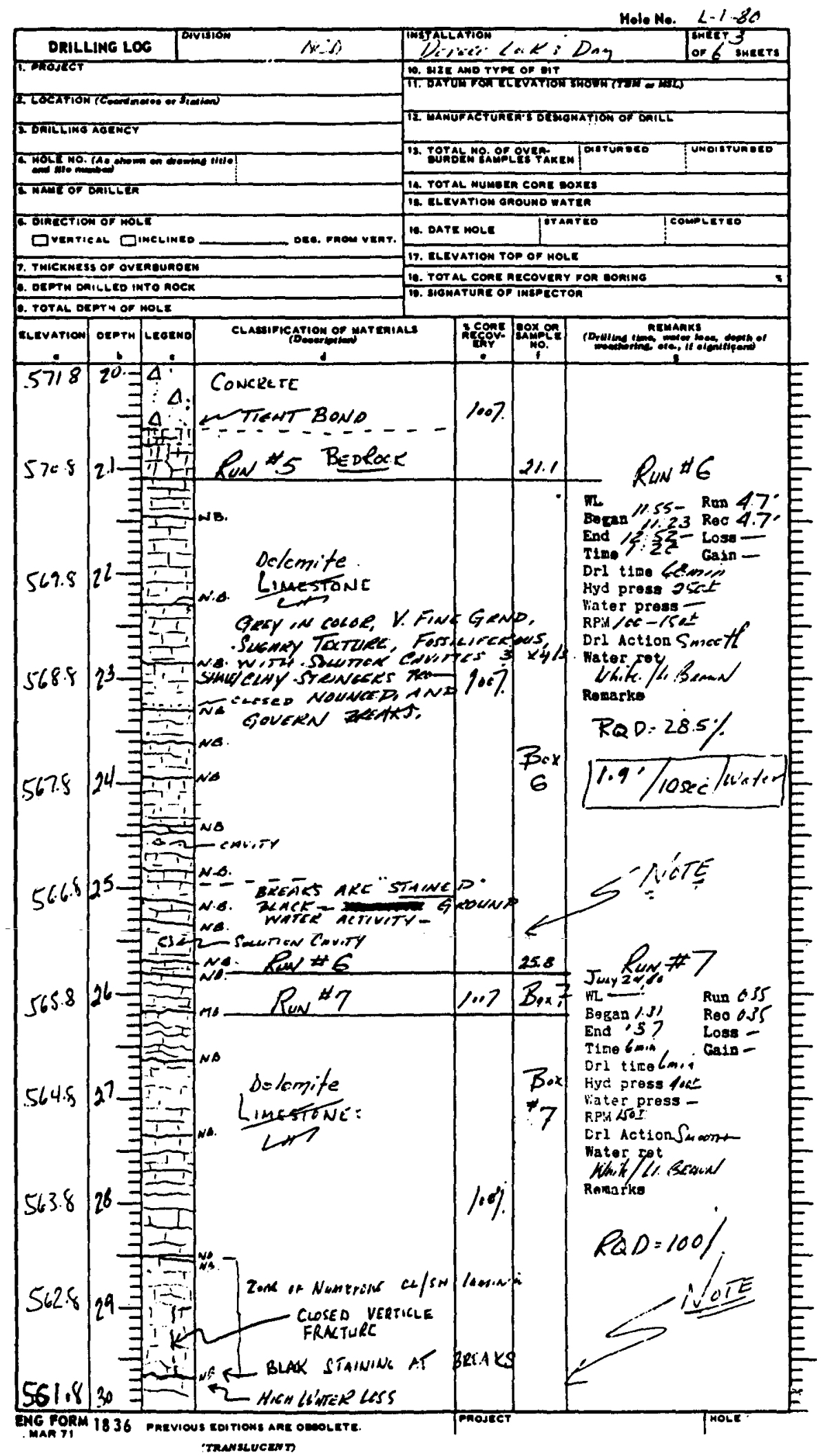




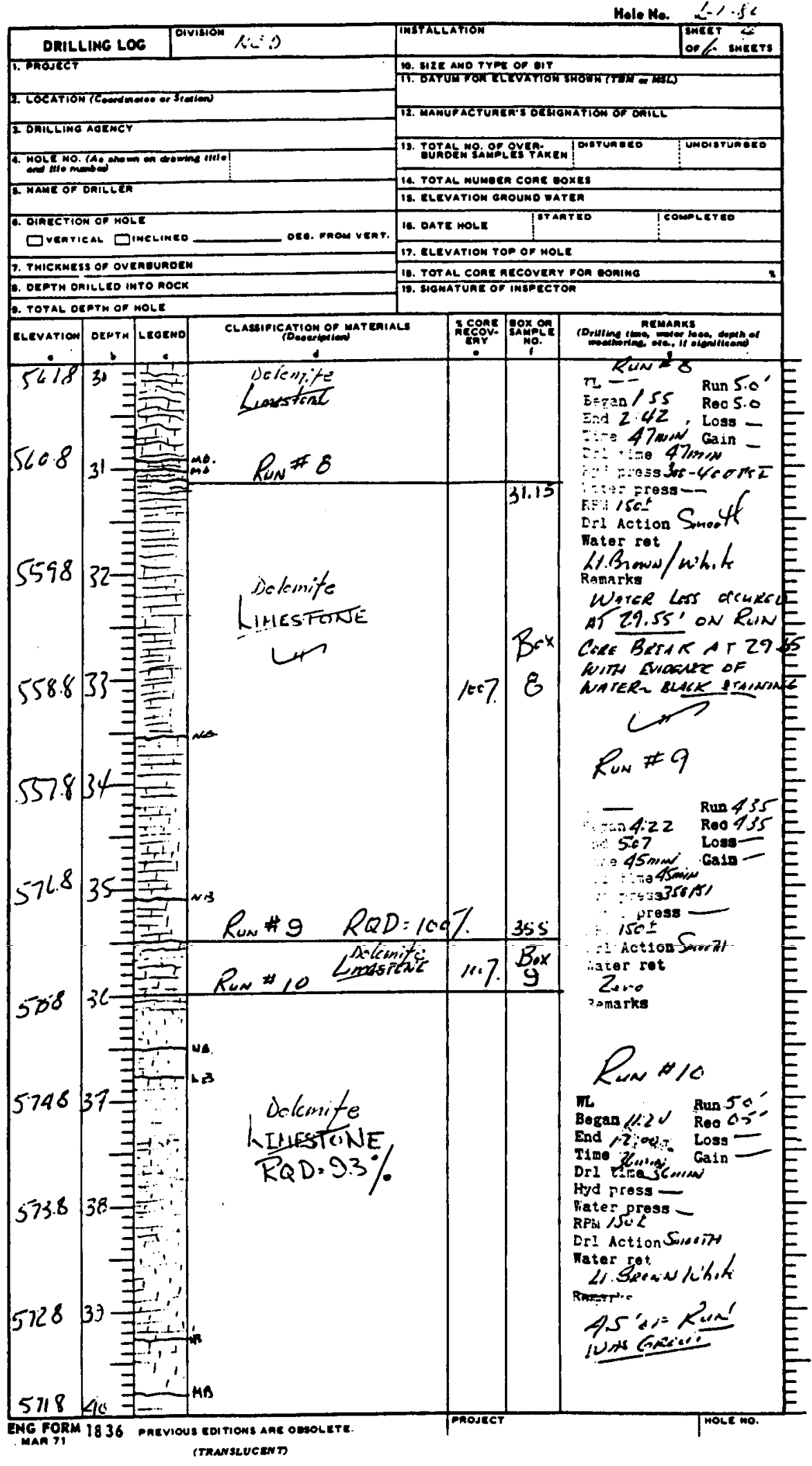


Holo No. $L /: e_{0}^{\circ}$

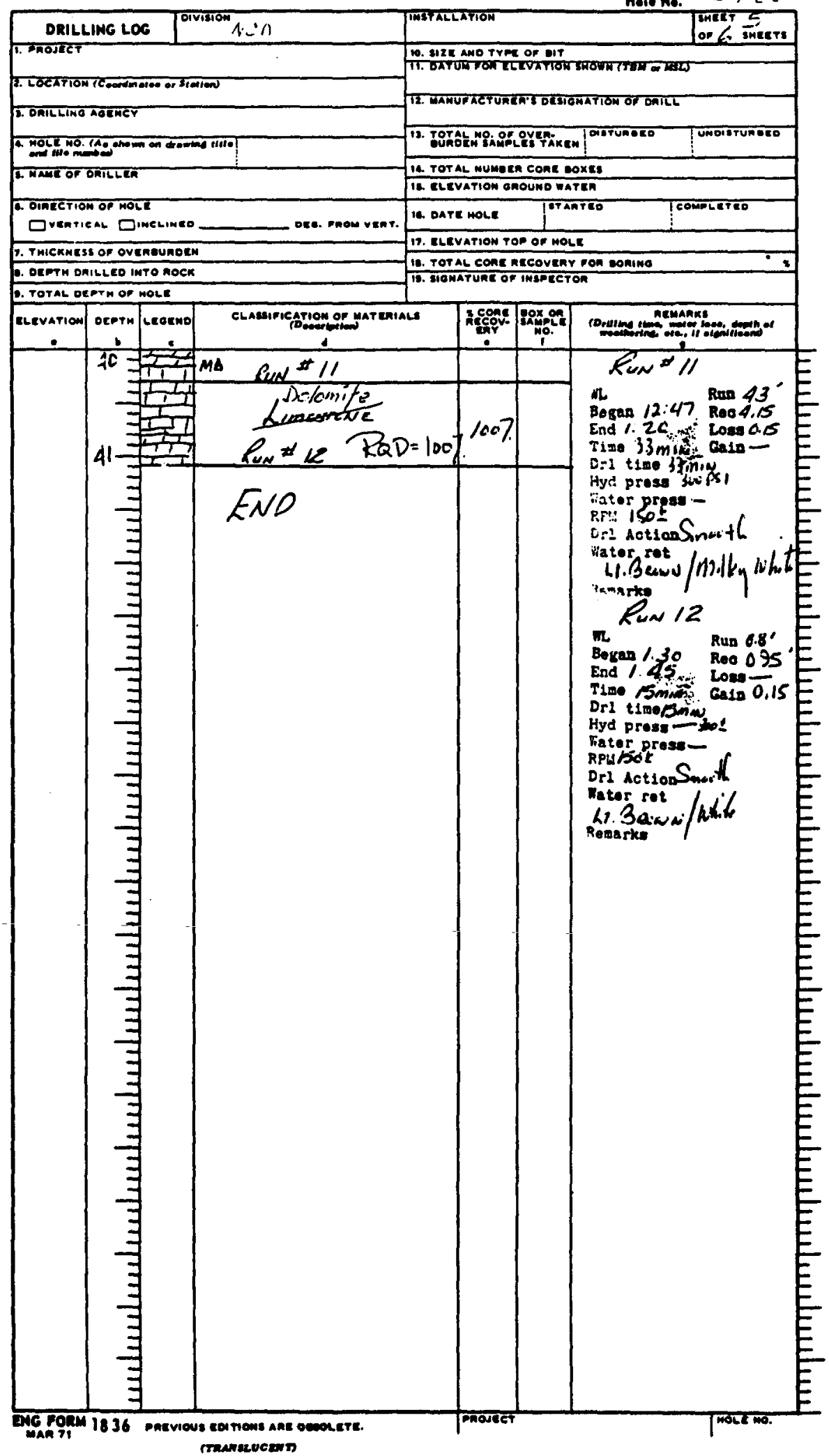


pree 6 of 6

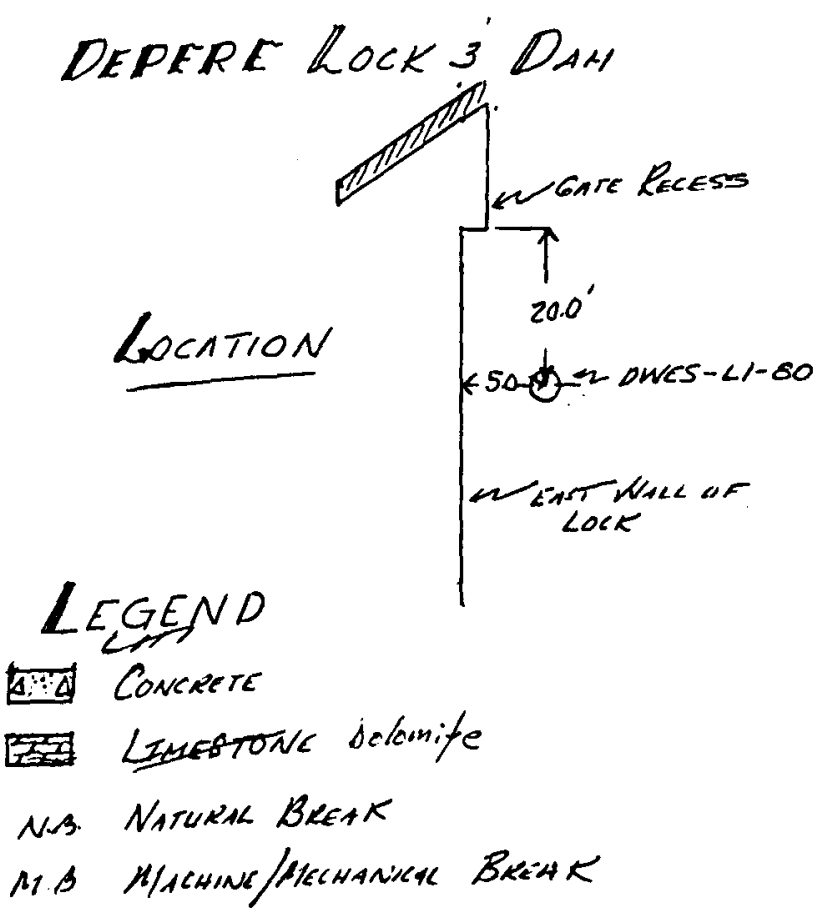


Hole No. D/WES L 2.280

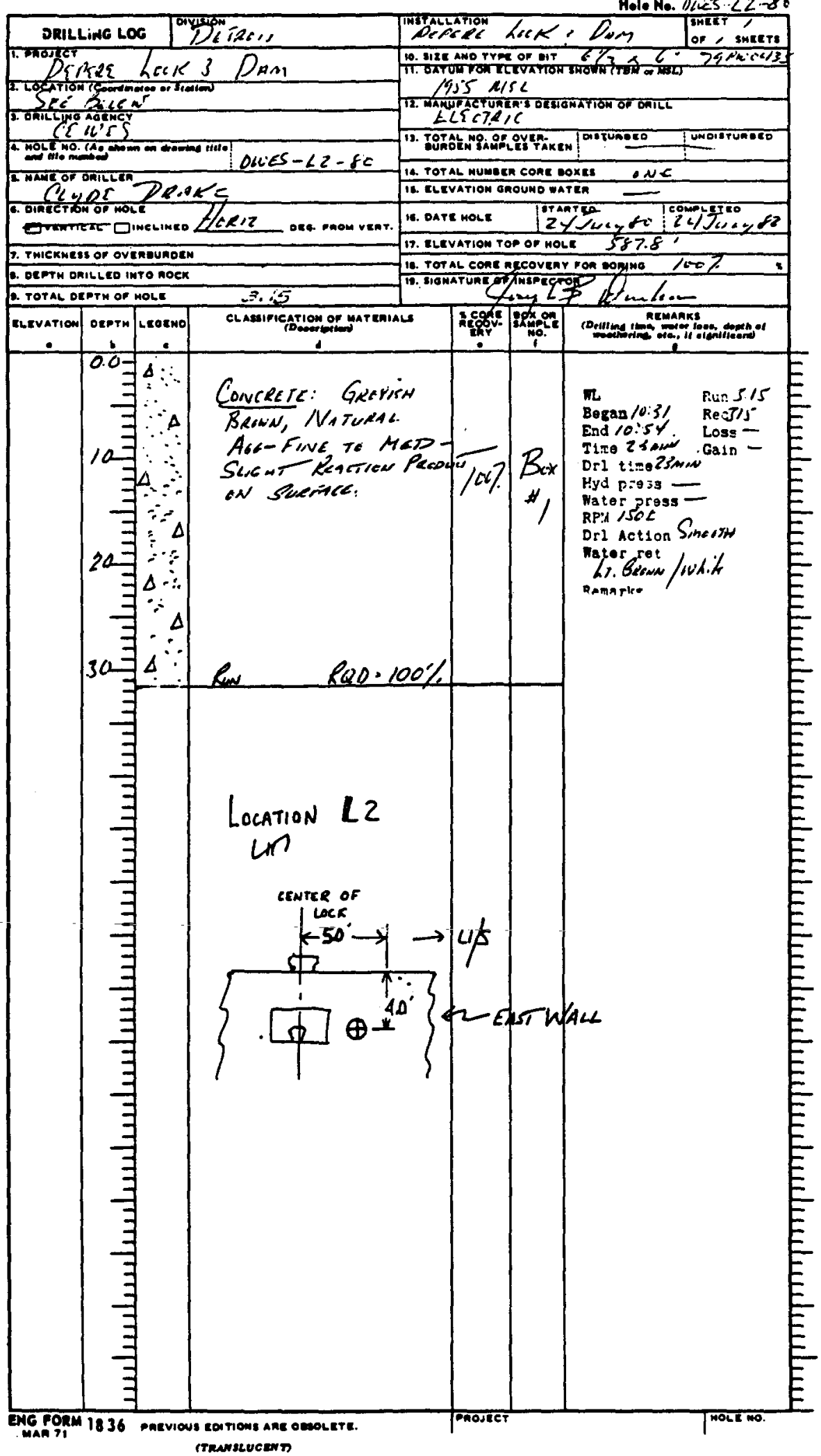


Hole No.D WES E/ -80

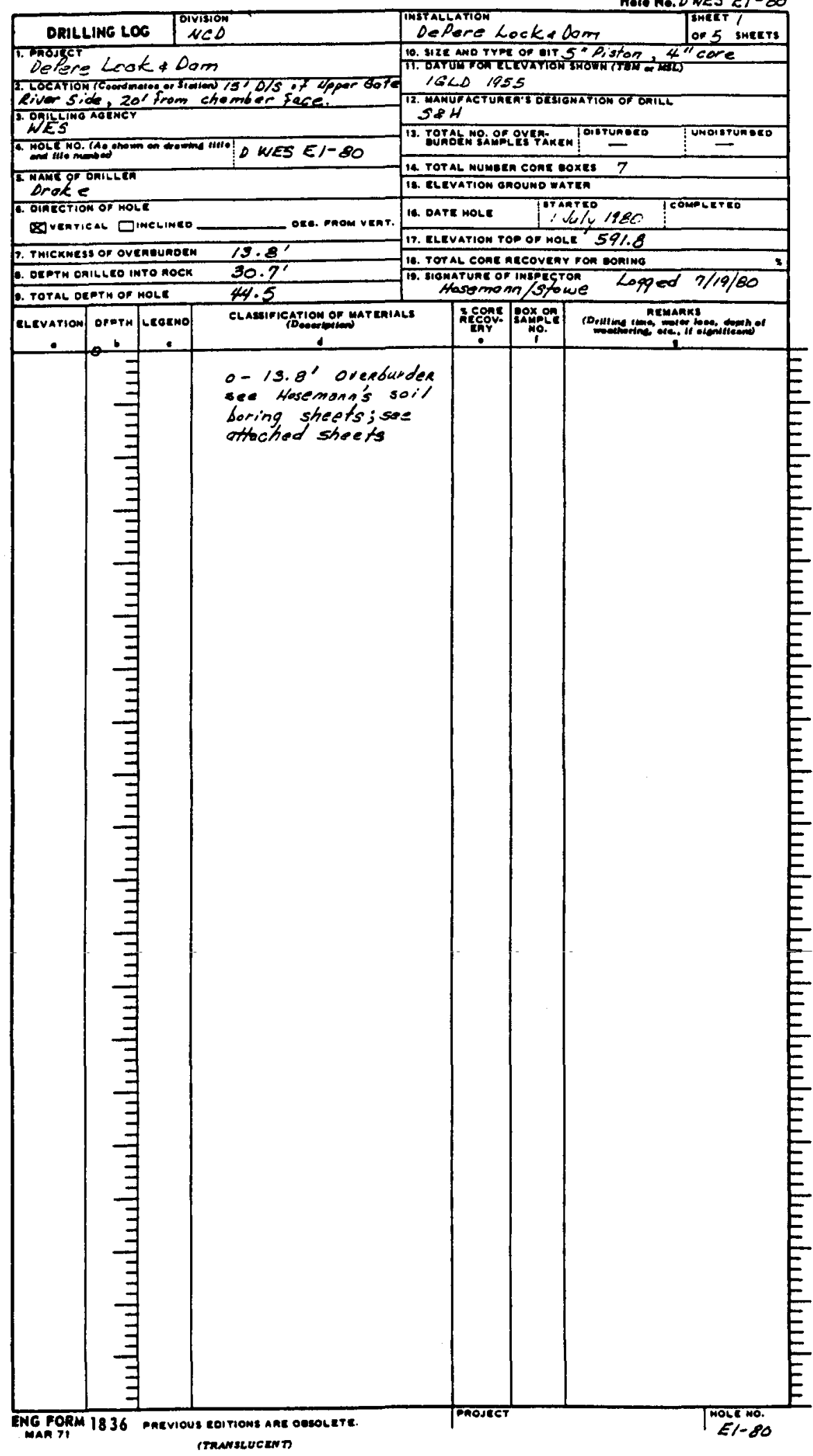


Hole No.

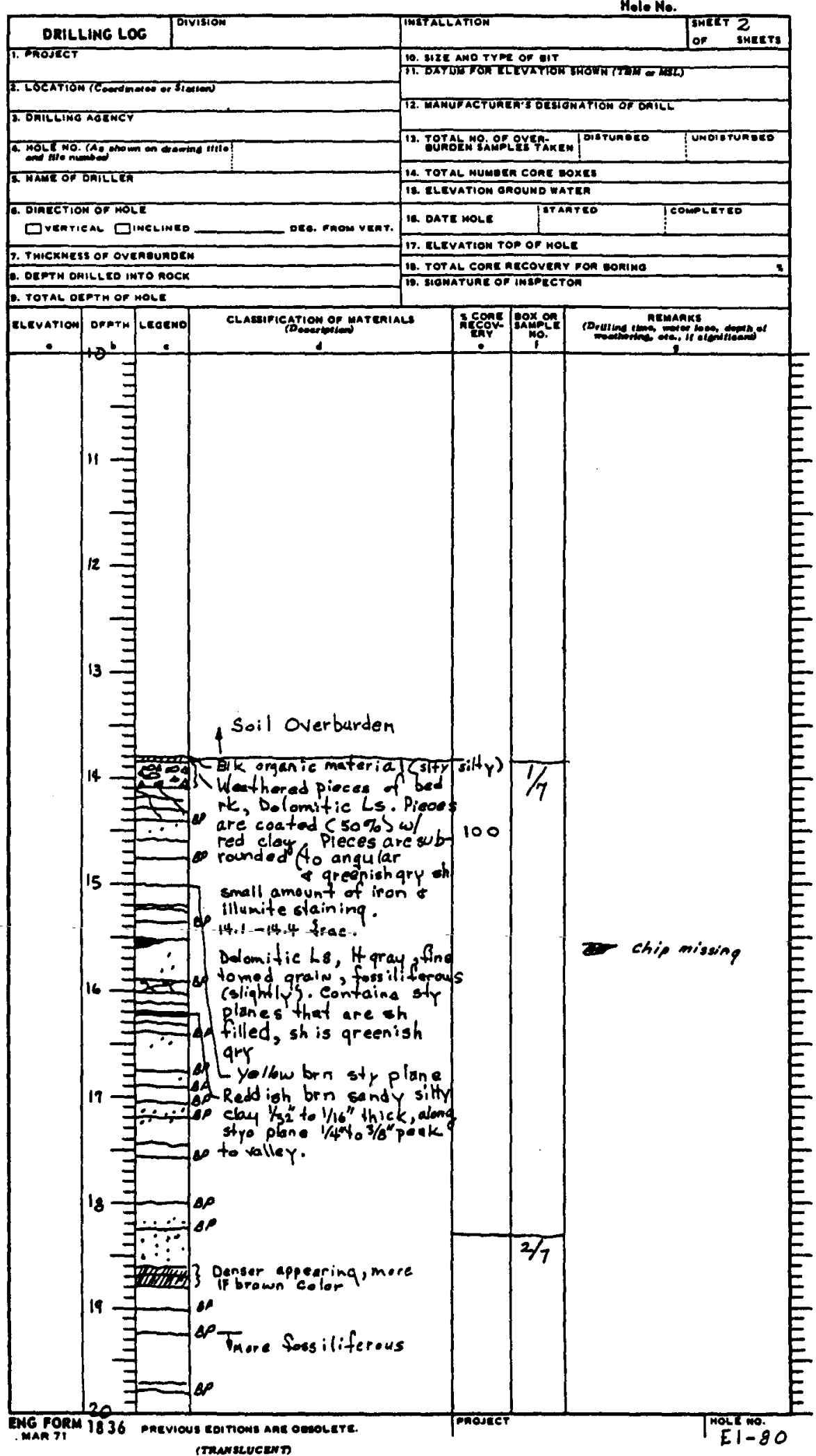


Mole Mo.

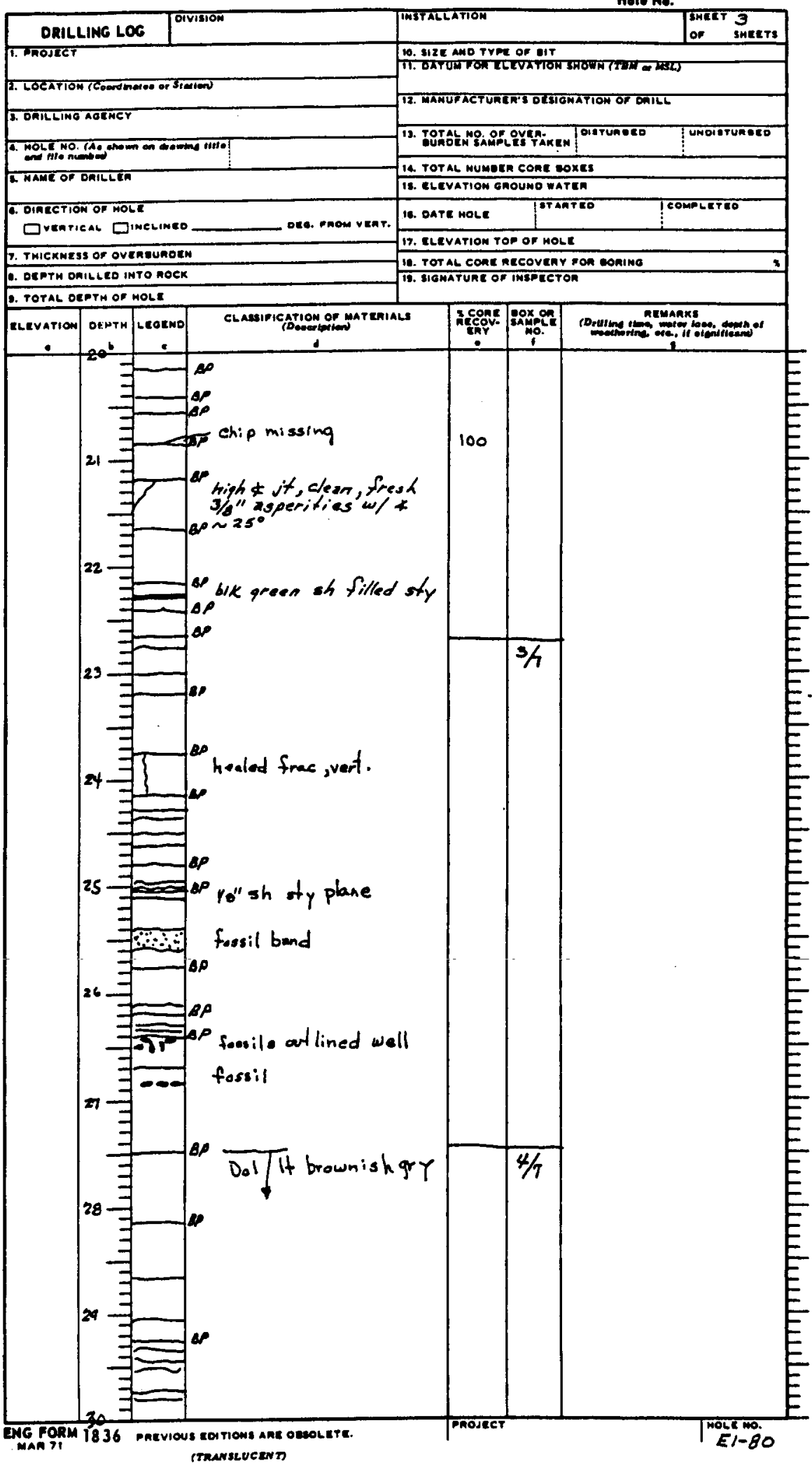




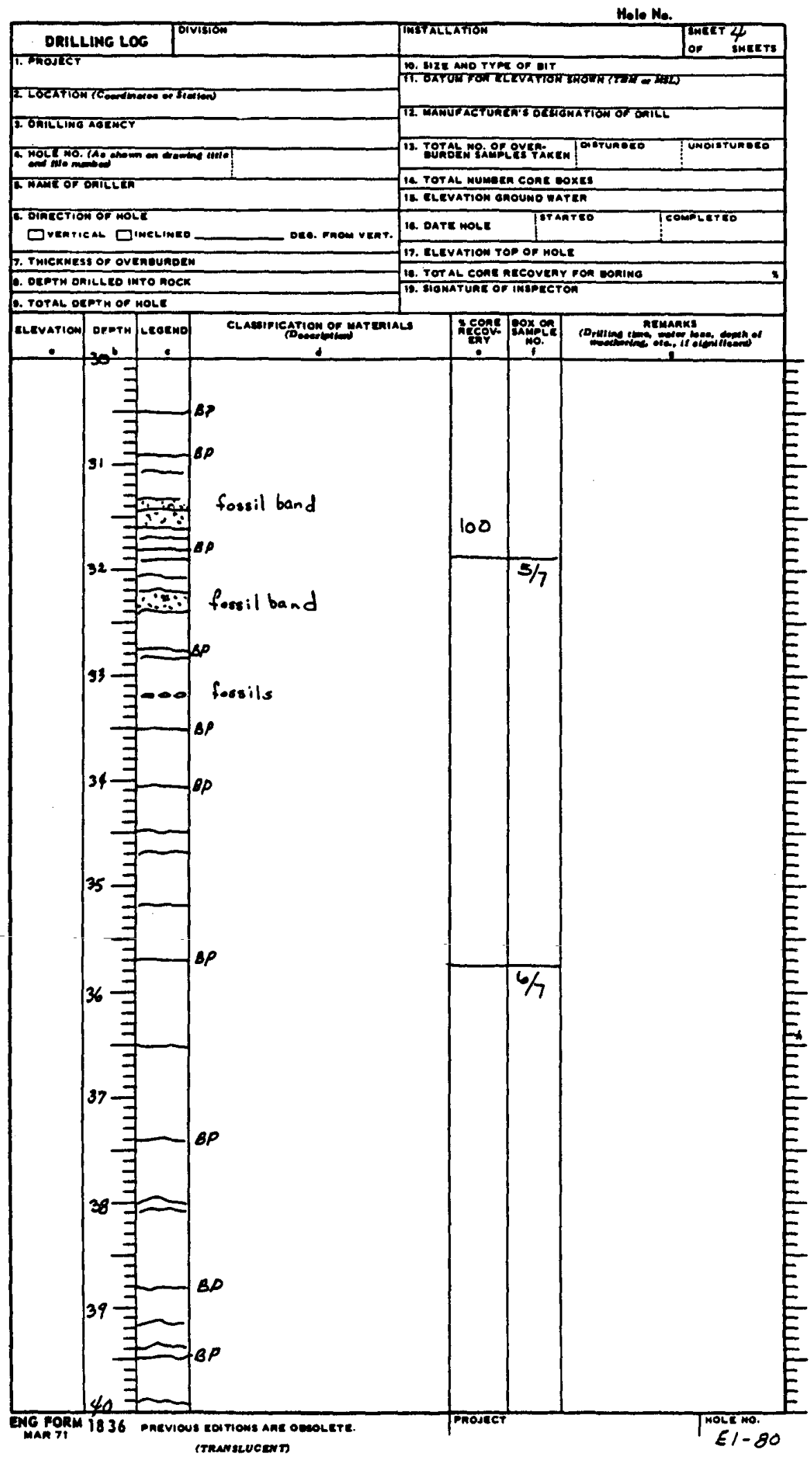




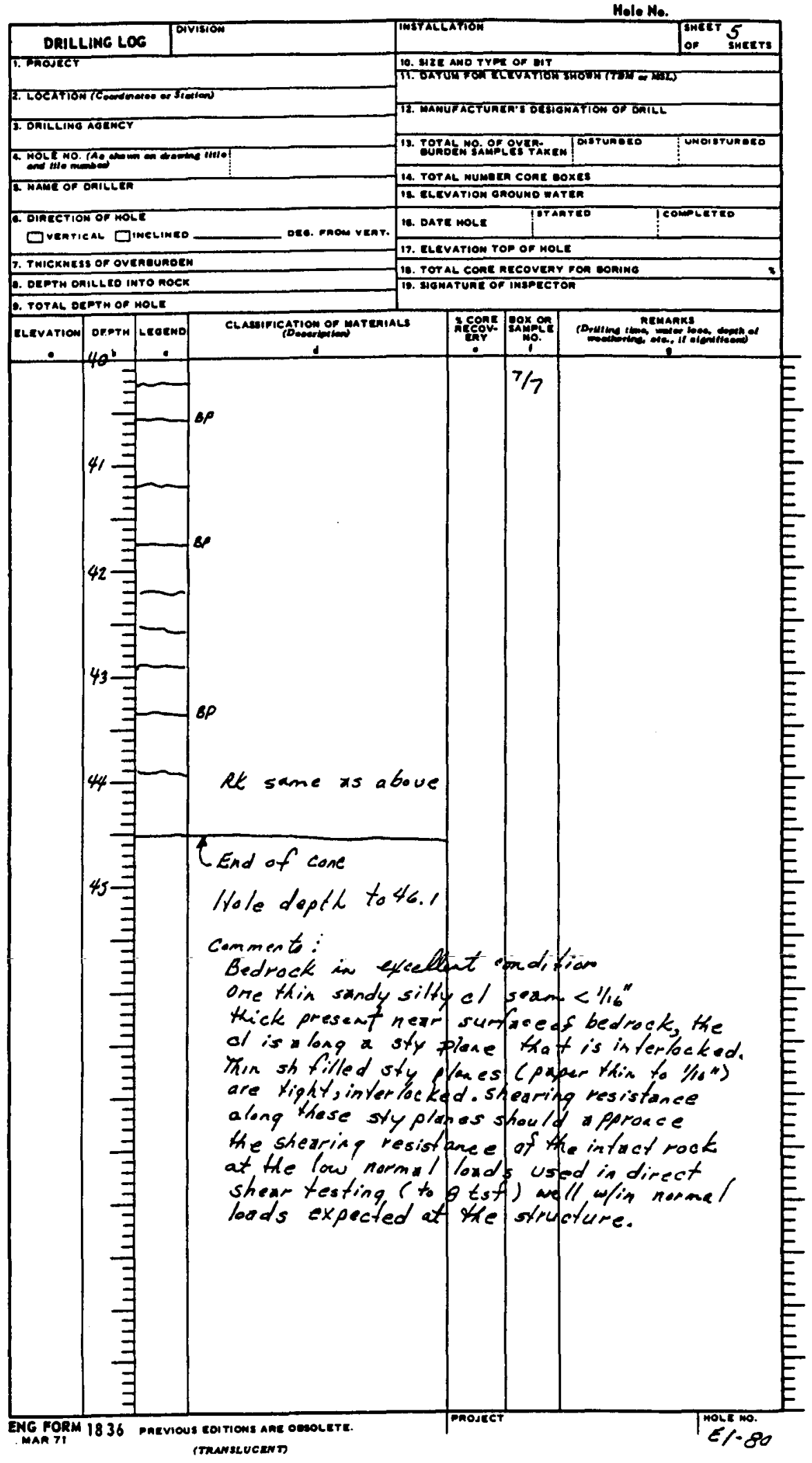




\begin{tabular}{|l|l|l|l|l|l|l|l|l|}
\hline \multicolumn{10}{|c|}{ BORING LOG } \\
FIELD DATA
\end{tabular}

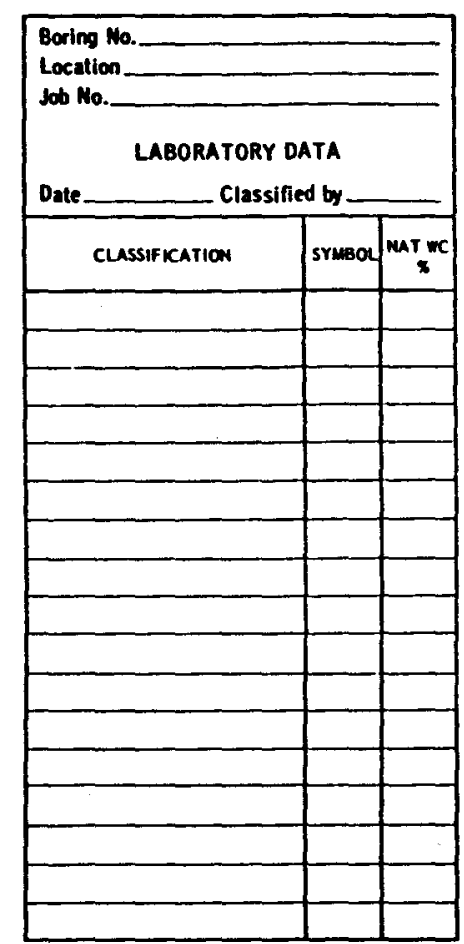

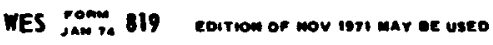

Sheet_Lot if sheets 


\begin{tabular}{|c|c|c|c|c|c|c|c|c|c|c|c|}
\hline \multicolumn{12}{|c|}{$\frac{\text { BORING LOG }}{\text { FIELD DATA }}$} \\
\hline \multicolumn{12}{|c|}{ 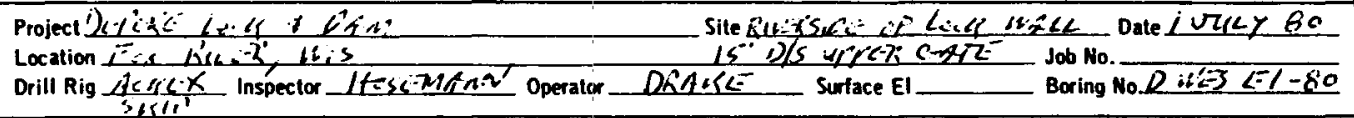 } \\
\hline \multirow{2}{*}{\begin{tabular}{|l|} 
SAMPLE \\
MUMEER \\
Mat
\end{tabular}} & \multirow{2}{*}{ 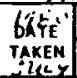 } & \multicolumn{2}{|c|}{ STRATUM } & \multicolumn{2}{|c|}{ DRIVE } & \multicolumn{2}{|c|}{ SAMPLE } & \multirow{2}{*}{$\begin{array}{l}\text { TYPE OF } \\
\text { SAMPLER }\end{array}$} & \multirow[b]{3}{*}{ 72 } & & \multirow{2}{*}{ CLASSIF ICATION AND REMRRKS } \\
\hline & & FROM & To & From & TO & From & To & & & & \\
\hline \multirow[t]{5}{*}{$6 A$} & 1 & & & $5 \frac{1}{2}$ & Drice & $=0$ & geñc & 2. $\Sigma$ & & \multirow{2}{*}{\multicolumn{2}{|c|}{ 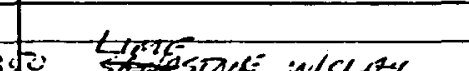 }} \\
\hline & & & & 7.5 & 7.7 & 7.5 & 7.7 & st,ckloy & Zise: & 8 & \\
\hline & & & & & & & & & & & B.dexx - Coray-Brown \\
\hline & & & & 77 & s.c & & $3 \frac{1}{2}$ & $\int 0 \times 1+2=0+4$ & 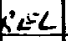 & & NoT KLecilexeD \\
\hline & & & & & & & & & & & List intati at T.7 \\
\hline 7 & & & & $8, c$ & 10.0 & E.1 & 8,2 & $4 x^{-1} i$ es & $E \in$ Cid. & Kaget & 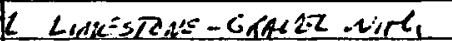 \\
\hline \multirow[t]{5}{*}{22} & & & & & & & & & & & \multirow{2}{*}{ 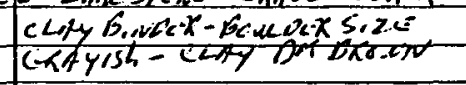 } \\
\hline & & & & & & & & & & & \\
\hline & & & & 10.6 & \multirow[t]{2}{*}{412.6} & & & \multirow{2}{*}{$4 " x-5=i c$} & 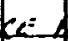 & \multirow{2}{*}{ aras } & 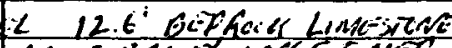 \\
\hline & & & & & & & & & & & 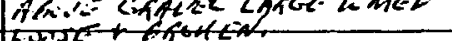 \\
\hline & & & & & & & & & & & \\
\hline & & & & & & & & & & & \\
\hline \multirow[t]{5}{*}{$i$} & & & & 12.6 & 15.4 & 12.6 & $13 . E$ & .1 & & & 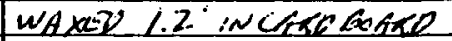 \\
\hline & & & & & & & & & & & 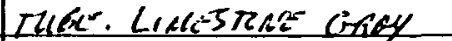 \\
\hline & & & & & & & & & & & 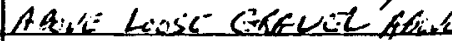 \\
\hline & & & & & & & & & & & \\
\hline & & & & & & & & & & & \\
\hline
\end{tabular}

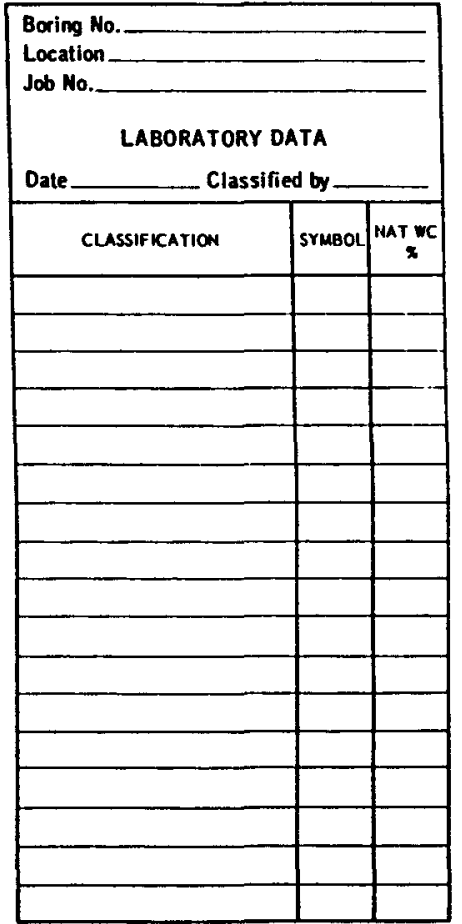

WES Samp 819 Eourion or wov ign way ae useo

Sheet_2 of 4 sheets 


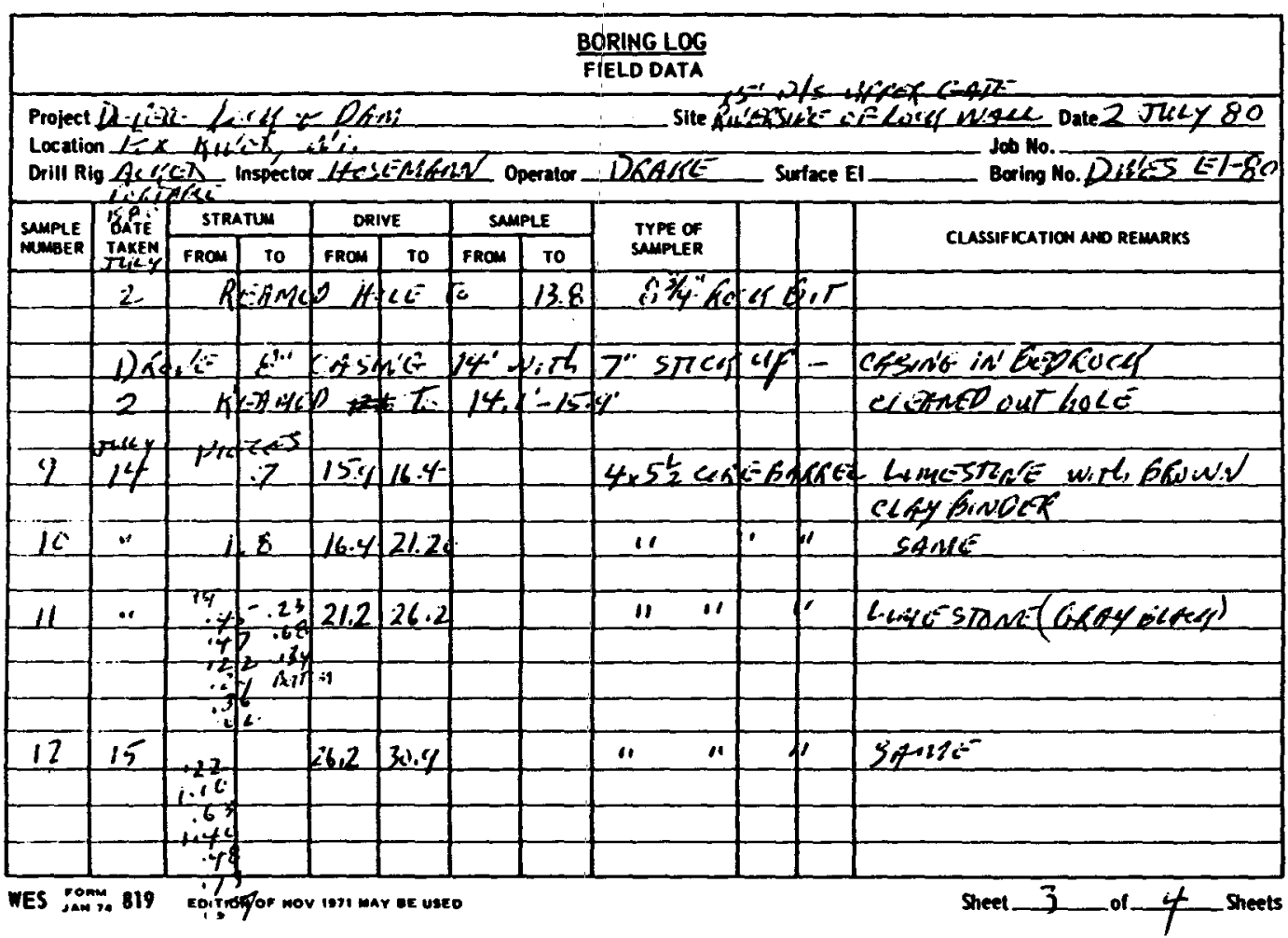

Boring Mo.

Location

Job No.

LABORATORY DATA

Date

Classified by

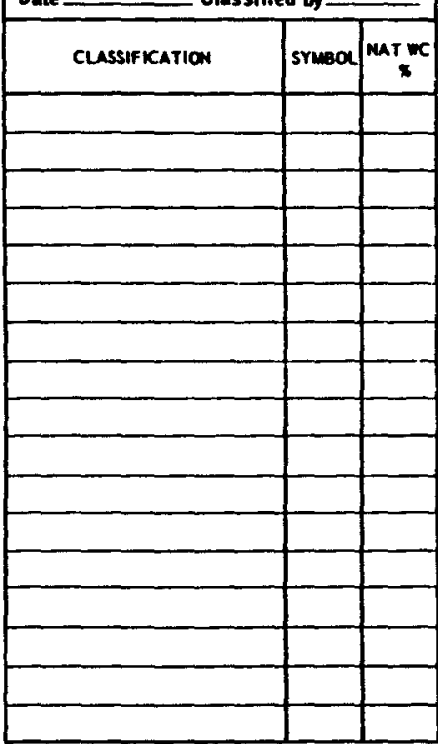



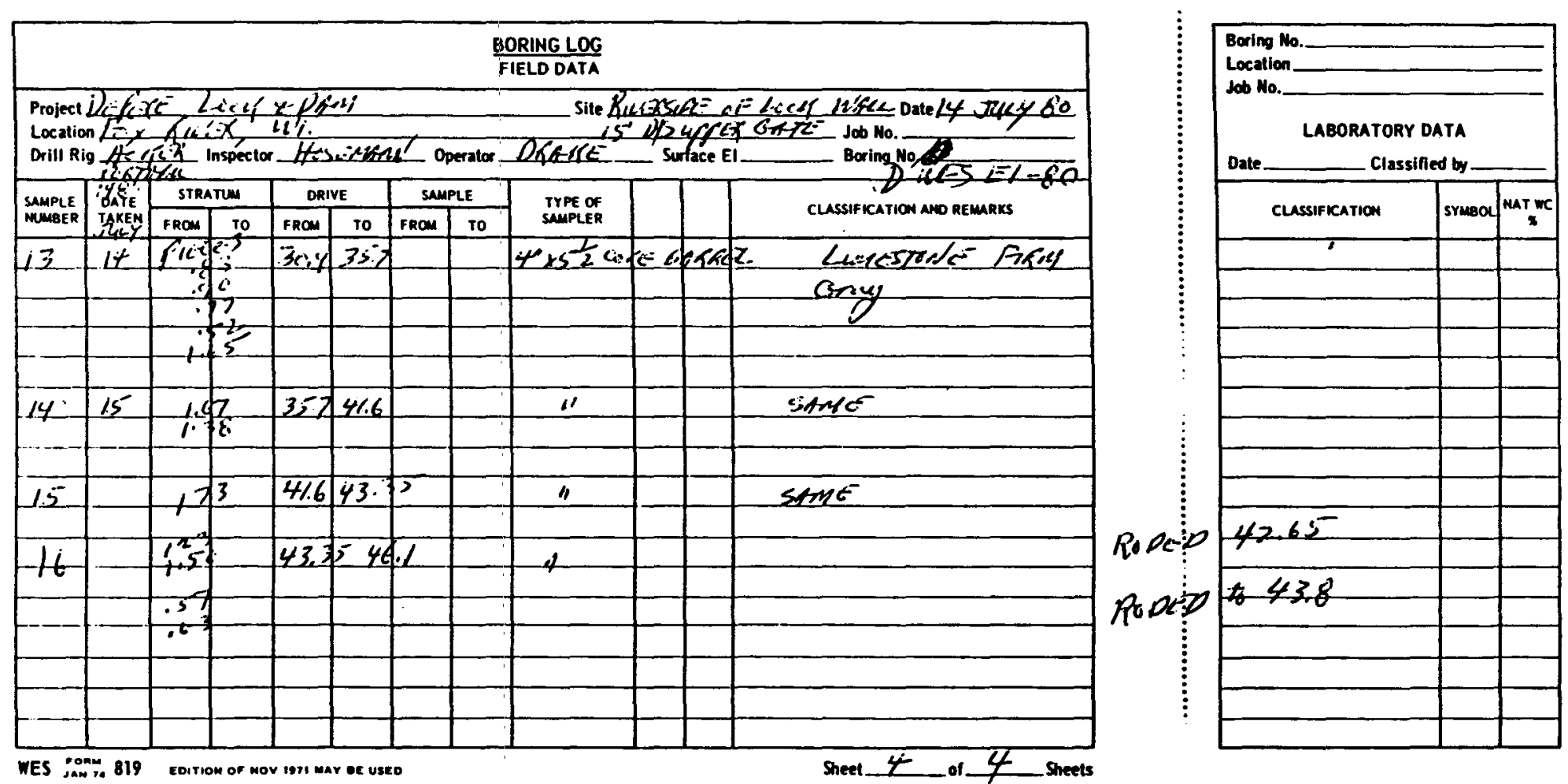

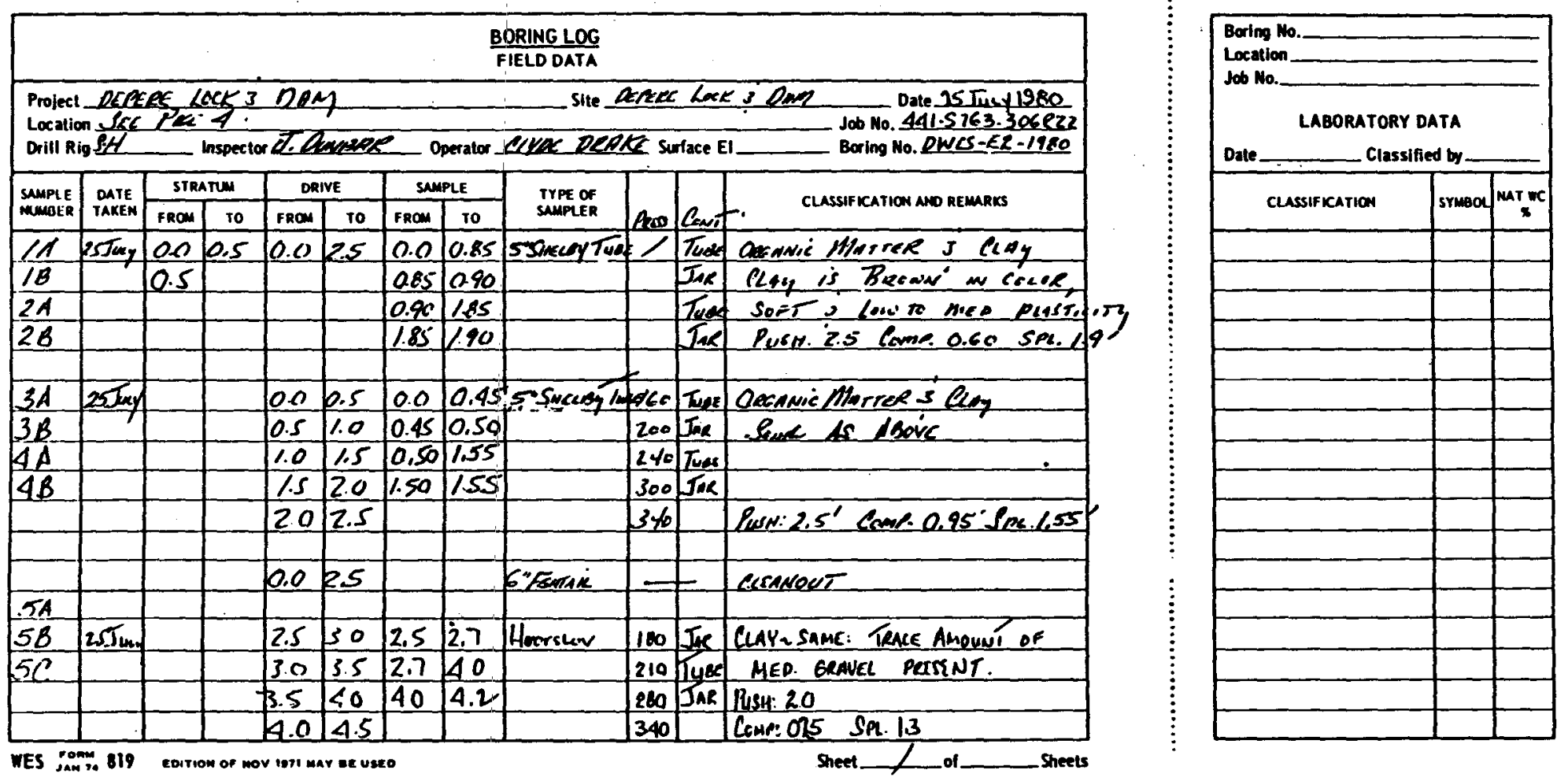


\begin{tabular}{|c|c|c|c|c|c|c|c|c|c|c|c|}
\hline \multicolumn{12}{|c|}{$\frac{\text { BORING LOG }}{\text { FIELD DATA }}$} \\
\hline \multicolumn{12}{|r|}{ Date $26 \sqrt{\mathrm{me}} / \mathrm{SO}_{0}$} \\
\hline \multicolumn{12}{|c|}{ 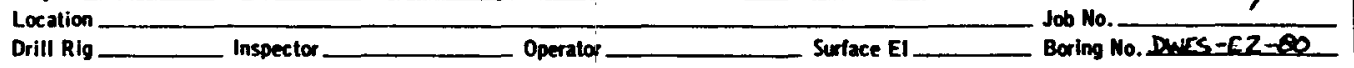 } \\
\hline \multirow{2}{*}{$\begin{array}{c}\text { SMMPLE } \\
\text { MMMBER } \\
\end{array}$} & \multirow{2}{*}{\begin{tabular}{l|l} 
DATE \\
TAKEM
\end{tabular}} & \multicolumn{2}{|c|}{ STRATMU } & \multicolumn{2}{|c|}{ DRIVE } & \multicolumn{2}{|c|}{ SAMPLE } & \multirow{2}{*}{$\begin{array}{c}\text { TYPF OF } \\
\text { SAMPLER }\end{array}$} & & & \multirow{2}{*}{ CLASSIF KCATION ANO REMRRSS } \\
\hline & & Frou & To & From & TO & From & To & & & & \\
\hline & & & & 2.5 & 4.5 & $\Longrightarrow$ & $=$ & 6"Fourain & . & $=$ & CleAnout \\
\hline & & & & & & & & & & & \\
\hline \multirow[t]{3}{*}{$\epsilon$} & $25 T_{12}$ & & & 4.5 & 485 & 4.5 & 485 & Aroescon & 420 & Jar & Gravely CNYY - Ampuee stopr \\
\hline & & & & & & & & & & & ON Boulder \\
\hline & & & & & & & & & & & \\
\hline $7 A$ & stues & & & 485 & 69 & 4.85 & 6.90 & $4 k \times 4 C=B I$ & - & Tuen & Geaneuy CuAY i lms Bomper \\
\hline \multirow{10}{*}{$7 B$} & & & & & & 4.85 & 6.90 & & & Jue & Rec. 2 preces of las - one \\
\hline & & & & & & & & & & & of cole. \\
\hline & 25stuen & & & 6.9 & 122 & 6.9 & 122 & $4 Y_{2} \times 4^{\prime} B L$ & 二 & $B_{\text {ox }}$ & Gaveuy Cany \\
\hline & $26 \sqrt{m}$ & & & 12.2 & 15.1 & 14.15 & 1510 & $4 K^{\prime \prime} \times 4^{\prime} \mathrm{Bb}$ & 工 & B.x & Geaveluy Clay 3 LMs. Boulpe \\
\hline & & & & & & & & & & & Rec. $0.65^{\prime}$ of lins from Boul \\
\hline & & & & & & & & & & & Quncate Stacis at $14.15^{\prime}$ i \\
\hline & & & & & & & & & & & Rre $0.95^{\prime}-G_{e a r}$ Beous, Nkt \\
\hline & & & & & & & & & & & Blacro Orf. \\
\hline & $26 \mathrm{Tund}$ & & & 5.1 & 155 & $=$ & E & $A K \times A^{A} B \mathbb{B}$ & & $\mathrm{Bux}$ & 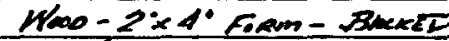 \\
\hline & & & & & & & & & & & eff / Cancerte Becow Woop. \\
\hline & & & & & & & & & & & \\
\hline
\end{tabular}

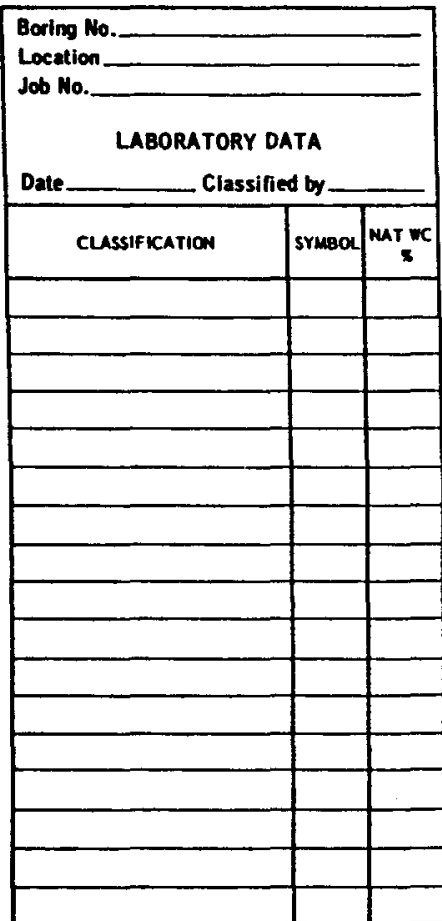



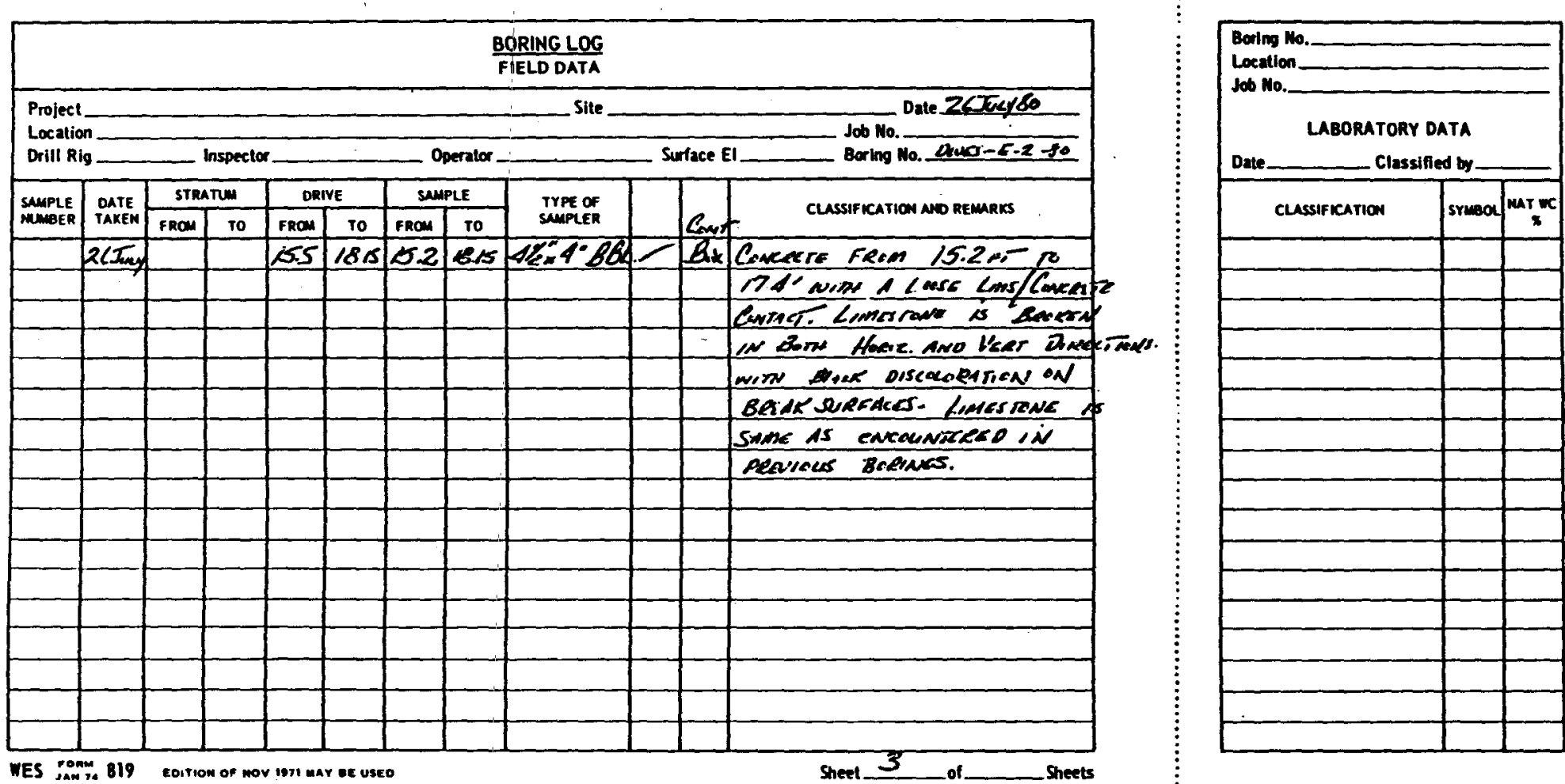
Hole Ho. axidi-EZds

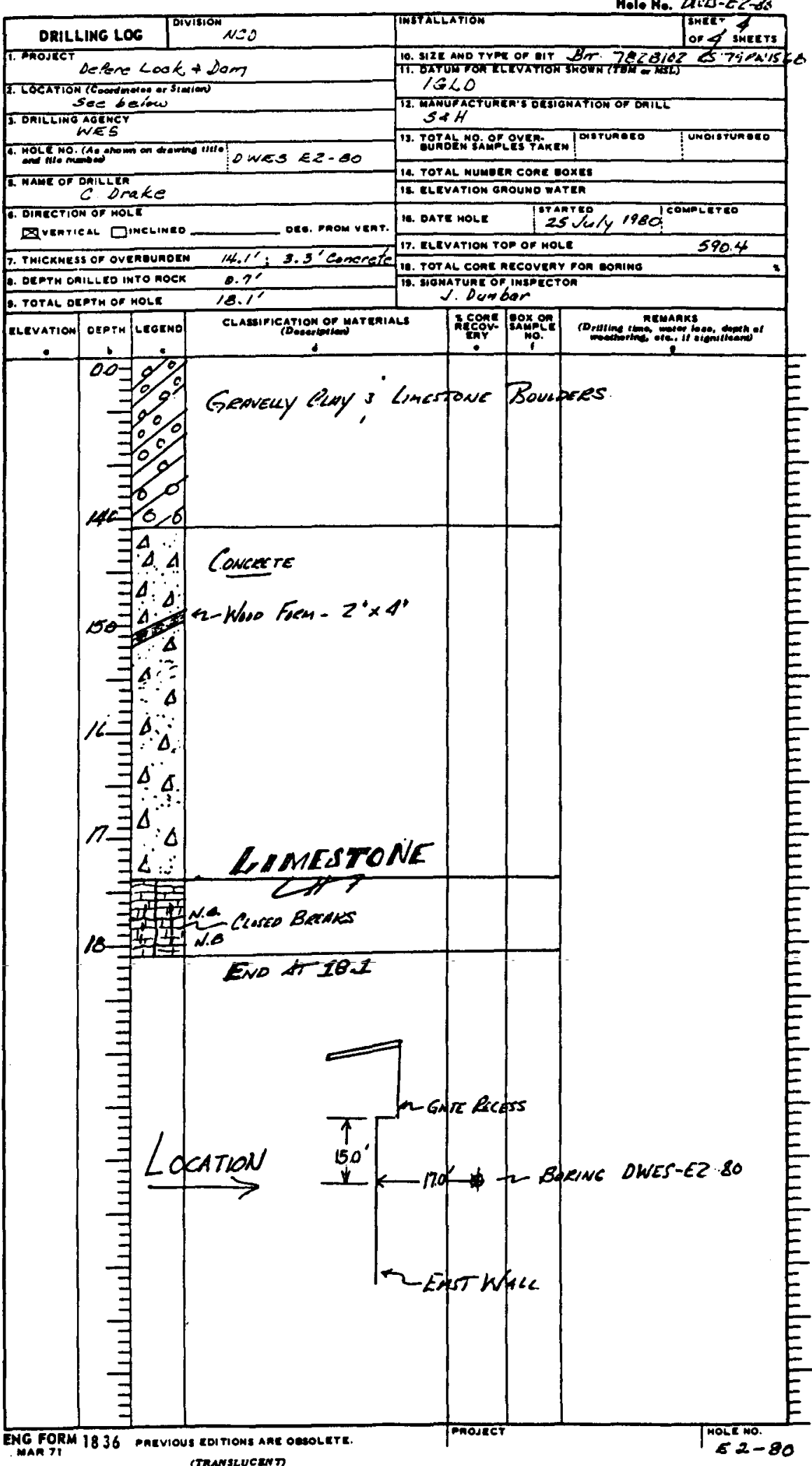


Hele Ne. 0 WES DI-80

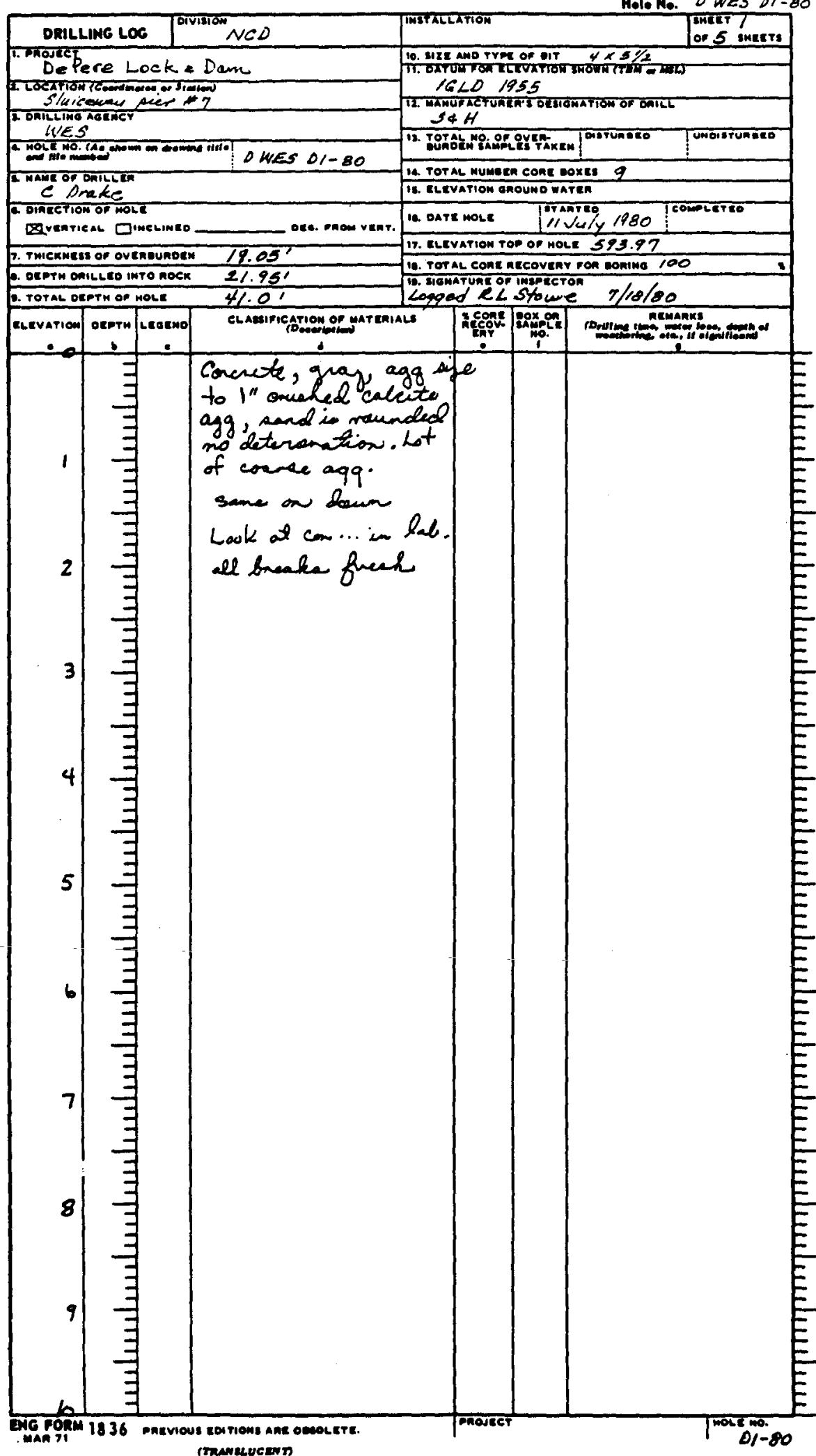


Holo No.

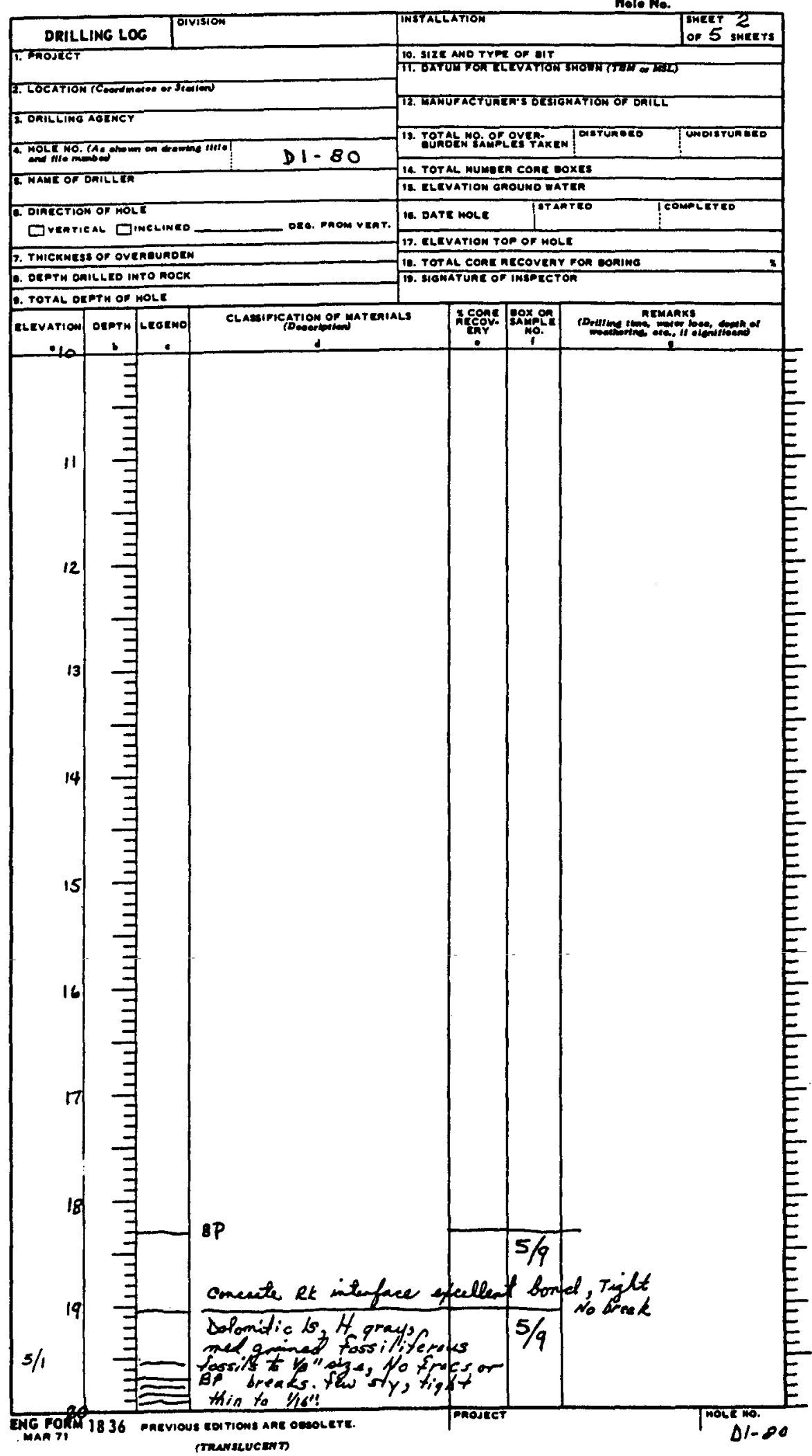




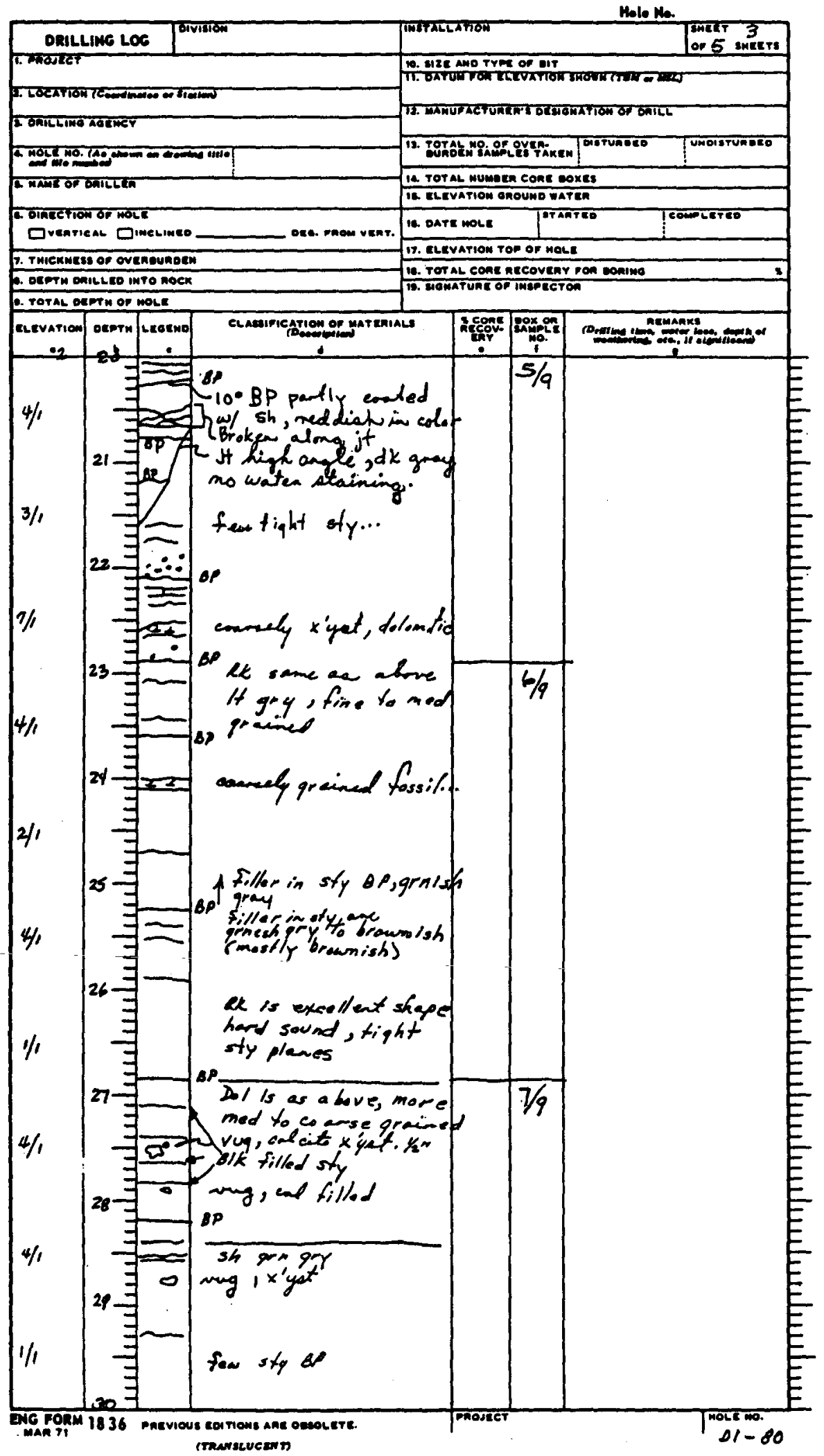


Hele $N$.

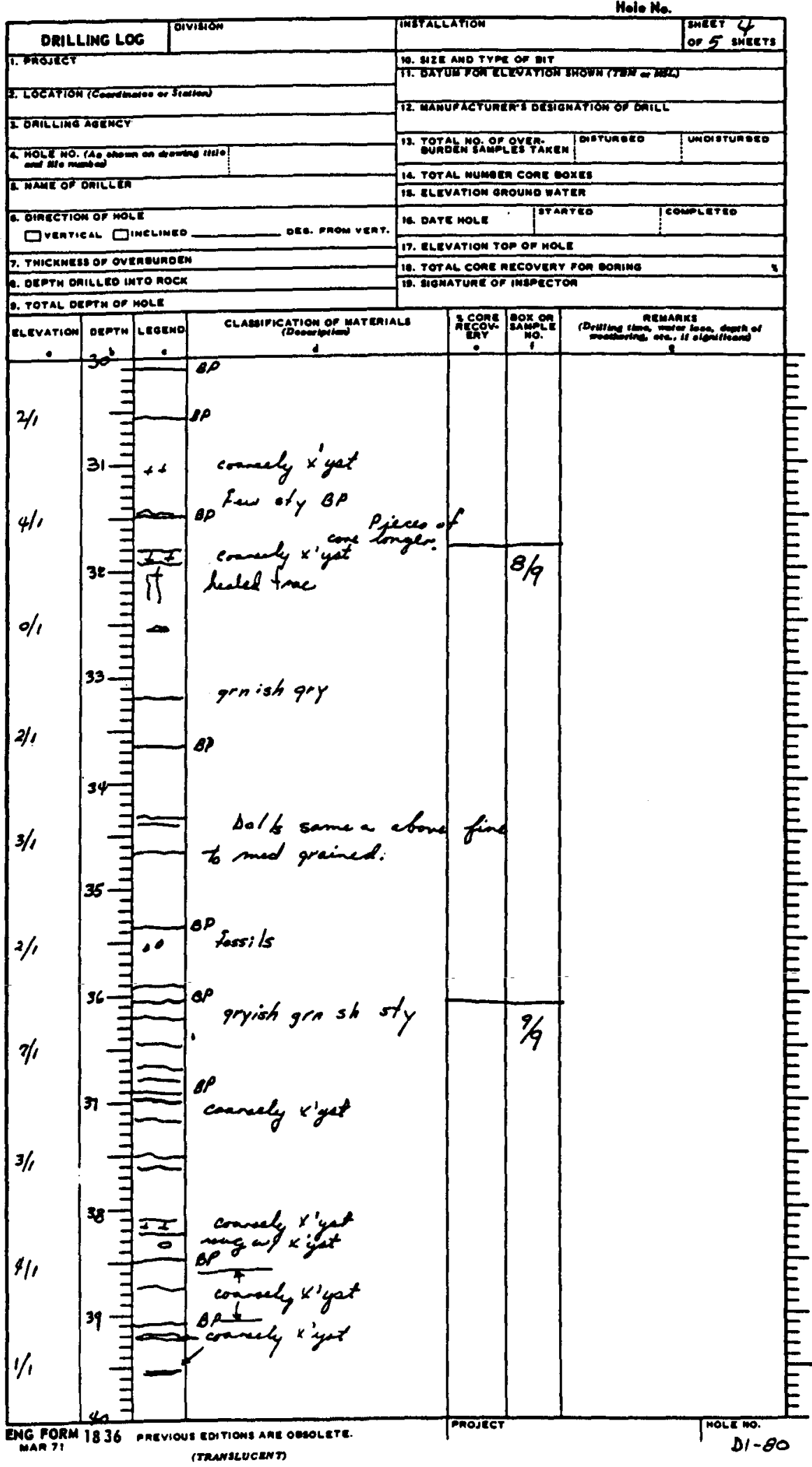




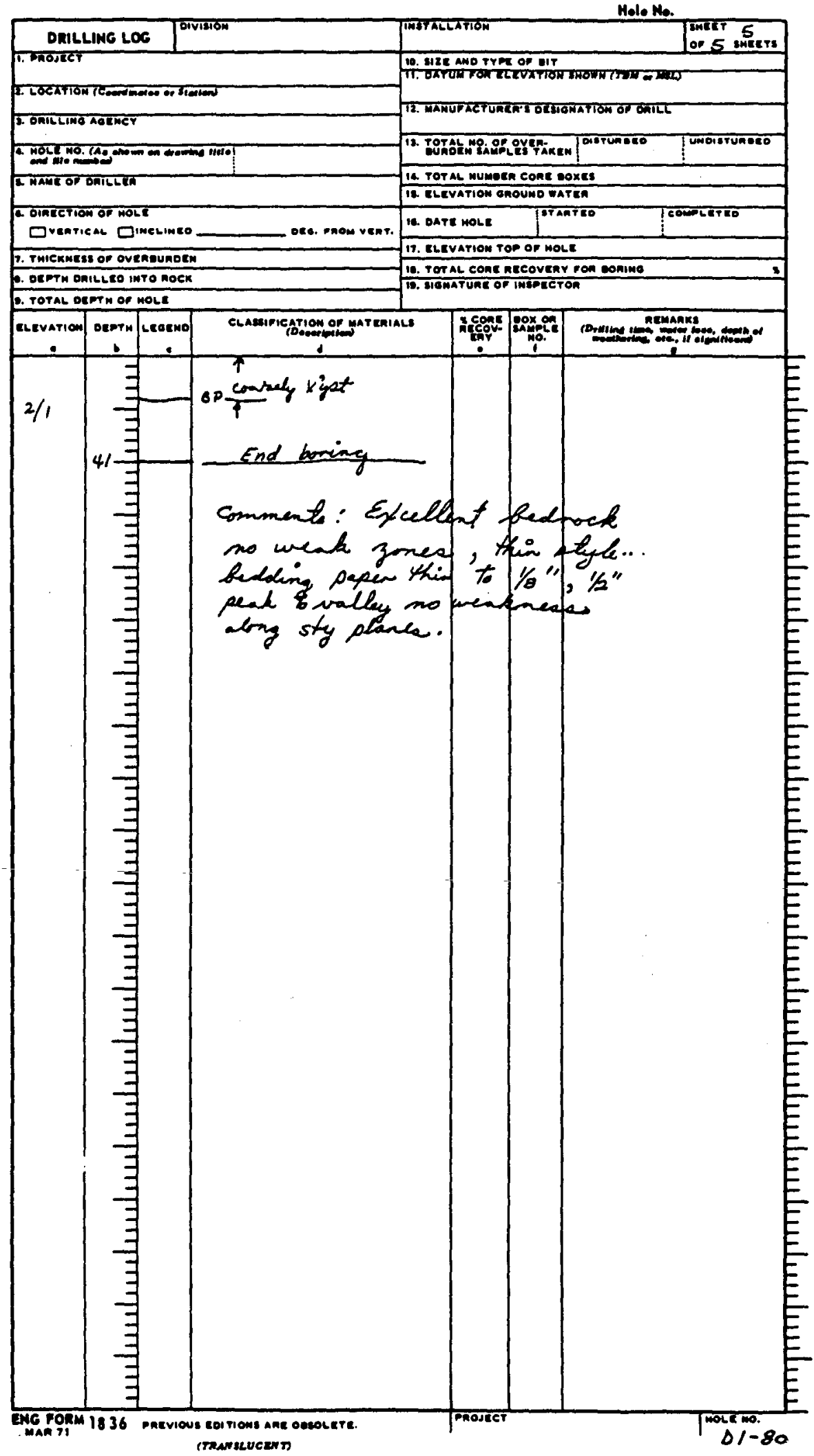


Holo No. 0 WES DZ-80

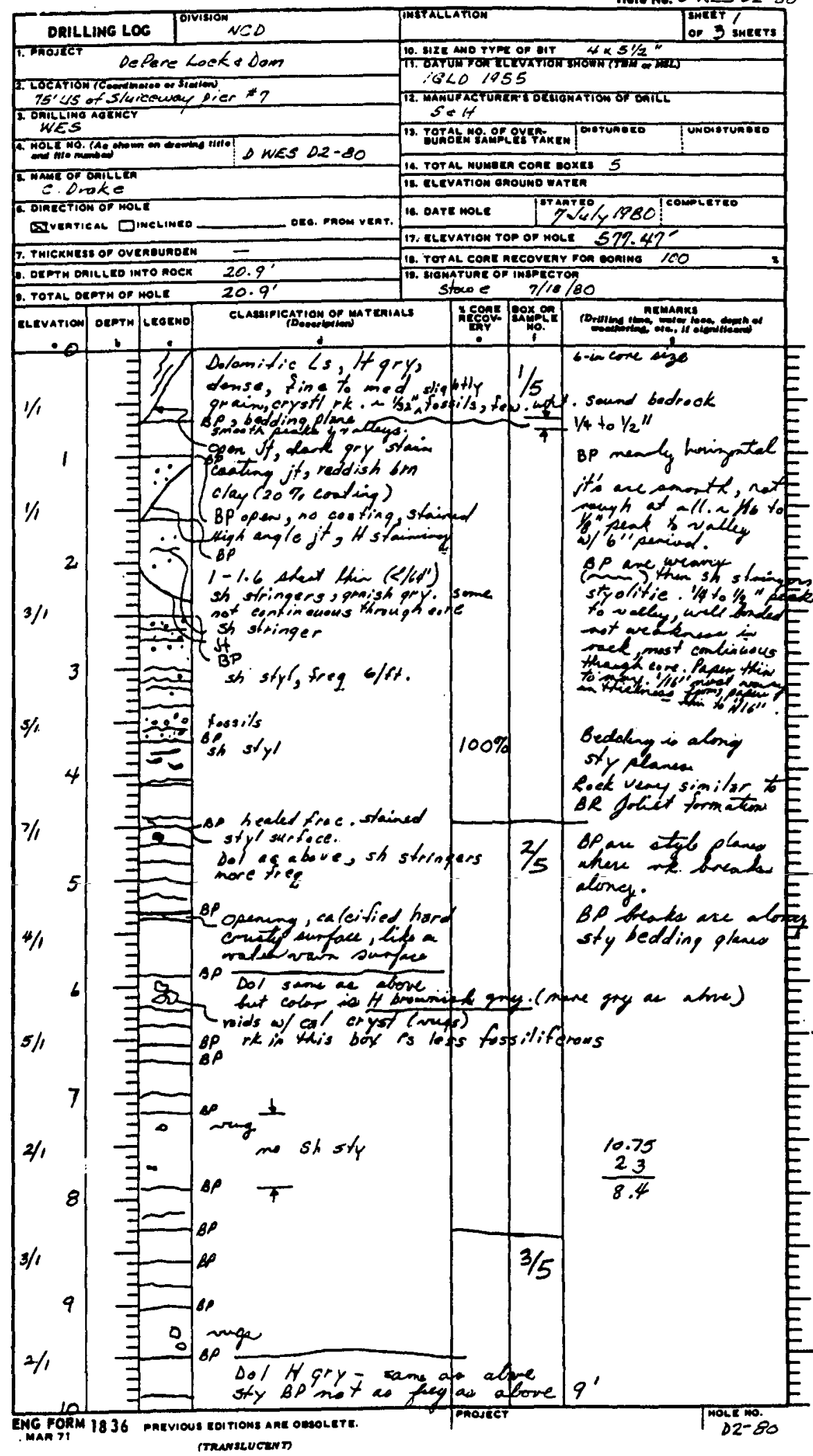




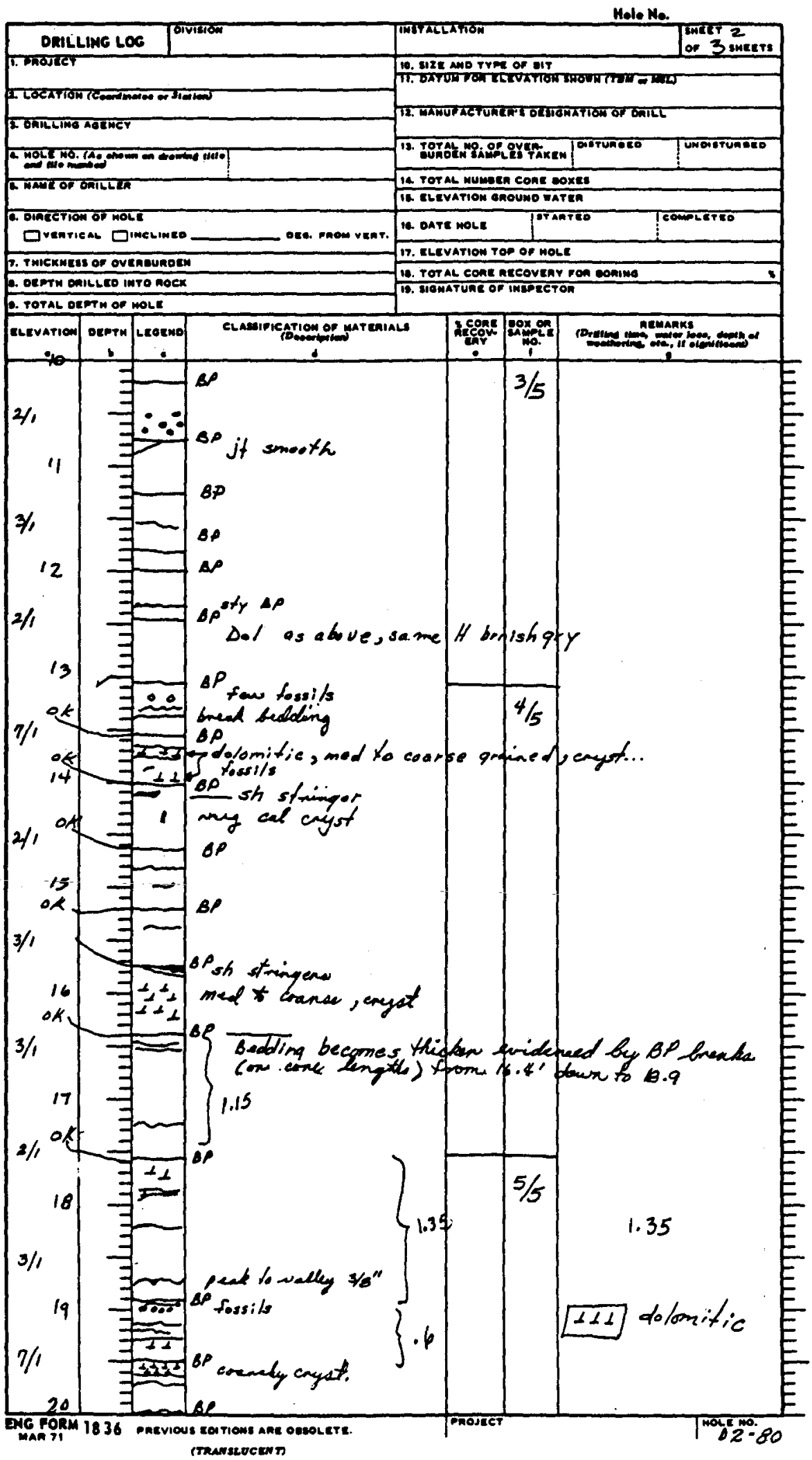


Hele No.

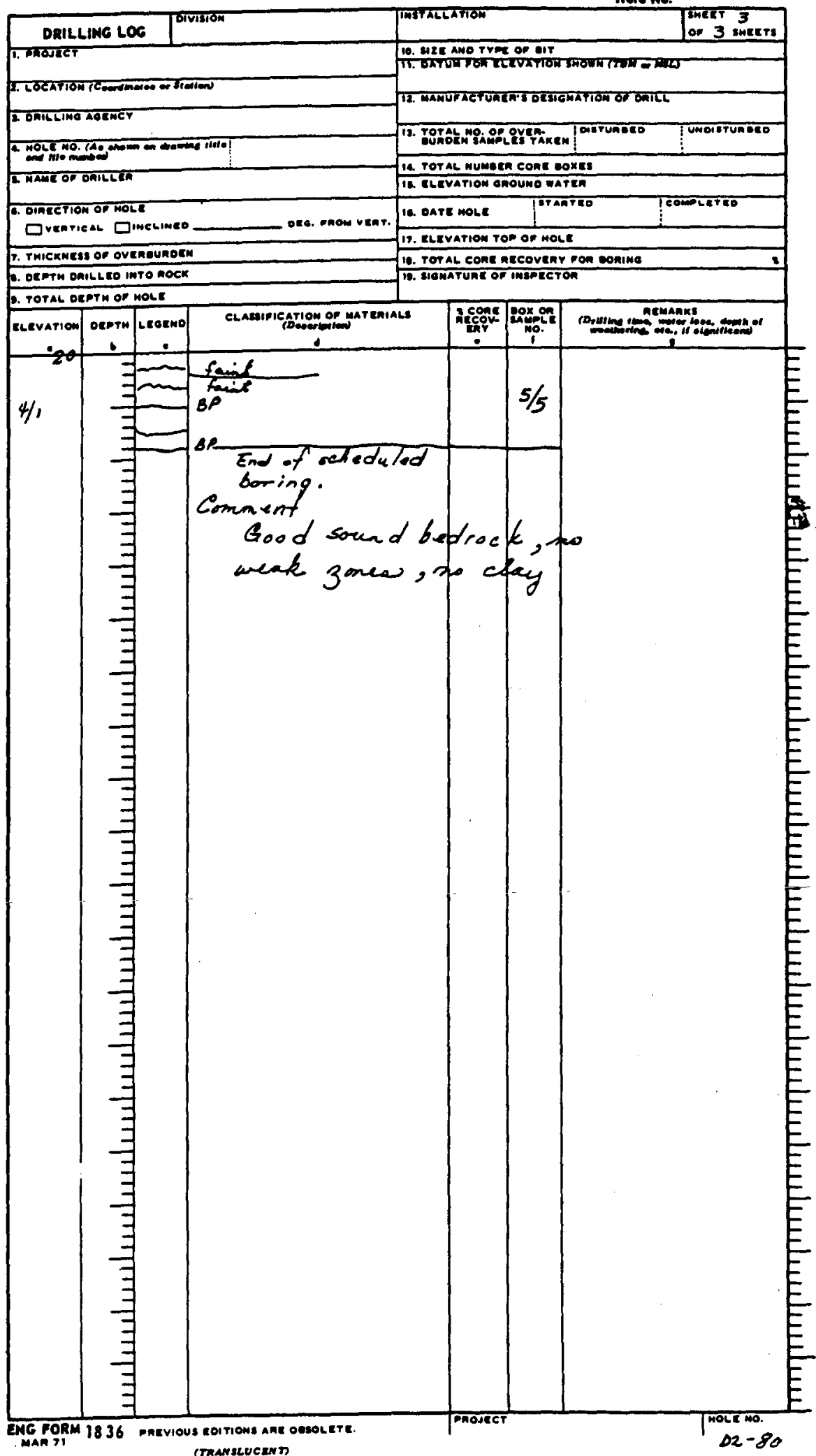


Hele No. 0 wes D: 80

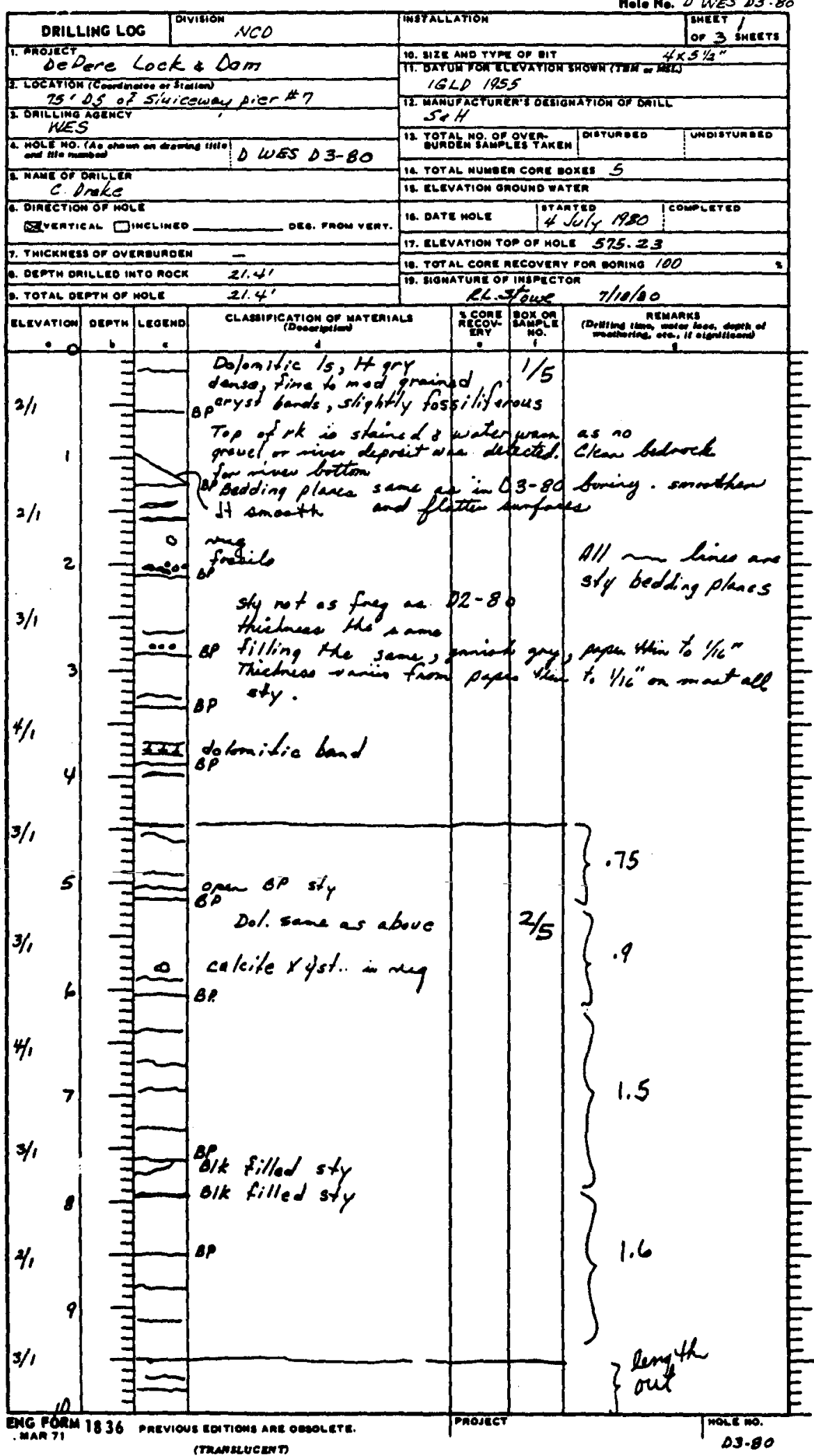


Hole Ne.

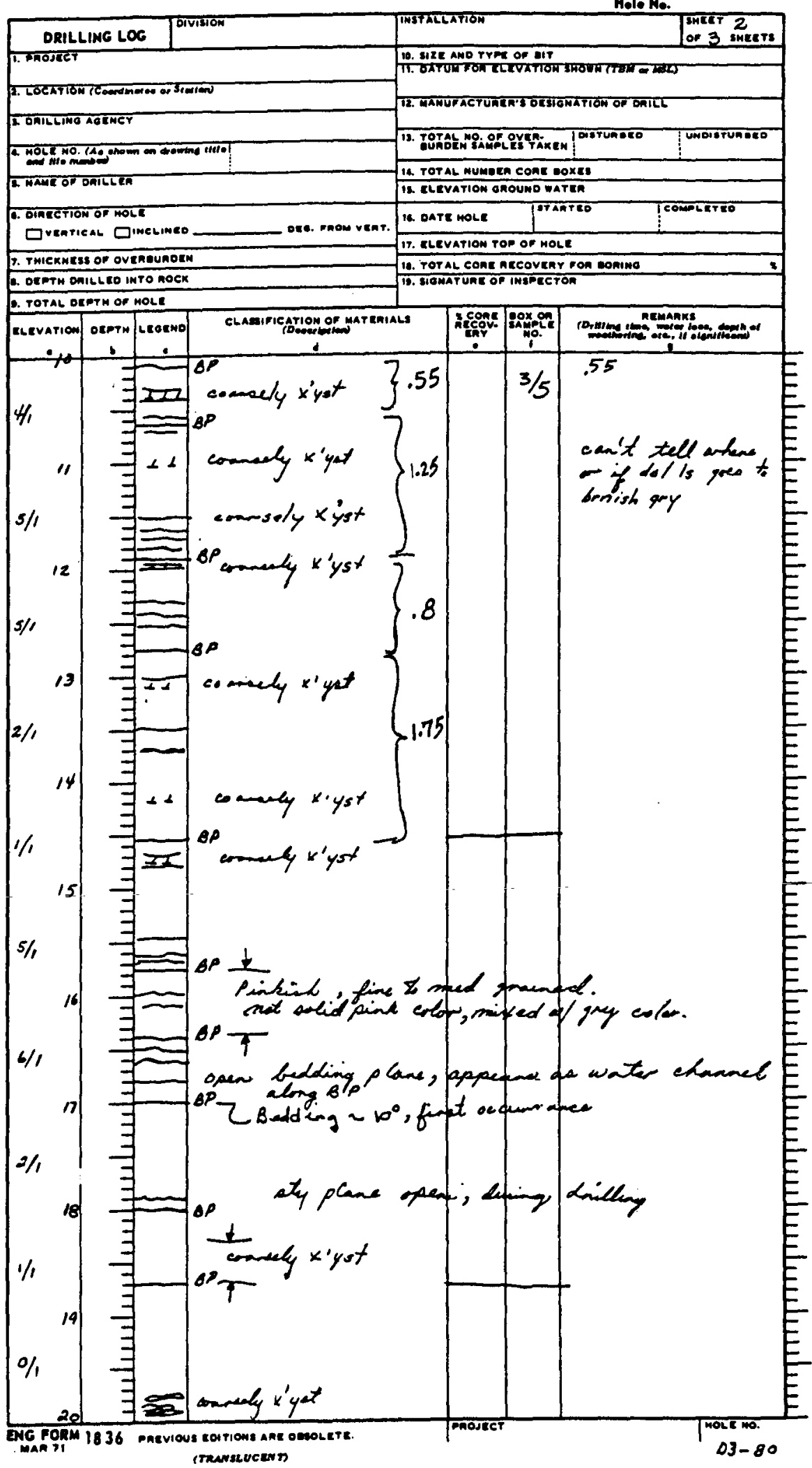




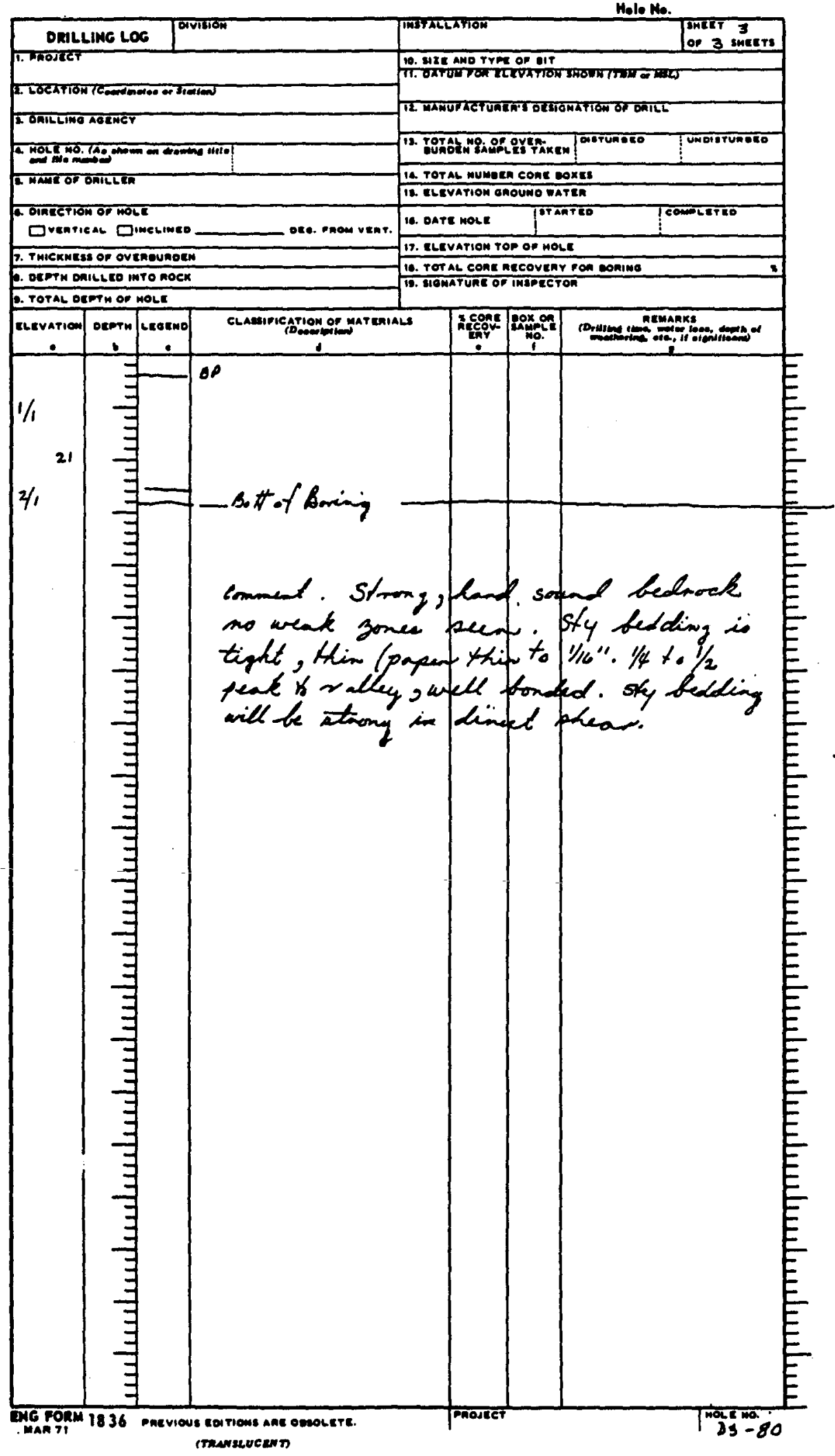



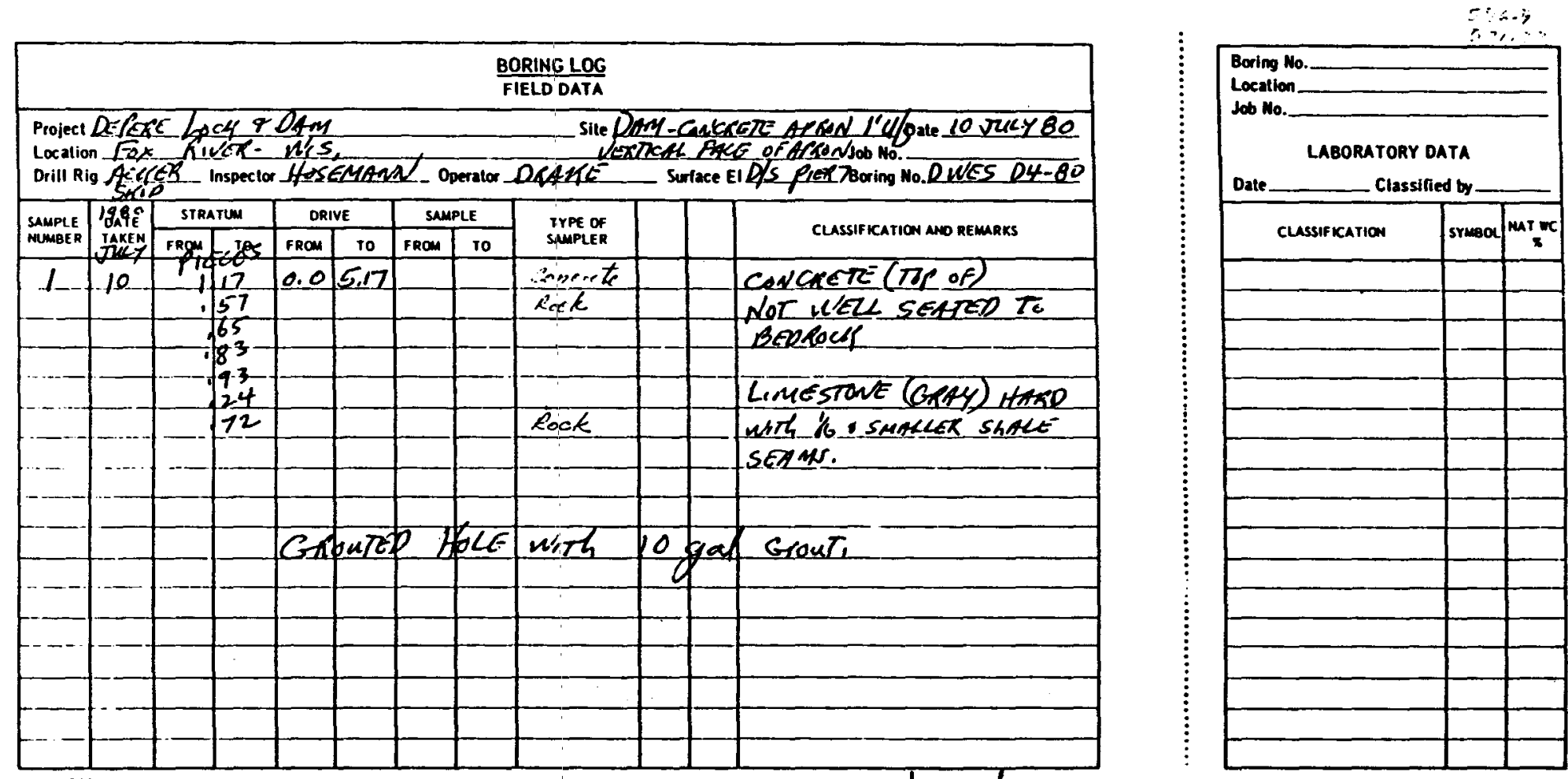

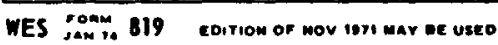

Sheel I of I sheets 

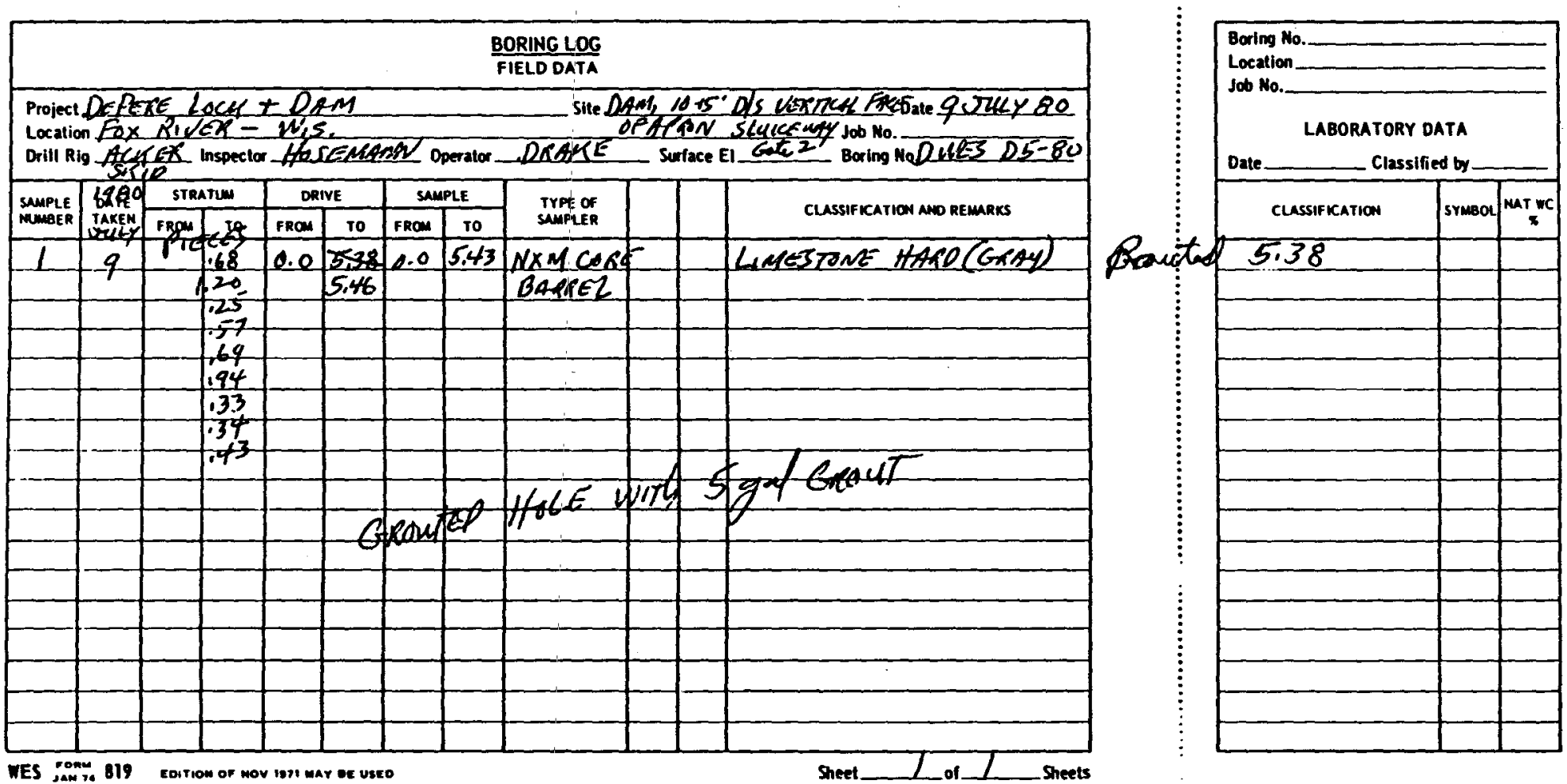


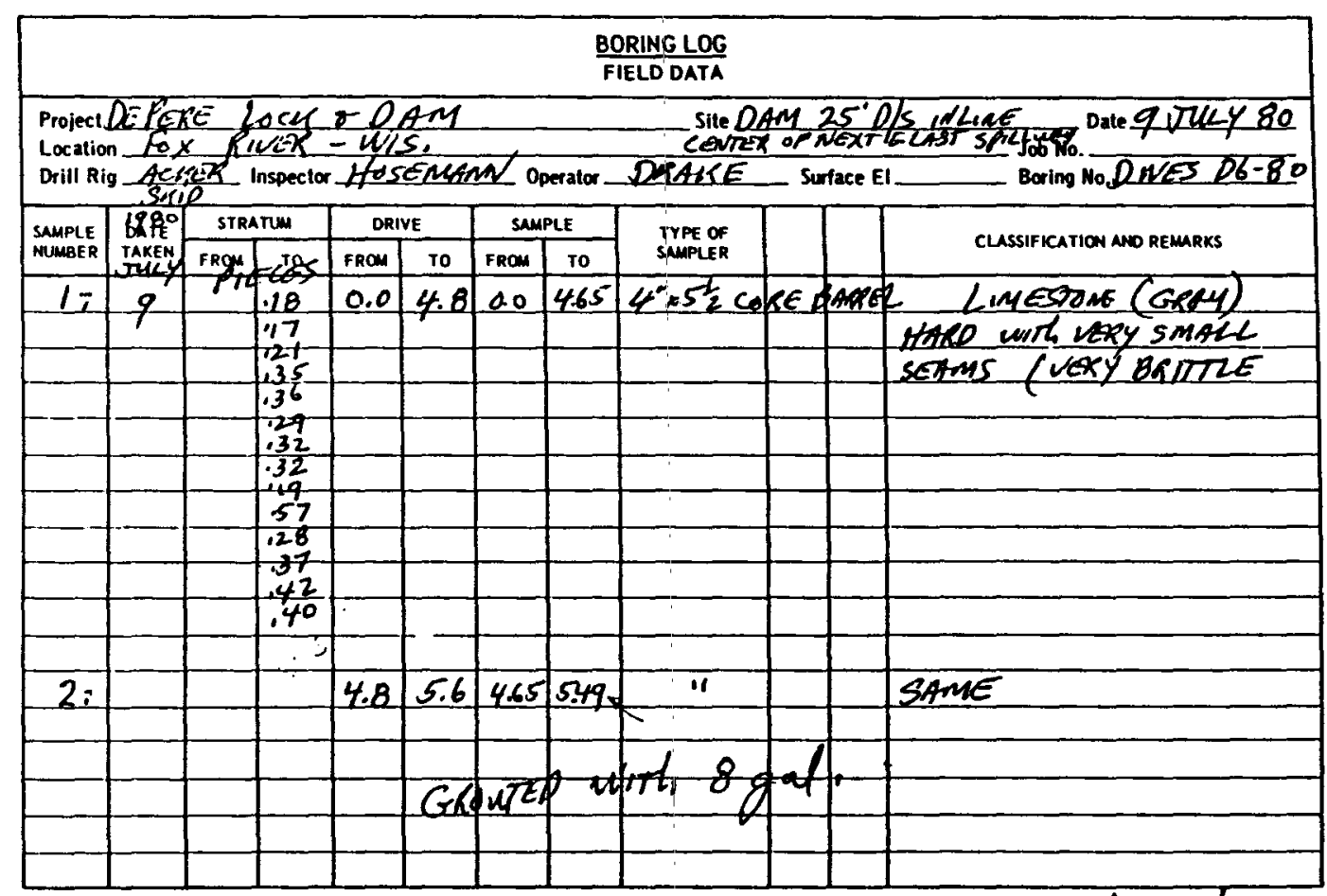

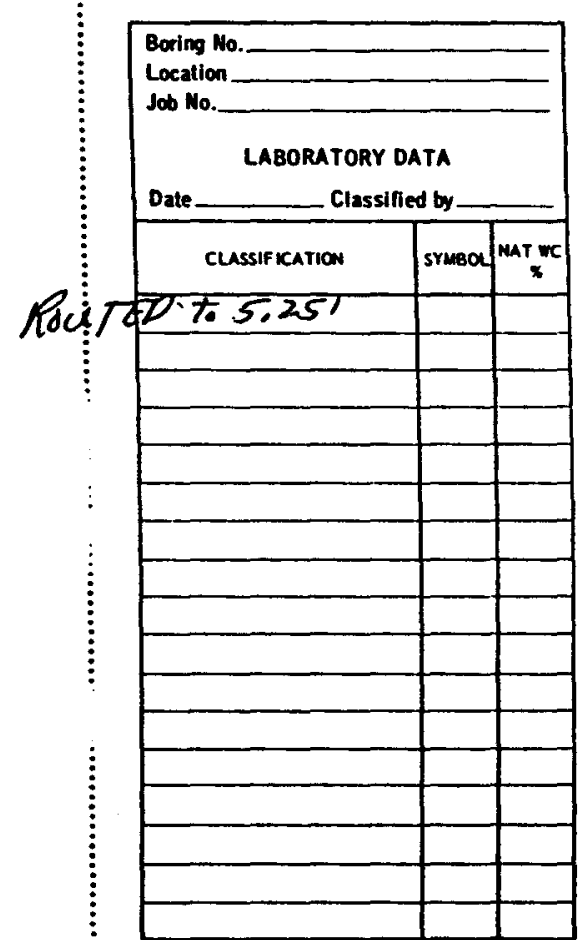

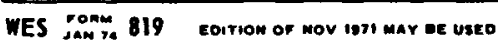


Hole Ho. D WES D7-80

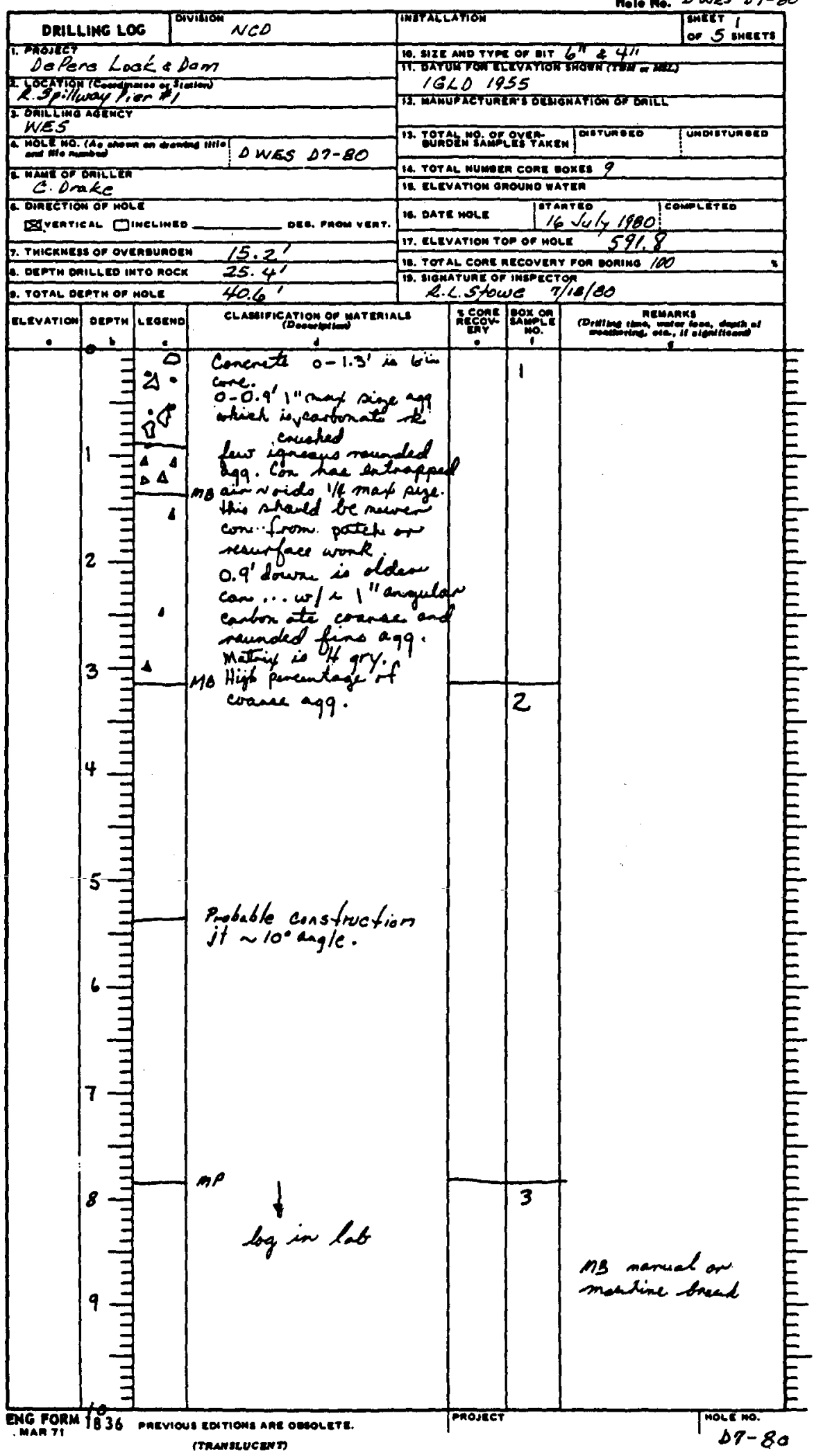


Hole No.

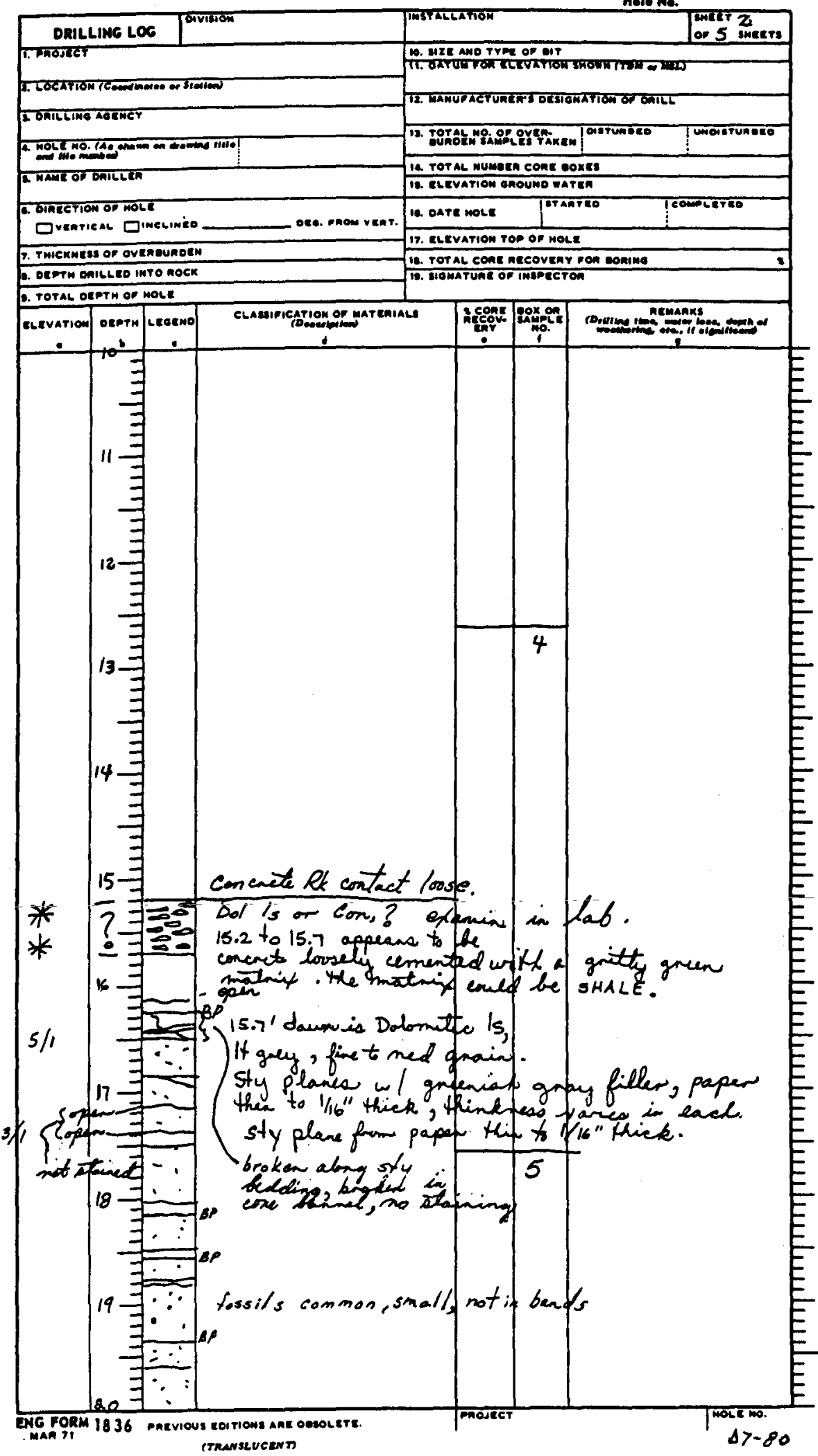




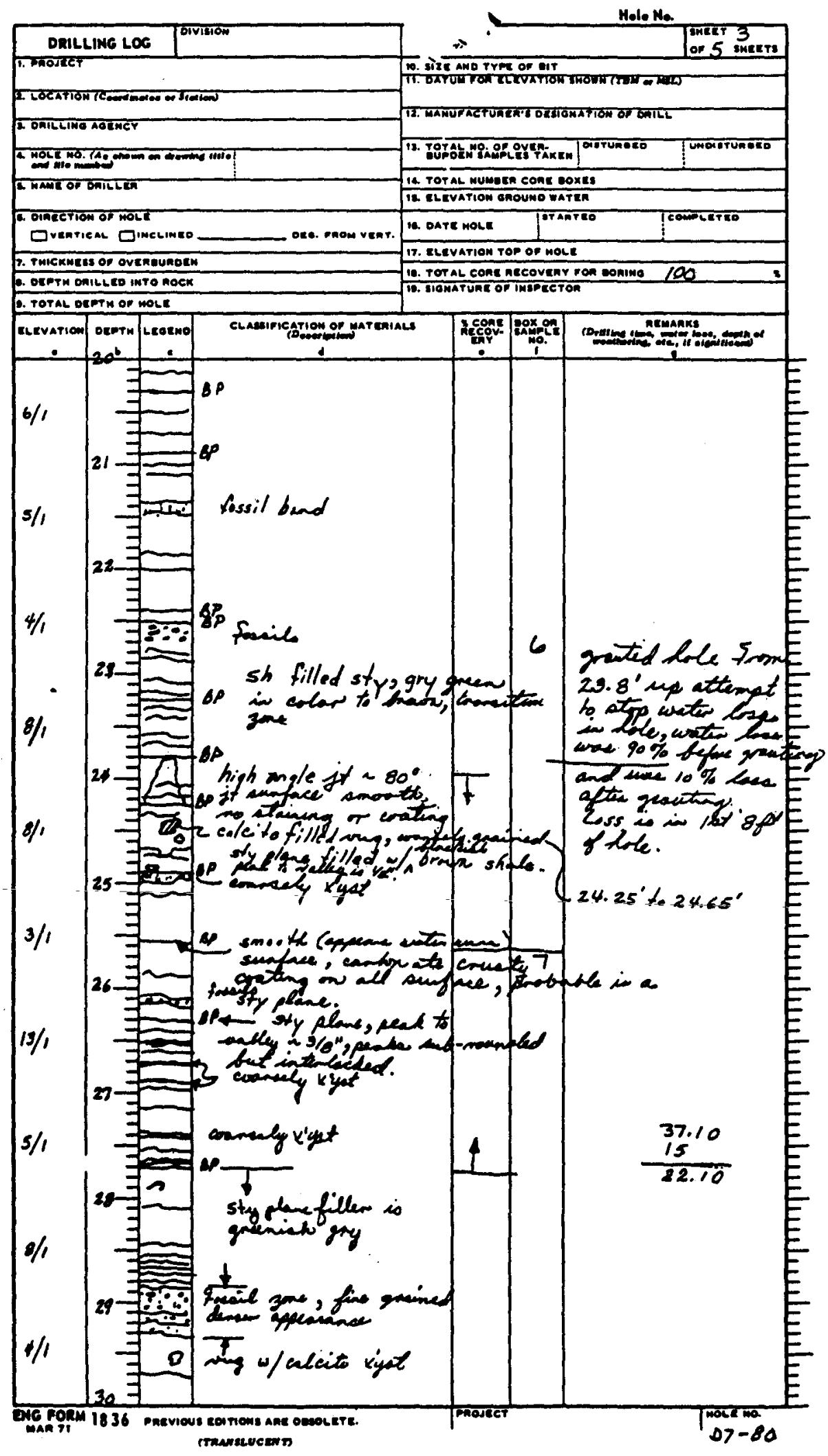


Hele Na.

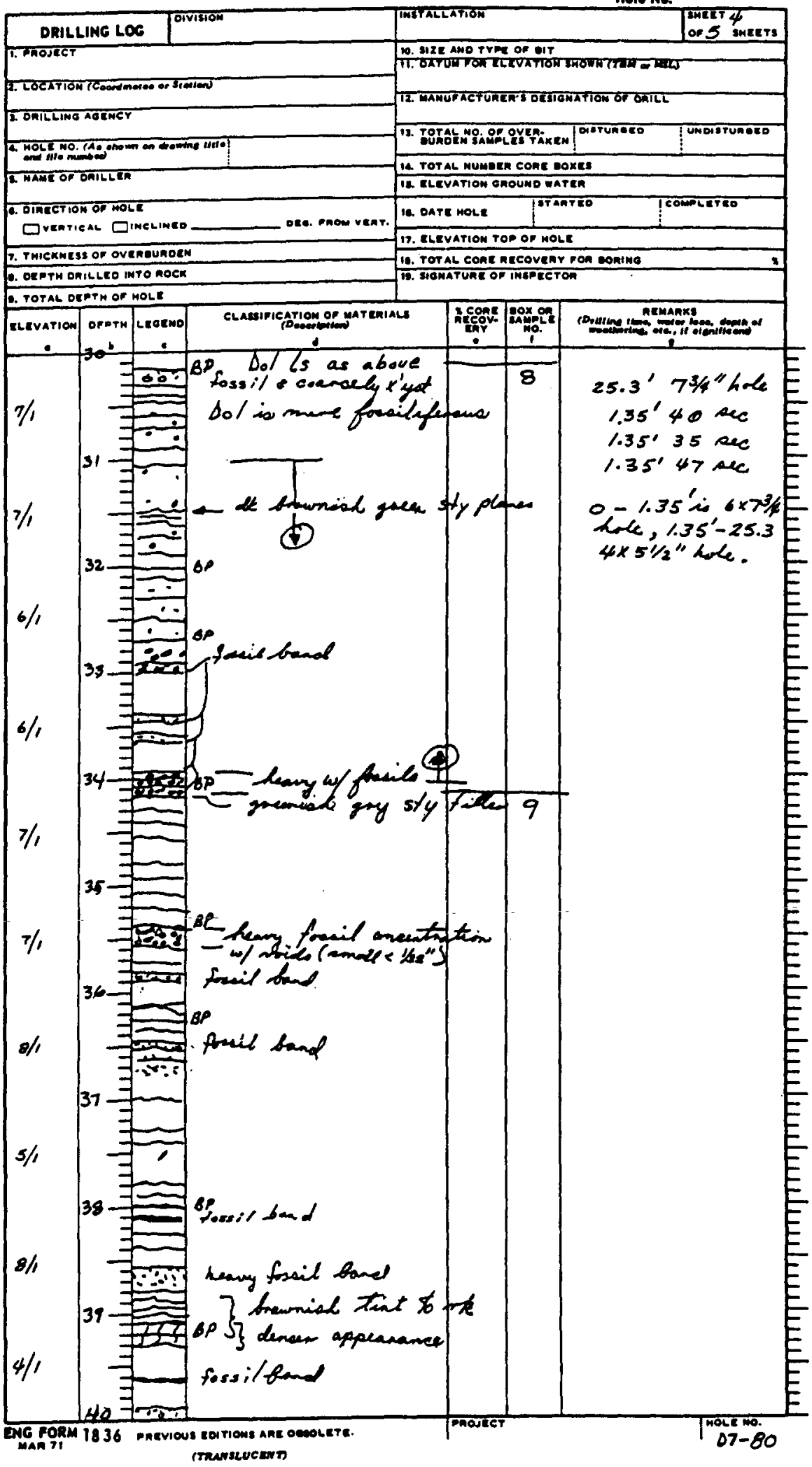




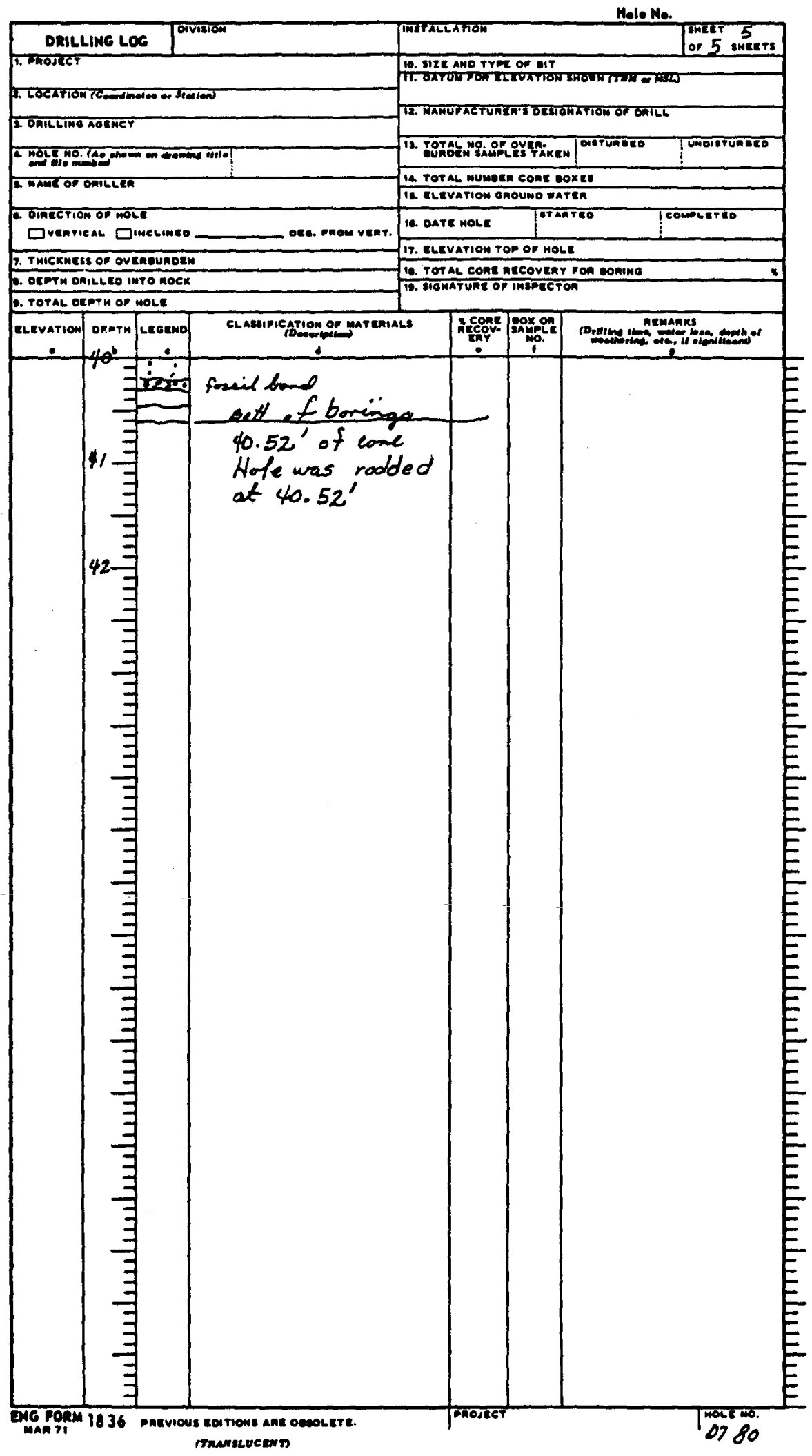


Hale Me. 0 WES 08 .

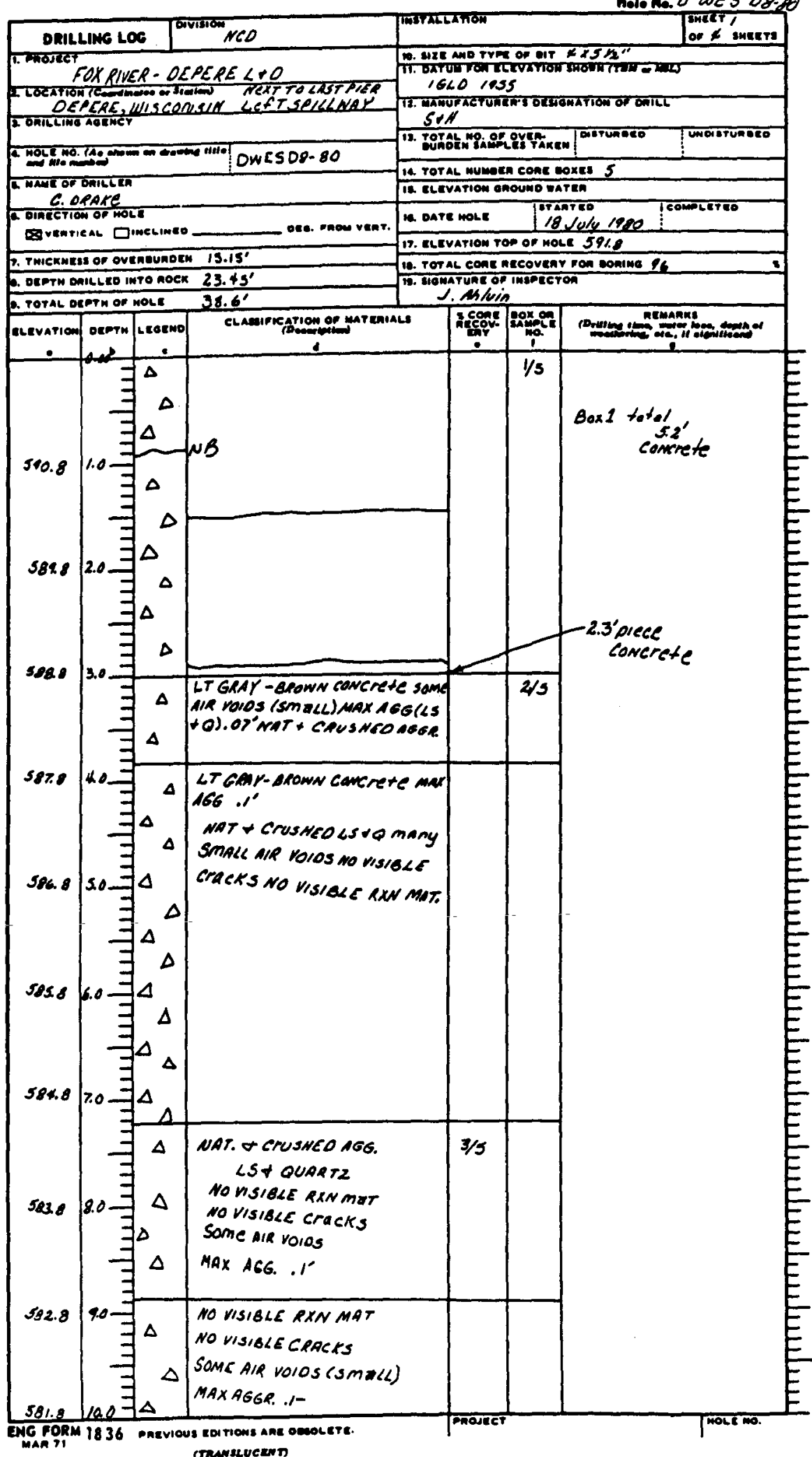

itrunsuceren 
Hele Ne. D WES OS-80

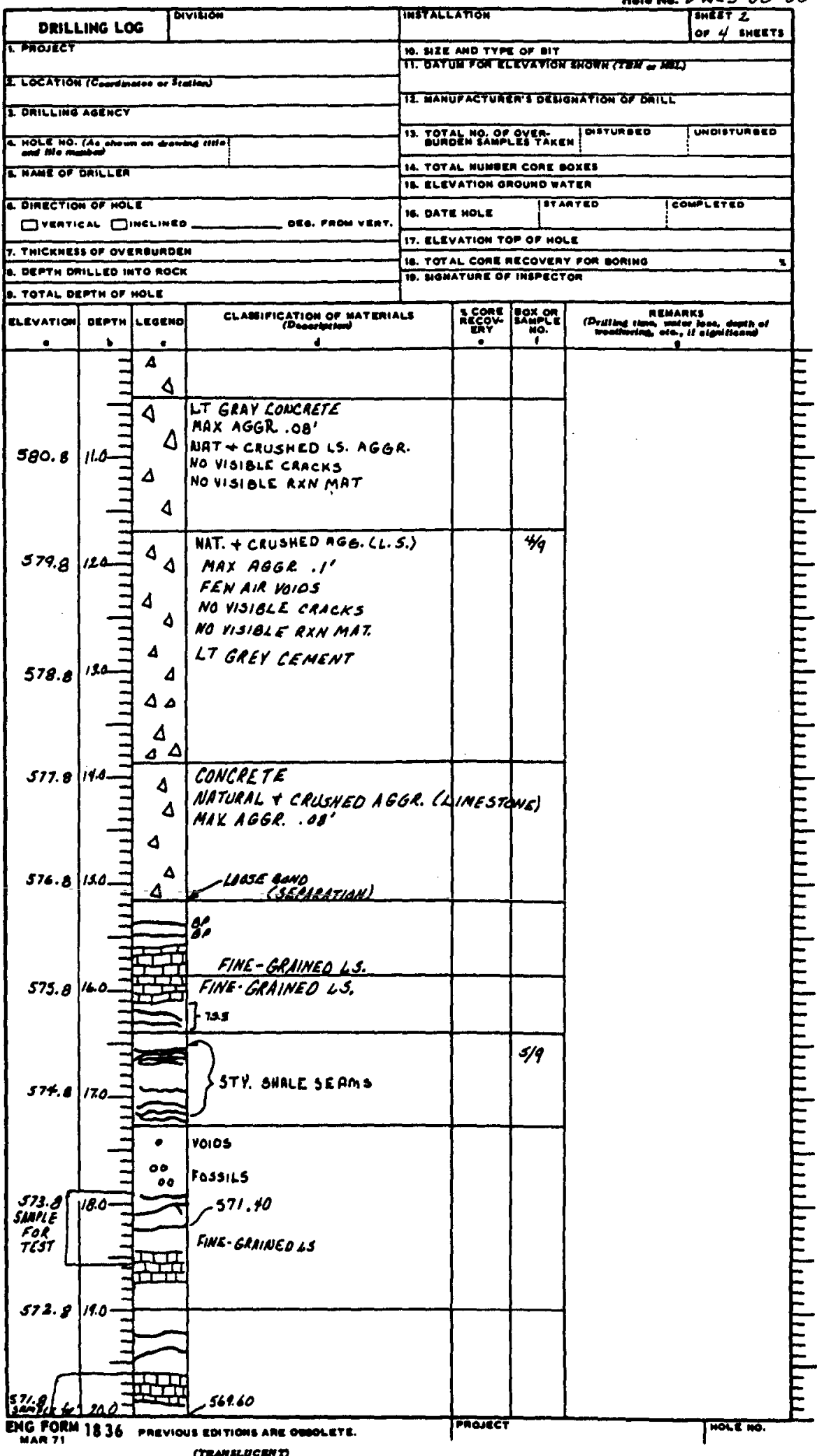


Hole Ne. D WES D B-BO

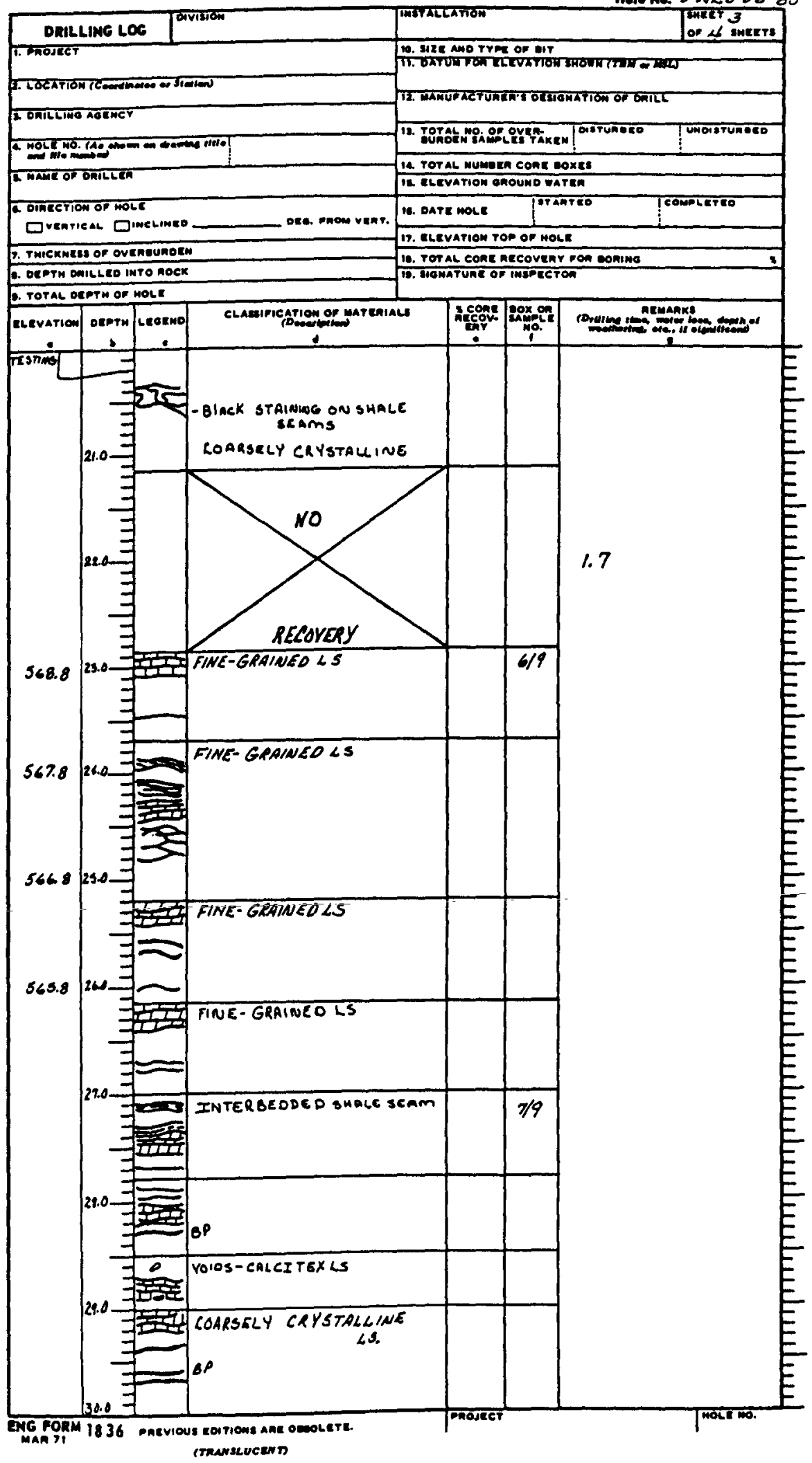


Hele Ne. D K/ES DE-8O

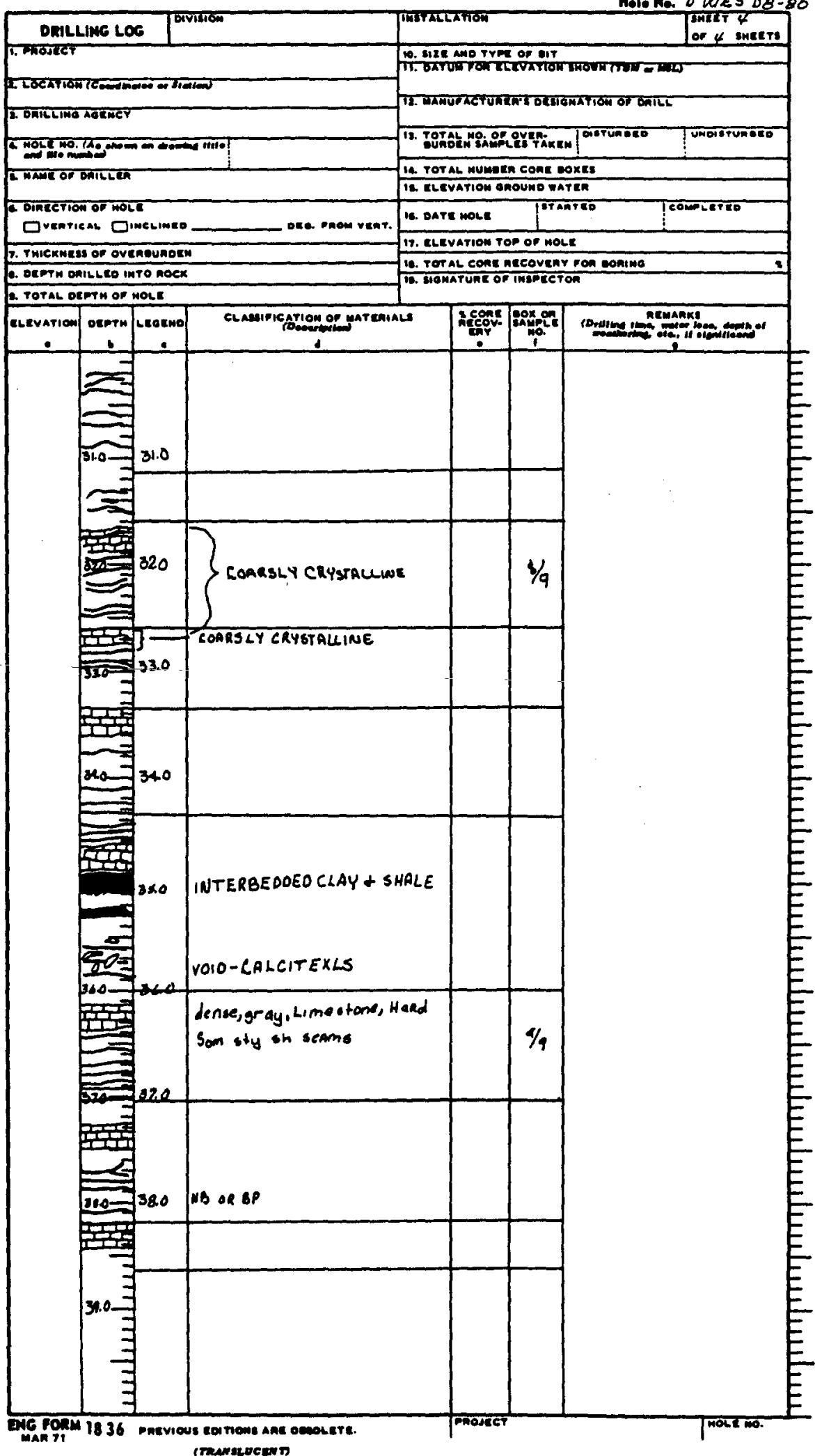




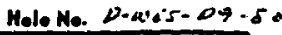

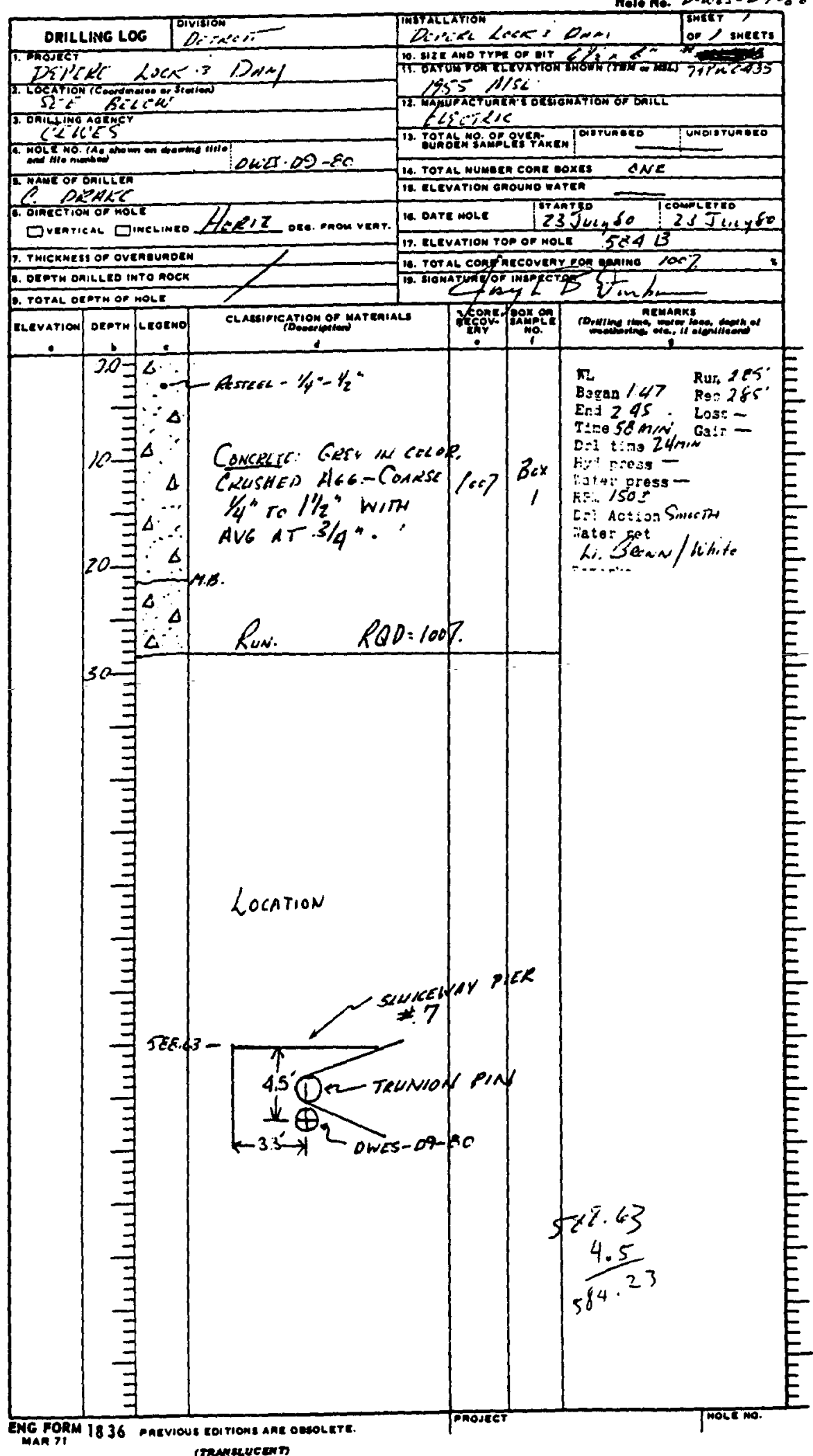

remerucan 
Holo He. Da. 5 - D/O-80

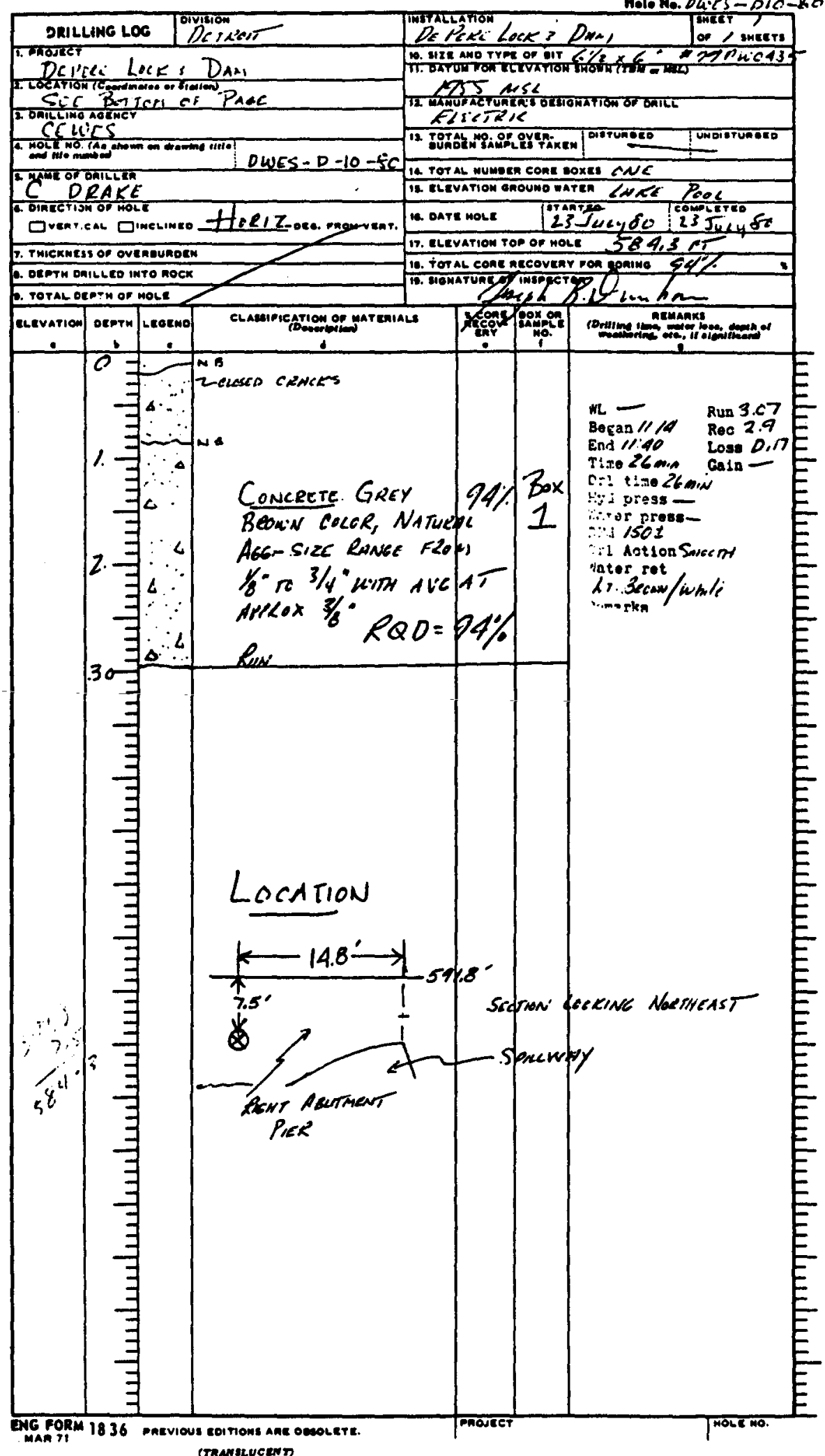


In accordance with letter from DAEN-RDC, DAEN-ASI dated 22 July 1977, Subject: Facsimile Catalog Cards for Laboratory Technical Publications, a facsimile catalog card in Library of Congress MARC format is reproduced below.

Stowe, Richard L.

Condition survey of Depere Lock and Dam Lower Fox

River, Wisconsin / by Richard L. Stowe, Joyce C. AhIvin (Structures Laboratory, U.S. Army Engineer Waterways Experiment Station). -- Vicksburg, Miss. : The Station ; Springfield, Va. : available from NTIS, 1982.

$96 \mathrm{p}$. in various pagings, $26 \mathrm{p}$. of plates; ill.;

$27 \mathrm{~cm}$. -- (Miscellaneous paper ; SL-82-3)

Cover title.

"June 1982."

Final report.

"Prepared for U.S. Army Engineer District, Chicago." Bibliography: p. 29.

1. Concrete dams. 2. Dams--Inspection. 3. DePere Lock and Dam (Wis.) 4. Lower Fox River (Wis.) I. Ahlvin, Joyce C. II. United States. Army. Corps of Engineers. Chicago District. III. U.S. Army Engineer Waterways

Stowe, Richard L.

Condition survey of Depere Lock and Dam Lower Fox : ... 1982.

Experiment Station. Structures Laboratory. IV. Title V. Series: Miscellaneous paper (U.S. Army Engineer Waterways Experiment Station) ; SL-82-3. TA7.W34m no.SL-82-3 